\title{
Essays on Agricultural Technology Adoption, Value Chain Development, and Intra-Household Decision-Making
}

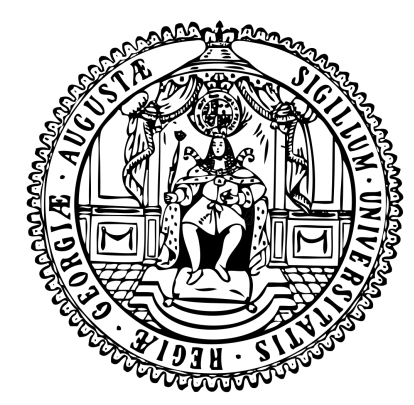

Dissertation

to attain the doctoral degree (Dr. rer. pol.) of the Faculty of Agricultural Sciences Georg-August-Universität Göttingen

\author{
Submitted by \\ Cansin Arslan \\ Born in Bandırma, Turkey
}

Göttingen June 2020 
Supervisor: $\quad$ Prof. Dr. Meike Wollni

Co-Supervisor: $\quad$ Prof. Dr. Matin Qaim

Co-Supervisor: $\quad$ Prof. Dr. Sebastian Vollmer

Date of submission: June 8, 2020

Date of defense: July 15, 2020 


\section{Summary}

While considerable progress has been made over the last 30 years in poverty reduction, about ten percent of the people in the world still live in extreme poverty (World Bank, 2020). It is the field of economics that formulate theories, devise methods, and make empirical analyses that inform policies and practices to reduce poverty and improve welfare in developing countries. This dissertation consists of three essays at the intersection of development and agricultural economics. Each essay has its own introduction, methods, results, and conclusion section. The essays share a common ground in that they are based on primary data collected from smallholder coffee-growing households in eastern Uganda.

Approximately 80 percent of the extreme poor live in rural areas and growth in agriculture sector is found to be more poverty-reducing than other sectors in poorest countries (World Bank, 2007). The first essay of this dissertation relates to commonly identified informational barriers to agricultural technology adoption which is associated with agricultural growth. In particular, the essay explores the role of the communicator of information in agricultural extension by testing the effectiveness of two approaches. In the first approach a peer farmer supports an extension worker whereas in the second approach a high-status market actor supports an extension worker in communicating information to farmers. Results show larger effects on improved harvest practices if the extension worker is supported by a peer farmer and that farmers who receive information both from an extension worker and a market actor participate more in high-value markets. Additionally, we show that harvest quality and participation in high-value markets lead to higher coffee revenues for farmers.

In the second essay, the phenomenon of value-degrading in the coffee value chain is examined. Coffee growing households regularly undertake home-processing of coffee cherries harvested fresh and sell parchment coffee: an activity that is commonly regarded as value-adding. This essay shows that parchment production is, in fact, a value degrading activity that generates a considerable potential profit loss for households selling large amounts of parchment. Our results indicate that efforts for value upgrading through processing of fresh produce in agri-food markets can also generate a value reduction and should integrate relevant characteristics of the value chain, such as quality-assurance. 
The current way in which poverty is measured does not allow for an accurate understanding of individual poverty, as it assumes equal distribution of resources within household members. Yet, the effectiveness of development interventions, such as value chain development and income transfers depend on how household members with differing preferences make decisions regarding household income. In the third essay of this dissertation we study decision-making about resources within the household. In particular, employing the Becker-DeGroot-Marschak (BDM) mechanism, we elicit the willingness of women and men to pay (WTP) to receive a small cash transfer in private (secret from their spouse) instead of in front of their spouse. Our results show that participants are willing to give up on average half of the endowment to receive it in private. Exploring the drivers of WTP, a negative and significant relationship is documented between willingness to hide income and women's empowerment (say in household decisions), frequency of conflict and aggression in the household, and membership in savings groups. Results also suggest that household members may be hiding money to alter resource allocations to their favour and not necessarily in a way that maximises household welfare.

In order to produce these three essays I conducted a field work of 15 months in Uganda. In particular, I implemented two different field experiments, i.e., one randomised controlled trial (RCT) and a separate lab-in-the-field experiment, and collected data through interview-based surveys with smallholder coffee growers in the Mt. Elgon Region of Uganda. In total, I carried out three surveys: one baseline and one follow-up survey for the RCT with around 1600 farmers for the first and second essay, and one additional survey with a sub-sample of 422 of these farmers for the third essay. 


\section{Zusammenfassung}

Obwohl in den letzten 30 Jahren beträchtliche Fortschritte bei der Armutsbekämpfung erzielt wurden, leben immer noch etwa zehn Prozent der Menschen auf der Welt in extremer Armut (World Bank, 2020). Es ist das Feld der Entwicklungsökonomie, das Theorien formuliert, Methoden entwickelt und empirische Analysen durchführt, die Politik und Praktiken zur Verringerung der Armut und zur Verbesserung der Wohlfahrt in Entwicklungsländern beeinflussen. Diese Dissertation besteht aus drei Aufsätzen an der Schnittstelle von Entwicklungs- und Agrarökonomie. Jeder Aufsatz hat eine eigene Einleitung, Methoden, Ergebnisse und Schlussteil. Die Aufsätze haben insofern eine gemeinsame Grundlage, als dass sie auf Primärdaten basieren, die in Kleinbauernhaushalten mit Kaffeeanbau im Osten Ugandas erhoben wurden.

Etwa 80 Prozent der extrem Armen leben in ländlichen Gebieten, und es wurde festgestellt, dass das Wachstum im Agrarsektor stärker armutsmindernd ist als in anderen Sektoren der ärmsten Länder (World Bank, 2007). Der erste Aufsatz dieser Dissertation bezieht sich daher auf identifizierte Informationsbarrieren für die Einführung von Agrartechnologien, die mit dem Wachstum der Landwirtschaft verbunden sind. Insbesondere untersucht der erste Aufsatz die Rolle des Informationsvermittlers bei der landwirtschaftlichen Beratung, indem er die Wirksamkeit von zwei Ansätzen testet. Im ersten Ansatz unterstützt ein Durchschnitts-Landwirt (Peer Farmer) einen Berater bei der Informationsvermittlung an die Landwirte, während im zweiten Ansatz ein hochrangiger Marktakteur diese Aufgabe übernimmt. Die Ergebnisse zeigen einen größeren Effekt auf verbesserte Erntepraktiken, wenn der Berater von einem Peer Farmer unterstützt wird und wenn Bauern, die Informationen sowohl von einem Berater als auch von einem Marktakteur erhalten, mehr an hochwertigen Märkten teilnehmen. Darüber hinaus zeigen wir, dass Erntequalität und Teilnahme an hochwertigen Märkten zu höheren Kaffeeeinnahmen für die Bauern führen.

Im zweiten Aufsatz wird das Phänomen der Wertverminderung in der Wertschöpfungskette von Kaffee untersucht. Kaffee anbauende Haushalte übernehmen regelmäßig die Heimverarbeitung frisch geernteter Kaffeekirschen und verkaufen die geschälten Kaffeebohnen: eine Tätigkeit, die gemeinhin als wertschöpfend angesehen wird. Dieser Aufsatz zeigt, dass es sich bei der Produktion von geschältem Kaffee tatsächlich um eine wertmindernde Tätigkeit handelt, die für Haushalte, die 
große Mengen geschälter Kaffeebohnen verkaufen, einen beträchtlichen potenziellen Gewinnverlust mit sich bringt. Unsere Ergebnisse deuten darauf hin, dass Bemühungen um eine Wertsteigerung durch die Verarbeitung von Frischprodukten auf den Agrar- und Lebensmittelmärkten auch eine Wertminderung bewirken können und relevante Merkmale der Wertschöpfungskette, wie z.B. die Qualitätssicherung, integriert werden sollten.

Die derzeitige Art und Weise, wie Armut gemessen wird, erlaubt kein genaues Verständnis der individuellen Armut, da sie von einer gleichmäßigen Verteilung der Ressourcen innerhalb der Haushaltsmitglieder ausgeht. Dennoch hängt die Wirksamkeit von Entwicklungsmaßnahmen wie der Entwicklung der Wertschöpfungskette und Einkommenstransfers davon ab, wie Haushaltsmitglieder mit unterschiedlichen Präferenzen Entscheidungen über das Haushaltseinkommen treffen. Im dritten Aufsatz dieser Dissertation untersuchen wir die Entscheidungsfindung über Ressourcen innerhalb des Haushalts. Unter Anwendung der Lotterie nach Becker-DeGroot-Marschak (BDM) eruieren wir insbesondere die Zahlungsbereitschaft von Frauen und Männern (WTP), einen kleinen Geldtransfer privat (geheim vor ihrem Ehepartner) statt vor ihrem Ehepartner zu erhalten. Unsere Ergebnisse zeigen, dass die Teilnehmerinnen und Teilnehmer bereit sind, im Durchschnitt auf die Hälfte des Kapitals zu verzichten, um es privat zu erhalten. Bei der Untersuchung der Triebkräfte der WTP wird ein negativer und signifikanter Zusammenhang zwischen der Bereitschaft, Einkommen zu verbergen, und der Stellung der Frauen (z.B. bei Entscheidungen im Haushalt), der Häufigkeit von Konflikten und Gewalt im Haushalt und der Mitgliedschaft in Spargruppen deutlich. Die Ergebnisse deuten auch darauf hin, dass Haushaltsmitglieder möglicherweise Geld verstecken, um die Ressourcenzuteilung zu ihren Gunsten zu verändern, und zwar nicht unbedingt in einer Weise, die das Wohlergehen des Haushalts maximiert. 


\section{Acknowledgements}

I have written this dissertation as part of the Research Training Group (RTG) GlobalFood at the University of Göttingen. I gratefully acknowledge the financial support to this research provided by the German Research Foundation (DFG) through grant RTG1666. This research has also been part of a broader research project called Value Chain Innovation Platforms for Food Security in Eastern Africa (VIP4FS) implemented by the World Agroforestry Center (ICRAF). Financial support from the Australian Centre for International Agricultural Research (ACIAR) and the CGIAR Research Program on Forests, Trees and Agroforestry (FTA) is gratefully acknowledged.

There are many people who have played a considerable role in making this dissertation possible in different ways-I am thankful to all of them. First of all, my supervisor Meike Wollni, I cannot thank you enough for having guided me throughout this Ph.D. program. Thank you for having fully trusted me and given me the liberty to pursue my own research interests. Thank you for having allowed me to stay in the field long enough to conduct my research in the best way possible and collaborate with other researchers making me grow into an independent researcher. Our meetings were always very motivating and encouraging. Your realism blended with optimism have kept my hope and spirit up to this day. With your sheer humility and kindness, you are a true role model.

Secondly, I am indebted to my co-supervisor Matin Qaim. I am honoured to have a researcher of your caliber in my committee. Your feedback so considerably improved this dissertation. Thank you also for supporting my career as a researcher. The interest and support you have for the juniors of GlobalFood have made this Ph.D. program an extraordinary one. Without you, this unforgettable journey would not have been possible in the first place.

Thirdly, I am grateful to Sebastian Vollmer for his advice and support as a member of my committee. You have not only provided feedback on my research but coordinated opportunities for my research career. I would also like to thank Bernhard Brümmer, Marcela Ibanez, and also Raphael Brade for their very useful feedback which substantially improved this dissertation.

Melanie Grosse deserves a big thanks for her continuous efforts to make this Ph.D. program better. Thank you Katrin Pape, Ann-Kathrin Fahlbusch, Jessica Torluccio, and Gönül Yıldırım for having enabled me to conduct my research in the most efficient way possible. 
The ICRAF team, Judith Oduol and Karl Hughes, thank you for having had me on board with the VIP4FS project, having trusted me with the fieldwork, and supported and guided me whenever I reached for help.

The Adelaide team, I feel very fortunate to have met you. You truly changed the course of my Ph.D. My fieldwork would not have been as good and fun without you. I will be missing the enriching conversations we had in Kapchorwa. You are like a family to me. Randy Stringer, I cannot thank you enough for having coordinated funds, and saved the data collection and the intervention, and for your guidance in tricky situations. Daniel Gregg, you have been an amazing mentor and a co-author. This dissertation benefited greatly from your input and I learned a whole lot from you. Adam Marley, thank you for having taught me so much about coffee and for your companionship in Uganda.

Additionally, I am truly grateful to Seyhun Orcan Sakallı, Farshad Ranjbar Ravasan, Philippe Machover, Denis Cogneau, Karen Macours, and Luc Behaghel whom I learned a lot from in Paris about economic theory, econometrics, empirical analysis, development economics, and fieldwork.

I am also indebted to Daniel Oryem and the Kawacom extension workers in Kapchorwa for their patient cooperation throughout the intervention. Thank you, Clement Okia, Prossy Isubikalu, Francis Ngewa, Leonard Ekoot, and Innocent Tuhaise for having supported the intervention and Filder Aryemo, Jacob Ocen, Wilson Mudebo, Julius Njoke and the field assistants for having made the data collections possible. I would also like to express my sincere gratitude to all the farmers interviewed for this research. This research would not have been possible without you.

Juliana Ewert, you made the Uganda experience so much better by being there whenever I needed and having dragged me to different places for a change in mood. You and our days in Kampala will continue to be missed.

My friends at GlobalFood, you will also be missed. Aspasia Werner, you always manage to put a smile on my face. Thanks for your true friendship in good and bad days. Dela-Dem Doe Fiankor, thank you for having been there for me whenever I needed since the first months of this Ph.D. Ayobami Adetoyinbo, it has been a pleasure to share the office with you. Thanks for always helping me out, and for the comfort and productive office environment you have offered. Christina Martini, Nina Grassnick, Lisa Jaeckering and Sarah Iweala, thank you for having made the time for a (personal) chat. 
Viviana Uruena, thank you for always being there to share my desperation and joy and doing that no matter which part of the world we are, including in Africa. I am grateful for the brilliant research discussions and the feedback you have given on the papers, the lovely days we spent working in cafés in Göttingen, and the wonderful (and extended) dinner-table conversations we had. I feel very fortunate to have you around.

My special thanks go to Tobias Haar who has made my life so much better and happier during the stressful times of this Ph.D. I can never thank you enough for your efforts to ensure a perfect working environment handling technical issues and taking over all household tasks towards the end. Thank you for your unconditional love, unwavering support, and the understanding and patience you have for me. I am blessed to have a wonderful person like you in my life.

My life-long friends from Turkey who never stopped supporting me, I owe you big time. Gözde Özel, thank you for making the effort to video call me every week which you continued even when I was in rural Uganda. Thank you for laughing and crying with me and doing all that from the bottom of your heart. Thank you, Gamze Engüdar for your constant support over the years and keeping my spirit up in stressful times. Ayçin Civan, Yasemin Ilhan, Murat Karakaş, and Bilinç Sezgin thanks for sharing my desperation and joy whenever I reach out to you. Thank you, Ilayda Sanağ and Oğuz Demir, for always making me feel your support. Hepinizi sevgiyle kucaklıyorum.

En büyük teşekkürü ise elbette ki beni, koşulsuz sevgi, saygı ve sabırla büyütüp bu günlere getiren aileme ediyorum. Beni, özgür, bağımsız ve kendine güvenen bir birey olarak yetiştiren; bununla beraber beni maddi ve manevi hep destekleyen; zor günlerde hiçbir şeyin benden daha önemli olmadığını sıkça hatırlatan annem Ülker Arslan ve babam Mustafa Arslan, size minnettarım. Sevgili ablalarım Senem Arslan ve Gizem Arslan, maddi ve manevi olarak beni hep desteklediğiniz, benimle birlikte gülüp ağladığınız, beni dinlediğiniz, anladığınız, herkesten koruduğunuz ve hep benim tarafımda olduğunuzu hissettirdiğiniz için çok teşekkür ederim. Bu aileye doğmak, hayattaki en büyük şansım kuşkusuz. Sizleri çok seviyorum. 
"Most of the people in the world are poor, so if we knew the economics of being poor, we would know much of the economics that really matters. Most of the world's poor people earn their living from agriculture, so if we knew the economics of agriculture, we would know much of the economics of being poor."

- Theodore W. Schultz, 1979

"Poverty is not just a lack of money it is not having the capability to realise one's full potential as a human being."

- Amartya Sen, 1999

To the people of the world who have failed to realise their full potential because of where or to whom they were born 


\section{Contents}

Summary $\quad$ i

$\begin{array}{lll}\text { Acknowledgements } & \text { v }\end{array}$

1 Introduction $\quad 1$

1.1 Agriculture for development . . . . . . . . . . . . . . . . . 1

1.2 Overview of essays . . . . . . . . . . . . . 4

1.3 Study background $\ldots \ldots \ldots \ldots$

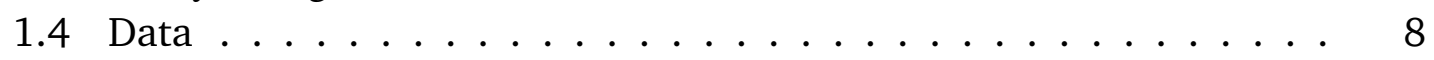

1.5 Roadmap ...................... 8

2 Who communicates the information influences what technology is adopted: $\begin{array}{lr}\text { evidence from Uganda } & 9\end{array}$

2.1 Introduction . . . . . . . . . . . . . . . . . 10

2.2 Study context . . . . . . . . . . . . . . . . . . . 15

2.3 Conceptual framework . . . . . . . . . . . . . . . . . 17

2.4 Experimental design . . . . . . . . . . . . . . . . 19

2.4 .1 Treatments ................... 20

2.5 Data and estimation strategy . . . . . . . . . . . . 22

2.5 .1 Data ......................... 22

2.5 .2 Estimation strategy . . . . . . . . . . . . . 27

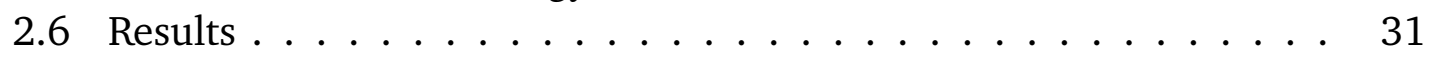

2.6.1 Information provision treatment .......... 31

2.6.2 Effects of the peer farmer treatment . . . . . . . . . 34

2.6.3 Effects of the market actor treatment . . . . . . . . . 36

2.6.4 Do quality and high-value market participation explain revenues? . . . . . . . . . . . . . . . . 44 41

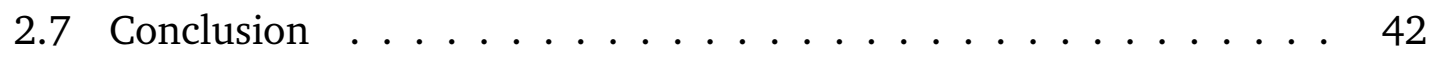

2.8 Additional tables . . . . . . . . . . . . . . . . 44

3 Paying more to make less: value degrading in the coffee value chain in $\begin{array}{ll}\text { eastern Uganda } & 49\end{array}$

3.1 Introduction . . . . . . . . . . . . . . . . 50

3.2 Context: Fresh Cherry and Parchment Markets . . . . . . . . . . . 54

3.3 Identification and Estimation Strategy . . . . . . . . . . 56

3.3.1 Estimating the effect of parchment production on revenues and profits ...................... 56

3.3.2 Estimating drivers of parchment production . . . . . . . 58

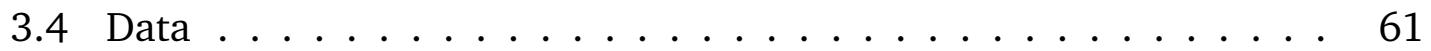

3.4 .1 Summary Statistics . . . . . . . . . . . . . . . 63

3.5 Results . . . . . . . . . . . . . . . . . . 64 
3.5.1 Revenues and profits per kilogram . . . . . . . . . . 64

3.5.2 Drivers of parchment production . . . . . . . . . 67

3.6 Conclusion . . . . . . . . . . . . . . . . . 71

3.7 Additional figures and tables . . . . . . . . . . . . . . . 74

4 Inefficiency in the household: a gendered analysis of willingness to pay to hide income from spouses in rural Uganda 81

4.1 Introduction . . . . . . . . . . . . . . . 82

4.2 Review of theories and evidence on household behaviour . . . . . . 85

4.3 Experimental Method and Procedures . . . . . . . . . . . . 88

4.3.1 The Becker-DeGroot-Marschak (BDM) mechanism . . . . . 88

4.3.2 Experimental design and procedures . . . . . . . . . . . 90

4.4 Data and Descriptive Statistics . . . . . . . . . . . . . . . . . 92

4.4 .1 Data . . . . . . . . . . . . . . . . . . 92

4.4.2 Descriptive Statistics . . . . . . . . . . . . . . . . . . 95

4.5 Estimation Strategy . . . . . . . . . . . . . . . . . . 96 96

4.5.1 Assessing willingness to pay to hide income . . . . . . . 96

4.5.2 Estimating the effect of private rewards on private and house-

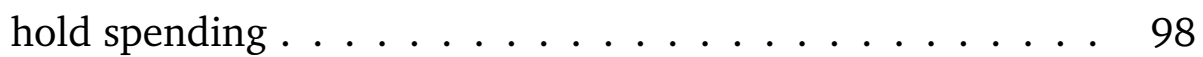

4.6 Results . . . . . . . . . . . . . . . . . . . . . . 999

4.6.1 Willingness to pay (WTP) to hide income . . . . . . . . 99

4.6.2 Drivers of WTP to hide income . . . . . . . . . . . 100

4.6.3 Private versus household consumption . . . . . . . . . . 103

4.7 Conclusion . . . . . . . . . . . . . . . . . . . . 107

4.8 Additional Figures and Tables . . . . . . . . . . . . . . . 109

5 Conclusion 116

5.1 Synopsis of findings and the ensuing policy implications . . . . . 116

5.2 Limitations and scope for further research . . . . . . . . . 120

$\begin{array}{ll}\text { Appendices } & 123\end{array}$

Appendix A Who communicates the information influences what technology is adopted 123

A.1 Harvest Quality Score . . . . . . . . . . . . . . . . . . . 123

Appendix B Paying more to make less: value degrading in the coffee value chain in eastern Uganda

Appendix C Inefficiency in the household: a gendered analysis of willingness to pay to hide income from spouses in rural Uganda 


\section{List of Figures}

1.1 The Mount Elgon region in eastern Uganda $\ldots . . . . . . .77$

2.1 Treatment status of the households in our sample . . . . . . . . 23

2.2 High-value market participation (\%) before and after the intervention 30

2.3 Revenues earned per $\mathrm{kg}$ in UShs before and after intervention . . . 31

3.1 Distribution of share of cherries taken up by parchment (\%) . . . . 60

3.2 Households in our sample across production categories . . . . . . . 74

3.3 Products and activities in the (washed) Arabica coffee value chain . 75

4.1 Distribution of stated WTP across genders . . . . . . . . . . . 100

4.2 Distribution of stated WTP across rewards offered . . . . . . . . . . 100

4.3 Treatment status of the households in our sample . . . . . . . . . . 109 


\section{List of Tables}

2.1 Compliance with random assignment . . . . . . . . . . . . . . 20

2.2 Attrition between baseline and follow-up surveys . . . . . . . . . . 23

2.3 Pre-intervention balance . . . . . . . . . . . . . 26

2.4 Effects on harvest quality scores, high-value market participation, and revenues earned per $\mathrm{kg}$ (average prices) . . . . . . . . . 33

2.5 Effects of peer farmer treatment (T2) against T1 . . . . . . . . . . 35

2.6 Effects of high-status market actor treatment (T3) against T1 . . . 37

2.7 Effects of high-status market actor treatment (T3) against peer farmer treatment $(\mathrm{T} 2) \ldots \ldots \ldots \ldots \ldots$

2.8 Effect of market actor treatment (T3) on perceptions towards the exporter .................... . . 40

2.9 First-difference (FD) estimations . . . . . . . . . . . . . . 42

2.10 Treatment effects on harvest quality scores, high-value market participation, and revenues earned per kilogram . . . . . . . . . . 45

2.11 Effects on harvest quality scores (full specification) . . . . . . . . 46

2.12 Effects on high-value market participation (full specification) . . . 47

2.13 Effects on revenues per kilogram (full specifiation) . . . . . . . 48

3.1 Sample characteristics across producer categories . . . . . . . . . 64

3.2 Revenues and profits per $\mathrm{kg}$ explained by participation in parchment production ................. 65

3.3 Revenues and profits per kilogramme explained by the extent of parchment production ............... 66

3.4 Participation in parchment production. First-stage probit estimations 68

3.5 Second-stage coefficients and marginal effects estimated with truncated normal model . . . . . . . . . . . . . . . . . 69

3.6 Coffee revenues per $\mathrm{kg}$ (UShs). Full Specification . . . . . . . . . 76

3.7 Coffee profits per kg (UShs). Full Specification _ . . . . . . . . 77

3.8 Descriptive Statistics . . . . . . . . . . . . . . . . . 78

3.9 First stage of IV estimations _ . . . . . . . . . . . . . . 78

3.10 Stated reasons for parchment production . . . . . . . . . . . 78

3.11 Stated reasons for parchment production. Marginal effects. Probit estimations . . . . . . . . . . . . . . . . 79

3.12 Second-stage coefficients estimated with different models . . . . 80

4.1 Characteristics of male and female participants . . . . . . . . 96

4.2 Characteristics of participants who received the reward privately and publicly . . . . . . . . . . . . . . . . 97

4.3 WTP to keep income private . . . . . . . . . . . . . . . . . . . . . . . . 101

4.4 Drivers of WTP to keep income private . . . . . . . . . . . . . 102 
4.5 Intended and actual private versus household spending on female and male subsamples . . . . . . . . . . . . . . . . . . . . 104

4.6 Intended and actual private versus household spending on subsamples of high and low rewards offered . . . . . . . . . . . . 106

4.7 Private and public spending across genders and rewards received . 110

4.8 WTP values across genders, rewards offered and rewards received . 111

4.9 Drivers of WTP to keep income private (Full Specification) . . . . . 112

4.10 Intended and actual private versus household spending on female and male subsamples (restricted sample) . . . . . . . . . . . 113

4.11 Intended and actual private versus household spending on highand low-reward subsamples (restricted sample) . . . . . . . . . 114

4.12 Multicollinearity analysis for the model used to estimate drivers of WTP .......................... 115

4.13 Correlation between the items in the aggression index . . . . . . 115 


\section{Chapter 1}

\section{Introduction}

This dissertation comprises three essays at the intersection of development and agricultural economics. Each essay has its own introduction, methods, results, and conclusion section. The essays herein touch upon a wide variety of topics including information constraints in technology adoption, agricultural extension, high-value market participation, profitability of upgrading, quality uncertainty, asymmetric information, efficiency of household decision-making, and intra-household resource allocation. They share a common ground in that they are based on primary data collected from smallholder coffee-growing households in eastern Uganda. In what follows, I provide a general framework for the research objectives of this dissertation and a brief overview of the essays herein.

\subsection{Agriculture for development}

Whilst considerable progress has been made over the last 30 years in poverty reduction, more than 700 million people still live in extreme poverty (World Bank, 2020). Approximately 80 percent of the extreme poor live in rural areas and roughly 20 percent of rural inhabitants in developing countries live in extreme poverty (Campos et al., 2018). More than half of the world's extreme poor live in sub-Saharan Africa where the agriculture sector accounts for roughly one-third of the economic activity (World Bank, 2007). Growth in agriculture sector is found to be four times more effective in reducing poverty than growth in other sectors in poorest countries highlighting the centrality of agriculture sector to poverty reduction (World Bank, 2007).

The World Development Report Agriculture for Development's main message was that poorest countries should invest more in agriculture to utilise its potential for growth and poverty reduction. A growth strategy with a prominent role for agriculture has been advocated by several prominent economists. For instance, Stiglitz (2018) argues that agriculture will continue to provide the most important basis of employment and income for most developing countries, but it should be transformed. This transformation encompasses better (non-labour-saving) tech- 
nologies, such as improved seeds, fertilisers, and better agricultural practices. In some cases, there are ample opportunities for increasing exports of agricultural goods and the transformation should identify high-value crops for which there is a demand elsewhere. Such transformation of agriculture from traditional to modern can potentially improve food security and lead to productivity, employment, and income growth. Overall, the main lesson is that agricultural growth should be seen as an essential prong in the multi-pronged approach to economic growth and development in poor countries.

However, the desirable transformation of agriculture in poor regions has been hampered by factors that are presumed to originate in market and government failures (World Bank, 2007; Goyal and Nash, 2017; De Janvry and Sadoulet, 2019). Such failures may present themselves as a lack of profitability of technologies, a lack of local availability of the potentially profitable technologies, and constraints to adoption of potentially profitable and available technologies. These constraints to adoption of profitable technologies include, among other things, a lack of access to information about a new technology, and lack of access to input and output markets due to high transaction costs such as poor infrastructure and monopoly power (De Janvry and Sadoulet, 2019). The transformation of the agricultural sector is thus multidimensional and an immense endeavour.

De Janvry and Sadoulet (2019) classify approaches to transformation of agriculture into two groups of which both aim to reach the desired outcomes of adoption of improved technologies, modernization, productivity growth, rural transformation, economic growth and poverty reduction in due course. The first approach is called "constraint removal" which comprises addressing each of the constrains over transformations in their own specific forms for the targeted agents (e.g. farmers). It essentially relies on ensuring the profitability and availability of technologies leading to transformation and overcoming the major barriers to adoption such as information, liquidity, and market access in a particular context (Jack, 2013; Magruder, 2018; Bridle et al., 2020).

The second approach to agricultural transformation is called "inclusive value chain development", wherein incentives are created for smallholders to modernise their production by building value chains for a particular product, and often managing vertical (e.g. contracts) and horizontal (e.g. producer organisations) coordination within the value chains. In some cases, however, the distinction between the two approaches may not be clear. In particular, the second approach may encompass the key element of the first approach i.e. constraint removal addressing the 
constraints to inclusion and competitiveness of smallholder producers within the value chain.

The first essay of this dissertation can be thought of taking the first approach aiming to remove the informational constraints on adoption of quality-enhancing technologies and high-value market participation. In particular, it seeks to understand the role of communicator of the information in addressing informational barriers to adoption of transformative technologies. However, it also satisfies the inclusive value chain development approach characteristics since removing qualityand market-related information barriers are part of the value chain development efforts to increase the value-added of the product and participation of smallholder farmers in high-value markets.

Inclusive value chain development has been strongly supported by the World Bank and institutions alike as a pro-poor agricultural growth strategy in the past decade. In the case for agri-food products, value chain development is usually based on upgrading of particular products or processes so that primary producers capture more value within the supply chain. Upgrading relies on the assumption that there is a progressive movement from a low-value product to a processed, higher-value product and that producers who upgrade capture greater value. The second essay of this dissertation demonstrates a case where upgrading may not be profitable for smallholder farmers in presence of a "market for lemons" in the vein of Akerlof (1970).

Whilst value chain development may be an effective strategy for poverty reduction in developing countries, its effects on poverty depends largely on how resources are allocated within the households. The current way in which poverty is measured does not allow for an accurate understanding of individual poverty, as it disregards the distribution of resources within household members. For instance, Deere and Doss (2006) demonstrate that gender inequalities, particularly in rural areas, are widespread in terms of asset and livestock ownership, land rights, labour, and education among others. Value chain development activities and other interventions such as cash transfers and financial inclusion programs are pro-poor growth strategies and aim at lifting people out of poverty. Higher household income generated as a result of these efforts is expected to be invested in profitable economic activities, and health and education allowing poor households to eventually escape poverty traps. However, how household resources are spent determined by household dynamics to a large extent. Particularly in the context of differing preferences and non-cooperation between the male and female household 
heads, resources may not be utilised in an optimal way. The third essay focuses on the aspect of household decision-making about resources and the factors which may affect household behaviour and poverty reduction efforts.

\subsection{Overview of essays}

This dissertation attempts to contribute to the broad agenda of agriculture for development. The first essay (joint work with Meike Wollni, Judith Oduol, and Karl Hughes) is concerned with understanding and overcoming the problems that hold back transformation of the small farm sector in developing countries. Information is identified as an impediment to adoption of welfare-improving practices in developing countries. Information can be communicated to farmers through traditional extension services which account for a considerable share of government expenditures on agriculture (Akroyd and Smith, 2007). The evidence on the effectiveness of these extension services is, however, inconclusive (Birkhaeuser et al., 1991; Gautam, 2000; Krishnan and Patnam, 2014). Hence, there is a need for developing complementary extension approaches or modalities that are effective in overcoming the informational barriers to adoption of potentially welfare-improving practices.

This essay seeks to understand the role of communicator of the information in addressing informational barriers by testing the effectiveness of two approaches to information delivery. In the first approach a peer farmer supports an extension worker whereas in the second approach a high-status market actor supports an extension worker in communicating information to farmers and our aim is to document relative effects compared to the traditional information delivery by an extension worker. Results show larger effects on improved harvest practices if the extension worker is supported by a peer farmer and that farmers who receive information both from an extension worker and a market actor participate more in high-value markets. Documenting the role of different communicators in information provision to smallholder farmers, this essay represents an important contribution to the literature that identifies information as an impediment to agricultural technology adoption. We also contribute to the literature that documents income effects of high-value market participation and draw lessons for policy makers on addressing informational inefficiencies in a comprehensive way i.e. about both product quality and high-value market participation which together lead to higher revenues (as inclusive value chain development approach suggests).

The second essay of this dissertation (joint work with Daniel Gregg and Meike 
Wollni) falls broadly under value chain development literature. In particular, it is concerned with understanding the effects of upgrading through processing in the coffee value chain in eastern Uganda, but in the presence of quality uncertainty and asymmetric information. Our hypothesis that upgrading through processing is unprofitable is based on the concept of Akerlof's (1970) "market for lemons" wherein the quality and prices of the products traded tend to go down under quality uncertainty and asymmetric information. Coffee growing households regularly undertake home-processing of coffee cherries harvested fresh and sell parchment coffee as a value-adding activity. We show that parchment production is, in fact, a value degrading activity involving both higher costs and lower revenues and generates a considerable potential profit loss for households selling large amounts of parchment. Taking an exploratory approach, we show that coffee quality is a major factor driving parchment production. Growers with lower-quality farms, such as those from lower altitudes and affected by pest and diseases, engage with parchment production to larger extent. Similarly, hiring labour for harvesting (pickers are typically paid based on quantity and not quality of the coffee harvested) is positively associated with parchment production. Among other things, our results indicate that efforts for value upgrading through processing of fresh produce in agri-food markets can also generate a value reduction under quality uncertainty. As a result, efforts for value chain development through upgrading, aimed at improving household welfare in developing countries, should be integrated with relevant characteristics of the supply chain, such as quality-assurance.

In addition to market inefficiencies outlined above, numerous other factors may impede welfare improvements for the poor. Development interventions, such as value chain development activities and cash transfers, are made with the expectation that, with the higher household income, poor households can progressively engage with more profitable agricultural activities as well as invest in nutrition, health, and education breaking the vicious cycle of poverty. However, effectiveness of such policies and interventions depend largely on the inner workings of the household. Particularly in the context of differing preferences and noncooperation between the male and female household heads, resources may not be utilised optimally. The third essay (joint work with Daniel Gregg and Alexandra Peralta) focuses on household decision-making about resources and which factors may affect efficiency of household behaviour. In particular, employing the BeckerDeGroot-Marschak (BDM) mechanism, we elicit the willingness of women and men to pay (WTP) to receive a small cash transfer in private (secret from their spouse) instead of publicly (known by their spouse). Our results show that partic- 
ipants are willing to give up on average half of the money they can earn from the experiment to receive it in private.

Additionally, we document a negative and significant relationship between willingness to hide income and women's empowerment (say in household decisions), frequency of conflict and aggression in the household, and membership in savings groups. Exploiting the random assignment of endowment either privately or publicly, conditional on stated WTP, we find evidence that individuals take advantage of the information asymmetries within the household to alter allocations of household resources towards private consumption (men) and to avoid claims over it by their partner (women). Our findings thus contribute to understanding of rural household behaviour which has large implications on the effectiveness of interventions in the path of poverty reduction and development.

\subsection{Study background}

Sub-Saharan Africa possesses 12 percent of the world's arable land, yet the share of sub-Saharan Africa in the world's agricultural exports is approximately 2 percent (FAO, 2008) indicating that poorest smallholders fail to participate in and benefit from export markets to a large extent. Uganda is one such country with one of the highest concentrations of extreme poverty in the world (World Bank, 2020) with more than 70 percent of the population living in rural areas (UBOS, 2018).

Coffee is one of the traditional cash crops and a major source of income for 1.7 million smallholder coffee growers in Uganda (UCDA, 2020). Coffee is also the most important agricultural export, with a contribution of approximately 20 percent to the total exports of the country (ICO, 2019). Two species of coffee are of importance: Coffea Canephora (also referred to as robustas) and Coffea Arabica (also referred to as milds). Arabica coffee is more aromatic and flavourful than Robusta coffee and is a higher-end product, which is why Arabica prices on average are twice as much as Robusta prices in the world market (ICO, 2020). Less than 20 percent of the coffee grown in Uganda is Arabica coffee, yet Ugandan Robusta exports are worth 355 million USD whereas Arabica exports are worth 138 million USD (UCDA, 2020).

Given the growing international demand for high-quality coffee and excess supply of low-quality coffee products, high-value Arabica coffee production is an opportunity to be seized to transform agriculture towards high-value export products. It 
represents an excellent opportunity for smallholder coffee growers to earn higher revenues through participating in high-value coffee markets. Despite being the second largest Arabica coffee exporter in Africa after Ethiopia, Uganda lags drastically behind its African peers, such as Ethiopia, Kenya, and Rwanda, in terms of accessing high-value markets with little Ugandan coffee being traded in high-value markets (ICO, 2020).

Figure 1.1: The Mount Elgon region in eastern Uganda

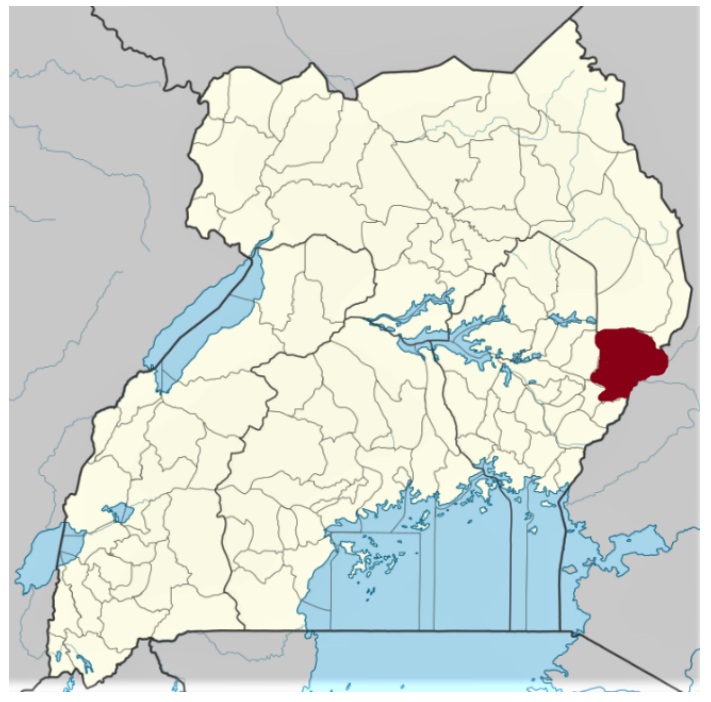

This dissertation is focused on the coffee growing households on the slopes of Mount Elgon which is an extinct volcano located on the Kenyan border of Uganda (Figure 1.1). The Mount Elgon region is particularly well-suited for Arabica coffee production due to its fertile volcanic soils, elevation, and climate. The region is the largest producer of Arabica coffee in the country and home to half a million coffee-growing families in the region of whom a large majority are smallholders (UCDA, 2020). The region has high potential to benefit from high-quality coffee markets, yet it appears not to be the case. Relatively low levels of high-value market participation can partly be explained by the inability to create the value-added and meet the standards required by the high-value markets. Limited value transmission to large numbers of smallholder coffee farmers means that many of these farming households remain unable to access improved livelihoods. The Mount Elgon region is thus an excellent context to study constraints on high-value market participation allowing for investigating research questions related to adoption of quality improvements, high-value market participation, value chain upgrading, and constraints to improved income in the coffee value chain. Similar to many other areas, women provide a substantial share of the coffee labour in the area, yet have little control over coffee sales nor do they inherit or own any coffee farm. 
The region thus presents itself as a suitable context to study welfare, decision making, and resource allocations of rural households in poor countries.

\subsection{Data}

This dissertation relies on primary data collected from coffee-growing households in the district of Kapchorwa, the largest Arabica coffee producing district in Uganda. A list of coffee growers was obtained from the largest coffee exporter in eastern Uganda that has operated in the project region for approximately 20 years and dominates coffee markets in the region (UCDA, 2020). The randomly drawn sample consists of 1600 coffee-producing households across 190 villages in 19 parishes of the district.The first essay explores the role of different communicators in information delivery regarding coffee quality and high-value market participation building on a clustered randomised experiment for causal inference. Baseline data collection took place in the months of March and April 2018. The intervention was implemented in August 2018. Follow-up data were collected in late February through early April 2019. We have collected data on coffee production and sales, socio-demographic characteristics, knowledge about coffee quality, cognitive ability, and market access among others. The second essay takes advantage of the rich baseline data to analyse the profitability of upgrading through processing and explore the role of several other drivers or processing decisions. Since the data is of cross-sectional nature we take an instrumental variable approach for causal inference. The third essay is concerned with household decision-making and relies on separate experiment conducted in November 2019. The sample of this essay consists of 422 households randomly drawn from the 1600 farmers interviewed within the framework of the randomised experiment. Further details regarding the data and empirical strategy of each essay are provided in respective chapters.

\subsection{Roadmap}

The rest of this dissertation is organised as follows. The next chapter presents the first essay analysing the role of the communicator in agricultural information delivery exploiting a randomised controlled trial. Chapter 3 consists of the second essay focusing on value upgrading through processing, in particular, its effect on farm profitability and potential drivers. Chapter 4 analyses the efficiency of decision-making and the role of asymmetric information on spending behaviour of the households in the region. Chapter 5 concludes. 


\title{
Chapter 2
}

\section{Who communicates the information influences what technology is adopted: evidence from Uganda}

\begin{abstract}
A lot is known about the role of information in agricultural technology adoption in developing countries but less is known about the importance of who the communicator of the information is. We conduct a field experiment to assess the effects of information delivered through two different extension approaches on adoption of quality-enhancing practices and high-value market participation by smallholder coffee farmers in Uganda. In the first approach a peer farmer supports an extension worker whereas in the second approach a high-status market actor supports an extension worker in communicating information to farmers. Based on the persuasiveness attribute of the communicator we hypothesise that farmers in the peer farmer treatment group adopt quality-improving practices, whereas farmers in the market actor treatment group participate in high-value markets to a larger extent than the standard extension-worker-only treatment farmers. We find results consistent with our hypothesis. We also find evidence that quality improvements and high-value market participation lead to higher coffee revenues. We contribute to the literature of extension in technology adoption and of high-value market participation by smallholder farmers in developing countries.
\end{abstract}

Keywords: technology adoption; information failure; extension; agriculture; highvalue markets; coffee; Africa

JEL Codes: O1, O3, Q1, D8

This paper is a joint work with Meike Wollni, Judith Oduol, and Karl Hughes. I developed the research idea, collected and analysed the data, and wrote the manuscript. Meike Wollni contributed to developing the research design, provided significant feedback at various stages of the research, and revised the manuscript. Judith Oduol and Karl Hughes contributed to developing the research design and provided feedback at various stages of the research. This project has been approved by the University of Goettingen Ethics Board and Makerere University School of Social Sciences Research Ethics Board (MAKSS REC 03.18.138). This experiment was registered with the AEA RCT web registry with RCT-ID AEARCTR-0004175. 


\subsection{Introduction}

Agricultural technology adoption is associated with higher agricultural income and reduced poverty in developing countries (World Bank, 2007). ${ }^{1}$ In many areas, however, technologies with a large potential to increase agricultural income are not largely adopted (Gollin et al., 2005; Udry, 2011). A large body of literature identifies the factors that affect adoption of agricultural technologies particularly in developing countries, such as socio-demographic and farm characteristics, and behavioural factors (Feder et al., 1985; Foster and Rosenzweig, 1995; Doss and Morris, 2000; Knight et al., 2003; Knowler and Bradshaw, 2007; Foster and Rosenzweig, 2010; Duflo et al., 2011). Heterogeneity in individual and farm characteristics generates differences in expected returns and thus affects adoption decisions (Suri, 2011).

In addition, individual adoption decisions reflect the distortions created by market inefficiencies. ${ }^{2}$ Information inefficiencies are increasingly identified as a hindrance to technology adoption in agriculture in developing countries (Jalan and Somanathan, 2008; Conley and Udry, 2010; Aker and Ksoll, 2016; Ogutu et al., 2020). In his review of recent studies on technology adoption in developing countries Magruder (2018) points out that information constraints may be different for unfamiliar technologies than for familiar ones. A lack of information about unfamiliar practices and their suitability to local conditions precludes adoption by farmers (Godtland et al., 2004; Van den Berg and Jiggins, 2007; Hoerner et al., 2019). In some cases, on the other hand, the practice is familiar, but farmers are not fully informed about its optimal use (Hanna et al., 2014; Islam, 2014; Cole and Fernando, 2016). This paper focuses on the role of information in adoption of practices that farmers are familiar with but do not optimally employ, such as improved harvest practices to increase the quality of the coffee produced (qualityimproving practices). ${ }^{3}$ Specifically, the first research question we seek to answer is the following: is information a barrier to adoption of quality-improving practices?

\footnotetext{
${ }^{1}$ Following Foster and Rosenzweig (2010), by technology we mean the relationship between inputs and outputs, and adoption of new technologies refers to the use of new mappings between inputs and outputs and changes in the allocations of inputs that exploit the new mappings. We use the framework of technology adoption because practices to increase product quality and participation in high-value markets are use of new mappings between inputs and outputs.

${ }^{2}$ Jack (2013) provides a comprehensive review of barriers to technology adoption. Such inefficiencies may occur in credit markets, insurance markets, land markets, input markets, output markets, and labour markets and include externalities (Wozniak, 1993; Besley and Case, 1994; Fafchamps et al., 2008; Goldstein and Udry, 2008; Ashraf et al., 2009; Cohen and Dupas, 2010; Udry, 2011; Cole et al., 2013; Beltramo et al., 2015; Karlan et al., 2015).

${ }^{3}$ This falls under "quality-enhancing innovations" in the classification made by Sunding and Zilberman (2001) within the framework of adoption of innovations.
} 
A lack of market-related information and uncertainty about markets (e.g. prices, commercialization) is likely another factor which hinders optimal production and marketing decisions (Jensen, 2007; Ashraf et al., 2009; Goyal et al., 2010; Aker, 2011). In the coffee sector, in particular, Wollni and Zeller (2007) indicate that a lack of access to information about requirements of specialty (high-quality) coffee markets impedes smallholder participation in these markets which are associated with higher revenues. Informed by these insights, we ask the second research question: is information a barrier to high-value market participation? We essentially test whether providing farmers with information about improved harvest practices for higher coffee quality and high-value market participation leads to adoption of quality-improving practices and higher levels of high-value markets participation by smallholder farmers.

Agriculture-related information can be communicated to farmers in developing countries through traditional extension services, modern communication technologies, or social networks. Agricultural extension services are a common form of government support of technical knowledge diffusion to individual farms accounting for a considerable share of government expenditures on agriculture in developing countries (Akroyd and Smith, 2007; Birkhaeuser et al., 1991). The evidence on the effectiveness of these extension services is, however, inconclusive (Feder et al., 1987; Birkhaeuser et al., 1991; Gautam, 2000; Krishnan and Patnam, 2014). Given the potentially large role of extension services in information delivery to farmers in developing countries, efforts should be made for developing complementary extension approaches or modalities effective in communicating information and persuading farmers to adopt promoted practices. ${ }^{4}$

Kondylis et al. (2017) test the effectiveness of augmenting the traditional extension programme with directly training "contact farmers" (farmers who are functioning as a bridge between government extension agents and farmers). This approach proves effective in persuading trained contact farmers to adopt but fails to induce adoption by the rest of the farmers in the community. BenYishay and Mobarak (2019) test the effectiveness of a "peer farmer" approach wherein a peer farmer (who is representative of the average farmer) is trained on the technology promoted and expected to operate alongside the extension worker. They find that the peer farmers are ineffective when they are only trained but become effective

\footnotetext{
${ }^{4}$ Most extension systems rely on agricultural extension workers whose job is to provide information and technical advice to individual or groups of farmers. With extension we basically mean the training and visit $(\mathrm{T} \& \mathrm{~V})$ type of extension systems.
} 
and positively affect the adoption rates of farmers in the community when they are given small incentives. BenYishay and Mobarak (2019) argue that peer farmers are persuasive communicators because they are representative of the average farmer i.e. their experiences and conditions are similar (comparable) to that of most farmers in the community. Their approach thus draws attention to the "persuasive effectiveness" dimension of information delivery in addressing information inefficiencies in agriculture.

In the social psychology literature the central aspect of persuasive effectiveness of a communicator is argued to be credibility (Hovland and Weiss, 1951; McGuire, 1969) which has two dimensions: competence and trustworthiness (Hovland et al., 1953; Eagly and Chaiken, 1984; Renn and Levine, 1991; McCroskey and Teven, 1999). Building on these findings and that of BenYishay and Mobarak (2019), we propose that a comparable peer farmer who, in our case, employs qualityimproving practices (competence attribute), and known and trusted by the farmers in the community (trustworthiness attribute) may be an effective source of information about quality-improving practices. The third research question we seek to answer is thus the following: is information delivered through an extension modality wherein a peer farmer supports the extension worker in communicating information in an extension meeting more effective in inducing adoption of quality-improving practices by farmers than the standard extension-worker-only approach?

A key aspect of this study is that farmers are provided with information not only about improved harvest practices for higher coffee quality but also about highvalue markets. Yet, by the same token, it is not clear to what extent an extension worker can be considered an effective source of market-related information due mainly to a lack of competence or expertise about markets. We propose that, instead, a high-level manager of a large coffee exporter is more informed and expert (competent) regarding high-value coffee markets and is able to elicit trustworthiness in others because of his high status (Glaeser et al., 2000) and thus a more persuasive source of information about high-value markets than an extension worker. The fourth research question is thus as follows: is information delivered through an extension modality wherein a high-status market actor supports the extension worker in communicating information in an extension meeting more effective in increasing high-value market participation by farmers than the standard extension-worker-only approach? In addition to documenting the effects of different extension approaches on adoption of the two promoted practices, we attempt 
to answer the following questions: (i) Do farmers earn higher coffee revenues as a result of the information provided regarding quality-improving practices and high-value markets? (ii) Do revenues differ across treatments? (iii) What are the relative contributions of coffee quality and high-value market participation to coffee revenues?

To answer our research questions we randomly assigned a total of 88 coffee farmer groups and respective members into treatment and control groups. The treatment was essentially an invitation to an extension meeting which was organised to provide coffee farmers with information about improved harvest practices for higher coffee quality and participation in high-value markets whereas control group farmers did not receive any invitation. In each and every meeting, the information was communicated by an extension worker and in a random subset of these meetings farmers received the same information also from a peer farmer or from a high-status market actor. Hence, the experimental design includes three treatment arms, communication by an extension worker (T1), by an extension worker and a peer farmer (T2) and by an extension worker and the market actor (T3), and a control group. The content was kept identical in that the exact same information was communicated in all meetings. This allows us to make a general treatmentcontrol comparison to assess the effect of information provision on adoption decisions. Incorporating a peer farmer and a high-status market actor as a communicator in extension meetings allows for testing the effectiveness of these two approaches compared to the standard approach i.e. information communicated only by an extension worker.

Key outcome variables are adoption of quality-improving practices (measured by harvest quality scores), high-value market participation in shares, and revenues earned per kilogramme of coffee harvested in Ugandan Shillings (UShs). Intentionto-treat (ITT) estimation results suggest that information is a barrier to adoption in that treated growers have higher levels of harvest quality and high-value market participation than control group growers. Coffee growers who are in the peer farmer treatment group (T2) adopt quality-improving practices to a larger extent than the standard extension group farmers (by 30 percent) but the effect on highvalue market participation between the two groups is not significantly different. Coffee growers in the market actor treatment group (T3) do not adopt qualityimproving practices significantly more than the extension-worker only treatment group. However, they do have significantly higher levels of high-value market participation and coffee revenues per kilogramme than the standard extension 
group growers. Comparing the peer farmer (T2) and the market actor (T3) approaches, we find that farmers in T2 have significantly higher levels of harvest quality whereas farmers in T3 have significantly higher levels of high-value market participation, but the difference in revenues earned per kilogramme between the two is statistically insignificant. Hence, results indicate who communicates the information influences what technology is adopted.

This study draws on several strands of the literature. It relates mainly to the literature that studies the role of information in agricultural technology adoption in developing countries. A large number of the studies in this literature focus on information diffusion through social networks and social learning (Munshi, 2004; Bandiera and Rasul, 2006; Conley and Udry, 2010; Maertens and Barrett, 2013; Beaman et al., 2018) whereas we study the effect of information delivered through extension services and, in particular, explore the role of an additional communicator who supports the extension worker. Considering the limited causal evidence on the effectiveness of complementary extension approaches and modalities (Kondylis et al., 2017; BenYishay and Mobarak, 2019), our study contributes to this nascent literature by testing the effectiveness of two different extension modalities on adoption of quality-enhancing practices and high-value market participation in the coffee value chain. More specifically, we add to the scarce experimental evidence on the effectiveness of peer farmer modalities. Additionally, we contribute to the scarce literature that explores the role of non-traditional communicators in diffusion of agricultural information by testing the effectiveness of a novel approach in which a high-status market actor supports the extension worker in information provision. One related study by Emerick and Sadoulet (2017) shows that selecting agro-dealers as entry points in the diffusion of information regarding an agricultural technology is more effective than the contact farmer approach due partly to their expertise in the technology.

Additionally, studies that analyse the effect of information on technology adoption in the literature do not always assess treatment effects on farmers' revenues due possibly to a difficulty in capturing returns within short time frames (Kondylis et al., 2017; Hoerner et al., 2019; Ogutu et al., 2020). We thus extend our contribution by analysing the effects of information provided through extension on not only adoption but also on agricultural income. Moreover, nearly all the studies in the literature focus on productivity- or yield-increasing practices, whereas we differentiate our study by focusing on practices that enhance product quality (value addition) and on high-value market participation. Hence, this study also relates 
to the value chain development literature that documents income effects of participation in high-value markets on smallholder farmers in developing countries (Maertens and Swinnen, 2009; Minten et al., 2009; Rao and Qaim, 2011; Barrett et al., 2012; Ogutu and Qaim, 2019). Specifically, we study high-value market participation through product upgrading by value-addition. Studies in this literature focus predominantly on effects of product upgrading by certification (Ruben and Fort, 2012; Chiputwa et al., 2015; Meemken and Qaim, 2018; Dragusanu and Nunn, 2018). One early exception is that of Wollni and Zeller (2007) who study upgrading through quality improvements and participation in high-value coffee markets using observational data. A recent exception is that of Macchiavello and Miquel-Florensa (2019) who document the effects of a comprehensive coffee quality-upgrading intervention on coffee farmers in Colombia. We thus add to the nascent experimental literature on returns to value-addition through enhanced product quality and participation in high-value markets.

This paper is organised as follows. The next section gives background information related to the coffee sector. Section 3 provides a simple conceptual framework for our experiment. Section 4 presents the experimental design and the treatments. Section 5 describes our data and estimation strategy. Section 6 presents the results. Last section concludes.

\subsection{Study context}

Coffee production has large potential to provide substantial increases in agricultural income in developing countries particularly when farmers participate in highvalue coffee markets (Wollni and Zeller, 2007; Macchiavello and Miquel-Florensa, 2019). Failure to participate in high-value markets thus implies a potentially large income loss for the smallholder coffee producers in developing countries. Coffee is a major cash crop in Uganda, the second largest Arabica coffee exporter in Africa after Ethiopia. However, there is relatively a small volume of Ugandan Arabica coffee traded in high-value markets (ICO, 2020). Relatively low levels of highvalue market participation can partly be explained by the inability to meet the high quality standards required by the market in addition to limited access to such markets. Our study site, the district of Kapchorwa in Uganda, is located on the slopes of Mount Elgon which is an extinct volcano located on the Kenyan border of Uganda. Despite that the Mount Elgon area is well suited for Arabica coffee production due to its fertile volcanic soils, elevation, and climate, coffee from the region fails to reach its potential in terms of quality and participation in high-value 
markets.

A key factor determining coffee cherry quality is harvesting practices. Harvesting only fully ripe coffee cherries is a precondition for and immature harvest is a threat to achieving high coffee quality (Wasserman et al., 2000). Cherries which are unripe, overripe, dried up, and damaged from bacteria or fungi are of low quality and should not be harvested (Goto and Fukunaga, 1986; Kuit et al., 2004). Hence, selectively hand-picking cherries results in much higher quality coffee by decreasing the percentage of low-quality cherries in coffee batches compared to the alternative of stripping (Leroy et al., 2006; Ameyu, 2017). Selectively hand-picking cherries requires more frequent picking to prevent cherries from overripening as well. Improved harvest practices require coffee growers to make minor changes in harvest methods mainly by seeking to manage coffee picking periods to maximise fully ripe coffee cherries harvested. Poor processing of coffee cherries also results in unpleasant flavors and aromas which considerably lower coffee cup quality.

As a result of the liberalization of the coffee sector in Uganda in 1996, thousands of coffee buyers gradually entered the coffee market (Baffes, 2006). Currently, traders, processors, and exporters can directly purchase coffee from primary producers. Producers are free to market their coffee in any channel. However, marketing channel choice is key to maintain coffee quality and participate in high-value markets. Most buyers, such as traders, operate in commodity (conventional) coffee markets which do not have strict quality requirements. Traders usually buy coffee from several different coffee growers. Traders also buy coffee of any quality and mix them to make the coffee "just good enough" to be traded in the commodity coffee market in Mbale which is a big city outside Kapchorwa. This practice is associated with large value losses given that the coffee has a great potential in high-value markets. It also lowers quality of coffee due to postharvest decays since coffee cherries are highly perishable and should instead be processed quickly after harvest. In the study area, there is one large coffee exporter that operates in high-value markets, has modern processing facilities and resources to monitor coffee quality during processing. The exporter has buying centers in many parishes across the district facilitating market access for farmers. However, selling coffee to this exporter is subject to passing a minimum quality threshold since it targets high-value markets.

Informed by these insights, we organised an extension meeting in which we provided farmers with information regarding improved harvest practices for higher coffee quality and high-value market participation. The aim of the extension meet- 
ing was to encourage quality improvements and subsequent high-value market participation so that smallholder coffee growers earn higher coffee revenues.

\subsection{Conceptual framework}

We present a simple conceptual framework which relies on a framework adapted from the standard target input model widely used in the literature (Foster and Rosenzweig, 1995; Munshi, 2004; Bandiera and Rasul, 2006), presented in Bardhan and Udry (1999) and further developed by BenYishay and Mobarak (2019). The underlying framework is that farmers maximise their expected pay-off i.e. agricultural income. We start with the observation that there is a technology of which the required inputs for optimal implementation (e.g. effort into improved harvest practices) and returns to optimal implementation of the technology (e.g. prices) are not fully known ex-ante to farmers. Suppose that farmer i chooses her input level according to her prior beliefs about the technology and there is a gap between the farmer's beliefs and the actual level of input required for optimality. Similar to what is presented by Hanna et al. (2014), farmers fail to optimise along input dimensions they do not notice. As a result, farmer i's expected payoff from the new technology is lower than the maximum pay-off that she can have.

Suppose further that there is a communicator that sends a positive signal to farmer $i$ about the new technology. We assume Bayesian updating i.e. the farmer updates her beliefs about the new technology as new information is acquired. Farmer i then faces a choice between the traditional technology and the new technology promoted. Our first hypothesis is that the positive signal received about the new technology induces adoption of this technology by the target farmer. In Hanna et al. (2014) information helps the farmer see the optimal input relationships and lead her to alter input choices towards optimality. In his study of human capital and disequilibria, Schultz (1975) argues that the introduction of new techniques lead to a period of disequilibrium where resources are not utilised efficiently by the individual farmer and describes learning as moving toward new equilibrium levels. The problem of learning in our case is concerned with discovering the extent to which the pay-off from adopting the new technology is higher than that of the traditional one under farmer's particular circumstance as in Besley and Case (1994).

In the standard target input model, a farmer's expected pay-off from the new technology increases in her proximity to an informed communicator. In BenYishay and Mobarak (2019) communication effectiveness is increasing in the proximity 
between the farmer and the informed communicator. This proximity is interpreted as similarity of the recipient farmer to the sender of the signal or comparability of their agronomic conditions. Similarity (comparability) of the communicator to the farmer indicates how relevant the information communicated is for the farmer and thus increases adoption of the new technology through the channel of persuasiveness (BenYishay and Mobarak, 2019). In our model, adoption by the individual farmer increases in persuasive effectiveness of the communicator of the information.

Hovland and Weiss (1951) and McGuire (1969) argue that the central aspect of persuasive effectiveness of a communicator is credibility. Studies in the social psychology literature have agreed on two dimensions of source credibility: "competence" (expertness, qualification, and well-informedness) and "trustworthiness" (Hovland et al., 1953; Eagly and Chaiken, 1984; Renn and Levine, 1991; McCroskey and Teven, 1999). Applying this to our context, we argue that a farmer who already employs quality-improving practices is knowledgeable about the practice (competence attribute). ${ }^{5} \mathrm{~A}$ farmer who is representative of the average farmer from the same area is known and trusted by most farmers in the community (trustworthiness attribute). Hence, a peer farmer with these attributes is perceived credible by the farmers in the community. Our second hypothesis is that farmers in the peer farmer treatment group who receive the information from such a peer farmer (T2) adopt the quality-improving practices to a larger extent than those in the extension-worker-only group (T1).

In our study, farmers are provided with information about not only coffee quality improvements but also high-value markets. However, it is not clear to what extent an extension worker is considered a credible source of market-related information by target farmers. On the other hand, a high-level manager of a large coffee exporting company is well-informed and expert (competent) regarding high-value coffee markets and potentially perceived more competent by the target farmers. In addition, high-status individuals are able to elicit more trustworthiness in others (Glaeser et al., 2000). ${ }^{6}$ Applying this to our context, we argue that a high-status market actor who is competent about high-value markets and trustworthy because

\footnotetext{
${ }^{5}$ Notice that we do not train a selected peer farmer. Instead, we invite a pre-identified peer farmer to the extension meeting to communicate the information along with the extension worker. Peer farmers were identified by the responsible extension worker in the area. We asked extension workers to identify a peer farmer who is representative of the average farmer (not too educated or wealthy and in good terms with the farmers in the community) and who employs quality-improving practices and high-value market participation to a certain extent.

${ }^{6}$ In their conceptualization of persuasion, the well-know Yale group identify status as another persuasiveness factor regarding the source of communication (Hovland and Janis, 1959).
} 
of his status is a more effective communicator of market-related information than an extension worker. Our third hypothesis thus is that farmers who are in the market actor treatment arm (T3) participate in high-value markets to a larger extent than those in the extension-worker-only treatment group (T1).

\subsection{Experimental design}

We test our hypotheses making use of a randomised field experiment implemented in eastern Uganda. Prior to randomisation, the sample was stratified over broad categories of three variables which might affect information take-up and adoption of quality-improving practices, and high-value market participation. ${ }^{7}$ The variables used for stratification are education level of the household head (2 categories: primary school completed or not), geographic regions (3 altitude belts: lower, middle and upper belt), and baseline coffee harvest levels (3 categories: low, medium, and high).

We randomly assigned a total of 88 farmer groups into three treatment groups and a control group. ${ }^{8}$ The first treatment group consists of 344 households in 20 farmer groups, the second and third treatment groups consist of 333 households in 19 farmer groups each and the control group consists of 512 households in 30 farmer groups. We had a preference for a slightly larger control group to have higher statistical power to analyse the overall effect of information provision treatment against the control group. We randomised treatment at the farmer group level in order to minimise spill-overs and behavioural changes across treatment groups (Duflo et al., 2007). Additionally, household surveys and the intervention were implemented by different field teams affiliated with different organisations. Lastly, the questions hinting at the intervention were asked after all the coffeerelated questions at the end of the survey to reduce experimenter demand bias in our outcome measures to the extent possible.

Information spill-overs from treatment to control group farmers constitute a threat to the internal validity of our experiment. To measure spill-overs to a certain extent, we used a slogan introduced during the meeting assuming that if coffee

\footnotetext{
${ }^{7}$ We used the Stata command randtreat developed for stratified randomisation dealing with misfits by Carril (2017) following the idea of Bruhn and McKenzie (2009) and adapted it according to our cluster-level randomisation. We used three variables for stratification which generated 17 strata and we balance 88 groups.

${ }^{8}$ Farmer groups in our setting do not act as cooperatives. They do not have buying or marketing roles. Formation of farmer groups are encouraged mainly for extension purposes by the largest exporter in the area. Farmer groups are formed usually at the village level. When villages are small, however, farmers from nearby villages make up one farmer group.
} 
growers talk to each other about the meeting they would mention the slogan. Only about 10 percent of the growers in the sample report to have heard of the slogan and have not attended the training. Note that some growers report to have heard of the slogan when two other people were talking, for instance, in public transport. It is highly unlikely that just hearing the slogan causes meaningful changes in farmers' behaviour. Hence, spill-overs appear to be limited in our case. Note that spill-overs would only lead to a downward bias in our estimates. This implies that the effects measured can be considered the lower bound of the true effects.

We employed an encouragement design for our randomised experiment i.e. only households in the randomly-selected-treatment groups were invited to the extension meetings and not control group households. However, several farmers from the control group showed up for a meeting held in a nearby village and received the treatment. Eventually 68 percent of the treatment households and 24 percent of the control households reported to have attended the extension meeting we organised. This reduces the statistical power of our experiment and results in underestimation of average treatment effects. Table 2.1 presents compliance with the random assignment across treatment groups. Compliance rates across the three treatment groups are not significantly different from each other.

Table 2.1: Compliance with random assignment

\begin{tabular}{lccc}
\hline \hline & Treatment & Control \\
\hline Assigned to Treatment & 1,010 & 0 \\
Received Treatment & & 682 & 122 \\
Compliance rate & & $\mathbf{6 7 . 5}$ & 76.2 \\
Non-compliance rate & $\mathrm{3} 1.5$ & $\mathbf{2 3 . 8}$ \\
\hline & 344 & $\mathrm{~T} 2$ & $\mathrm{~T} 3$ \\
\hline Assigned to Treatment & 232 & 228 & 333 \\
Received Treatment & 67.4 & 68.5 & 221 \\
Compliance rate & & Difference & p-value \\
\hline & & -0.01 & 0.862 \\
\hline T2-T1 & & 0.01 & 0.839 \\
T3-T1 & & \\
\hline \hline
\end{tabular}

Notes: ${ }^{\mathrm{a}} \mathrm{p}$-values for a test of mean difference based on a linear regression with standard errors clustered at the farmer group level.

\subsubsection{Treatments}

The intervention was implemented in collaboration with the largest coffee exporter in the study area. Extension meetings were led by the extension workers of the company who train coffee farmers on good agricultural practices and sustain- 
ability roughly twice a year. ${ }^{9} 12$ field extension workers received two-day training on coffee quality and improved harvest practices and international markets from a team of coffee experts and project partners. The extension meetings lasted 3-4 hours and each farmer group met once. All the extension meetings were held in the month of August 2018, about a month before the harvest season started. The meetings were typically held in school or church structures in the village. Treatment farmers were informed about the meeting 2-3 days before the meeting took place. All the members of the treatment farmer groups, and not only the households we interviewed, were invited to the meetings in their village.

The intervention was essentially an extension meeting (training) in which information about improved harvest practices for higher coffee quality and high-value market participation were communicated to coffee farmers. In particular, the meeting focused on two topics: (i) Improved harvest practices (sufficiently delaying harvest, and selective and frequent picking) for highest coffee quality; and (ii) Participation in high-value coffee markets and its relation to coffee quality. We also came up with a quick and catchy slogan for the training: Pick for profit: pick selectively pick frequently. We instructed extension workers to repeat the slogan 3 times during each meeting. We specifically made up a slogan in order to make it easier for farmers to remember it and thus the main message of the training. The slogan also helps us identify who attended the meeting in the survey data (in case farmers confuse the meeting we organised with another meeting).

To keep the content (information) identical across treatment groups we standardised the material (script, guidelines, and pictures for demonstration) used during the meeting. We instructed extension workers to strictly adhere to the content of the information provided and follow the order. Keeping content standard, we varied the communicator in each treatment arm. Farmers in the first treatment group (T1) were invited to an extension meeting in which they received the information from only an extension worker. These extension meetings took place about a month before the harvest season started and extension workers did not have any other extension meeting with the farmers before the harvest season, either.

Farmers in the second treatment group (T2) were invited to a meeting in which the same information was delivered by an extension worker and a peer farmer briefly talked about improved harvest practices and high-value market participa-

\footnotetext{
${ }^{9}$ Extension workers who led the meetings we organised work for the exporter and not for the government but they operate in a similar way to government extension workers in terms of duration and intensity of training, among others.
} 
tion. The peer farmer was identified and invited to the meeting by the responsible extension worker from the area. The criteria used to select the peer farmer were that the peer farmer should be an average farmer (average farm size, wealth, and education) from the farmer group and in good terms with the community, and who already employs improved harvest practices and high-value market participation to a certain extent. The idea was simply to have a plausibly more credible (persuasive) communicator about coffee quality on board to test the effectiveness of this approach. Note that in some of the peer farmer treatment groups (mainly in the first few days of the implementation), a peer farmer could not be identified by the extension workers in due time and the treatment could not fully be implemented. We control for this "failure" in our estimations using an indicator variable.

Farmers assigned to the third treatment group (T3) were invited to a meeting in which they received the same information from an extension worker and a high-status market actor briefly talked about improved harvest practices for higher coffee quality and high-value market participation. The high-status market actor is the project manager of the largest coffee exporter in the area and in charge of all operations. The idea was simply to incorporate a more credible and thus persuasive source of market-related information and test the effectiveness of this approach. The market actor addressed the farmers as a group and did not talk to farmers individually during the meetings. He did not establish contact with any of the farmers and did not interact with farmers any time after the meeting. He was introduced to farmers by his name and title (project manager of the company) by the extension worker leading the training. He attended the meeting for 15-20 minutes solely to communicate the standardised information.

\subsection{Data and estimation strategy}

\subsubsection{Data}

Primary data was collected by interviewing randomly selected coffee growers in a total of 88 farmer groups in the district of Kapchorwa (Figure 2.1). 10-25 growers from each of the 88 farmer groups were interviewed. We varied the number of interviews per farmer group roughly with respect to the size of the farmer group. A list of farmer groups and respective farmers was obtained from the largest coffee exporter which has operated in the project region for approximately 20 years and dominates coffee markets in the region (UCDA, 2020).

Baseline data collection took place in the months of March and April 2018. Follow- 
Figure 2.1: Treatment status of the households in our sample

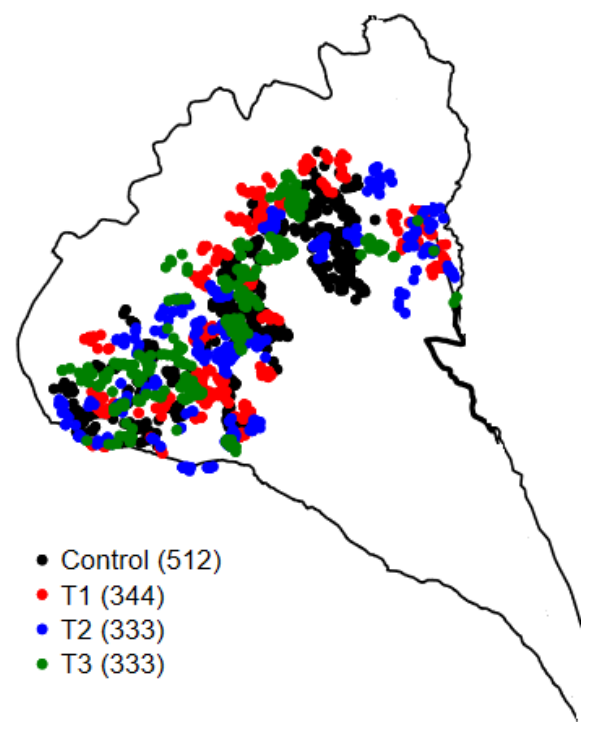

up data were collected in February and March 2019. Table 2.2 presents the number of households in the baseline and follow-up sample and attrition rates. Attrition rate between the baseline and follow-up survey is 5.8 percent. There is less attrition in the third treatment arm, but the difference is only marginally significant. Since estimations show no large difference between attritors and non-attritors in their baseline characteristics and overall attrition rate is not very high, lower rate of attrition in T3 than T1 appears not to be a big concern. For the analysis we use a balanced panel of 1522 observations with complete data in both survey rounds.

Table 2.2: Attrition between baseline and follow-up surveys

\begin{tabular}{lccc}
\hline \hline & Baseline sample & Follow-up sample & Attrition rate (\%) \\
\hline T1 & 377 & 344 & 9.59 \\
T2 & 355 & 333 & 6.66 \\
T3 & 334 & 333 & 0.30 \\
Treatment & 1066 & 1010 & 5.55 \\
Control & 544 & 512 & 6.25 \\
Total & 1610 & 1522 & 5.78 \\
\hline & & Difference & p-value \\
\hline Treatment-Control & 1.42 & 0.38 \\
T2-T1 & -0.94 & 0.64 \\
T3-T1 & 0.11 & 0.09 \\
\hline \hline
\end{tabular}

Notes: ${ }^{a}$ p-values for a test of mean difference based on a linear regression with standard errors clustered at the farmer group level.

Key outcome variables are adoption of coffee quality-improving harvest practices, high-value market participation, and revenues earned per kilogramme of coffee 
harvested. Adoption of quality-improving practices is captured with a harvest quality score variable (0-3) constructed using two different aspects of improved harvest practices, namely, sufficiently delaying harvest for higher quality coffee and harvesting selectively and frequently in addition to self-reported quality at harvest. Firstly, we use the information whether the household delayed harvest to improve the quality of cherries in the last harvest season. Secondly, we calculate seasonal labour days for coffee picking per ton of harvested coffee to basically capture efforts to improve picking quality. Growers need coffee pickers to harvest their coffee and more labour days (per ton of coffee harvested) can be considered an effort to improve harvest practices since selective and frequently harvesting requires more effort. Thirdly, to measure subjective coffee quality at harvest, we use growers' estimations of the percentage of low-quality (unripe, overripe, and damaged) cherries in a typical harvest basket at the time of harvest prior to any sorting. The answers are recorded in 5-percentage-point brackets (e.g. 0-4.99 percent, 5-9.99 percent and 10-14.99 percent etc). We transform the information recorded in brackets to measure the share of high-quality cherries at harvest e.g. the transformed bracket of 0-4.99 percent of low-quality cherries corresponds to 95.01-100 percent of high-quality cherries in a given basket. All the 3 variables are scaled down to vary between 0 and 1 and added to each other to construct the harvest quality index (0-3). We do not apply weights and simply count the 3 variables (scaled down to vary between 0 and 1 ) to construct the harvest quality scores. The details are presented in Appendix A. We acknowledge that the variable we constructed to measure harvest quality may be an imperfect measure of coffee quality at harvest, given that harvest quality is fairly difficult to quantify and measure at the household level.

Another outcome of interest is high-value market participation which is measured by the share of coffee sold to the exporter in all the coffee harvested. ${ }^{10}$ Since selling coffee to the exporter is subject to passing a quality threshold it signals a certain level of coffee quality, which increases the chances of coffee being traded at the high-value coffee markets. For this reason, selling coffee to the exporter is interpreted as an attempt to participate in high-quality coffee markets. Lastly, revenues earned per kilogramme is calculated by dividing total coffee revenues by the quantity of coffee harvested in the last harvest season (average prices). In

\footnotetext{
${ }^{10}$ There is no home consumption of coffee and the difference between the quantity produced and sold is negligible.
} 
particular, household-level revenues per kilogramme $r_{i}$ are calculated as follows:

$r_{i}=\frac{\sum_{d=1}^{D} q_{i, d} p_{i, d}}{H_{i}}$

where

$q_{i, d}=$ Quantity of coffee sold on day $d$ by household $i$

$p_{i, d}=$ Price received for coffee sold on day $d$ by household $i$

$H_{i}=$ Total quantity of coffee harvested by household $i$

Additionally, to analyse whether the market actor treatment affect farmers selling coffee to the exporter through other channels than persuasive effectiveness of the communicator, we collected data on perceptions towards the exporter. In particular, we asked respondents to indicate the level of agreement with statements, such as "I trust the exporter as a coffee buyer", "I believe the exporter is trustworthy", and "I feel close to the exporter". To explore whether living up to the exptectations of the exporter is a channel through which the market actor treatment is effective, we ask the respondents to indicate the level of agreement with the statements regarding the expectations of the exporter, such as "the exporter expects to buy highest quality coffee from me" and "the exporter expects me to improve the quality of my coffee". All these questions (related to perceptions and expectations) are based on 5-point Likert scale answer options.

Regarding agronomic aspects of coffee quality, we have data on altitude belts ( 3 altitude regions) and whether the coffee gardens were attacked by pests and diseases in the last 12 months. Both are shown to be correlated with coffee tree health and thus cherry quality to a large extent (Decazy et al., 2003; Leroy et al., 2006). The number of coffee extension meetings household members attended is used to proxy motivation for coffee farming, which is usually unobserved. Other control variables include experience with coffee farming in years, household size, sex and education level of the household head, distance to nearest tarmac road, and number of household assets and livestock. 
Table 2.3: Pre-intervention balance

\begin{tabular}{|c|c|c|c|c|c|c|c|c|}
\hline & $\begin{array}{c}\text { Mean Control } \\
\mathrm{N}=512 \\
\text { (St. dev.) }\end{array}$ & $\begin{array}{c}\text { Mean Treatment } \\
\mathrm{N}=1010 \\
\text { (St. dev) }\end{array}$ & $\begin{array}{c}\text { Mean T1 } \\
\mathrm{N}=344 \\
\text { (St. dev) }\end{array}$ & $\begin{array}{c}\text { Mean T2 } \\
\mathrm{N}=333 \\
\text { (St. dev.) }\end{array}$ & $\begin{array}{c}\text { Mean T3 } \\
\mathrm{N}=333 \\
\text { (St. dev.) }\end{array}$ & $\begin{array}{c}\text { Difference } \\
\text { T-C }^{\mathrm{a}} \\
\text { (St. errors) }\end{array}$ & $\begin{array}{c}\text { Difference } \\
\text { T2-T1 } \\
\text { (St. errors) }\end{array}$ & $\begin{array}{c}\text { Difference } \\
\text { T3-T1 }^{\mathrm{a}} \\
\text { (St. errors) }^{\text {(St }}\end{array}$ \\
\hline \multicolumn{9}{|l|}{ Outcome variables } \\
\hline Harvest quality score $(0-1)$ & $\begin{array}{c}0.545 \\
(0.397)\end{array}$ & $\begin{array}{c}0.511 \\
(0.397)\end{array}$ & $\begin{array}{c}0.508 \\
(0.393)\end{array}$ & $\begin{array}{c}0.529 \\
(0.392)\end{array}$ & $\begin{array}{c}0.495 \\
(0.407)\end{array}$ & $\begin{array}{l}-0.035 \\
(0.027)\end{array}$ & $\begin{array}{c}0.021 \\
(0.034)\end{array}$ & $\begin{array}{c}-0.013 \\
(0.031)\end{array}$ \\
\hline High-value market participation (\%) & $\begin{array}{c}82.009 \\
(35.327)\end{array}$ & $\begin{array}{c}75.758 \\
(40.110)\end{array}$ & $\begin{array}{c}76.993 \\
(39.915)\end{array}$ & $\begin{array}{c}76.151 \\
(39.908)\end{array}$ & $\begin{array}{c}74.048 \\
(40.579)\end{array}$ & $\begin{array}{c}-6.251^{* * *} \\
(2.899)\end{array}$ & $\begin{array}{l}-0.842 \\
(4.576)\end{array}$ & $\begin{array}{l}-2.945 \\
(4.201)\end{array}$ \\
\hline Revenues per kg (average prices) UShs & $\begin{array}{c}1181.593 \\
(175.216) \\
\end{array}$ & $\begin{array}{c}1171.221 \\
(156.626) \\
\end{array}$ & $\begin{array}{l}1181.918 \\
(159.759) \\
\end{array}$ & $\begin{array}{l}1168.502 \\
(158.297)\end{array}$ & $\begin{array}{l}1162.665 \\
(151.286)\end{array}$ & $\begin{array}{l}-10.372 \\
(12.471)\end{array}$ & $\begin{array}{c}-13.416 \\
(18.665)\end{array}$ & $\begin{array}{c}-19.253 \\
(19.720)\end{array}$ \\
\hline \multicolumn{9}{|l|}{ Covariates } \\
\hline Coffee harvest (kg) & $\begin{array}{c}881.042 \\
(1345.985)\end{array}$ & $\begin{array}{c}876.444 \\
(1241.488)\end{array}$ & $\begin{array}{c}728.942 \\
(1069.135)\end{array}$ & $\begin{array}{c}1010.027 \\
(1483.862)\end{array}$ & $\begin{array}{c}896.360 \\
(1120.877)\end{array}$ & $\begin{array}{c}-4.598 \\
(98.961)\end{array}$ & $\begin{array}{c}281.085 \\
(173.048)\end{array}$ & $\begin{array}{c}167.418 \\
(115.849)\end{array}$ \\
\hline Altitude (meters) & $\begin{array}{l}1757.096 \\
(201.509)\end{array}$ & $\begin{array}{l}1737.282 \\
(222.535)\end{array}$ & $\begin{array}{l}1751.497 \\
(218.188)\end{array}$ & $\begin{array}{l}1768.642 \\
(242.549)\end{array}$ & $\begin{array}{l}1690.208 \\
(197.234)\end{array}$ & $\begin{array}{c}-19.813 \\
(46.131)\end{array}$ & $\begin{array}{c}17.145 \\
(70.270)\end{array}$ & $\begin{array}{l}-61.289 \\
(64.177)\end{array}$ \\
\hline Pest and disease attack $(0 / 1)$ & $\begin{array}{c}0.525 \\
(0.500)\end{array}$ & $\begin{array}{c}0.577 \\
(0.494)\end{array}$ & $\begin{array}{c}0.598 \\
(0.491)\end{array}$ & $\begin{array}{c}0.569 \\
(0.496)\end{array}$ & $\begin{array}{c}0.563 \\
(0.497)\end{array}$ & $\begin{array}{c}0.052 \\
(0.041)\end{array}$ & $\begin{array}{l}-0.030 \\
(0.069)\end{array}$ & $\begin{array}{l}-0.036 \\
(0.055)\end{array}$ \\
\hline Experience with coffee farming (years) & $\begin{array}{c}27.075 \\
(13.819)\end{array}$ & $\begin{array}{c}26.709 \\
(13.585)\end{array}$ & $\begin{array}{c}26.160 \\
(12.930)\end{array}$ & $\begin{array}{c}25.603 \\
(13.373)\end{array}$ & $\begin{array}{c}28.420 \\
(14.332)\end{array}$ & $\begin{array}{l}-0.366 \\
(0.902)\end{array}$ & $\begin{array}{c}-0.557 \\
(1.061)\end{array}$ & $\begin{array}{c}2.260 \\
(1.374)\end{array}$ \\
\hline Nr extension meetings attended in a year & $\begin{array}{c}1.188 \\
(1.425)\end{array}$ & $\begin{array}{c}1.255 \\
(1.243)\end{array}$ & $\begin{array}{c}1.289 \\
(1.304)\end{array}$ & $\begin{array}{c}1.265 \\
(1.141)\end{array}$ & $\begin{array}{c}1.208 \\
(1.278)\end{array}$ & $\begin{array}{c}0.067 \\
(0.113)\end{array}$ & $\begin{array}{l}-0.024 \\
(0.131)\end{array}$ & $\begin{array}{c}-0.081 \\
(0.140)\end{array}$ \\
\hline Distance to nearest tarmac road in $\mathrm{km}$ & $\begin{array}{c}2.418 \\
(2.895)\end{array}$ & $\begin{array}{c}2.974 \\
(3.690)\end{array}$ & $\begin{array}{c}3.231 \\
(3.699)\end{array}$ & $\begin{array}{c}3.208 \\
(3.912)\end{array}$ & $\begin{array}{c}2.463 \\
(3.392)\end{array}$ & $\begin{array}{c}0.556 \\
(0.392)\end{array}$ & $\begin{array}{l}-0.024 \\
(0.677)\end{array}$ & $\begin{array}{l}-0.769 \\
(0.599)\end{array}$ \\
\hline HH size & $\begin{array}{c}6.556 \\
(2.425)\end{array}$ & $\begin{array}{c}6.508 \\
(2.471)\end{array}$ & $\begin{array}{c}6.514 \\
(2.433)\end{array}$ & $\begin{array}{c}6.437 \\
(2.496)\end{array}$ & $\begin{array}{c}6.574 \\
(2.491)\end{array}$ & $\begin{array}{c}-0.047 \\
(0.154)\end{array}$ & $\begin{array}{c}-0.077 \\
(0.257)\end{array}$ & $\begin{array}{c}0.060 \\
(0.246)\end{array}$ \\
\hline Female HH head $(0 / 1)$ & $\begin{array}{c}0.149 \\
(0.357)\end{array}$ & $\begin{array}{c}0.146 \\
(0.353)\end{array}$ & $\begin{array}{c}0.157 \\
(0.365)\end{array}$ & $\begin{array}{c}0.131 \\
(0.338)\end{array}$ & $\begin{array}{c}0.149 \\
(0.356)\end{array}$ & $\begin{array}{c}-0.004 \\
(0.020)\end{array}$ & $\begin{array}{l}-0.026 \\
(0.026)\end{array}$ & $\begin{array}{l}-0.008 \\
(0.030)\end{array}$ \\
\hline HH head education in years & $\begin{array}{c}9.038 \\
(5.256)\end{array}$ & $\begin{array}{c}9.230 \\
(5.291)\end{array}$ & $\begin{array}{c}9.245 \\
(5.520)\end{array}$ & $\begin{array}{c}8.982 \\
(5.243)\end{array}$ & $\begin{array}{c}9.467 \\
(5.092)\end{array}$ & $\begin{array}{c}0.192 \\
(0.361)\end{array}$ & $\begin{array}{l}-0.263 \\
(0.490)\end{array}$ & $\begin{array}{c}0.222 \\
(0.604)\end{array}$ \\
\hline $\mathrm{Nr}$ assets and livestock & $\begin{array}{c}6.034 \\
(2.922)\end{array}$ & $\begin{array}{c}6.076 \\
(3.105)\end{array}$ & $\begin{array}{c}6.129 \\
(3.267)\end{array}$ & $\begin{array}{c}5.924 \\
(3.097)\end{array}$ & $\begin{array}{c}6.176 \\
(2.936)\end{array}$ & $\begin{array}{c}0.042 \\
(0.270)\end{array}$ & $\begin{array}{c}-0.205 \\
(0.461)\end{array}$ & $\begin{array}{c}0.046 \\
(0.430)\end{array}$ \\
\hline
\end{tabular}

Notes: ${ }^{a}$ Test of mean difference based on a linear regression with standard errors clustered at the farmer group level. *** $\mathrm{p}<0.01, * * \mathrm{p}<0.05$,

$* \mathrm{p}<0.1$ 


\section{Pre-intervention balance}

Table 2.3 presents pre-intervention levels of variables for the treatment and control group households. Treatment households have lower harvest quality scores and coffee revenues per kilogramme but the differences are not significant at conventional levels. However, there is a large significant difference in high-value market participation between treatment and control group farmers. Treatment households have significantly lower levels of high-value market participation than the control households. To deal with the imbalances, we employ difference-indifferences estimator since comparing ex-post differences between the treatment and the control group would yield biased results (elaborated in the next subsection). We also present the pre-intervention differences between the second and third treatment groups against the first treatment group. The differences between T1 and T2 as well as T1 and T3 are also mostly negative but statistically insignificant.

\subsubsection{Estimation strategy}

Firstly, we seek to document the overall treatment effect of information delivered through extension on our outcome variables i.e. adoption of quality-improving practices, high-value market participation, and revenues earned per kilogramme of coffee harvested. Since all treatment groups received the same information, it is reasonable to make a general treatment-control comparison to analyse the effects of information. Secondly, we estimate the additional effect of the peer farmer treatment (T2) and the market actor treatment (T3) against the extension worker only treatment (T1) on the outcomes of interest.

We present intention-to-treat (ITT) effects i.e. the effect of being assigned to treatment ( not necessarily receiving the treatment). The ITT is particularly informative and interesting to policy makers regarding the overall effect of a programme because the assignment of a programme is what is in their control - they typically cannot force people to participate in and, in most cases, prevent people from receiving the treatment. To answer our first research question, i.e. is information a barrier to adoption of quality-improving practices, we estimate the effect of information provision treatment on our first outcome of interest, adoption measured by harvest quality score. We use ordinary least squares (OLS) and estimate the following:

$$
Y_{i g}=\alpha_{1}+\alpha_{2} T_{g}+X_{i g}^{\prime} \delta+\varepsilon_{i g}
$$


where $Y_{i g}$ is the outcome (harvest quality score) of household in farmer group $g$. $T$ is an indicator variable that takes the value 1 if group $g$ is assigned to treatment. $\varepsilon_{i g}$ is the error term clustered at the level of randomisation unit i.e. farmer group. Under the identifying assumption that $T$ is orthogonal to the error term (holds by random design and is shown in the pre-intervention balance table), the coefficient $\alpha_{2}$ measures the causal effect of the treatment assignment. $X_{i g}$ is a vector of covariates including coffee-quality-related variables such as if the coffee was attacked by pests and diseases before harvest in addition to experience with coffee farming in years, distance to nearest tarmac road in kilometers, household size, sex and education level of household head, number of extension meetings attended in the year before baseline data collection. Following the recommendations of Bruhn and McKenzie (2009), we include the baseline covariates which are used for stratification and which are correlated with our outcome variables in our regressions. In addition, since the correlation of the outcome variable (harvest quality score) between baseline and follow-up is low (0.36), we estimate the treatment effect using ANCOVA (Analysis of Covariance) which simply implies controlling for the baseline value of the outcome variable in the regression (McKenzie, 2012).

Additionally, we provide the average effect size (AES) across the components within the index-type score variables we have (i.e.harvest quality score) following Kling et al. (2007); Clingingsmith et al. (2009). AES accounts for the covariance across estimates of index components. AES compuation simply gives equal weight to all index components and calculates the average effect size using the seeminglyunrelated regression framework. For a family of $J$ related outcomes $Y^{j}$ in an index, with average treatment effects $\pi_{i}$, the average effect size is $\tau=\frac{1}{J} \sum_{j=1}^{J} \frac{\pi_{j}}{\sigma_{j}}$, where $\sigma_{j}$ is the standard deviation of outcome $j$ in the comparison group. The coefficients $\pi_{j}$ are the same as those estimated in the component-by-component regressions and the stacked AES regression gives the correct covariance matrix (Clingingsmith et al., 2009). We essentially compute the average effect size to test whether the effect is robust to accounting for the covariance across estimates of the items in the index.

Regarding high-value market participation, the observed baseline imbalance between the treatment and control group farmers effectively violates the identification of treatment effects and consequently the post-treatment difference between the treatment and control farmers is not unambigiously attributable to the treatment. Figure 2.2 visualises the pre- and post-intervention values of high-value 
market participation across treatment groups. In addition, because there is high correlation of the high-value market participation between baseline and followup, difference-in-difference (DiD) is our preferred approach (McKenzie, 2012). To estimate the treatment effect (ITT) we model the outcome variable $Y_{i}$ by the following equation:

$$
Y_{i}=\alpha+\beta T_{i}+\gamma t_{i}+\theta T_{i} * t_{i}+X_{i}^{\prime} \delta+v_{i}
$$

where $T_{i}$ is the treatment indicator and $\beta$ is treatment group specific effect, $t_{i}$ is the post-treatment indicator and $\gamma$ time trend common to control and treatment groups, $X_{i}$ is a vector of time-invariant baseline and time-varying covariates, $v_{i}$ is a random unobserved error term. $\theta$ is the true effect of treatment under the identifying assumption of "parallel trends" in that the difference between the treatment and control is constant absent the treatment. In our case, parallel trends basically requires that, despite the pre-intervention difference in the levels of highvalue market participation, the trend in high-value market participation would have been the same in the absence of the treatment.

Since we only have pre-intervention data at one point in time, we are unable to provide evidence that parallel trends assumption holds. However, Abadie (2005) argue that the parallel trends assumption could be valid if the two comparison groups are balanced on pre-treatment characteristics that are correlated with changes in the outcome of interest, high-value market participation. For instance, factors that affect market access such as distance to the nearest tarmac road and altitude in addition to variables that might be correlated with coffee quality (e.g. harvest quality, pest-disease attacks) are all balanced across treatment groups (Table 2.3). In addition, we are not aware of any shock which might have affected the randomly selected groups differenty. Hence, we believe that parallel trends assumption is likely to hold in that the difference in high-value market participation between treatment and control groups would have been the same in the absence of the treatment.

To analyse the treatment effect on coffee revenues earned per kilogramme, we estimate both OLS and DiD models. Farmers are price-takers and revenues earned depend on the marketing channel. Given that the baseline revenues of the treatment group is lower than that of the control group, which is in line with lower levels of high-value market participation, our preferred model for estimating treatment effects on revenues is the DiD model. Figure 2.3 shows the pre- and post- 
intervention values of revenues earned per kilogramme across treatment groups. Given that farmers are price takers, we do not expect a significant difference in the change in revenues earned per kilogramme of coffee harvest across treatment groups absent the treatment. In addition, we are not aware of any price shock which might have affected the randomly selected groups differently. Since baseline covariates which are related to market access and quality are balanced, the parallel trends assumption is likely to hold for coffee revenues earned.

To test the effects of the peer farmer and market actor treatments, we analyse the effect of peer farmer treatment (T2) and market actor treatment (T3) using the standard extension treatment group (T1) as a comparison group. Our main aim is to test the two alternative approaches against the standard approach and to assess the effect of the additional communicator (either the peer farmer or the market actor). Additionally, focusing on the additional effect of the communicator in comparison to the standard extension approach, allows us to address non-compliance, which is an issue in the control group. analysing the effects of T2 and T3 against $\mathrm{T} 1$ essentially drops the control group (that is contamined) from the analysis and allows for an analysis based on a sample with a higher compliance on average.

Figure 2.2: High-value market participation (\%) before and after the intervention

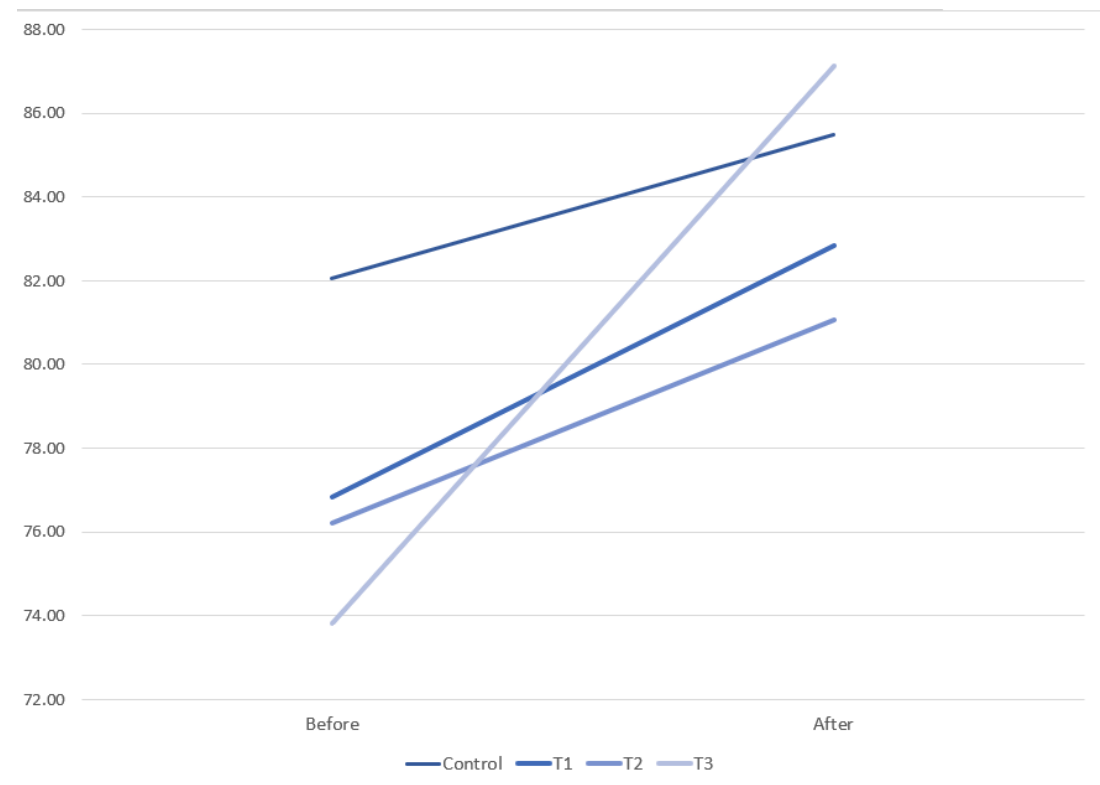

Since neither peer farmer nor market actor treatment was communicated to invited farmers in advance, $\mathrm{T} 1$ farmers could not have self-selected into attending the meetings of T2 or T3 (essentially the same meeting since they were not ex-ante aware of any difference). T1 farmers thus represent a clean comparison group for 
Figure 2.3: Revenues earned per $\mathrm{kg}$ in UShs before and after intervention

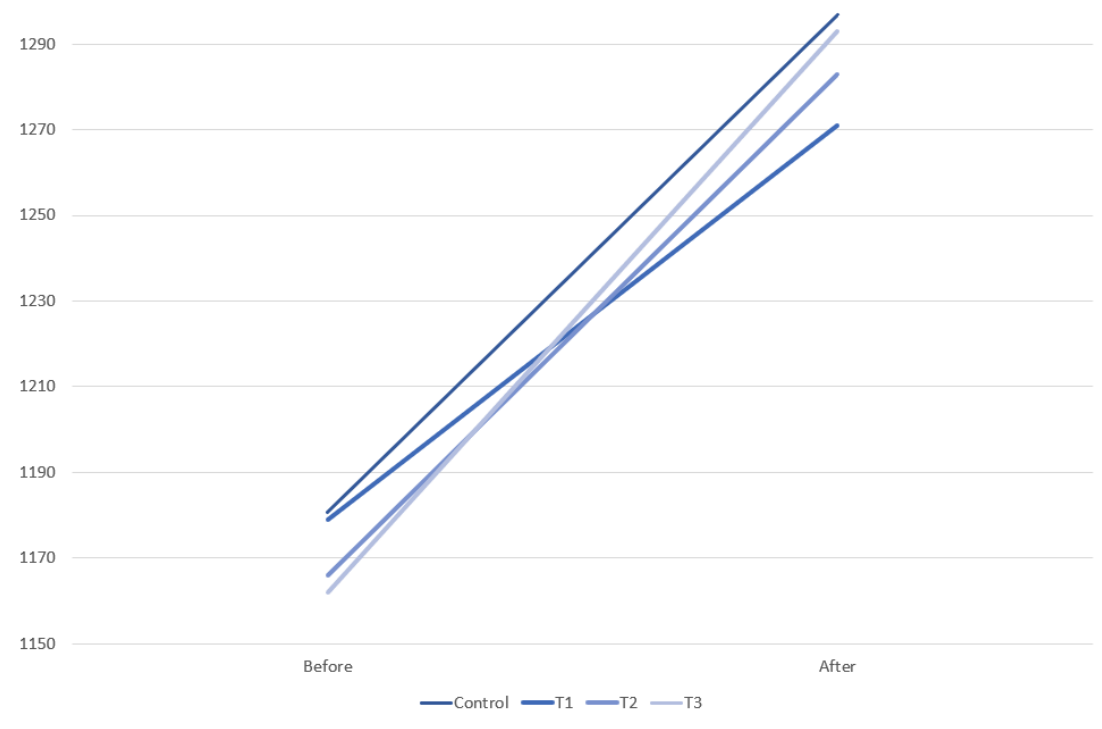

T2 and T3 treatment groups. Take-up rates across treatment groups do not significantly differ, which supports our argument that there is no non-random take-up in any of the treatment groups. We nonetheless present the results of the estimations wherein we regress outcome variables on three treatment indicators. However, an OLS model which includes all three treatment indicators cannot account for the large baseline imbalances, particularly in high-value market participation and potentially revenues (see Figure 2.2 and 2.3). Hence, we provide the results of $\mathrm{DiD}$ estimations for high-value market participation and revenues and OLS estimations for quality-improving practices (Table A.1).

\subsection{Results}

Firstly, we analyse the overall treatment effect of information delivered through extension on adoption of quality-improving practices, high-value market participation, and revenues earned per kilogramme of coffee harvested. Since all treatment groups received the same exact information, a general treatment-control comparison is made to analyse the effects of information provision. Secondly, we analyse the additional effect of the peer farmer treatment (T2) and the market actor treatment (T3) using the extension worker only treatment (T1) as a comparison group.

\subsubsection{Information provision treatment}

Table 2.4 summarises intention-to-treat (ITT) effects of information provision. Full specifications are presented in Table 2.10. Our first outcome of interest is adop- 
tion of quality-improving practices measured by harvest quality scores. Our results show that treatment households have 0.16 higher scores on harvest quality scores than control households (Column 3). Given that the mean outcome of the control group is 0.80 , the ITT effect translates into roughly 20 percent higher scores in the treatment group compared to the control group farmers. This implies that as a result of the training treatment households made more efforts to improve coffee quality harvested. In the bottom part of Table 2.4, we report average effect sizes (AES) of 0.17-0.18 units for harvest quality scores. AES essentially calculates the average effect after correcting for the standard errors between the items used to construct the harvest quality score. AES is relatively similar to but even higher than the average treatment effect estimated using ANCOVA indicating robustness of our estimates to accounting for the covariance across estimates of the components in the outcome variable.

Our second outcome of interest is high-value market participation. Recall that the baseline level of high-value market participation is significantly higher in the control than treatment group households. To account for the large imbalance between the treatment and control group in terms of baseline high-value market participation, we estimate treatment effects using difference-in-differences (DiD). Column 6 shows a positive coefficient on the interaction of post-treatment and treatment indicators (5 percentage points), but the coefficient is not statistically significant at conventional levels. Lastly, we present the treatment effects on coffee revenues earned per kilogramme of coffee harvested. Since farmers are price-takers, revenues earned highly depend on the marketing channel. Given that the baseline imbalances, treatment effects on revenues earned per kilogramme are also estimated using a DiD model. The coefficient on the interaction of post-treatment and treatment indicator (average treatment effect) is insignificant (Column 9). Note that the revenues we analyse is the payment made to farmers while buying the coffee. In high-value markets, there is usually another payment (price premium, bonus) made to farmers after the coffee has been processed, exported, cup tasted, and the price of the coffee has been determined. ${ }^{11}$

\footnotetext{
${ }^{11}$ The processors/exporters are not able to predict how much the coffee will be sold for until it is cup scored (tasted) by experts because coffee cup quality is the most important determinant of coffee prices in the high-value markets. It is typically difficult to visually assess the quality of coffee because complex physical and chemical transformations occur during processing of coffee cherries which are not visible to the naked eye.
} 
Table 2.4: Effects on harvest quality scores, high-value market participation, and revenues earned per $\mathrm{kg}$ (average prices)

\begin{tabular}{|c|c|c|c|c|c|c|c|c|c|}
\hline & \multicolumn{3}{|c|}{ Harvest quality score $(0-3)$} & \multicolumn{3}{|c|}{ High-value market participation (\%) } & \multicolumn{3}{|c|}{ Revenues per kg in UShs } \\
\hline & $\begin{array}{l}\text { OLS } \\
(1)\end{array}$ & $\begin{array}{l}\text { OLS } \\
(2)\end{array}$ & $\begin{array}{l}\text { OLS } \\
(3)\end{array}$ & $\begin{array}{l}\text { DiD } \\
\text { (4) }\end{array}$ & $\begin{array}{l}\text { DiD } \\
\text { (5) }\end{array}$ & $\begin{array}{l}\text { DiD } \\
\text { (6) }\end{array}$ & $\begin{array}{l}\text { DiD } \\
(7)\end{array}$ & $\begin{array}{l}\text { DiD } \\
(8)\end{array}$ & $\begin{array}{l}\text { DiD } \\
\text { (9) }\end{array}$ \\
\hline Assigned to Treatment & $\begin{array}{l}0.121 * * \\
(0.0509)\end{array}$ & $\begin{array}{l}0.151^{* * *} \\
(0.0458)\end{array}$ & $\begin{array}{l}0.164 * * * \\
(0.0469)\end{array}$ & $\begin{array}{l}-6.414 * * \\
(2.932)\end{array}$ & $\begin{array}{l}-6.594^{*} \\
(3.644)\end{array}$ & $\begin{array}{l}-5.776 \\
(4.014)\end{array}$ & $\begin{array}{l}-11.47 \\
(12.30)\end{array}$ & $\begin{array}{l}-7.323 \\
(22.21)\end{array}$ & $\begin{array}{l}-9.666 \\
(21.83)\end{array}$ \\
\hline Post Treatment & & & & $\begin{array}{c}3.444 \\
(2.561)\end{array}$ & $\begin{array}{l}6.400 * \\
(3.471)\end{array}$ & $\begin{array}{l}6.260^{*} \\
(3.473)\end{array}$ & $\begin{array}{c}116.1^{* * * *} \\
(19.79)\end{array}$ & $\begin{array}{c}130.8^{* * * *} \\
(28.36)\end{array}$ & $\begin{array}{c}131.7^{* * * *} \\
(28.34)\end{array}$ \\
\hline $\begin{array}{l}\text { Interaction } \\
\text { (Treatment*Post) }\end{array}$ & & & & $\begin{array}{c}4.584 \\
(3.069)\end{array}$ & $\begin{array}{c}5.268 \\
(3.975)\end{array}$ & $\begin{array}{c}5.364 \\
(4.021)\end{array}$ & $\begin{array}{l}-2.892 \\
(23.11)\end{array}$ & $\begin{array}{c}-4.254 \\
(29.60)\end{array}$ & $\begin{array}{l}-1.669 \\
(30.07)\end{array}$ \\
\hline Constant & $\begin{array}{l}0.801 * * * \\
(0.0374)\end{array}$ & $\begin{array}{l}0.926 * * * \\
(0.0872)\end{array}$ & $\begin{array}{l}1.082^{* * * *} \\
(0.187)\end{array}$ & $\begin{array}{c}82.05^{* * * *} \\
(2.311)\end{array}$ & $\begin{array}{l}92.41^{* * * *} \\
(5.475)\end{array}$ & $\begin{array}{c}101.2^{* * * *} \\
(6.712)\end{array}$ & $\begin{array}{l}1,181^{* * * *} \\
(9.563)\end{array}$ & $\begin{array}{c}1,291 * * * \\
(37.32)\end{array}$ & $\begin{array}{c}1,368^{* * * *} \\
(37.85)\end{array}$ \\
\hline Controls & & Yes & Yes & & Yes & Yes & & Yes & Yes \\
\hline Strata FE & & & Yes & & & Yes & & & Yes \\
\hline Observations & 1,522 & 1,522 & 1,522 & 3,044 & 2,370 & 2,370 & 3,044 & 2,370 & 2,370 \\
\hline R-squared & 0.010 & 0.082 & 0.097 & 0.012 & 0.063 & 0.075 & 0.064 & 0.100 & 0.110 \\
\hline Average Effect Size (AES) & $\begin{array}{l}0.147 * * \\
(0.057)\end{array}$ & $\begin{array}{c}0.167 * * * \\
(0.053)\end{array}$ & $\begin{array}{c}0.184 * * * \\
(0.053)\end{array}$ & & & & & & \\
\hline
\end{tabular}

Notes: Controls include the baseline value of the outcome variable, harvest in kilograms in the previous harvest season (2017), experience with coffee farming in years, if the coffee was attacked by pests or diseases before the harvest season (2018), extension meetings attended within the last 12 months of baseline survey date, household size, sex and education level of household head, total number of assets and livestock, distance to nearest tarmac road in kilometers, altitude region (lower, middle, and upper), and an indicator variable that takes the value 1 if the peer farmer treatment was not implemented and 0 otherwise. Specifications that include strata fixed-effects (FE) do not include the controls of education level of the household head, baseline harvest levels, and 3 altitude regions. Standard errors are clustered at the farmer group level and reported in parentheses. $* * * \mathrm{p}<0.01, * * \mathrm{p}<0.05, * \mathrm{p}<0.1$ 
In our context, the exporter is responsible for returning the price premium to growers after exporting the coffee as well. Returned premium is not in the form of cash payment, however. The exporter provided biogas and pruning knives in the past and recently conducts community projects, such as building schools. Despite that there is an additional benefit in participating in high-value markets it is not directly paid to the individual farmer. This likely reduces the incentives to improve coffee quality and participate in high-value markets at the grower level.

\subsubsection{Effects of the peer farmer treatment}

Table 2.5 summarises the effects of the peer farmer treatment (T2) on our outcomes of interest. Full specifications are presented in Table 2.11, 2.12, and 2.13. We analyse the effect of peer farmer treatment (T2) using the standard extension treatment group (T1) as a comparison group. Our hypothesis is that treatment groups who were exposed to the information provided by a peer farmer, a plausibly more effective source of information about quality-improving practices, adopt quality-improving practices to a larger extent than those in the extensionworker-only groups (T1). In line with our hypothesis, we find that inclusion of a peer farmer in the extension approach significantly increases adoption of qualityimproving practices. Average treatment effect estimates show that T2 farmers have 0.3 units higher harvest quality score than $\mathrm{T} 1$ farmers (Column 3 ). This effect corresponds to roughly 30 percent higher harvest quality scores in T2 group than T1 group. This implies that incorporating a peer farmer in standard extension approaches encourages further adoption of product quality-improving practices and also that (persuasive) effectiveness of communicator the is indeed one of the barriers to coffee quality improvements. The effect of assignment to the peer farmer treatment on high-value market participation estimated using ANCOVA appears statistically insignificant (Column 5-6). DiD estimations, accounting for the baseline differences, however, show positive effects (5 percentage points). Quality improvements and, albeit to a limited extent, higher engagement with high-value markets lead to higher coffee revenues earned. The treatment effect estimated using ANCOVA on revenues is positive and significant. The coefficient translates into 34 UShs (0.10 USD) higher revenues per kilogramme earned by T2 farmers than $\mathrm{T} 1$ farmers. The treatment effect estimated using DiD estimator is in line with that of ANCOVA. 
Table 2.5: Effects of peer farmer treatment (T2) against T1

\begin{tabular}{|c|c|c|c|c|c|c|c|c|c|c|c|c|c|c|c|}
\hline & \multicolumn{3}{|c|}{ Harvest quality score $(0-3)$} & \multicolumn{6}{|c|}{ High-value market participation (\%) } & \multicolumn{6}{|c|}{ Revenues per $\mathrm{kg}$ in UShs } \\
\hline & $\begin{array}{l}\text { OLS } \\
(1)\end{array}$ & $\begin{array}{l}\text { OLS } \\
(2)\end{array}$ & $\begin{array}{l}\text { OLS } \\
(3)\end{array}$ & $\begin{array}{l}\text { OLS } \\
\text { (4) }\end{array}$ & $\begin{array}{l}\text { OLS } \\
(5)\end{array}$ & $\begin{array}{l}\text { OLS } \\
(6)\end{array}$ & $\begin{array}{l}\mathrm{DiD} \\
(7)\end{array}$ & $\begin{array}{l}\mathrm{DiD} \\
(8)\end{array}$ & $\begin{array}{l}\mathrm{DiD} \\
(9)\end{array}$ & $\begin{array}{l}\text { OLS } \\
(10)\end{array}$ & $\begin{array}{l}\text { OLS } \\
(11)\end{array}$ & $\begin{array}{l}\text { OLS } \\
(12)\end{array}$ & $\begin{array}{l}\mathrm{DiD} \\
(13)\end{array}$ & $\begin{array}{l}\mathrm{DiD} \\
(14)\end{array}$ & $\begin{array}{l}\mathrm{DiD} \\
(15)\end{array}$ \\
\hline $\begin{array}{l}\text { Assigned to T2 } \\
\text { Post T2 } \\
\text { Interaction } \\
\text { (T2*Post) }\end{array}$ & $\begin{array}{c}0.0246 \\
(0.0862)\end{array}$ & $\begin{array}{l}0.184 * * \\
(0.0699)\end{array}$ & $\begin{array}{l}0.300 * * * * \\
(0.0591)\end{array}$ & $\begin{array}{c}-1.764 \\
(4.870)\end{array}$ & $\begin{array}{c}-2.213 \\
(4.250)\end{array}$ & $\begin{array}{c}-2.547 \\
(4.116)\end{array}$ & $\begin{array}{l}-0.641 \\
(4.532) \\
5.985^{* *} \\
(2.328) \\
-1.124 \\
(4.206)\end{array}$ & $\begin{array}{c}-6.713 \\
(5.433) \\
5.839 \\
(3.482) \\
6.631 \\
(5.287)\end{array}$ & $\begin{array}{c}-7.329^{*} \\
(4.119) \\
6.625^{*} \\
(3.508) \\
5.363 \\
(5.368)\end{array}$ & $\begin{array}{c}12.10 \\
(22.96)\end{array}$ & $\begin{array}{l}38.99^{*} \\
(20.22)\end{array}$ & $\begin{array}{l}34.23 * \\
(18.15)\end{array}$ & $\begin{array}{c}-12.09 \\
(18.76) \\
92.61^{* * *} \\
(17.43) \\
24.19 \\
(25.73)\end{array}$ & $\begin{array}{c}4.232 \\
(31.34) \\
89.53^{* * *} \\
(23.40) \\
33.28 \\
(34.56)\end{array}$ & $\begin{array}{c}5.166 \\
(27.50) \\
97.43^{* * *} \\
(23.20) \\
30.16 \\
(34.81)\end{array}$ \\
\hline Constant & $\begin{array}{l}0.921 * * * * \\
(0.0595)\end{array}$ & $\begin{array}{c}0.911 * * * \\
(0.149)\end{array}$ & $\begin{array}{c}0.990 * * * \\
(0.304)\end{array}$ & $\begin{array}{c}82.83 * * * * \\
(3.102)\end{array}$ & $\begin{array}{c}80.51^{* * * *} \\
(6.849)\end{array}$ & $\begin{array}{c}83.23 * * * * \\
(5.423)\end{array}$ & $\begin{array}{c}76.84 * * * \\
(2.929)\end{array}$ & $\begin{array}{c}101.4^{* * * *} \\
(6.342)\end{array}$ & $\begin{array}{c}109.0 * * * * \\
(5.811)\end{array}$ & $\begin{array}{c}1,271 * * * \\
(13.07)\end{array}$ & $\begin{array}{c}1,316^{* * * *} \\
(81.75)\end{array}$ & $\begin{array}{c}1,363 * * * * \\
(81.46)\end{array}$ & $\begin{array}{c}1,179 * * * * \\
(14.51)\end{array}$ & $\begin{array}{c}1,330 * * * \\
(42.10)\end{array}$ & $\begin{array}{r}1,394 * * \\
(40.11)\end{array}$ \\
\hline $\begin{array}{l}\text { Controls } \\
\text { Strata FE } \\
\text { Observations } \\
\text { R-squared }\end{array}$ & $\begin{array}{c}677 \\
0.000\end{array}$ & $\begin{array}{c}\text { Yes } \\
\\
677 \\
0.137\end{array}$ & $\begin{array}{c}\text { Yes } \\
\text { Yes } \\
677 \\
0.172\end{array}$ & $\begin{array}{c}677 \\
0.001\end{array}$ & $\begin{array}{c}\text { Yes } \\
677 \\
0.104\end{array}$ & $\begin{array}{c}\text { Yes } \\
\text { Yes } \\
677 \\
0.144\end{array}$ & $\begin{array}{l}1,354 \\
0.006\end{array}$ & $\begin{array}{c}\text { Yes } \\
1,069 \\
0.086\end{array}$ & $\begin{array}{c}\text { Yes } \\
\text { Yes } \\
1,069 \\
0.131\end{array}$ & $\begin{array}{c}677 \\
0.001\end{array}$ & $\begin{array}{c}\text { Yes } \\
677 \\
0.045\end{array}$ & $\begin{array}{c}\text { Yes } \\
\text { Yes } \\
677 \\
0.061\end{array}$ & $\begin{array}{l}1,354 \\
0.056\end{array}$ & $\begin{array}{c}\text { Yes } \\
1,069 \\
0.097\end{array}$ & $\begin{array}{c}\text { Yes } \\
\text { Yes } \\
1,069 \\
0.116\end{array}$ \\
\hline
\end{tabular}

Notes: Controls include the baseline value of the outcome variable, harvest in kilograms in the previous harvest season (2017), experience with coffee farming in years, if the coffee was attacked by pests or

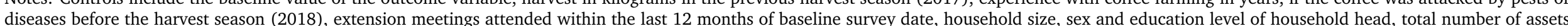

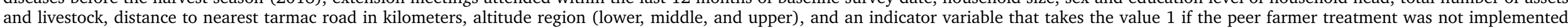

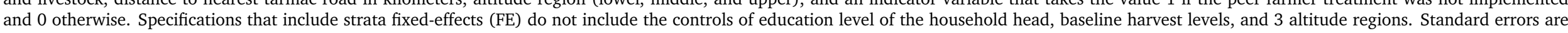
clustered at the farmer group level and reported in parentheses. ${ }^{* * *} \mathrm{p}<0.01,{ }^{* *} \mathrm{p}<0.05,{ }^{*} \mathrm{p}<0.1$ 


\subsubsection{Effects of the market actor treatment}

Table 2.6 summarises the effects of the high-status market actor treatment (T3) on the outcomes of interest. Full specifications are presented in Table 2.11, 2.12, and 2.13. Our estimations show that the difference in harvest quality scores between T1 and T3 groups is not significantly different from zero (Column 3). We do find a significant treatment effect on high-value market participation, however. Market actor treatment (T3) households participate in high-value markets significantly (7.4 percentage points) more than the T1 households (Column 6). The coefficient is significant at the 5 percent level. The results of DiD estimations, which take baseline differences into account, are also provided. The coefficient of the interaction term between the treatment indicator and post treatment indicator is about 50 percent higher than that of the ANCOVA model and equally significant. In particular, high-value market participation of T3 households is 11.5 percentage points higher than T1 households. In line with our hypothesis, we find evidence that information about markets provided by a high-status market actor, a plausibly more persuasive communicator based on the attributes of competence and trustworthiness, causes a large and significant increase in high-value market participation. Persuasive effectiveness of the communicator of market-related information appears to be a barrier to higher participation in high-value markets.

Regarding revenues earned per kilogramme of coffee harvested, ANCOVA estimations show an effect of 31 UShs (very similar to the price effect of T2) but the coefficient is not statistically significant. However, baseline high-value market participation of T3 group farmers is lower than that of T1 farmers. As a result, DiD estimations show that high-status market actor treatment households receive higher prices 63 UShs per kilogramme of coffee than that of T1 households (Column 15). This difference translates to approximately 20 USD increase in total coffee revenues for the average coffee grower.

A comparison of the effects of T2 and T3 indicates that farmers in the market actor treatment have significantly lower harvest quality scores, while significantly higher high-value market participation than those in the peer farmer treatment (Table 2.7). These results support our argument that a peer farmer is an effective source of quality-related information, whereas a high-status market actor is a persuasive source of market-related information. Revenues earned per kilogramme are higher for the market actor treatment households than that for the peer farmer treatment households but the difference is not significantly different than zero. 
Table 2.6: Effects of high-status market actor treatment (T3) against T1

\begin{tabular}{|c|c|c|c|c|c|c|c|c|c|c|c|c|c|c|c|}
\hline & \multicolumn{3}{|c|}{ Harvest quality score $(0-3)$} & \multicolumn{6}{|c|}{ High-value market participation (\%) } & \multicolumn{6}{|c|}{ Revenues per kg in UShs } \\
\hline & $\begin{array}{l}\text { OLS } \\
(1)\end{array}$ & $\begin{array}{l}\text { OLS } \\
(2)\end{array}$ & $\begin{array}{l}\text { OLS } \\
\text { (3) }\end{array}$ & $\begin{array}{l}\text { OLS } \\
\text { (4) }\end{array}$ & $\begin{array}{l}\text { OLS } \\
(5)\end{array}$ & $\begin{array}{l}\text { OLS } \\
\text { (6) }\end{array}$ & $\begin{array}{l}\mathrm{DiD} \\
(7)\end{array}$ & $\begin{array}{l}\mathrm{DiD} \\
(8)\end{array}$ & $\begin{array}{l}\mathrm{DiD} \\
(9)\end{array}$ & $\begin{array}{l}\text { OLS } \\
(10)\end{array}$ & $\begin{array}{l}\text { OLS } \\
(11)\end{array}$ & $\begin{array}{l}\text { OLS } \\
(12)\end{array}$ & $\begin{array}{l}\mathrm{DiD} \\
\text { (13) }\end{array}$ & $\begin{array}{l}\mathrm{DiD} \\
(14)\end{array}$ & $\begin{array}{l}\mathrm{DiD} \\
\text { (15) }\end{array}$ \\
\hline $\begin{array}{l}\text { Assigned to T3 } \\
\text { Post T3 } \\
\text { Interaction } \\
\text { (T3*Post) }\end{array}$ & $\begin{array}{c}-0.0198 \\
(0.0837)\end{array}$ & $\begin{array}{c}0.0101 \\
(0.0739)\end{array}$ & $\begin{array}{l}0.00284 \\
(0.0652)\end{array}$ & $\begin{array}{c}4.290 \\
(3.587)\end{array}$ & $\begin{array}{l}5.311^{*} \\
(2.911)\end{array}$ & $\begin{array}{l}7.399 * * \\
(2.920)\end{array}$ & $\begin{array}{l}-3.030 \\
(4.164) \\
5.985^{* *} \\
(2.328) \\
7.320^{* *} \\
(3.433)\end{array}$ & $\begin{array}{c}-7.565^{*} \\
(4.383) \\
5.179 \\
(3.486) \\
11.45^{* *} \\
(4.689)\end{array}$ & $\begin{array}{c}-6.678^{*} \\
(3.945) \\
5.000 \\
(3.352) \\
11.49^{* *} \\
(4.716)\end{array}$ & $\begin{array}{c}22.38 \\
(26.33)\end{array}$ & $\begin{array}{c}26.16 \\
(21.22)\end{array}$ & $\begin{array}{c}30.98 \\
(21.46)\end{array}$ & $\begin{array}{c}-15.92 \\
(19.86) \\
92.61 * * * \\
(17.43) \\
38.30 \\
(30.34)\end{array}$ & $\begin{array}{c}-44.70 \\
(27.89) \\
93.28^{* * *} \\
(23.96) \\
64.03^{*} \\
(35.87)\end{array}$ & $\begin{array}{r}-40.09 \\
(26.93) \\
100.3^{* * *} \\
(23.85) \\
62.66^{*} \\
(35.88)\end{array}$ \\
\hline Constant & $\begin{array}{l}0.921^{* * * *} \\
(0.0595)\end{array}$ & $\begin{array}{c}0.985^{* * * *} \\
(0.146)\end{array}$ & $\begin{array}{c}1.523 * * * \\
(0.100)\end{array}$ & $\begin{array}{c}82.83 * \cdots * * \\
(3.102)\end{array}$ & $\begin{array}{c}70.76 * * * * \\
(8.809)\end{array}$ & $\begin{array}{c}78.34 * * * * \\
(7.282)\end{array}$ & $\begin{array}{c}76.84^{* * * * *} \\
(2.929)\end{array}$ & $\begin{array}{c}97.18 * * * * \\
(7.637)\end{array}$ & $\begin{array}{c}105.8 * * * * \\
(7.392)\end{array}$ & $\begin{array}{c}1,271 * * * * \\
(13.07)\end{array}$ & $\begin{array}{c}1,200 * * * * * \\
(82.89)\end{array}$ & $\begin{array}{c}1,267 * \frac{* * * *}{*} \\
(87.14)\end{array}$ & $\begin{array}{c}1,179 * * * * \\
(14.51)\end{array}$ & $\begin{array}{c}1,290 * * * * \\
(47.71)\end{array}$ & $\begin{array}{r}1,396 * * \\
(40.54)\end{array}$ \\
\hline $\begin{array}{l}\text { Controls } \\
\text { Strata FE }\end{array}$ & & Yes & $\begin{array}{l}\text { Yes } \\
\text { Yes }\end{array}$ & & Yes & $\begin{array}{l}\text { Yes } \\
\text { Yes }\end{array}$ & & Yes & $\begin{array}{l}\text { Yes } \\
\text { Yes }\end{array}$ & & Yes & $\begin{array}{l}\text { Yes } \\
\text { Yes }\end{array}$ & & Yes & $\begin{array}{l}\text { Yes } \\
\text { Yes }\end{array}$ \\
\hline $\begin{array}{l}\text { Observations } \\
\text { R-squared }\end{array}$ & $\begin{array}{c}677 \\
0.000\end{array}$ & $\begin{array}{c}677 \\
0.066\end{array}$ & $\begin{array}{c}677 \\
0.119\end{array}$ & $\begin{array}{c}677 \\
0.004\end{array}$ & $\begin{array}{c}677 \\
0.094\end{array}$ & $\begin{array}{c}677 \\
0.114\end{array}$ & $\begin{array}{l}1,354 \\
0.019\end{array}$ & $\begin{array}{l}1,068 \\
0.095\end{array}$ & $\begin{array}{l}1,068 \\
0.118\end{array}$ & $\begin{array}{c}677 \\
0.002\end{array}$ & $\begin{array}{c}677 \\
0.053\end{array}$ & $\begin{array}{c}677 \\
0.053\end{array}$ & $\begin{array}{l}1,354 \\
0.062\end{array}$ & $\begin{array}{l}1,068 \\
0.123\end{array}$ & $\begin{array}{l}1,068 \\
0.125\end{array}$ \\
\hline
\end{tabular}

Notes: Controls include the baseline value of the outcome variable, harvest in kilograms in the previous harvest season (2017), experience with coffee farming in years, if the coffee was attacked by pests or diseases before the harvest season (2018), extension meetings attended within the last 12 months of baseline survey date, household size, sex and education level of household head, total number of assets and livestock, distance to nearest tarmac road in kilometers, and 3 altitude regions. Specifications that include strata fixed-effects (FE) do not include the controls of education level of the household head, baseline harvest levels, and 3 altitude regions. Standard errors are clustered at the farmer group level and reported in parentheses.**** $\mathrm{p}<0.01, * * \mathrm{p}<0.05,{ }^{*} \mathrm{p}<0.1$ 
Table 2.7: Effects of high-status market actor treatment (T3) against peer farmer treatment (T2)

\begin{tabular}{|c|c|c|c|c|c|c|c|c|c|c|c|c|c|c|c|}
\hline & \multicolumn{3}{|c|}{ Harvest quality score (0-3) } & \multicolumn{6}{|c|}{ High-value market participation (\%) } & \multicolumn{6}{|c|}{ Revenues per kg in UShs } \\
\hline & $\begin{array}{l}\text { OLS } \\
\text { (1) }\end{array}$ & $\begin{array}{l}\text { OLS } \\
\text { (2) }\end{array}$ & $\begin{array}{l}\text { OLS } \\
\text { (3) }\end{array}$ & $\begin{array}{l}\text { OLS } \\
(4)\end{array}$ & $\begin{array}{l}\text { OLS } \\
\text { (5) }\end{array}$ & $\begin{array}{l}\text { OLS } \\
\text { (6) }\end{array}$ & $\begin{array}{l}\mathrm{DiD} \\
(7)\end{array}$ & $\begin{array}{l}\mathrm{DiD} \\
(8)\end{array}$ & $\begin{array}{l}\mathrm{DiD} \\
(9)\end{array}$ & $\begin{array}{l}\text { OLS } \\
(10)\end{array}$ & $\begin{array}{l}\text { OLS } \\
\text { (11) }\end{array}$ & $\begin{array}{l}\text { OLS } \\
\text { (12) }\end{array}$ & $\begin{array}{l}\mathrm{DiD} \\
(13)\end{array}$ & $\begin{array}{l}\mathrm{DiD} \\
(14)\end{array}$ & $\begin{array}{l}\mathrm{DiD} \\
(15)\end{array}$ \\
\hline $\begin{array}{l}\text { Assigned to T3 } \\
\text { Post T3 } \\
\text { Interaction } \\
\text { (T3*Post) }\end{array}$ & $\begin{array}{c}-0.0444 \\
(0.0857)\end{array}$ & $\begin{array}{l}-0.159^{* * *} \\
(0.0745)\end{array}$ & $\begin{array}{c}-0.286 * * * * \\
(0.0341)\end{array}$ & $\begin{array}{c}6.054 \\
(4.167)\end{array}$ & $\begin{array}{c}6.381 \\
(3.973)\end{array}$ & $\begin{array}{c}11.85^{* * * *} \\
(3.267)\end{array}$ & $\begin{array}{c}-2.390 \\
(4.555) \\
4.861 \\
(3.506) \\
8.444^{*} \\
(4.321)\end{array}$ & $\begin{array}{c}-2.331 \\
(5.505) \\
11.27 * * \\
(4.241) \\
6.301 \\
(5.323)\end{array}$ & $\begin{array}{c}1.721 \\
(4.916) \\
9.845^{* *} \\
(4.247) \\
7.405 \\
(5.307)\end{array}$ & $\begin{array}{c}10.28 \\
(29.67)\end{array}$ & $\begin{array}{l}-17.24 \\
(26.53)\end{array}$ & $\begin{array}{c}1.915 \\
(28.86)\end{array}$ & $\begin{array}{c}-3.823 \\
(18.04) \\
116.8 * * * \\
(18.94) \\
14.11 \\
(31.25)\end{array}$ & $\begin{array}{c}-45.86 \\
(34.54) \\
127.9 * * * \\
(28.02) \\
25.54 \\
(38.90)\end{array}$ & $\begin{array}{c}-20.41 \\
(34.52) \\
133.7^{* * * *} \\
(28.92) \\
20.78 \\
(39.08)\end{array}$ \\
\hline Constant & $\begin{array}{l}0.945 * * * \\
(0.0624)\end{array}$ & $\begin{array}{c}1.157^{* * * * *} \\
(0.136)\end{array}$ & $\begin{array}{c}0.998^{* * * * *} \\
(0.107)\end{array}$ & $\begin{array}{c}81.07 \div * * * \\
(3.757)\end{array}$ & $\begin{array}{c}61.92^{* * * *} \\
(8.755)\end{array}$ & $\begin{array}{c}74.18^{* * * *} \\
(5.574)\end{array}$ & $\begin{array}{c}76.20 * \cdots * * \\
(3.461)\end{array}$ & $\begin{array}{c}75.04 * * * * \\
(5.856)\end{array}$ & $\begin{array}{c}84.79 * * * * \\
(6.111)\end{array}$ & $\begin{array}{c}1,283 * * * * \\
(18.89)\end{array}$ & $\begin{array}{c}1,257 \div * * * \\
(65.69)\end{array}$ & $\begin{array}{c}1,243 * * * * * 3^{*} \\
(62.90)\end{array}$ & $\begin{array}{c}1,166^{* * * * *} \\
(11.90)\end{array}$ & $\begin{array}{c}1,259 * * * * \\
(51.11)\end{array}$ & $\begin{array}{c}1,304 * * * * * \\
(34.91)\end{array}$ \\
\hline $\begin{array}{l}\text { Controls } \\
\text { Strata FE } \\
\text { Observations } \\
\text { R-squared }\end{array}$ & $\begin{array}{c}666 \\
0.001\end{array}$ & $\begin{array}{c}\text { Yes } \\
666 \\
0.118\end{array}$ & $\begin{array}{c}\text { Yes } \\
\text { Yes } \\
666 \\
0.179\end{array}$ & $\begin{array}{c}666 \\
0.008\end{array}$ & $\begin{array}{c}\text { Yes } \\
666 \\
0.094\end{array}$ & $\begin{array}{c}\text { Yes } \\
\text { Yes } \\
666 \\
0.139\end{array}$ & $\begin{array}{l}1,332 \\
0.019\end{array}$ & $\begin{array}{c}\text { Yes } \\
1,041 \\
0.087\end{array}$ & $\begin{array}{c}\text { Yes } \\
\text { Yes } \\
1,041 \\
0.136\end{array}$ & $\begin{array}{c}666 \\
0.000\end{array}$ & $\begin{array}{c}\text { Yes } \\
666 \\
0.074\end{array}$ & $\begin{array}{c}\text { Yes } \\
\text { Yes } \\
666 \\
0.092\end{array}$ & $\begin{array}{l}1,332 \\
0.074\end{array}$ & $\begin{array}{c}\text { Yes } \\
1,041 \\
0.135\end{array}$ & $\begin{array}{c}\text { Yes } \\
\text { Yes } \\
1,041 \\
0.139\end{array}$ \\
\hline
\end{tabular}

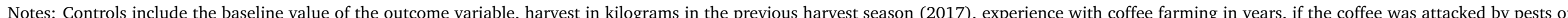

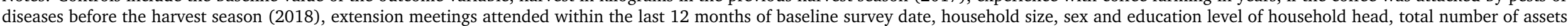

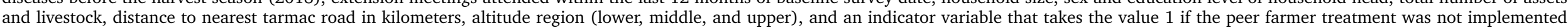

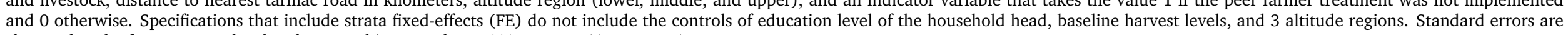
clustered at the farmer group level and reported in parentheses. ${ }^{* * *} \mathrm{p}<0.01, * * \mathrm{p}<0.05, * \mathrm{p}<0.1$ 


\section{Robustness check: other reasons why a market actor might be effective}

Additionally, we seek to explore potential mechanisms other than the persuasiveness of information through which the extension meetings that the high-status market actor attended resulted in higher high-value market participation. Results are summarised in Table 2.8. One potential explanation for a stronger effect is that extension workers might have made more effort to explain the importance of highvalue market participation during the meeting due to the presence of the highstatus market actor. Although we cannot test this directly, we can test whether perceived trainer (extension worker) quality is higher by farmers in the market actor treatment group. We fail to detect any significant difference in trainer ratings betweeen the T3 group farmers and the farmers in the other treatment arms (Column 1 and 2). In other words, extension workers in the market actor treatment group are not rated better by farmers than the extension workers in the other meetings.

Secondly, one might argue that contact with the manager of the largest exporter might change perceptions towards the company which then manifests itself in preferences to sell to the exporter. This is not necessarily related to the information provided but more about the perceptions towards the company represented by a high-level manager in the meetings (e.g. increased trust and/or reduced social distance). Although it is not possible for us to disentangle the effect of solely contacting the high-status market actor from that of the information he communicates, we do not find any significant difference between the T3 farmers and other treatment farmers in perceptions, such as trust in the company (Column 4), perceived trustworthiness of the company (Column 6) or how close the farmer feels to the company (Column 8) thereby potentially ruling out this channel. Note that extension workers are also employed by and thus represent the company.

Thirdly, Charness and Dufwenberg (2006) find evidence that behaviours are affected by beliefs about beliefs of others and argue that people strive to live up to others' expectations. Directly hearing from a high-level manager that coffee growers should improve coffee quality and benefit from high-value markets, growers may become aware of and strive to live up to the expectations of the manager who represents the company. However, we find no significant difference in growers' awareness of what the company expects. 
Table 2.8: Effect of market actor treatment (T3) on perceptions towards the exporter

\begin{tabular}{|c|c|c|c|c|c|c|c|c|c|c|c|c|}
\hline & \multicolumn{2}{|c|}{$\begin{array}{l}\text { How would you rate the } \\
\text { extension worker? } \\
\qquad(1-5)\end{array}$} & \multicolumn{2}{|c|}{$\begin{array}{l}\text { I trust the exporter } \\
\text { as a coffeebuyer } \\
(1-5)\end{array}$} & \multicolumn{2}{|c|}{$\begin{array}{c}\text { The exporter } \\
\text { is trustworthy } \\
(1-5)\end{array}$} & \multicolumn{2}{|c|}{$\begin{array}{l}\text { I feel } \\
\text { close to the exporter } \\
(1-5)\end{array}$} & \multicolumn{2}{|c|}{$\begin{array}{c}\text { The exporter expects to } \\
\text { buy highest quality coffee } \\
\text { (1-5) }\end{array}$} & \multicolumn{2}{|c|}{$\begin{array}{l}\text { The exporter expects me to } \\
\text { improve quality of my coffee } \\
(1-5)\end{array}$} \\
\hline & (1) & (2) & (3) & (4) & (5) & (6) & (7) & (8) & (9) & (10) & (11) & (12) \\
\hline Assigned to T3 & $\begin{array}{l}-0.0789 \\
(0.0629)\end{array}$ & $\begin{array}{c}-0.0520 \\
(0.0544)\end{array}$ & $\begin{array}{l}-0.0347 \\
(0.0688)\end{array}$ & $\begin{array}{c}0.0107 \\
(0.0643)\end{array}$ & $\begin{array}{c}0.0273 \\
(0.0897)\end{array}$ & $\begin{array}{c}0.0745 \\
(0.0786)\end{array}$ & $\begin{array}{c}0.0887 \\
(0.0705)\end{array}$ & $\begin{array}{c}0.0950 \\
(0.0700)\end{array}$ & $\begin{array}{l}-0.0549 \\
(0.0535)\end{array}$ & $\begin{array}{c}-0.0402 \\
(0.0471)\end{array}$ & $\begin{array}{c}-0.117 \\
(0.0766)\end{array}$ & $\begin{array}{c}-0.104 \\
(0.0622)\end{array}$ \\
\hline Constant & $\begin{array}{l}4.534 * * * \\
(0.0424)\end{array}$ & $\begin{array}{c}4.933 * * * \\
(0.408)\end{array}$ & $\begin{array}{l}3.990 * * * \\
(0.0410)\end{array}$ & $\begin{array}{c}4.227 * * * \\
(0.401)\end{array}$ & $\begin{array}{l}3.744 * * * \\
(0.0566)\end{array}$ & $\begin{array}{c}5.057 * * * \\
(0.557)\end{array}$ & $\begin{array}{l}3.824 * * * \\
(0.0503)\end{array}$ & $\begin{array}{c}5.446 * * * \\
(0.514)\end{array}$ & $\begin{array}{l}4.403 * * * \\
(0.0325)\end{array}$ & $\begin{array}{c}5.013 * * * \\
(0.360)\end{array}$ & $\begin{array}{l}4.168^{* * *} \\
(0.0358)\end{array}$ & $\begin{array}{c}5.309 * * * \\
(0.429)\end{array}$ \\
\hline Controls & & Yes & & Yes & & Yes & & Yes & & Yes & & Yes \\
\hline Observations & 595 & 595 & 1,010 & 1,010 & 1,010 & 1,010 & 1,010 & 1,010 & 1,010 & 1,010 & 1,010 & 1,010 \\
\hline R-squared & 0.004 & 0.091 & 0.000 & 0.032 & 0.000 & 0.037 & 0.002 & 0.052 & 0.002 & 0.061 & 0.006 & 0.048 \\
\hline
\end{tabular}

Notes: OLS estimations. Controls include the baseline value of the outcome variable, harvest in kilograms in the previous harvest season (2017), experience with coffee farming in years, if the coffee was attacked by pests or diseases before the harvest season (2018), extension meetings attended within the last 12 months of baseline survey date, household size, sex and education level of household head, total number of assets and livestock, distance to nearest tarmac road in kilometers, and 3 altitude regions. Standard errors are clustered at the farmer group level and reported in parentheses. ${ }^{* * *} \mathrm{p}<0.01, * * \mathrm{p}<0.05, * \mathrm{p}<0.1$ 
In particular, there is no significant difference between T3 farmers and other treatment farmers in their agreement with the statements that the exporter expects to buy highest quality coffee from them (Column 10) or that the exporter expects farmers to improve the quality of their coffee (Column 12). Results imply that farmers in market actor treatment group participate more in the high-value markets but this is not because of their perceptions about the company or the perceived expectations of the company. These findings provide support to our argument that the higher levels of participation in high-value markets are influenced by who communicates the information, given that the information is identical across treatments.

\subsubsection{Do quality and high-value market participation explain revenues?}

Estimations of treatment effects show small but positive effects on revenues earned per kilogramme. In this subsection, we shed light on the relative contributions of quality-improvements and high-value market participation to coffee revenues earned by the growers regardless of the treatment assignment and more in an exploratory fashion. We run first-difference (FD) estimations to see the extent to which changes in harvest quality score and high-value market participation explain the revenues earned. ${ }^{12}$

FD estimators deal with omitted time-invariant variable bias to a large extent since we difference out the unobserved time-invariant heterogeneity. Pooled OLS estimation results are presented in Table 2.9. Results show that the changes in harvest quality score significantly explain the revenues earned per kilogramme (Column 1). Revenues earned per kilogramme can also be significantly explained by participation in high-value markets (Column 1). Inclusion of both variables and timevarying controls does not substantially change the magnitude or significance of the coefficients. A sub-group analysis shows that changes in harvest quality can significantly explain the changes in revenues for households who participate in high-value markets (Column 3) but not for those who do not participate in highvalue markets at all (Column 4) although the sample size for the latter is small. Nonetheless, our findings support the argument that improving harvest quality should be complemented with high-value market participation to earn higher revenues. This is in line with our pre-intervention expectations and the findings of

\footnotetext{
${ }^{12}$ Note, however, that in the baseline data we do not have all the variables that we use to construct the harvest quality score. For this reason, in our FD estimation we only use the one variable available in both baseline and follow-up data.
} 
Wollni and Zeller (2007) that participation in high-value markets is associated with higher coffee revenues and that in conventional markets quality tends not to be remunerated.

Table 2.9: First-difference (FD) estimations

\begin{tabular}{|c|c|c|c|c|}
\hline & Revel & le per kg (a & rage prices & UShs \\
\hline & & & & No \\
\hline & & & HV MP & HV MP \\
\hline & (1) & (2) & (3) & (4) \\
\hline Harvest quality score & $74.40 * *$ & $100.4 * *$ & $85.23 *$ & 191.2 \\
\hline & $(35.49)$ & $(44.96)$ & $(47.68)$ & (128.4) \\
\hline High-value market participation (\%) & $1.841 * * *$ & $1.701^{* * *}$ & $1.936 * * *$ & \\
\hline & $(0.184)$ & $(0.239)$ & $(0.301)$ & \\
\hline Coffee lost as a result of pest-disease & & 0.469 & -0.0289 & -26.46 \\
\hline & & $(12.65)$ & $(13.84)$ & $(17.30)$ \\
\hline Coffee harvest in $\mathrm{kg}$ & & $-0.0296 * *$ & $-0.0306 * *$ & 0.0647 \\
\hline & & $(0.0127)$ & $(0.0130)$ & $(0.0576)$ \\
\hline Share of cherries sold fresh & & 0.400 & 0.288 & $1.578 * * *$ \\
\hline & & $(0.270)$ & $(0.289)$ & $(0.597)$ \\
\hline $\mathrm{Nr}$ of off-farm worker in hh & & $-18.67 * * *$ & $-18.70 * * *$ & 13.22 \\
\hline & & $(4.097)$ & $(4.261)$ & $(10.63)$ \\
\hline Observations & 1,522 & 848 & 761 & 87 \\
\hline R-squared & 0.072 & 0.115 & 0.122 & 0.107 \\
\hline
\end{tabular}

Notes: HV MP refers to high-value market participation. Pooled OLS estimations. Robust standard errors are reported in parentheses. $* * * \mathrm{p}<0.01, * * \mathrm{p}<0.05, * \mathrm{p}<0.1$

\subsection{Conclusion}

Agricultural technology adoption, which is positively associated with agricultural income, remains low in developing countries. Information failures are one impediment to adoption of welfare-improving technologies. Most developing countries allocates a considerable amount of government spending to agricultural extension services that rely on extension workers to deliver technical information to farmers. Yet, the evidence on the effectiveness of extension services is inconclusive. In order to design more effective extension modalities testing complementary approaches are gaining in importance. This study contributes to this agenda by testing the effectiveness of two different extention modalities and, in particular, exploring the role of the communicator in information delivery in extension. We evaluate the effects of information communicated by a plausibly more persuasive communicator in an extension meeting using a clustered randomised field experiment for identification. 
We randomly assigned a total of 1522 coffee growers in 88 farmer groups into three treatment groups and a control group in eastern Uganda. Keeping content identical, we varied the communicator in each treatment arm. Information was communicated by an extension worker alone (T1), by an extension worker and a peer farmer (T2), or by an extension worker and a high-status market actor (T3). Our hypothesis that a peer farmer is a more effective communicator of quality-related information whereas a high-status market actor is a more effective communicator of market-related information compared to the extension worker is based on persuasive effectiveness (credibility) of the communicators. In line with our hypotheses, we find larger effects on improved harvest practices if the extension worker is supported by a peer farmer. On the other hand, we find that farmers who receive information both from an extension worker and also a market actor do participate more in high-value markets. Results indicate that who communicates the information influences what technology is adopted. Additionally, harvest quality and participation in high-value markets lead to higher coffee revenues per kilogramme signaling the importance of high-value market participation for smallholder coffee farmers. We contribute mainly to the literature documenting information failures as a barrier to technology adoption and the role of different communicators in addressing such failures along with the literature on value chains and high-value market participation.

Key policy implications of this research are twofold. Firstly, identifying and addressing informational inefficiencies in a comprehensive way (about both product quality and high-value market participation) lead to better outcomes. Additionally, this strategy demonstrate a good example of how inclusive value chain development efforts could benefit smallholder farmers at the upstream segments of the value chains (De Janvry and Sadoulet, 2019). Secondly, we draw attention to the importance of the persuasive effectiveness of the communicator in delivering extension services. A given communicator's effectiveness may depend on the type of information and vary according to contextual factors. Hence, tailoring or augmenting the traditional extension services according to the context they operate in or complementing them with non-traditional communicators could increase adoption of better technologies eventually improving the welfare of small-scale producers in developing countries. Such communicators could be credible peer farmers or other value chain actors, such as the buyer of a product as in our case or agro-dealers as studied by Emerick and Sadoulet (2017).

There are two caveats, however. One is about the particularity of the practices pro- 
moted in this study. As Magruder (2018) points out, informational barriers may be different for familiar and unfamiliar practices. This study focuses on practices which farmers are familiar with and about which informational barriers might be easier to address. Similar to the work of Hanna et al. (2014) our intervention aims to help farmers optimise along some input dimensions they are not fully aware of. However, our conclusions, in particular, regarding the effectiveness of communicators should provide insights into any information provision intervention in any field. The second caveat is about the particularity of the extension workers in our study. The extension workers that led the extension meetings are employed by the largest exporter in the area and not by the government, but they operate in a similar way. In addition, these extension workers are usually from the study area. In their in-depth study on the agricultural extension system in Mali, Reid and Salmen (2000) draw attention to an overlooked aspect of extension systems: an understanding of the local context by the extension worker so that villagers are responsive to the communication made. They indicate that a lack of understanding of the local context by extension workers may hinder their effectiveness. Such mostly-unobserved characteristics may explain the mixed results in the literature. Consistently, the positive effects of overall extension we find can possibly be explained at least partly by effectiveness of the extension workers who understand the local context well. Further research may shed light on the extent to which the effectiveness of extension workers depends on their understanding of the context they operate in. Future research perhaps could provide evidence regarding which other extension approaches or modalities are effective in inducing adoption of welfare-improving practices and, more critically, regarding the mechanisms that channel the effects in order to inform policies and improve the welfare of smallholder farmers in developing countries.

\subsection{Additional tables}


Table 2.10: Treatment effects on harvest quality scores, high-value market participation, and revenues earned per kilogram

\begin{tabular}{|c|c|c|c|c|c|c|c|c|c|}
\hline & \multicolumn{3}{|c|}{$\begin{array}{c}\text { Harvest quality } \\
\text { score }(0-3)\end{array}$} & \multicolumn{3}{|c|}{$\begin{array}{l}\text { High-value market } \\
\text { participation (\%) }\end{array}$} & \multicolumn{3}{|c|}{$\begin{array}{c}\text { Revenues per kg } \\
\text { in UShs }\end{array}$} \\
\hline & $\begin{array}{l}\text { OLS } \\
(1)\end{array}$ & $\begin{array}{l}\text { OLS } \\
(2)\end{array}$ & $\begin{array}{l}\text { OLS } \\
(3)\end{array}$ & $\begin{array}{l}\text { DiD } \\
\text { (4) }\end{array}$ & $\begin{array}{l}\mathrm{DiD} \\
(5)\end{array}$ & $\begin{array}{l}\text { DiD } \\
(6)\end{array}$ & $\begin{array}{l}\text { DiD } \\
(7)\end{array}$ & $\begin{array}{l}\mathrm{DiD} \\
(8)\end{array}$ & $\begin{array}{l}\text { DiD } \\
\text { (9) }\end{array}$ \\
\hline Assigned to $\mathrm{T} 1$ & $\begin{array}{c}0.120 * \\
(0.0700)\end{array}$ & $\begin{array}{c}0.108^{*} \\
(0.0565)\end{array}$ & $\begin{array}{l}0.116 * * \\
(0.0568)\end{array}$ & $\begin{array}{l}-5.204 \\
(3.716)\end{array}$ & $\begin{array}{c}-2.601 \\
(4.526)\end{array}$ & $\begin{array}{l}-2.675 \\
(4.828)\end{array}$ & $\begin{array}{c}-2.234 \\
(17.30)\end{array}$ & $\begin{array}{c}8.753 \\
(26.40)\end{array}$ & $\begin{array}{c}10.76 \\
(24.75)\end{array}$ \\
\hline Assigned to $\mathrm{T} 2$ & $\begin{array}{l}0.144^{* *} \\
(0.0723)\end{array}$ & $\begin{array}{l}0.282^{* * * *} \\
(0.0635)\end{array}$ & $\begin{array}{l}0.340 * \cdots \\
(0.0607)\end{array}$ & $\begin{array}{l}-5.844 \\
(4.141)\end{array}$ & $\begin{array}{l}-8.200 \\
(5.242)\end{array}$ & $\begin{array}{l}-8.167 \\
(5.237)\end{array}$ & $\begin{array}{l}-14.33 \\
(15.20)\end{array}$ & $\begin{array}{c}8.610 \\
(30.68)\end{array}$ & $\begin{array}{c}-6.631 \\
(31.51)\end{array}$ \\
\hline Assigned to T3 & $\begin{array}{c}0.0998 \\
(0.0694)\end{array}$ & $\begin{array}{c}0.117^{*} \\
(0.0670)\end{array}$ & $\begin{array}{c}0.134 * * \\
(0.0611)\end{array}$ & $\begin{array}{c}-8.234 * * \\
(3.740)\end{array}$ & $\begin{array}{c}-9.888^{* * *} \\
(4.167)\end{array}$ & $\begin{array}{l}-7.848^{*} \\
(4.376)\end{array}$ & $\begin{array}{c}-18.15 \\
(16.51)\end{array}$ & $\begin{array}{c}-32.79 \\
(28.22)\end{array}$ & $\begin{array}{l}-31.08 \\
(26.72)\end{array}$ \\
\hline Post Treatment & & & & $\begin{array}{c}3.444 \\
(2.563)\end{array}$ & $\begin{array}{l}6.545^{*} \\
(3.463)\end{array}$ & $\begin{array}{l}6.415^{*} \\
(3.471)\end{array}$ & $\begin{array}{c}116.1 * * * \\
(19.81)\end{array}$ & $\begin{array}{c}131.1^{* * * *} \\
(28.40)\end{array}$ & $\begin{array}{c}132.3^{* * *} \\
(28.36)\end{array}$ \\
\hline Interaction ( $\mathrm{T} 1 *$ Post) & & & & $\begin{array}{c}2.541 \\
(3.452)\end{array}$ & $\begin{array}{l}-0.602 \\
(4.639)\end{array}$ & $\begin{array}{l}-0.336 \\
(4.744)\end{array}$ & $\begin{array}{l}-23.49 \\
(26.31)\end{array}$ & $\begin{array}{c}-37.13 \\
(34.09)\end{array}$ & $\begin{array}{c}-34.43 \\
(33.87)\end{array}$ \\
\hline Interaction ( $\mathrm{T} 2 *$ Post) & & & & $\begin{array}{c}1.417 \\
(4.322)\end{array}$ & $\begin{array}{c}5.559 \\
(5.454)\end{array}$ & $\begin{array}{c}5.314 \\
(5.402)\end{array}$ & $\begin{array}{c}0.696 \\
(27.31)\end{array}$ & $\begin{array}{c}0.726 \\
(37.18)\end{array}$ & $\begin{array}{c}5.210 \\
(37.89)\end{array}$ \\
\hline Interaction ( $\mathrm{T} 3 *$ Post) & & & & $\begin{array}{c}9.861^{* * *} \\
(3.585)\end{array}$ & $\begin{array}{l}11.21^{* * *} \\
(4.544)\end{array}$ & $\begin{array}{l}11.33^{* * *} \\
(4.622)\end{array}$ & $\begin{array}{l}14.80 \\
(31.63)\end{array}$ & $\begin{array}{c}25.29 \\
(37.26)\end{array}$ & $\begin{array}{c}26.25 \\
(37.56)\end{array}$ \\
\hline Constant & $\begin{array}{l}0.801 * * * \\
(0.0374)\end{array}$ & $\begin{array}{l}0.914 * * * \\
(0.0869)\end{array}$ & $\begin{array}{l}1.021 * * * \\
(0.262)\end{array}$ & $\begin{array}{c}82.05 * * * \\
(2.313)\end{array}$ & $\begin{array}{l}92.36 * * * \\
(5.494)\end{array}$ & $\begin{array}{c}102.0^{* * * *} \\
(6.661)\end{array}$ & $\begin{array}{c}1,181 * * * \\
(9.569)\end{array}$ & $\begin{array}{c}1,289 * * * \\
(36.96)\end{array}$ & $\begin{array}{c}1,364 * * * \\
(38.41)\end{array}$ \\
\hline $\begin{array}{l}\text { Strata FE } \\
\text { Observations }\end{array}$ & 1,522 & 1,522 & $\begin{array}{c}\text { Yes } \\
1,522\end{array}$ & 3,044 & 2,370 & $\begin{array}{c}\text { Yes } \\
2,370\end{array}$ & 3,044 & 2,370 & $\begin{array}{c}\text { Yes } \\
2,370\end{array}$ \\
\hline R-squared & 0.010 & 0.090 & 0.109 & 0.014 & 0.066 & 0.078 & 0.065 & 0.103 & 0.112 \\
\hline
\end{tabular}

Notes: Controls include the baseline value of the outcome variable, harvest in kilograms in the previous harvest season (2017), experience with coffee farming in years, if the coffee was attacked by pests or diseases before the harvest season (2018), extension meetings attended within the last 12 months of baseline survey date, household size, sex and education level of household head, total number of assets and livestock, distance to nearest tarmac road in kilometers, altitude region (lower, middle, and upper), and an indicator variable that takes the value 1 if the peer farmer treatment was not implemented and 0 otherwise. Specifications that include strata fixed-effects (FE) do not include the controls of education level of the household head, baseline harvest levels, and 3 altitude regions. Standard errors are clustered at the farmer group level and reported in parentheses. Standard errors are clustered at the farmer group level and reported in parentheses.**** $\mathrm{p}<0.01, * * \mathrm{p}<0.05$, $\mathrm{p}<0.1$ 
Table 2.11: Effects on harvest quality scores (full specification)

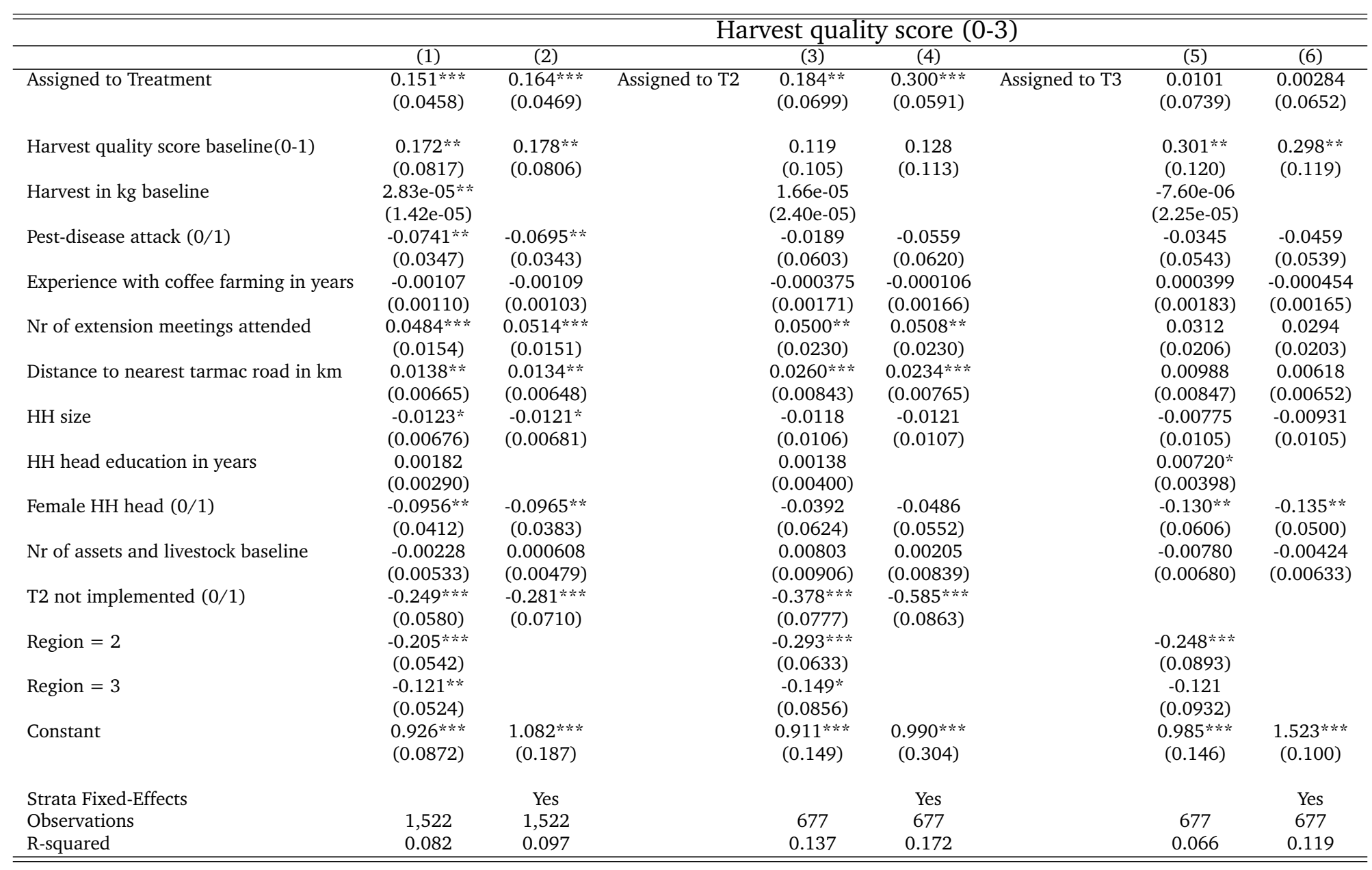

Notes: OLS Estimations. Standard errors are clustered at the farmer group level and reported in parentheses.*** $\mathrm{p}<0.01, * *$ $\mathrm{p}<0.05, * \mathrm{p}<0.1$ 
Table 2.12: Effects on high-value market participation (full specification)

\begin{tabular}{|c|c|c|c|c|c|c|c|c|}
\hline & \multicolumn{8}{|c|}{ High-value market participation (\%) } \\
\hline & (1) & (2) & & (3) & (4) & & (5) & (6) \\
\hline Assigned to Treatment & $\begin{array}{l}6.400^{*} \\
(3.471)\end{array}$ & $\begin{array}{l}6.260^{*} \\
(3.473)\end{array}$ & Assigned to $\mathrm{T} 2$ & $\begin{array}{l}-6.713 \\
(5.433)\end{array}$ & $\begin{array}{l}-7.329^{*} \\
(4.119)\end{array}$ & Assigned to T3 & $\begin{array}{l}-7.565^{*} \\
(4.383)\end{array}$ & $\begin{array}{l}-6.678^{*} \\
(3.945)\end{array}$ \\
\hline Post Treatment & $\begin{array}{l}-6.594 * \\
(3.644)\end{array}$ & $\begin{array}{l}-5.776 \\
(4.014)\end{array}$ & Post T2 & $\begin{array}{c}5.839 \\
(3.482)\end{array}$ & $\begin{array}{l}6.625^{*} \\
(3.508)\end{array}$ & Post T3 & $\begin{array}{c}5.179 \\
(3.486)\end{array}$ & $\begin{array}{c}5.000 \\
(3.352)\end{array}$ \\
\hline $\begin{array}{l}\text { Interaction } \\
\text { (Treatment*Post) }\end{array}$ & $\begin{array}{c}5.268 \\
(3.975)\end{array}$ & $\begin{array}{c}5.364 \\
(4.021)\end{array}$ & $\begin{array}{l}\text { Interaction } \\
\text { (T2*Post) }\end{array}$ & $\begin{array}{c}6.631 \\
(5.287)\end{array}$ & $\begin{array}{c}5.363 \\
(5.368)\end{array}$ & $\begin{array}{l}\text { Interaction } \\
\text { (T3*Post) }\end{array}$ & $\begin{array}{l}11.45^{* * *} \\
(4.689)\end{array}$ & $\begin{array}{l}11.49 * * \\
(4.716)\end{array}$ \\
\hline Harvest in kg baseline & $\begin{array}{c}0.000722 \\
(0.000723)\end{array}$ & & & $\begin{array}{l}0.000374 \\
(0.00126)\end{array}$ & & & $\begin{array}{l}-0.00998 \\
(0.0142)\end{array}$ & \\
\hline Coffee lost as a result of pest-disease & $\begin{array}{l}-1.378 * * \\
(0.624)\end{array}$ & $\begin{array}{c}-1.321 * * \\
(0.582)\end{array}$ & & $\begin{array}{l}-2.072^{* * *} \\
(0.889)\end{array}$ & $\begin{array}{l}-1.508^{*} \\
(0.827)\end{array}$ & & $\begin{array}{c}5.123 * * * \\
(1.408)\end{array}$ & $\begin{array}{l}-9.155 \\
(6.140)\end{array}$ \\
\hline Experience with coffee farming in years & $\begin{array}{c}-0.119^{*} \\
(0.0701)\end{array}$ & $\begin{array}{l}-0.139 * * \\
(0.0666)\end{array}$ & & $\begin{array}{c}-0.0998 \\
(0.0892)\end{array}$ & $\begin{array}{c}-0.128 \\
(0.0853)\end{array}$ & & $\begin{array}{l}-11.06^{*} \\
(5.852)\end{array}$ & $\begin{array}{l}0.0326 \\
(0.629)\end{array}$ \\
\hline $\mathrm{Nr}$ of extension meetings attended & $\begin{array}{c}0.929 \\
(0.581)\end{array}$ & $\begin{array}{l}1.000^{*} \\
(0.573)\end{array}$ & & $\begin{array}{l}-0.560 \\
(1.046)\end{array}$ & $\begin{array}{l}-0.0707 \\
(1.002)\end{array}$ & & $\begin{array}{c}0.376 \\
(0.711)\end{array}$ & $\begin{array}{l}-8.246^{*} \\
(4.725)\end{array}$ \\
\hline Share of cherries sold & $\begin{array}{l}-0.109 * * * * \\
(0.0233)\end{array}$ & $\begin{array}{l}-0.115^{* * * *} \\
(0.0260)\end{array}$ & & $\begin{array}{l}-0.154^{* * * *} \\
(0.0356)\end{array}$ & $\begin{array}{c}-0.180 * \cdots * \\
(0.0378)\end{array}$ & & $\begin{array}{l}-10.78^{* * *} \\
(4.259)\end{array}$ & $\begin{array}{c}-1.208 * \cdots * \\
(0.226)\end{array}$ \\
\hline Distance to nearest tarmac road in $\mathrm{km}$ & $\begin{array}{c}0.121 \\
(0.286)\end{array}$ & $\begin{array}{l}0.0447 \\
(0.267)\end{array}$ & & $\begin{array}{c}0.426 \\
(0.380)\end{array}$ & $\begin{array}{c}0.243 \\
(0.295)\end{array}$ & & $\begin{array}{c}-1.161^{* * * *} \\
(0.251)\end{array}$ & $\begin{array}{c}1.234 \\
(2.380)\end{array}$ \\
\hline Nr off-farm labour in hh & $\begin{array}{l}1.118^{* * *} \\
(0.451)\end{array}$ & $\begin{array}{l}1.124^{* * *} \\
(0.454)\end{array}$ & & $\begin{array}{c}0.752 \\
(0.688)\end{array}$ & $\begin{array}{c}0.640 \\
(0.654)\end{array}$ & & $\begin{array}{c}2.047 \\
(2.456)\end{array}$ & $\begin{array}{l}6.602 \ldots \\
(3.086)\end{array}$ \\
\hline HH head education in years & $\begin{array}{l}0.326^{* * *} \\
(0.144)\end{array}$ & & & $\begin{array}{c}0.291 \\
(0.234)\end{array}$ & & & $\begin{array}{l}4.961^{*} \\
(2.839)\end{array}$ & \\
\hline Female HH head $(0 / 1)$ & $\begin{array}{l}3.175 \\
(2.535)\end{array}$ & $\begin{array}{c}2.459 \\
(2.481)\end{array}$ & & $\begin{array}{c}-0.714 \\
(4.227)\end{array}$ & $\begin{array}{l}-1.328 \\
(4.141)\end{array}$ & & $\begin{array}{c}4.503 \\
(23.67)\end{array}$ & $\begin{array}{c}-4.074 \\
(22.60)\end{array}$ \\
\hline $\mathrm{Nr}$ of assets and livestock baseline & $\begin{array}{l}0.0872 \\
(0.268)\end{array}$ & $\begin{array}{c}0.174 \\
(0.264)\end{array}$ & & $\begin{array}{c}-0.262 \\
(0.417)\end{array}$ & $\begin{array}{c}-0.103 \\
(0.408)\end{array}$ & & $\begin{array}{c}-1.053 \\
(2.061)\end{array}$ & $\begin{array}{c}-0.242 \\
(2.058)\end{array}$ \\
\hline T2 not implemented $(0 / 1)$ & $\begin{array}{c}-5.861 \\
(6.884)\end{array}$ & $\begin{array}{l}-5.829 \\
(5.880)\end{array}$ & & $\begin{array}{l}-2.985 \\
(7.662)\end{array}$ & $\begin{array}{l}1.071 \\
(7.159)\end{array}$ & & & \\
\hline Region $=2$ & $\begin{array}{c}-7.864 * * * * \\
(2.608)\end{array}$ & & & $\begin{array}{l}-11.06^{* * *} \\
(4.783)\end{array}$ & & & $\begin{array}{l}-58.76^{* *} \\
(25.30)\end{array}$ & \\
\hline Region $=3$ & $\begin{array}{c}-11.00 * * * * \\
(2.546)\end{array}$ & & & $\begin{array}{c}-16.42^{* * *} \\
(4.727)\end{array}$ & & & $\begin{array}{c}-83.04 * * * \\
(11.77)\end{array}$ & \\
\hline Constant & $\begin{array}{l}92.41 * * * \\
(5.475)\end{array}$ & $\begin{array}{c}101.2 * * * \\
(6.712)\end{array}$ & & $\begin{array}{c}101.4^{* * * *} \\
(6.342)\end{array}$ & $\begin{array}{c}109.0 * * * \\
(5.811)\end{array}$ & & $\begin{array}{c}1,290 * * * \\
(47.71)\end{array}$ & $\begin{array}{c}1,396 * * * \\
(40.54)\end{array}$ \\
\hline Strata Fixed-Effects & & Yes & & & Yes & & & Yes \\
\hline Observations & 2,370 & 2,370 & & 1,069 & 1,069 & & 1,068 & 1,068 \\
\hline R-squared & 0.063 & 0.075 & & 0.086 & 0.131 & & 0.123 & 0.125 \\
\hline
\end{tabular}

Notes: DiD Estimations. Standard errors are clustered at the farmer group level and reported in parentheses. $* * * \mathrm{p}<0.01, * *$ $\mathrm{p}<0.05, * \mathrm{p}<0.1$ 
Table 2.13: Effects on revenues per kilogram (full specifiation)

\begin{tabular}{|c|c|c|c|c|c|c|c|c|}
\hline & \multicolumn{8}{|c|}{ Revenues earned per kg in UShs } \\
\hline & $(1)$ & $(2)$ & & (3) & $(4)$ & & (5) & (6) \\
\hline Assigned to Treatment & $\begin{array}{c}-8.470 \\
(19.28)\end{array}$ & $\begin{array}{c}-10.02 \\
(18.25)\end{array}$ & Assigned to $\mathrm{T} 2$ & $\begin{array}{l}38.99^{*} \\
(20.22)\end{array}$ & $\begin{array}{l}34.23^{*} \\
(18.15)\end{array}$ & Assigned to $\mathrm{T} 3$ & $\begin{array}{c}26.16 \\
(21.22)\end{array}$ & $\begin{array}{c}30.98 \\
(21.46)\end{array}$ \\
\hline Revenue per kg baseline & $\begin{array}{c}-0.0266 \\
(0.0322)\end{array}$ & $\begin{array}{l}-0.0338 \\
(0.0313)\end{array}$ & & $\begin{array}{c}-0.0194 \\
(0.0634)\end{array}$ & $\begin{array}{l}-0.0293 \\
(0.0613)\end{array}$ & & $\begin{array}{l}-0.00285 \\
(0.0665)\end{array}$ & $\begin{array}{c}0.0120 \\
(0.0646)\end{array}$ \\
\hline Harvest in kg baseline & $\begin{array}{c}0.0158 * \\
(0.00812)\end{array}$ & & & $\begin{array}{l}0.00848 \\
(0.0133)\end{array}$ & & & $\begin{array}{l}-0.00489 \\
(0.0118)\end{array}$ & \\
\hline Pest-disease attack $(0 / 1)$ & $\begin{array}{c}-3.077 \\
(15.22)\end{array}$ & $\begin{array}{c}-1.634 \\
(15.64)\end{array}$ & & $\begin{array}{c}18.11 \\
(23.45)\end{array}$ & $\begin{array}{c}15.14 \\
(24.30)\end{array}$ & & $\begin{array}{c}17.91 \\
(22.62)\end{array}$ & $\begin{array}{c}15.80 \\
(23.59)\end{array}$ \\
\hline Experience with coffee farming in years & $\begin{array}{c}0.358 \\
(0.619)\end{array}$ & $\begin{array}{l}0.0490 \\
(0.565)\end{array}$ & & $\begin{array}{c}-0.482 \\
(1.019)\end{array}$ & $\begin{array}{l}-0.672 \\
(0.953)\end{array}$ & & $\begin{array}{c}0.512 \\
(0.909)\end{array}$ & $\begin{array}{l}-0.203 \\
(0.809)\end{array}$ \\
\hline $\mathrm{Nr}$ of extension meetings attended & $\begin{array}{c}-5.495 \\
(6.524)\end{array}$ & $\begin{array}{c}-3.518 \\
(5.864)\end{array}$ & & $\begin{array}{c}-2.237 \\
(6.540)\end{array}$ & $\begin{array}{c}1.015 \\
(6.792)\end{array}$ & & $\begin{array}{c}-15.39 * * * * \\
(5.551)\end{array}$ & $\begin{array}{c}-13.81 * * \\
(6.132)\end{array}$ \\
\hline Distance to nearest tarmac road in $\mathrm{km}$ & $\begin{array}{c}-0.136 \\
(1.851)\end{array}$ & $\begin{array}{c}-0.470 \\
(2.086)\end{array}$ & & $\begin{array}{l}-3.479^{*} \\
(1.783)\end{array}$ & $\begin{array}{c}-3.698 * * \\
(1.823)\end{array}$ & & $\begin{array}{c}2.117 \\
(3.369)\end{array}$ & $\begin{array}{c}2.608 \\
(3.571)\end{array}$ \\
\hline HH size & $\begin{array}{c}4.491 \\
(2.948)\end{array}$ & $\begin{array}{l}4.639^{*} \\
(2.782)\end{array}$ & & $\begin{array}{c}1.597 \\
(4.009)\end{array}$ & $\begin{array}{l}0.0920 \\
(3.972)\end{array}$ & & $\begin{array}{l}6.643^{*} \\
(3.909)\end{array}$ & $\begin{array}{c}6.258 \\
(3.850)\end{array}$ \\
\hline $\mathrm{HH}$ head education in years & $\begin{array}{l}3.548 * * \\
(1.559)\end{array}$ & & & $\begin{array}{c}2.330 \\
(1.837)\end{array}$ & & & $\begin{array}{c}6.962^{* * * *} \\
(2.194)\end{array}$ & \\
\hline Female HH head $(0 / 1)$ & $\begin{array}{c}-0.858 \\
(17.87)\end{array}$ & $\begin{array}{c}-6.977 \\
(17.41)\end{array}$ & & $\begin{array}{c}28.16 \\
(28.52)\end{array}$ & $\begin{array}{c}24.07 \\
(28.18)\end{array}$ & & $\begin{array}{c}33.16 \\
(30.25)\end{array}$ & $\begin{array}{c}19.76 \\
(29.32)\end{array}$ \\
\hline $\mathrm{Nr}$ of assets and livestock baseline & $\begin{array}{c}1.004 \\
(2.750)\end{array}$ & $\begin{array}{c}2.326 \\
(2.520)\end{array}$ & & $\begin{array}{c}-1.022 \\
(3.774)\end{array}$ & $\begin{array}{c}0.289 \\
(3.641)\end{array}$ & & $\begin{array}{c}1.631 \\
(3.587)\end{array}$ & $\begin{array}{c}2.155 \\
(3.455)\end{array}$ \\
\hline T2 not implemented $(0 / 1)$ & $\begin{array}{c}-36.91 * * \\
(15.39)\end{array}$ & $\begin{array}{c}-20.88 \\
(15.94)\end{array}$ & & $\begin{array}{c}-60.61 * * * * \\
(20.93)\end{array}$ & $\begin{array}{l}-35.73 \\
(24.80)\end{array}$ & & & \\
\hline Region $=2$ & $\begin{array}{c}-80.26 * * * * \\
(23.70)\end{array}$ & & & $\begin{array}{c}-103.0 * * * * \\
(21.29)\end{array}$ & & & $\begin{array}{c}-104.2^{* * * *} \\
(31.27)\end{array}$ & \\
\hline Region $=3$ & $\begin{array}{c}-67.55^{* * * *} \\
(18.14)\end{array}$ & & & $\begin{array}{c}-54.54 * * \\
(23.58)\end{array}$ & & & $\begin{array}{c}-93.30 * * * * \\
(24.70)\end{array}$ & \\
\hline Constant & $\begin{array}{c}1,290 * * * \\
(46.93)\end{array}$ & $\begin{array}{c}1,346^{* * * *} \\
(46.30)\end{array}$ & & $\begin{array}{c}1,316 * * * \\
(81.75)\end{array}$ & $\begin{array}{c}1,363^{* * * *} \\
(81.46)\end{array}$ & & $\begin{array}{c}1,200 * * * \\
(82.89)\end{array}$ & $\begin{array}{c}1,267 * * * * \\
(87.14)\end{array}$ \\
\hline Strata Fixed-Effects & & Yes & & & Yes & & & Yes \\
\hline Observations & 1,522 & 1,522 & & 677 & 677 & & 677 & 677 \\
\hline R-squared & 0.037 & 0.049 & & 0.045 & 0.061 & & 0.053 & 0.053 \\
\hline
\end{tabular}

Notes: OLS Estimations. Standard errors are clustered at the farmer group level and reported in parentheses. $* * * \mathrm{p}<0.01$,

$* * \mathrm{p}<0.05, * \mathrm{p}<0.1$ 


\section{Chapter 3}

\section{Paying more to make less: value degrading in the cof- fee value chain in eastern Uganda}

Coffee growing households regularly undertake home-processing of coffee cherries harvested and sell parchment coffee: an activity that is commonly regarded as value-adding. We show that parchment production is, in fact, a value degrading activity that generates a considerable potential profit loss for households selling large amounts of parchment due partly to it being associated with quality uncertainty and asymmetric information that generate a "market for lemons". Using primary data collected from 1610 coffee growing households and employing an instrumental variable approach, we show that greater levels of participation in parchment markets are associated with lower coffee income. Further analysis indicates that growers with a lack of understanding of the effective costs of parchment production are more likely to engage with parchment production. Growers with higher levels of knowledge regarding coffee quality and cognitive skills produce relatively less parchment coffee using mainly lower quality coffee cherries. Our results indicate that efforts for value upgrading through processing of fresh produce in agri-food markets can also generate a value reduction. Activities aiming at moving growers up the value chain should thus be integrated with relevant characteristics of the supply chain, such as quality-assurance.

Keywords: value chains; upgrading; quality uncertainty; asymmetric information; coffee; Uganda

JEL Codes: D8, O13, Q13

This chapter is a joint work with Daniel Gregg and Meike Wollni. I designed the research, collected and analysed the data, and wrote the manuscript. Daniel Gregg and Meike Wollni provided feedback at various stages of the research and revised the manuscript. 


\subsection{Introduction}

While considerable progress has been made over the last 30 years in poverty reduction, about one-tenth of the people in the world still live in extreme poverty (World Bank, 2020). A large majority of the rural poor derive a significant proportion of their livelihood from farming with growth in the agricultural sector found to be four times more effective in reducing poverty than growth in other sectors in poor countries (World Bank, 2007). A market-based value chain approach to agricultural growth and development (i.e. value chain development) has been emphasised by the World Development Report 2008 and embraced as one of the pro-poor growth and development strategies in the past decade (World Bank, 2007; FAO, 2008; UNIDO, 2011; Stoian et al., 2012).

Value chain development strategies focus on "upgrading" of specific crops through actions that affect one or more levels of the supply chain but have welfare improving effects focused on upstream segments of the supply chain, such as farmers and farm labourers (Mitchell and Coles, 2011; Webber and Labaste, 2009). ${ }^{1}$ One key focus market is coffee which is produced predominantly by smallholder producers in developing countries. Notwithstanding some studies showing positive impacts of coffee value chain upgrading (Ruben and Fort, 2012; Chiputwa et al., 2015; Dragusanu and Nunn, 2018), in several cases efforts at product upgrading have failed to generate clear benefits to primary producers in the coffee supply chains (De Janvry et al., 2015; Vicol et al., 2018; Minten et al., 2018). Low levels of value transmission to large numbers of smallholder coffee farmers means that many of these farming households remain unable to access improved livelihoods through upgrading in the coffee value chain. In this study we focus on a particular type of upgrading, functional upgrading, defined as producers moving into more sophisticated products through processing raw produce into a more complex product.

Value chain upgrading is based on the rationale that value-added and processed products attract higher prices than raw ones, allowing producers to capture more rent within the value chain. Yet value capture based on upgrading relies largely on one of two main assumptions: (1) that value-addition and processing activities monotonically increase the value of the product in the supply chain, or; (2) that

\footnotetext{
${ }^{1}$ Value chain upgrading is defined, broadly, as producers or firms moving to higher value activities to increase the benefits, such as profits, value-added, and capabilities, from production (Gereffi, 2005). Product upgrading is defined as producers moving to higher-value products (e.g. through quality-enhancing or Fairtrade certification) whereas functional upgrading is producers taking on new actions, such as processing, and producing more complex products (Humphrey and Schmitz, 2002).
} 
buyers can easily ascertain the value-added (e.g. quality) of the product.

The first assumption implies that there is a progressive movement from an unprocessed, low-value product to a processed, higher-value product and that producers who upgrade capture greater value. This assumption is challenged by, for instance, Ponte and Ewert (2009) who argue that upgrading does not necessarily imply higher values retained and that downgrading may be a more profitable strategy for smallholder wine producers in South Africa. We argue that it may also not be the case for coffee. Harvesting and processing (fresh coffee cherries into parchment) activities are highly important factors in determining the quality of the final product. Thus, poorly undertaken harvesting and processing activities can in fact generate a low-quality coffee product out of a potential for a highquality product. Incapacity to meet the quality standards required by high-value markets can in turn push producers down to the lower-quality supply chain.

Regarding the assumption that buyers can ascertain the value-added of the product, we argue that markets for processed product "parchment" are subject to quality uncertainty and information asymmetry which generate a market for lemons in the vein of Akerlof (1970). In the case that this assumption does not hold, it is possible that processing of coffee cherries does not generate higher values for households engaging in those activities relative to the sale of basic produce.

Our study is focused on the Mount Elgon region of eastern Uganda, the largest producer of Arabica coffee in Uganda. There are about 500,000 coffee-growing households in the region of whom a large majority are smallholders (UCDA, 2020). Coffee growers in the Mount Elgon region either market their coffee cherries picked fresh from their garden or, alternatively, home-process the coffee cherries harvested and sell their coffee in a dried form called parchment. Parchment production involves a range of processing activities including pulping of coffee (removing the skin), fermentation (removing the fruit), and drying (Figure 3.3). These processes tend to transform 5 kiprogramme of harvested fresh coffee cherries into 1 kilogramme of parchment (Mujawamariya et al., 2013). Thus, for profits from coffee to be increased for households undertaking parchment production, the price of parchment needs to be at least 5 times higher compared to coffee cherries (net of costs). This choice between parchment production versus the sale of freshly picked coffee cherries is the key area of analysis. In particular, the production of parchment remains high in the area despite prices for parchment being only 4-4.5 times the price of fresh cherries. We seek to examine whether parchment production involves a net profit loss indicating that parchment markets may constitute a 
market for lemons due to quality uncertainty and asymmetric information in this market. There is no quality uncertainty in the fresh cherry market.

In this paper we test if upgrading, producing a partly-processed coffee product, is associated with lower coffee income than producing a non-processed coffee product for smallholder coffee producers i.e. whether value chain upgrading activities are in fact "value degrading". Our key research question is thus the following: to what extent is upgrading through processing more profitable than selling nonprocessed coffee cherries for smallholder coffee producers? To answer this question, we analyse primary data collected from 1610 Arabica coffee growing households in eastern Uganda. In particular, we model coffee revenues and profits as a function of upgrading through processing fresh cherries into parchment. To deal with potential endogeneity of coffee processing decisions and profits, we employ an instrumental variable (IV) approach. The results of both OLS and IV estimations indicate that home-processed parchment coffee generates considerably lower coffee revenues and profits. The results are both substantive and significant with processing of coffee generating an average of 10-20 percent decline in revenues without accounting for the processing costs. The potential loss associated with parchment production is even larger in overall coffee profits than revenues. Given the lower farm income associated with parchment production, we also consider the factors associated with participation in the parchment market in Uganda. In particular we focus on rationalization of participation through information constraints, cognitive constraints, and physical constraints (e.g. market access).

This study contributes to the value chain development literature in a key way by providing causal evidence on the household-level welfare effects of upgrading in the coffee value chain. A majority of studies in this literature focuses on product upgrading through value-addition and predominantly by certification (e.g. Fairtrade and Organic). While a considerable number of studies document positive effects of product upgrading (Wollni and Zeller, 2007; Barham and Weber, 2012; Ruben and Fort, 2012; Dragusanu et al., 2014; Chiputwa et al., 2015; Dragusanu and Nunn, 2018; Sellare et al., 2020), several other studies find no or little measurable effect on household welfare (Valkila and Nygren, 2010; Beuchelt and Zeller, 2011; Jena et al., 2012; Elder et al., 2012; Cramer et al., 2014; De Janvry et al., 2015; Minten et al., 2018). Our study is differentiated from these quantitative coffee value chain studies by focusing on upgrading through moving from an unprocessed fresh produce to a processed and more sophisticated product (i.e. functional upgrading). 
Gibbon and Ponte (2005) argue that functional upgrading is expensive and risky and the rewards are not necessarily clear particularly for producers. Ponte and Ewert (2009) also argue that smallholder farmers are better off downgrading in the value chain for South African wine when, for instance, producers face high standards making sustainable participation at a particular level unviable. In other cases, functional downgrading reduces the vulnerability of smallholder producers as selling a basic product implies lower risk, albeit also lower return (Mitchell and Coles, 2011). This is not the case for coffee, however, as prices of the unprocessed, fresh produce are more stable than the processed product. Vicol et al. (2018) is one recent exception that studies upgrading through processing in the coffee sector in Indonesia. They also argue against profitability of upgrading through processing fresh coffee produce because smallholders capture little value due to an incapacity to produce higher quality coffee products. Despite their useful insights into profitability of functional upgrading, these studies are all qualitative and thus do not quantify the effects of upgrading at the household level. This paper provides first causal evidence on the household-level profitability of upgrading through processing in the coffee value chain dealing with endogeneity of processing decisions to profits. Additionally, we contribute to the literature by documenting the role of several factors associated with participation in processed coffee markets in eastern Uganda. This study thus relates to several strands of the literature, such as the literature that identifies information as a barrier to adoption of welfare-improving practices (Foster and Rosenzweig, 1995; Maertens and Barrett, 2013; Hanna et al., 2014; Kondylis et al., 2017) the literature that associates cognitive ability with better socio-economic outcomes (Murnane et al., 2000; Heckman et al., 2006; Almlund et al., 2011; Gertler et al., 2014) and the literature that studies the role of transaction costs in agricultural marketing by smallholder farmers (Key et al., 2000; Fafchamps and Hill, 2005; Ouma et al., 2010). Considering the role of quality uncertainty and asymmetric information, which appear to generate a market for lemons in upgrading decisions in the coffee value chain, we expand the adverse selection literature for a major cash crop produced by smallholder agrarian households in developing countries.

This study is organised as follows: the next section describes the coffee markets and context in which coffee farmer households operate. Section 3 focuses on empirical strategy. Section 4 presents our data and sample characteristics. Section 5 presents findings. Last section concludes. 


\subsection{Context: Fresh Cherry and Parchment Markets}

Coffee cherries picked fresh from the garden are either marketed on the day of harvest, due to high perishability of fresh produce, or are processed into parchment. Sale of fresh cherries requires either engagement of a local trader or transport to the local buying centres of a large processor/exporter in the area. ${ }^{2}$ In most cases, before being accepted by agents at the buying centres cherries are assessed for quality using a simple and rapid qualitative assessment of ripeness and the presence of damage from pests and diseases and these quality assessments are relatively easy to pass in most cases. As a result, there is substantial homogeneity in prices and qualities in the fresh cherry market across the Mount Elgon region with buyers usually applying a standard price for a certain level of quality of cherries. Although it is possible to price-differentiate according to quality this is rarely done in the Mount Elgon region. Whilst the quality threshold is relatively easy to meet, there are substantial numbers of growers who do not pass first-round assessments and must engage in sorting of their cherries at the buying stations in order to pass a second-round assessment. Sorting requires hiring labour (sorters) and is associated with value losses because cherries that are sorted out, if in small quantities, are discarded.

Alternatively, growers can choose to process cherries into parchment. Parchment markets are differentiated from fresh cherry markets in two ways: (1) they are substantially easier to transport (being approximately 5 times less weight and substantially lower in volume), and; (2) quality of parchment is much more difficult to assess compared to fresh cherries because complex physical and chemical transformations occur during processing of coffee cherries which are not visible to the naked eye (Poltronieri and Rossi, 2016). Indeed, while coffee cherries are easily quality-differentiated on the basis of colour and the presence of insect damage to the cherry, parchment is largely of a uniform colour when dry (even for low quality parchment) and damage is difficult to discern except for gross quality issues (e.g. stones and major insect damage). As a result, parchment that will only yield lowquality coffee and parchment that can yield high-quality coffee can trade at similar or equal prices. The costs of producing parchment can be substantial involving the requirement to pulp cherries using a pulping machine, a fermentation process of 24-36 hours, the need for drying equipment, and the substantial time that it takes to dry parchment. Given that price discrimination according to quality is not easy,

\footnotetext{
${ }^{2}$ Market access is typically not a problem for a majority of growers in the study area since there are many buying centres across the district. This buyer has a processing station where coffee cherries are processed under strict monitoring of quality parameters. Coffee beans are then exported as high-value and/or certified coffee.
} 
there are cost-based incentives to not invest in the quality of parchment where possible. The lack of effective and efficient quality assessment methods for parchment purchases in rural areas means that growers are unlikely to put effort into producing high-quality parchment. This is effectively a description of Akerlof's "market for lemons" (Akerlof, 1970).

Quality uncertainty and asymmetric information between the buyer and the seller generates a market for lemons in which both the quality and prices of the products traded in the market tend to go down. In particular, given that the parchment quality cannot easily be ascertained, parchment buyers usually offer a price that is somewhere between the prices of low-quality and higher quality parchment. Producers of poor-quality parchment will be more likely to sell at the average price offered whereas producers who have higher quality parchment will be less likely to participate in trades in the parchment market. When enough sellers of high-quality products leave the market, the average prices that buyers pay will decrease along with the average quality on the market. Given that the parchment market has the elements of a market for lemons, does engagement with parchment markets generate lower profits? And what factors are associated with greater engagement with parchment production? We consider the role of a range of possible economic drivers; market requirements, informational inefficiencies, and behavioural aspects including cognitive ability, which we rationalise in the following.

Quality criteria in the fresh cherries market may induce producers to produce substantial levels of parchment production, if they result in large amounts of coffee cherries failing to meet quality thresholds. Low-quality cherries may be sold to traders (who can more effectively aggregate different lots to meet quality thresholds) or self-processed into parchment. Growers with lower investment in agronomy or from lower-quality regions (i.e. lower altitudes that tend to be drier and hotter) or growers who hire coffee pickers who are not incentivised to harvest high quality coffee may be more likely to produce parchment coffee due to the presence of quality thresholds in the coffee cherry market. Similarly, growers who have lower capacity in determining cherry quality may have a lower passing rate for harvested cherries resulting in larger levels of parchment sales. This may arise, for instance, from a lack of knowledge on improved harvest practices and coffee quality. Informational barriers, a commonly documented barrier to adoption of welfare-improving agricultural practices (Foster and Rosenzweig, 1995; Conley and Udry, 2010) may thus play a role in the extent to which producers engage with parchment production. Hanna et al. (2014) and Islam (2014) document that 
farmers fail to optimise along the input dimensions they do not notice even if they are familiar with the practice. In the case of coffee, informational inefficiencies regarding the effective cost of inputs required to produce parchment and effective price differentials between the fresh cherries and parchment coffee may be associated with higher levels of parchment. The latter may arise because payments for parchment will be much larger for the same weight (due to the loss of weight in transformation to parchment). This may become a focus of households through a preference for large lump-sum payments if saving is difficult. Collins et al. (2009) document demand for small irregular flows of income to be aggregated into lumpsums for investment by the poor in developing countries of whom a large majority still lack access to formal banking services of any kind (Banerjee and Duflo, 2007; Dupas and Robinson, 2013). Cognitive abilities may play a role in parchment production decisions through a variety of mechanisms such as easing information constraints about effective cost and price differentials in coffee market.

Lastly, physical or cash constraints may also play a role in the extent to which coffee farmers sell parchment coffee. Physical barriers may include the distance to coffee buying centres (market). Roads in the area can be hazardous after rain potentially increasing transport costs. Fafchamps and Hill (2005) show that farmers do factor in physical and cash constraints in their marketing decisions and are more likely to transport their product to the market (versus selling at farm gate) when the market is closer and the quantity sold is large.

\subsection{Identification and Estimation Strategy}

In this section we first present our identification and estimation strategy to establish whether parchment production reduces revenues and profits per kilogramme of coffee harvested. In the second subsection we present the estimation strategy for an analysis of factors that predict engagement with parchment production.

\subsubsection{Estimating the effect of parchment production on rev- enues and profits}

We set out to establish the role of parchment production in affecting total household coffee revenues and profits. Under the lemon-market hypothesis associated with "value degrading" we outlined earlier, those households producing parchment (or more parchment) would make lower profits than those producing only coffee cherries (or producing a lower share of parchment in total coffee output). Standard regression approaches are, however, likely to be confounded by endogeneity 
of the parchment production decision.

Parchment production and coffee income are endogenous since coffee growers choose the extent to which they engage with parchment production partly according to coffee prices and the production costs they incur. Causal estimation of the effect of upgrading through processing on revenues and profits depends on isolating plausibly exogenous variation in upgrading through processing decisions. A majority of studies in the literature that assess the effect of product upgrading using observational data deal with the endogeneity issue by matching and balancing methods (Ruben and Fort, 2012; Chiputwa et al., 2015; Meemken and Qaim, 2018). Whilst these methods account for observed heterogeneity, they fail to adequately control for unobserved characteristics between the farmers who produce parchment and who do not. Our identification strategy relies on farmers' access to a pulping machine (used to remove the skin of cherries) and its differential effects on parchment production levels. In particular, we employ an Instrumental Variable (IV) approach to assess the effect of upgrading through processing on coffee profits.

A valid instrument for application of the IV method must be: (1) correlated with the endogenous regressor, in this case parchment production, and; (2) uncorrelated with the error term (Angrist and Pischke, 2009; Wooldridge, 2010). Pulping machine access is one such variable that is likely to meet these conditions. In particular, since pulping cherries is the first step of processing cherries into parchment, pulper access is highly correlated with parchment production (the endogenous regressor in our revenue and profit functions). Specifically, pulper access is defined as the number of farmers who own a pulper in one's farmer group. Coffee farmer groups are mostly formed at the village level except for very small villages (in which case a few small villages are grouped into one). The exclusion restriction requires that the instrument should be independent of potential outcomes (conditional on covariates) and uncorrelated with the dependent variable. In other words, the number of households who own a pulper in one's village should have no correlation to coffee income other than through its correlation with parchment production decision. This assumption is not directly testable, yet we argue that access to a pulper, exclusively used for coffee processing, has no effect on coffee revenues. Farmers are price-takers and the prices are set according to the world market and announced publicly by the largest buyer in the area. One might nonetheless argue that having a pulper in close proximity might be correlated with profits through processing costs. We have anecdotal evidence that coffee farmers 
rent pulpers at a fixed cost per kilogramme across the whole district. Proximity to a pulper would thus not directly affect the monetary cost of processing which is what is included in profit calculations. To rule out some of the endogeneity concerns with the instrument (e.g., that being in a group with more pulpers is correlated with profits via network mechanisms or other ways) we also control for distance to the nearest coffee buying centre (nearest market).

In the light of these arguments, we conclude that the instrument, the number of pulpers in one's group, satisfies the conditions for a valid instrument. We thus employ the two-stage least squares (2SLS) method and estimate the following:

$$
\begin{gathered}
Y_{i}=\alpha_{0}+\alpha_{1} \hat{P}_{l}+X_{i}^{\prime} \delta+\varepsilon_{i} \\
P_{i}=\beta_{0}+\beta_{1} \text { pulper }_{i}+X_{i}^{\prime} \delta+v_{i}
\end{gathered}
$$

where $Y_{i}$ measures our outcomes, revenues or profits per kilogramme of household $i . P_{i}$ represents an indicator variable that takes the value 1 if the household $i$ produces parchment and 0 otherwise. Alternatively, it represents the share of processed cherries into parchment. pulper $_{i}$ is the instrument representing the number of households who own a pulper in household i's group. $X$ is a vector of covariates which includes household and farm characteristics and, depending on the specification, region fixed-effects ( 3 altitude regions in the district which may have distinct characteristics). $\varepsilon_{i}$ and $v_{i}$ are the respective error terms. Under the identifying assumptions, $\alpha_{1}$ is the causal effect of parchment production on revenues and profits. We cluster standard errors at the village level.

IV estimates may differ from the OLS estimates because the 2SLS estimator gives us the local average treatment effect, i.e. the effect of parchment production for the farmers whose decisions are affected by the instrument, pulper access, and this sub-set of households is not necessarily representative of the entire sample.

\subsubsection{Estimating drivers of parchment production}

To explore the drivers of parchment production we use a double-hurdle model approach. In the first hurdle we model the decision to whether or not produce parchment (a binary choice model). In the second hurdle we model the extent of parchment production as the share (percentage) of harvested cherries taken up by parchment production for those with positive parchment production (a continu- 
ous choice model).

A substantial portion (59 percent) of the growers in our sample do not produce any parchment and the share of cherries processed into parchment takes the value of zero for them. In such situations where there is a lower and/or upper corner solution, the standard Tobit model (Tobin, 1958) may be used. However, the Tobit model assumes that the coefficients/models for the uncensored and censored portions of the likelihood function are similar in function, direction and magnitude (Wooldridge, 2010; Greene, 2009). Applying it to our context, the Tobit model assumes that the choice of parchment production and the share of cherries processed into parchment are determined through the same underlying process.

Generalizing the assumption of the original Tobit, that participation decisions (to produce or not to produce) could be modelled as the same process as the observed outcomes conditional on participation, Cragg (1971) proposed a doublehurdle model. The Cragg double-hurdle model allows the two decisions (producing parchment and the extent of parchment production) to be determined by separate processes through the incorporation of a probit model in the first stage and a truncated normal model in the second stage.

Cragg's model is commonly used to analyse determinants of market participation (Rao and Qaim, 2013; Fischer and Qaim, 2014) because the theory suggests fixed costs will have countervailing effects on the likelihood of a non-zero outcome and the expected value of a given non-zero outcome (Burke, 2019). Bellemare and Barrett (2006) show that marketing decisions are often made sequentially and not necessarily simultaneously by farmers in Kenya and Ethiopia. We also prefer Cragg's double-hurdle model over Tobit model because the assumption that the processes are determined by the same set of explanatory variables and in the same direction is unlikely to hold in our case.

A large portion (30 percent) of the households that engage with parchment production produce solely parchment meaning that the outcome variable in the second stage regression takes the value of 100 . To check robustness of our estimates to this factor in the distribution of our outcome variable, we also estimate the second stage truncated not only at the lower bound (no parchment) but also at the upper bound (100 percent parchment). The distribution of the outcome variable appears approximately normal given this upper-truncation (Figure 3.1). Cragg's model can formally be specified as follows: 


$$
\begin{aligned}
y_{i, 1}^{*}=w_{i}^{\prime} \alpha+e_{i} & \text { Parchment production decision } \\
y_{i, 1}=1 & \text { if } y_{i, 1}^{*}>0 \\
y_{i, 1}=0 & \text { otherwise } \\
& \\
y_{i, 2}^{*}=x_{i}^{\prime} \beta+u_{i} & \text { Extent of parchment production } \\
y_{i, 2}=y_{i, 2}^{*} & \text { if } y_{i, 2}^{*}>0 \text { and } y_{i, 1}^{*}=1 \\
y_{i, 2}=0 & \text { otherwise }
\end{aligned}
$$

where $y_{i, 1}^{*}$ is the latent (unobserved) variable which indicates the grower's underlying decision to produce parchment and $w_{i}$ is the observed decision to produce parchment. $w_{i}$ takes a value one if household $i$ produces parchment and zero otherwise. $y_{i, 2}^{*}$ is the latent (unobserved) variable indicating the extent of cherries used to sell parchment and takes a value zero for farmers who do not produce any parchment. $\alpha$ and $\beta$ are the coefficients to be estimated. $e_{i}$ and $u_{i}$ are the respective error terms following IID distributions (Cragg, 1971; Wooldridge, 2010). Cragg's model involves the alternative of lognormal truncated model in which the latent variable has a lognormal distribution. As with the truncated normal model, estimation of the parameters can proceed in two steps.

Figure 3.1: Distribution of share of cherries taken up by parchment (\%)

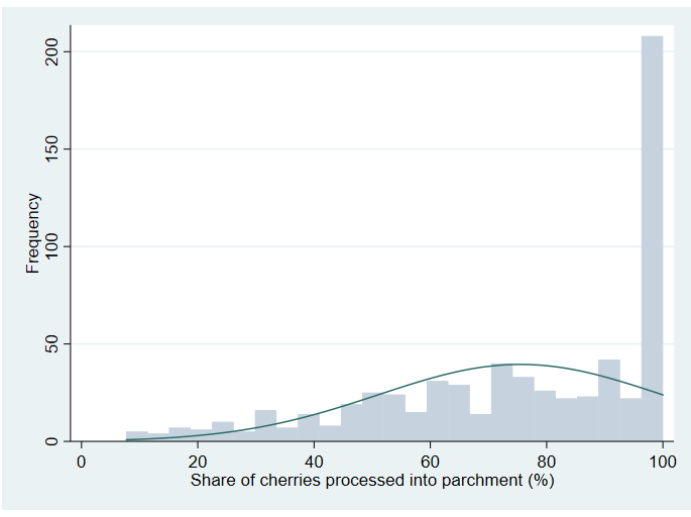

(a) Truncated at lower bound

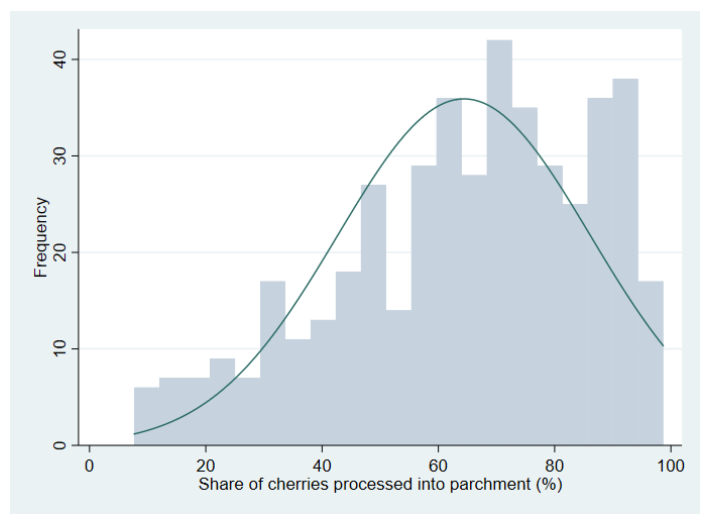

(b) Truncated at lower and upper bounds

Both normal and lognormal truncated models assume that the decisions in the first and second stage are independent conditional on the observed covariates 
(Wooldridge, 2010). However, one could imagine some common unobserved factors to affect both the decision to produce parchment and the extent of parchment produced. A modified double-hurdle model, known as the exponential type II Tobit model (Wooldridge, 2010), allows conditional correlation between the two decisions. The type II Tobit allows for the flexibility to incorporate conditional correlation off the log-transformed continuous dependent variable. While the exponential type II Tobit comes at the cost of not specifying a proper density, allowing negative outcomes on the dependent variable (Wooldridge, 2010), this is unlikely in our case given that the lower bound on the distribution of the share of cherries taken up by parchment (for those who produce strictly positive amounts of parchment) is relatively far from zero (Figure 3.1). We also estimate our model using the exponential type II Tobit to check robustness of the results. We interpret marginal effects from Cragg's normal truncated model. Conditional marginal effects (on the first-hurdle decision being positive) are calculated following Burke (2009).

\subsection{Data}

We collected primary data from coffee growing households in the district of Kapchorwa in eastern Uganda in the months of March and April 2018. Households were randomly selected from a list of coffee farmer groups obtained from the largest coffee exporter in eastern Uganda that has operated in the project region for approximately 20 years and dominates coffee markets in the region (UCDA, 2020). Our final sample consists of about 1610 households across 190 villages in 19 parishes of the district.

Key outcome variables are coffee revenues per kilogramme and profits per kilogramme. Total coffee revenues are calculated by summing up coffee revenues earned each day in which a given household engaged in coffee sales throughout the season. Coffee revenues on a given day is calculated by multiplying the quantity of coffee sold (either coffee cherries or parchment) by the respective price received for the type of coffee sold. Total cost includes cost incurred for harvesting coffee, post-harvest processing, and transport costs for marketing coffee each time the household sold their coffee. We calculate coffee revenues per kilogramme $\left(r_{i}\right)$ and profits per kilogramme $\pi_{i}$ as follows: 
$r_{i}=\frac{\sum_{d=1}^{D} q_{i, d} p_{i, d}}{H_{i}}$

$\pi_{i}=\frac{\sum_{d=1}^{D} q_{i, d} p_{i, d}-C_{i}}{H_{i}}$

where

$q_{i, d}=$ Quantity of coffee sold on day $d$ by household $i$

$p_{i, d}=$ Price received for coffee sold on day $d$ by household $i$

$H_{i}=$ Total quantity of coffee cherries harvested by household $i$

$C_{i}=$ Total cost incurred by household $i$ (harvest, post-harvest, and transport costs)

Parchment production is analysed as a binary indicator variable that takes the value of one if the household produces any parchment and zero otherwise. For the share of parchment produced (out of all harvested cherries) we divided the quantity of cherries processed to produce parchment by all the cherries harvested in kiprogramme by each household multiplied by 100 .

In our exploratory approach, we consider several factors that might be associated with parchment production. Our explanatory variables include knowledge on coffee quality which is measured by a count variable (0-10) constructed using questions on improved harvest practices and coffee quality. Correct answers to these 10 questions were scored 0 for incorrect answers and 1 for correct answers. The variable on coffee quality knowledge was then obtained as the sum of $0-1$ coded answers to the coffee-quality questions. This is a common approach to measuring knowledge in the literature (Kondylis et al., 2017; Hoerner et al., 2019).

Following Laajaj and Macours (2017) we use the Raven's progressive matrices (Raven, 1936) as a measure of cognitive ability. Specifically, we used a count variable (0-10) constructed by summing the scores given for answers to Raven's progressive matrices tests (0-5) and math tests (0-5). Knowledge and cognitive ability test questions are presented in the appendix.

We proxy market access with distance in kilometres to the nearest buying centre to which farmers transport their coffee. The answers of households that did not transport coffee to buying centres or those who reported to not have knowledge about the distance are replaced by village averages. To proxy coffee quality, we incorporated data on altitude, captured by the tablets used for data collection during the interview, and pest and disease pressure, measured using a categorical vari- 
able for the share of coffee harvest negatively affected by pests and diseases. We also have a range of data on household and farm characteristics as socio-economic control variables. As a general rule, we replaced incorrect entries by mean values of the variables.

\subsubsection{Summary Statistics}

Table 3.1 presents sample characteristics. We have a total of 1610 coffee farming households in our sample. Of all households in our sample, 955 sell coffee cherries exclusively (59 percent) whilst 451 (28 percent) sell both coffee cherries and parchment and 204 (13 percent) sell only parchment. For the group of households that sell both coffee cherries and coffee parchment, the share of cherries taken up by parchment varies between 8 percent and 99 percent with a mean of 64 percent. There are large differences between households who engage with parchment production and those that do not. For instance, households who produce only parchment earn 1049 Ushs per kilogramme of coffee harvested, whereas households that sell only cherries earn 1225 Ushs per kilogramme (p-value for difference $=0.000$ ). The difference in average profits when normalised by harvest levels is even higher between producers who engage with parchment and those who do not (740 versus 1039 UShs with a p-value of 0.000 for difference). On the other hand, households who produce parchment own larger coffee farms and, as a result, they harvest larger amounts of coffee. Total profits of parchment producers are, on average, higher (1.5 million UShs) than those who sell only fresh cherries (600,000 UShs). Households that produce both cherries and parchment earn 1127 UShs per kilogramme of coffee and 865 UShs as profits, which lie between what is earned by producers who sell only cherries and only parchment. Note that these are also the farmers who have significantly higher knowledge about coffee quality and cognitive ability than the rest of the farmers in the sample.

Regarding physical characteristics, parchment producers are from lower altitudes and affected by pest and disease pressure to a larger extent on average. This is in line with our hypothesis that households from lower-quality regions are more likely to produce parchment due to the presence of quality thresholds in the coffee cherry market. Households who produce parchment have a higher number of pulping machines in their farmer group than the cherry producers. Market access, as measured by the distance to the buying centre, is similar across groups. Note, however, that this distance measure is subject to rounding (such as 10 and 20) and may be imprecise as the distance is estimated by the respondent and not necessarily measured. There are no large differences between parchment produc- 
Table 3.1: Sample characteristics across producer categories

\begin{tabular}{lcccccccc}
\hline \hline & \multicolumn{2}{c}{$\begin{array}{c}\text { Total } \\
(\mathrm{N}=1610)\end{array}$} & \multicolumn{2}{c}{$\begin{array}{c}\text { Only } \\
\text { parchment } \\
(\mathrm{N}=201)\end{array}$} & $\begin{array}{c}\text { Cherries and } \\
\text { parchment } \\
(\mathrm{N}=451)\end{array}$ & \multicolumn{2}{c}{$\begin{array}{c}\text { Only } \\
\text { cherries } \\
(\mathrm{N}=955)\end{array}$} \\
& Mean & St dev & Mean & St dev & Mean & St dev & Mean & St dev \\
\hline Revenues per kg (Ushs) & 1175 & 163 & 1049 & 112 & 1127 & 104 & 1225 & 173 \\
Profits per kg (Ushs) & 952.2 & 311.6 & 740.2 & 273.9 & 864.3 & 289.5 & 1038.9 & 295.7 \\
Share of cherries processed (\%) & 30.7 & 40.2 & 100.0 & 0.0 & 64.4 & 21.7 & 0.0 & 0.0 \\
Coffee harvest in kg & 884 & 1259 & 1550 & 1893 & 1323 & 1557 & 535 & 676 \\
Coffee farm size in acres & 1.5 & 1.2 & 1.6 & 1.2 & 1.8 & 1.5 & 1.3 & 0.9 \\
Experience with coffee farming & 26.2 & 14.3 & 27.3 & 15.2 & 28.0 & 14.0 & 25.2 & 14.1 \\
Altitude in metres & 1776 & 213 & 1737 & 188 & 1780 & 181 & 1782 & 231 \\
Pest and disease pressure (0-7) & 1.0 & 0.5 & 1.2 & 0.5 & 1.1 & 0.5 & 1.0 & 0.5 \\
Number of pulpers in the group & 1.3 & 1.4 & 1.9 & 1.6 & 1.4 & 1.5 & 1.1 & 1.2 \\
Quality knowledge score (0-10) & 4.9 & 1.8 & 5.0 & 1.7 & 5.3 & 2.0 & 4.7 & 1.8 \\
Knowledge parchment (0/1) & 0.5 & 0.5 & 0.5 & 0.5 & 0.4 & 0.5 & 0.5 & 0.5 \\
Cognitive ability score (0-10) & 4.0 & 2.3 & 3.9 & 2.3 & 4.2 & 2.3 & 4.0 & 2.3 \\
Distance to buying centre in km & 15.3 & 8.3 & 14.6 & 5.0 & 14.5 & 8.5 & 15.9 & 8.7 \\
HH size & 6.4 & 2.4 & 6.3 & 2.2 & 6.7 & 2.4 & 6.2 & 2.5 \\
Female household head (0/1) & 0.1 & 0.3 & 0.1 & 0.3 & 0.2 & 0.4 & 0.1 & 0.3 \\
HH head age in years & 52.3 & 13.6 & 53.4 & 13.6 & 52.8 & 13.4 & 51.8 & 13.6 \\
HH head education in years & 8.9 & 5.6 & 8.8 & 5.5 & 9.3 & 5.5 & 8.8 & 5.6 \\
Number of HH assets per capita & 0.4 & 0.4 & 0.5 & 0.4 & 0.5 & 0.4 & 0.4 & 0.4 \\
Crop sales per capita (UShs) & 193.6 & 314.7 & 237.5 & 312.0 & 210.3 & 293.0 & 176.3 & 324.0 \\
\hline \hline
\end{tabular}

Notes: UShs refers to Ugandan Shillings. 3600 UShs $\sim 1$ USD

ers and cherry producers in terms of household characteristics, such as sex, age or education of the household head and household assets, except that parchment producers are on average have higher revenues earned from sales of other crops (than coffee) compared to fresh cherry producers.

\subsection{Results}

In this section we first seek to establish that parchment production is associated with lower revenues and profits. We model revenues and profits per kilogramme, first, as a function of participation in parchment production and, second, as a function of the extent to which households engage with parchment production. In the second subsection we present results from an analysis of factors that predict the decision to participate in parchment markets, and on the factors that explain the variation in parchment quantity for those households who do produce parchment.

\subsubsection{Revenues and profits per kilogram}

The estimated effects of parchment production on the two outcome variables revenues and profits per kilogramme of coffee harvested are summarised in Table 3.2 while full specifications are presented in Table 3.6 and Table 3.7. Presented 
specifications from OLS and IV estimations include coffee quality-related factors and household characteristics. OLS estimation in Column 1 shows that producing parchment is negatively associated with revenues earned per kilogramme of coffee harvested. In particular, engaging with parchment production is associated with a decrease of 129 UShs ( $\sim 0.38$ USD) in revenues earned per kilogramme.

Table 3.2: Revenues and profits per kg explained by participation in parchment production

\begin{tabular}{lcccc}
\hline \hline & \multicolumn{3}{c}{ Revenues per kg (Ushs) } & \multicolumn{2}{c}{ Profits per kg (Ushs) } \\
\hline & OLS & 2SLS & OLS & 2SLS \\
& $(1)$ & $(2)$ & $(3)$ & $(4)$ \\
\hline & & & & \\
Produce parchment $(0 / 1)$ & $-128.5^{* * *}$ & $-248.3^{* * *}$ & $-226.1^{* * *}$ & $-307.2^{* * *}$ \\
& $(7.372)$ & $(69.71)$ & $(15.92)$ & $(116.4)$ \\
& & & & \\
HH and farm controls & Yes & Yes & Yes & Yes \\
Observations & 1,610 & 1,610 & 1,610 & 1,610 \\
R-squared & 0.160 & 0.038 & 0.124 & 0.109 \\
F-stat & & 32.644 & & 32.644 \\
\hline Comparison group & $1,225^{* * *}$ & \multicolumn{3}{c}{$1,039^{* * * *}$} \\
mean (no parchment) & $(6.860)$ & \multicolumn{3}{c}{$(11.645)$} \\
\hline \hline
\end{tabular}

Notes: OLS and IV estimations. UShs refers to Ugandan Shillings. 3600 UShs $\sim 1$ USD. HH and farm controls include coffee harvest in kg, coffee farm size in acres, experience with coffee farming in years, pest and disease pressure, altitude in metres, distance to buying centres in $\mathrm{km}$, household size, sex and education of the household head, and number of assets and crop sales per capita. Standard errors are clustered at the village level and are reported in parentheses. $* * * \mathrm{p}<0.01, * * \mathrm{p}<0.05, * \mathrm{p}<0.1$

Results from the IV estimation show that engaging with parchment reduces revenues per kilogramme by 248 UShs (Column 2) indicating that coffee revenues per kilogramme are much lower for farmers who engage with parchment than those who sell only fresh cherries. To put in the context, farmers who produce only parchment earn about 1225 UShs per kilogramme. Estimates for the effects of parchment production on revenues per kilogramme correspond to, in the OLS case, 10 percent and, in the IV case, 20 percent of revenues earned by farmers who do not engage with parchment production.

Given that farmers make their marketing decisions based on not only output prices but also costs associated with participation, we also seek to establish whether parchment production reduces profits (which include harvest, post-harvest and transport costs). Profit specifications also include farm and household controls. Results indicate that the negative impact of parchment production on revenues per kilogramme of harvested cherries also holds for profits. OLS results show 
that producing parchment is associated with a 226 UShs decrease in coffee profits (Columns 3). IV estimates show larger effects. Engaging with parchment production causes a reduction in profits per kilogramme of 307 UShs on average (Column 4). Average profits per kilogramme earned by farmers who produce solely parchment are about 1039 UShs. Estimates for the effects of parchment production on profits correspond to, in the OLS case, 22 percent and, in the IV case, 30 percent of profits earned by farmers who engage only with parchment production.

Table 3.3: Revenues and profits per kilogramme explained by the extent of parchment production

\begin{tabular}{lcccc}
\hline \hline & \multicolumn{2}{c}{ Revenues per kg (Ushs) } & \multicolumn{2}{c}{ Profits per kg (Ushs) } \\
\hline & OLS & 2SLS & OLS & 2SLS \\
& $(1)$ & $(2)$ & $(3)$ & $(4)$ \\
\hline $\begin{array}{l}\text { Share of cherries processed } \\
\text { into parchment (\%) }\end{array}$ & $-1.754^{* * *}$ & $-2.283^{* * *}$ & $-2.942^{* * * *}$ & $-2.825^{* * *}$ \\
& $(0.0896)$ & $(0.525)$ & $(0.188)$ & $(1.075)$ \\
HH and farm controls & Yes & Yes & Yes & Yes \\
Observations & 1,610 & 1,610 & 1,610 & 1,610 \\
R-squared & 0.198 & 0.182 & 0.142 & 0.141 \\
F-stat & & 57.778 & & 57.778 \\
\hline \hline
\end{tabular}

Notes: OLS and IV estimations. UShs refers to Ugandan Shillings. 3600 UShs $\sim 1$ USD. HH and farm controls include coffee harvest in $\mathrm{kg}$, coffee farm size in acres, experience with coffee farming in years, pest and disease pressure, altitude in metres, distance to buying centres in $\mathrm{km}$, household size, sex and education of the household head, and number of assets and crop sales per capita. Standard errors are clustered at the village level and are reported in parentheses. ${ }^{* * *} \mathrm{p}<0.01,{ }^{* *} \mathrm{p}<0.05,{ }^{*} \mathrm{p}<0.1$

After establishing participation in parchment markets reduces coffee earnings, we turn to assessing how variation in the extent of parchment production affects revenues and profits per kilogramme. Table 3.3 summarises the OLS and IV estimation results. Column 1 of Table 3.3 shows that a one percentage point increase in the share of cherries produced into parchment is associated with a decrease of 1.8 UShs in average prices. As earlier, IV estimates are larger. One percentage point increase in the share of cherries taken up by parchment reduces revenues per kilogramme of harvested cherries by 2.8 UShs (Column 2). Column 3 and 4 of Table 3.3 present the effects on profits. The effects on profits per kilogramme are higher by 2.9 UShs, as expected, since processing is associated with costs. All results are robust to inclusion of region fixed-effects (full specifications are presented in Table 3.6 and Table 3.7 in section 3.7). Overall, OLS and IV estimates are similar in terms of direction and significance, and indicate strongly negative effects of parchment production on profits per kilogramme. At lower shares of 
parchment production this represents a small portion of profits. For farmers who process 100 percent of the harvest into parchment, on the other hand, the effect is substantial, supporting the "value degrading" hypothesis.

\subsubsection{Drivers of parchment production}

In this section we explore the factors that explain parchment production. We first present results from the estimation of the decision to participate in the parchment market. Then, conditional on participation in the parchment market, we present results for the estimation of second-stage models for the extent to which households engage with parchment, measured by the share of cherries processed into parchment. Results for participation in the parchment market (0/1) are shown in Table 3.4 whilst those for the second-stage models are presented in Table 3.5.

Coffee quality is likely to be associated with the production of parchment given the common requirement that coffee cherries presented for sale must be above a minimum quality. Elevation is a key factor that affects coffee quality to a large extent (Decazy et al., 2003). Results confirm that there is a negative relationship between coffee quality and the probability of producing parchment. Households that are from lower-quality areas, i.e. lower altitudes and with higher pest and disease pressure are more likely to engage in parchment production (Table 3.4) and are associated with higher share of coffee harvest taken up by parchment (Table 3.5). Additionally, households who hire picking labour are more likely to produce parchment. Apart from the farm size effects (larger farms are more likely to require more labour), one plausible explanation is that pickers do not harvest high quality cherries. Hired pickers are paid per basket of cherries they fill, which incentivises them to pick quickly and unselectively reducing the quality of cherries harvested (and monitoring each picker during harvest is costly). These findings indicate that quality requirements in the cherry market may be constraining fresh cherry sales and leading to higher levels of parchment production.

Lack of information is commonly identified as a barrier to adoption of welfareimproving practices. In this case, we seek to establish whether a lack of knowledge about coffee quality is associated with parchment production. Our results show that coffee quality knowledge is positively associated with the probability of engaging with parchment. Scoring one point higher on the coffee quality knowledge test is associated with a 2 percentage points increase in the likelihood of engaging with parchment production. On the other hand, knowledge about coffee quality is decreasing in the share of cherries taken up by parchment. While it may 
seem counter-intuitive at first glance, this finding indicates that farmers who have higher levels of coffee quality sell both fresh cherries and parchment. One plausible explanation is that growers who know well about coffee quality can identify and home-process the cherries which are likely to fall below the quality threshold in the cherry market (and cannot be marketed).

Table 3.4: Participation in parchment production. First-stage probit estimations

\begin{tabular}{|c|c|c|c|c|}
\hline & \multicolumn{4}{|c|}{ Produce parchment $(0 / 1)$} \\
\hline & $\begin{array}{c}\text { First-stage } \\
\text { coefficients } \\
\text { (1) }\end{array}$ & $\begin{array}{l}\text { Marginal } \\
\text { Effects } \\
(2)\end{array}$ & $\begin{array}{l}\text { First-stage } \\
\text { coefficients } \\
\text { (3) }\end{array}$ & $\begin{array}{l}\text { Marginal } \\
\text { Effects } \\
\text { (4) }\end{array}$ \\
\hline Quality knowledge score (0-10) & $\begin{array}{c}0.0629 * * * \\
(0.0192)\end{array}$ & $0.0210 * * *$ & $\begin{array}{c}0.0632 * * * \\
(0.0194)\end{array}$ & $0.0207 * * *$ \\
\hline Parchment knowledge $(0 / 1)$ & $\begin{array}{l}-0.218 * * * \\
(0.0681)\end{array}$ & $-0.0727 * * *$ & $\begin{array}{c}-0.209 * * * \\
(0.0686)\end{array}$ & $-0.0686 * * *$ \\
\hline Cognitive ability score $(0-10)$ & $\begin{array}{l}-0.0192 \\
(0.0158)\end{array}$ & -0.006 & $\begin{array}{l}-0.0197 \\
(0.0160)\end{array}$ & -0.006 \\
\hline Distance to buying centre in $\mathrm{km}$ & $\begin{array}{l}-0.0075^{*} \\
(0.0041)\end{array}$ & $-0.0025^{*}$ & $\begin{array}{l}-0.0072 * \\
(0.0042)\end{array}$ & $-0.0024^{*}$ \\
\hline Coffee harvest in $\mathrm{kg}$ & $\begin{array}{l}0.0005 * * * \\
(0.00004)\end{array}$ & $0.0002 * * *$ & $\begin{array}{l}0.0005 * * * \\
(0.00005)\end{array}$ & $0.0002 * * *$ \\
\hline Altitude in meters & $\begin{array}{l}-0.0004 * * \\
(0.0001)\end{array}$ & $-0.0001 * *$ & $\begin{array}{c}-0.0012 * * * \\
(0.0002)\end{array}$ & $-0.0004 * * *$ \\
\hline Pest and disease pressure $(0-7)$ & $\begin{array}{c}0.176 * * \\
-0.072\end{array}$ & $0.059 * *$ & $\begin{array}{l}0.243 * * * \\
-0.0848\end{array}$ & $0.071 * * *$ \\
\hline Hire labour $(0 / 1)$ & $\begin{array}{l}0.224 * * * \\
(0.0713)\end{array}$ & $0.0745 * * *$ & $\begin{array}{l}0.233 * * * \\
(0.0722)\end{array}$ & $0.0765 * * *$ \\
\hline Experience with coffee farming & $\begin{array}{c}0.0105 * * * \\
(0.0025)\end{array}$ & $0.0035 * * *$ & $\begin{array}{c}0.0096 * * * \\
(0.0025)\end{array}$ & $0.0031 * * *$ \\
\hline HH size & $\begin{array}{l}0.0369 * * \\
(0.0145)\end{array}$ & $0.0123 * *$ & $\begin{array}{l}0.0339 * * \\
(0.0146)\end{array}$ & $0.0111 * *$ \\
\hline Crop sales per capita (000 UShs) & $\begin{array}{l}0.00002 \\
(0.0001)\end{array}$ & 0.00001 & $\begin{array}{l}0.00002 \\
(0.0001)\end{array}$ & 0.00001 \\
\hline Region fixed-effects & No & & Yes & \\
\hline Observations & 1,610 & & 1,610 & \\
\hline
\end{tabular}

Notes: Standard errors are clustered at the village level and reported in parentheses. $* * * *$ $\mathrm{p}<0.01, * * \mathrm{p}<0.05, * \mathrm{p}<0.1$

Additionally, given that only about half of the producers know roughly how many kiprogramme of coffee cherries need to be processed to produce a kilogramme of dried parchment, we suggest that there may be informational barriers about the effective cost of input required for parchment production and thus about the effective price differentials between fresh cherries and parchment coffee leading to a higher likelihood of participation in parchment markets. Our results show that knowledge about effective cost of parchment is negatively associated with parchment production. In particular, farmers who know how many kiprogramme of 
cherries need to be processed to produce one kilogramme of dried parchment are 7 percentage points less likely to produce parchment. This result is highly significant.

Table 3.5: Second-stage coefficients and marginal effects estimated with truncated normal model

\begin{tabular}{|c|c|c|c|c|}
\hline & \multicolumn{4}{|c|}{ Share of cherries processed into parchment (\%) } \\
\hline & $\begin{array}{l}\text { Second-stage } \\
\text { coefficients } \\
\text { (1) }\end{array}$ & $\begin{array}{l}\text { Marginal } \\
\text { Effects } \\
(2)\end{array}$ & $\begin{array}{l}\text { Second stage } \\
\text { coefficients } \\
\text { (3) }\end{array}$ & $\begin{array}{l}\text { Marginal } \\
\text { Effects } \\
\text { (4) }\end{array}$ \\
\hline Quality knowledge score (0-10) & $\begin{array}{c}-1.496 * * * \\
(0.520)\end{array}$ & $-1.481^{* *}$ & $\begin{array}{c}-1.482 * * * \\
(0.520)\end{array}$ & $-1.466 * *$ \\
\hline Parchment knowledge $(0 / 1)$ & $\begin{array}{c}0.546 \\
(1.904)\end{array}$ & 0.541 & $\begin{array}{c}0.568 \\
(1.903)\end{array}$ & 0.562 \\
\hline Cognitive ability score $(0-10)$ & $\begin{array}{c}-1.206 * * * \\
(0.435)\end{array}$ & $-1.193 * *$ & $\begin{array}{c}-1.210 * * * \\
(0.436)\end{array}$ & $-1.198 * *$ \\
\hline Distance to buying centre in $\mathrm{km}$ & $\begin{array}{l}-0.134 \\
(0.123)\end{array}$ & -0.132 & $\begin{array}{l}-0.130 \\
(0.126)\end{array}$ & -0.129 \\
\hline Coffee harvest in $\mathrm{kg}$ & $\begin{array}{c}0.0016 * * * \\
(0.0006)\end{array}$ & 0.0016 & $\begin{array}{c}0.0016 * * * \\
(0.0006)\end{array}$ & 0.002 \\
\hline Altitude in meters & $\begin{array}{c}-0.015 * * * \\
(0.005)\end{array}$ & $-0.014 * * *$ & $\begin{array}{c}-0.019 * * * \\
(0.006)\end{array}$ & $-0.019 * *$ \\
\hline Pest and disease pressure (0-7) & $\begin{array}{c}7.473 * * * \\
-1.996\end{array}$ & $7.392 * *$ & $\begin{array}{c}10.05^{* * * *} \\
-2.343\end{array}$ & $9.936 * * *$ \\
\hline Hire labour $(0 / 1)$ & $\begin{array}{l}0.0401 \\
(2.011)\end{array}$ & 0.0397 & $\begin{array}{c}0.177 \\
(2.026)\end{array}$ & 0.175 \\
\hline Experience with coffee farming & $\begin{array}{c}-0.103 \\
(0.0670)\end{array}$ & -0.102 & $\begin{array}{c}-0.106 \\
(0.0671)\end{array}$ & -0.105 \\
\hline HH size & $\begin{array}{c}-1.429 * * * \\
(0.410)\end{array}$ & $-1.415 * * *$ & $\begin{array}{c}-1.445 * * * \\
(0.412)\end{array}$ & $-1.430 * * *$ \\
\hline Crop sales per capita (000 UShs) & $\begin{array}{c}0.0039 \\
(0.0033)\end{array}$ & 0.0038 & $\begin{array}{c}0.0038 \\
(0.0033)\end{array}$ & 0.0038 \\
\hline Region fixed-effects & No & & Yes & \\
\hline Sigma & $23.555^{* * * *}$ & & $23.538 * * *$ & \\
\hline Log-likelihood & -3923.4934 & & -3908.7307 & \\
\hline Wald chi2 & $250.64 * * *$ & & $271.5 * * *$ & \\
\hline Observations & 1,610 & & 1,610 & \\
\hline
\end{tabular}

Notes: Standard errors are clustered at the village level and reported in parentheses. $* * *$ $\mathrm{p}<0.01, * * \mathrm{p}<0.05, * \mathrm{p}<0.1$

Cognitive ability, associated with socio-economic success, may ease such information constraints and be associated with parchment production decisions. We find a negative and significant relationship between cognitive ability and the share of cherries taken up by parchment. It appears that farmers with higher cognitive ability tend to engage in parchment market to a lesser extent. One could imagine that those who have higher cognitive ability are also knowledgeable about coffee quality and are able to understand the characteristics of cherry and parchment markets. Hence, it may well be the case that they produce relatively a smaller 
amount of parchment and possibly using lower quality cherries which might fail to be marketed in the cherry market. In fact, farmers who report to produce parchment using lower quality cherries (Table 3.8 ) also have significantly higher knowledge scores and cognitive ability scores than the rest of the producers (Table 3.9). These small groups of growers, who produce parchment using only lower quality cherries, also have significantly higher coffee profits than the rest of the parchment producers ( $p$-value $=0.002$ ) but still lower than the farmers who only sell fresh cherries (p-value $=0.000)$. This suggests that farmers with certain characteristics might be taking advantage of the quality uncertainty in the parchment market (adverse selection). Whilst Akerlof's (1970) theory predicts a race to the bottom and eventual market collapse, later Miyazaki (1977) and Wilson (1977) demonstrated that in the presence of asymmetric information and quality uncertainty, market prices stabilise at average rates. This results in low-risk individuals (good parchment sellers) subsidizing high-risk individuals (bad parchment sellers), perfectly in line with our findings.

Distance to buying centres is another factor likely to affect coffee cherry sales through increasing the transaction costs of fresh coffee sales (as they are highly perishable) versus dried parchment sales. Results show, however, that distance to buying centres is only marginally significantly associated with participating in parchment markets and not with the share of cherries processed to produce parchment. Anecdotal evidence and focus group discussions suggest that market access is typically not a problem for most farmers as there are many buying centres across the district.

Lastly, quantity of coffee harvested significantly predicts parchment production. Households with higher quantities of coffee harvest are more likely to engage with parchment production. This may indicate, among others, market capacity constraints. We have anecdotal evidence from our qualitative interviews that in the peak season the cherry market may saturate and the largest exporter may stop buying cherries in the late afternoon due to a lack of capacity of processing cherries. This would give growers no option but to home-process harvested cherries leading to parchment sales. Whilst such instances do not happen very often (only a few times during the whole season), cannot be predicted, and thus usually come as a surprise, it might nonetheless tilt the scale towards parchment production for large producers. One might wonder why this would affect larger producers. One plausible explanation is that farmers with smaller farms can harvest cherries relatively quickly (this includes picking the cherries which may take up to a full 
working day, paying pickers according to the quantity they picked, weighing cherries and arranging transport). Hence, compared to the farmers with large amounts of produce, smaller scale growers can make it to the buying centres relatively early in the day, possibly before the buyers stops buying.

Table 3.12 presents the estimated coefficients of the key variables using twopart models such as Cragg's truncated normal, double-bounded truncated normal, truncated lognormal, and exponential type II Tobit. All models yield similar coefficients in terms of direction, size, and significance indicating robustness of the results.

\subsection{Conclusion}

Analysing primary data collected from 1610 Arabica coffee farmers in the Mount Elgon region of Uganda, we considered the role of partial processing of Arabica coffee by farming households into parchment coffee as an upgrading activity. In particular, we established the extent to which costly and time-consuming parchment production generates lower revenues and profits for coffee-farming households. The hypothesis that parchment production would yield lower revenues per kilogramme (equivalent prices) compared to the sale of fresh coffee cherries was mainly based on the concept of the "market for lemons" proposed by Akerlof (1970). Akerlof outlines how a market for a product which is associated with quality uncertainty and asymmetric information between the buyer and the seller could generate a case in which quality and prices of the products tend to go down.

We applied an instrumental variable strategy to consider the extent to which Arabica coffee producers receive lower average revenues per kilogramme of harvested coffee when they produce more of their coffee production as parchment compared to fresh cherries. Results show that processing fresh coffee cherries to produce a more complex coffee product, parchment coffee, reduces coffee revenues and profits earned. In particular, participation in parchment markets generates an average decrease of up to one third of revenues. The negative effect on profits is even larger since processing cherries into parchment is associated with labour and capital costs. These findings are in line with the conclusions of Gibbon and Ponte (2005) and Ponte and Ewert (2009) that the rewards for value addition are not always clear for producers. However, this study provides the first causal evidence on relative effects of processing a fresh coffee produce into a sophisticated product on revenues and profits at the household level. 
Vicol et al. (2018) rationalise unprofitable processing of coffee for primary producers based on smallholder farmers' incapacity to produce higher quality coffee products. Our quantitative findings also point out the centrality of quality issues to the coffee sector. We estimate double-hurdle models that would provide insights into the drivers of parchment production by smallholder coffee farmers in our sample. Our analysis indicates a number of factors strongly associated with participation and the extent of participation in the parchment market. Product quality indeed explains parchment production for a number of growers. Lowerquality farms, such as those from lower altitudes and affected by pest and diseases, are more likely to produce parchment and higher levels of parchment conditional on producing parchment. Relatedly, hiring pickers - who are typically paid based on quantity and not quality of the coffee harvested - is positively associated with parchment production. We thus recommend interventions to improve coffee quality in the region so that farmers can sell all of their cherries fresh and earn higher revenues. Whilst land markets are rigid and altitude cannot be changed, coffee quality can substantively be improved through attending the gardens better to reduce the damage made to coffee quality by pest and diseases. In addition, improving harvest practices through selective picking is key for coffee quality. Hence, introducing extension programs which pay special attention to improving coffee quality would help farmers benefit from higher value export markets, given the growing international demand for high-quality coffee and excess supply of lowquality coffee products.

It is critical that extension services be complemented by incentives for high quality. Increasing quality of coffee cherries is only viable and sustainable when monetary incentives for higher quality are in place. Efforts should be made for a more efficient value chain that rewards quality for value chain actors starting from the farm labourers who harvest coffee. Hired labour for picking coffee is paid for quantity which results in quick and low-quality coffee harvested. This can be resolved by providing monetary incentives for high-quality picking. Farmers would incentivise farm labourers if they were rewarded objectively for their coffee quality by the buyers. As a result, to address such inefficiencies in the market, a value chain intervention which encourages paying for high-quality coffee through using an effective and objective quality measurement tool at all stages should be introduced. Note that such interventions have substantial implications on livelihoods not only for the producers in the coffee sector but for many sectors across the world. For instance, Saenger et al. (2014) show how a quality-verification intervention increases the quality of milk produced along with household consumption 
by smallholder dairy farmers in Vietnam.

Results also indicate presence of farmers who produce parchment using only lower quality cherries and sell the low-quality parchment nonetheless, which is due to difficulties in ascertaining quality of parchment coffee. Quality uncertainty and asymmetric information substantially undermine the efficiency of the value chain and addressing this require efforts and interventions at the broader level. Such interventions may include introduction of tighter monitoring/regulations for processing coffee. For instance, Costa Rica adopted a nation-wide policy and, taking necessary actions, established itself as a producer of high-quality coffee. Primary producers in Costa Rica do not process coffee cherries and must instead sell their produce to cooperatives for processing while cooperatives are heavily monitored to ensure quality standards (Wollni and Zeller, 2007). A similar strategy has been adopted in Rwanda. Producers are encouraged to market their cherries fresh and cooperatives are the main processors of coffee cherries (Mujawamariya et al., 2013). Given that Ugandan coffee market is highly liberal, producers should be incentivised by higher prices to increase the quality of their coffee (price discrimination with respect to quality) and market their cherries fresh.

Last but not least, we show that larger farms engage with parchment production to a greater extent. We also have anecdotal evidence that cherry processing capacity is limited and buyers may unexpectedly stop buying cherries in peak season. Larger farmers are likely disproportionately affected from market capacity constraints since a longer time is required for harvesting big gardens which delays marketing cherries on a given day. Moreover, market capacity constraints and the ensuing need for producers to reach the buyer early in the day may hinder coffee quality in the region by reducing the time invested in selective picking of coffee for higher quality regardless of the size of the farm. As a result, our findings suggest a major role for the private sector (processors and exporters) and authorities regarding investment in increasing the capacity of processing facilities so that thousands of smallholder producers can participate in higher value coffee markets and earn substantially higher incomes.

In sum, we conclude that, to improve the welfare of producers in developing countries, promotion of value upgrading activities should be undertaken with care and, more critically, activities aiming at moving growers up the value chain need to be integrated with relevant characteristics of the supply chain, such as qualityassurance. 


\subsection{Additional figures and tables}

Figure 3.2: Households in our sample across production categories

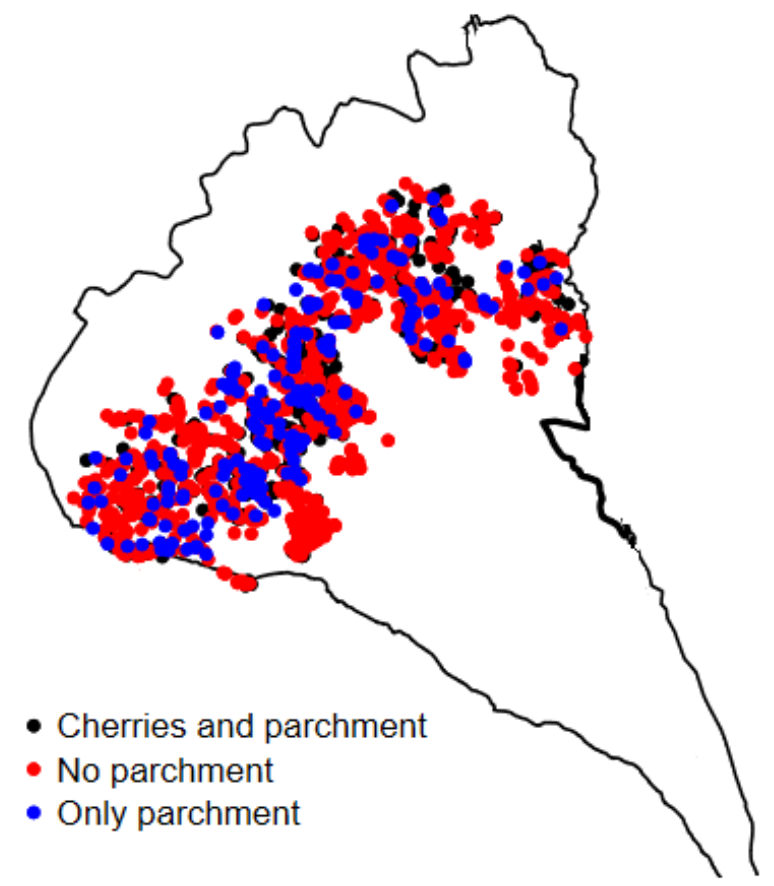


Figure 3.3: Products and activities in the (washed) Arabica coffee value chain

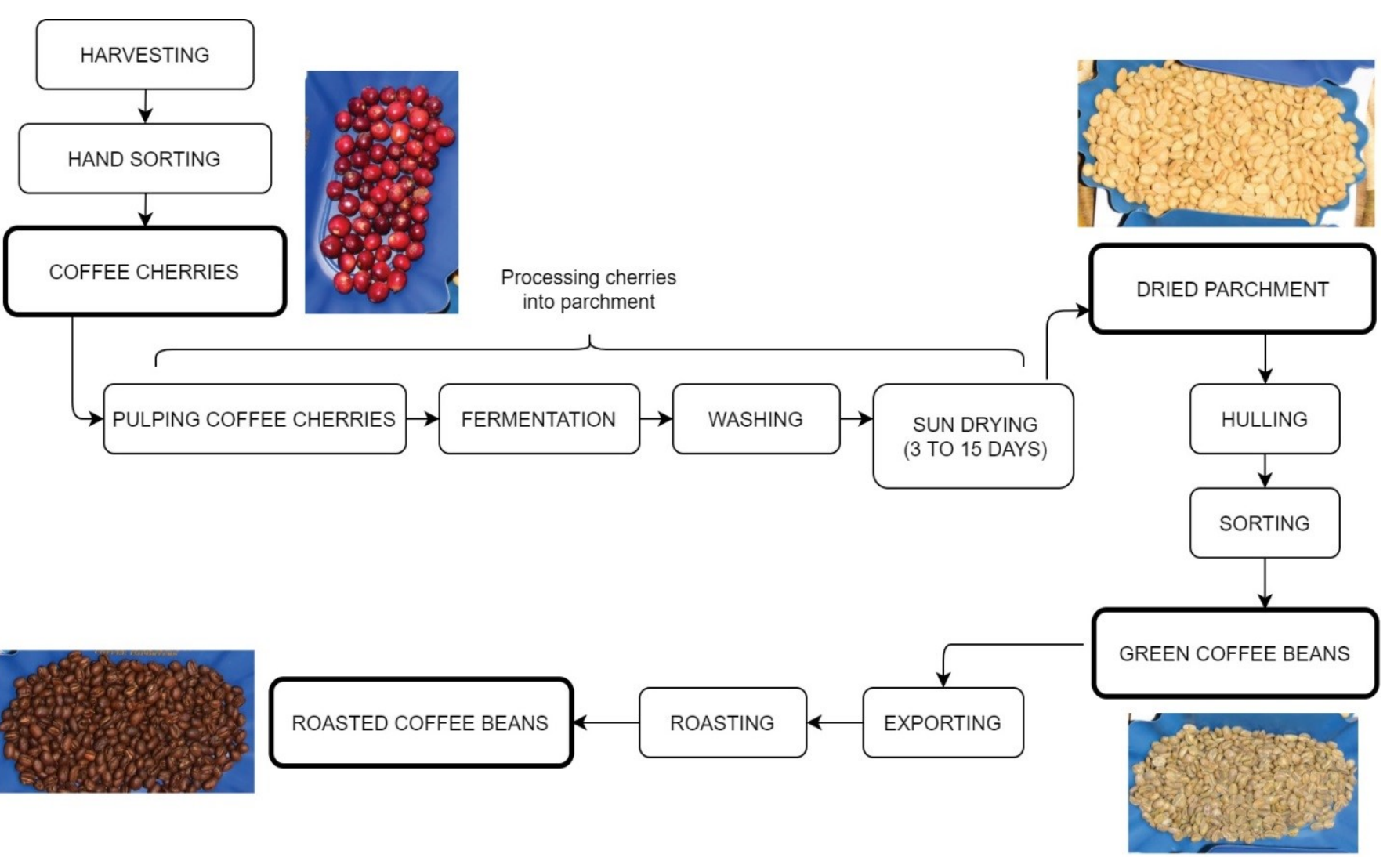


Table 3.6: Coffee revenues per kg (UShs). Full Specification

\begin{tabular}{|c|c|c|c|c|c|c|c|c|}
\hline & \multicolumn{8}{|c|}{ "Revenues per kg (Ushs) } \\
\hline & $\begin{array}{l}\text { OLS } \\
(1)\end{array}$ & $\begin{array}{l}\text { OLS } \\
(2)\end{array}$ & $\begin{array}{l}\text { 2SLS } \\
\text { (3) }\end{array}$ & $\begin{array}{c}\text { 2SLS } \\
\text { (4) }\end{array}$ & $\begin{array}{l}\text { OLS } \\
(5)\end{array}$ & $\begin{array}{l}\text { OLS } \\
(6)\end{array}$ & $\begin{array}{l}\text { 2SLS } \\
(7)\end{array}$ & $\begin{array}{c}\text { 2SLS } \\
(8)\end{array}$ \\
\hline Sell parchment (0-1) & $\begin{array}{c}-128.0 * * * \\
(7.640)\end{array}$ & $\begin{array}{c}-128.5 * * * \\
(7.372)\end{array}$ & $\begin{array}{c}-248.3 * * * \\
(69.71)\end{array}$ & $\begin{array}{c}-263.8 * * * \\
(74.59)\end{array}$ & & & & \\
\hline $\begin{array}{l}\text { Share of cherries processed } \\
\text { into parchment }(\%)\end{array}$ & & & & & $\begin{array}{l}-1.754 * * * \\
(0.0896)\end{array}$ & $\begin{array}{l}-1.763^{* * * *} \\
(0.0865)\end{array}$ & $\begin{array}{l}-2.283 * * * \\
(0.525)\end{array}$ & $\begin{array}{l}-2.310 * * * \\
(0.540)\end{array}$ \\
\hline Coffee farm size in acres & $\begin{array}{c}10.48 * * * \\
(3.070)\end{array}$ & $\begin{array}{l}7.200 * * \\
(2.938)\end{array}$ & $\begin{array}{l}18.75 * * * \\
(5.920)\end{array}$ & $\begin{array}{l}15.88 * * \\
(6.172)\end{array}$ & $\begin{array}{l}9.747 * * * \\
(2.979)\end{array}$ & $\begin{array}{l}6.473 * * \\
(2.802)\end{array}$ & $\begin{array}{c}7.155 \\
(7.243)\end{array}$ & $\begin{array}{c}2.916 \\
(7.596)\end{array}$ \\
\hline Experience with coffee farming & $\begin{array}{c}0.259 \\
(0.294)\end{array}$ & $\begin{array}{c}0.304 \\
(0.291)\end{array}$ & $\begin{array}{l}0.735^{*} \\
(0.421)\end{array}$ & $\begin{array}{l}0.782^{*} \\
(0.420)\end{array}$ & $\begin{array}{c}0.209 \\
(0.279)\end{array}$ & $\begin{array}{c}0.246 \\
(0.276)\end{array}$ & $\begin{array}{c}0.984 \\
(0.624)\end{array}$ & $\begin{array}{c}1.012 \\
(0.647)\end{array}$ \\
\hline Altitude in metres & $\begin{array}{c}0.0849 * * * * \\
(0.0246)\end{array}$ & $\begin{array}{l}0.0747 * * \\
(0.0344)\end{array}$ & $\begin{array}{c}0.0752 * * * \\
(0.0276)\end{array}$ & $\begin{array}{l}-0.0060 \\
(0.0568)\end{array}$ & $\begin{array}{c}0.0821^{* * * *} \\
(0.0242)\end{array}$ & $\begin{array}{l}0.0639 * \\
(0.0342)\end{array}$ & $\begin{array}{c}0.0152 \\
(0.0419)\end{array}$ & $\begin{array}{c}0.0535 \\
(0.0899)\end{array}$ \\
\hline Pest and disease pressure & $\begin{array}{c}6.758 \\
(8.404)\end{array}$ & $\begin{array}{l}-13.24 \\
(9.009)\end{array}$ & $\begin{array}{c}15.79 \\
(11.40)\end{array}$ & $\begin{array}{l}-2.292 \\
(12.57)\end{array}$ & $\begin{array}{c}12.26 \\
(7.965)\end{array}$ & $\begin{array}{l}-7.151 \\
(8.811)\end{array}$ & $\begin{array}{c}5.100 \\
(16.94)\end{array}$ & $\begin{array}{l}-19.26 \\
(20.47)\end{array}$ \\
\hline Distance to buying centre & $\begin{array}{c}-0.00218 \\
(0.556)\end{array}$ & $\begin{array}{c}0.264 \\
(0.526)\end{array}$ & $\begin{array}{l}-0.446 \\
(0.575)\end{array}$ & $\begin{array}{l}-0.164 \\
(0.540)\end{array}$ & $\begin{array}{l}-0.0453 \\
(0.537)\end{array}$ & $\begin{array}{c}0.223 \\
(0.510)\end{array}$ & $\begin{array}{l}-0.642 \\
(0.880)\end{array}$ & $\begin{array}{l}-0.331 \\
(0.860)\end{array}$ \\
\hline $\mathrm{HH}$ size & $\begin{array}{c}1.861 \\
(1.505)\end{array}$ & $\begin{array}{l}2.692^{*} \\
(1.500)\end{array}$ & $\begin{array}{l}3.943^{*} \\
(2.254)\end{array}$ & $\begin{array}{l}4.783 * * \\
(2.195)\end{array}$ & $\begin{array}{c}1.093 \\
(1.477)\end{array}$ & $\begin{array}{c}1.874 \\
(1.467)\end{array}$ & $\begin{array}{c}3.930 \\
(3.501)\end{array}$ & $\begin{array}{c}4.812 \\
(3.531)\end{array}$ \\
\hline Female household head $(0 / 1)$ & $\begin{array}{l}-5.988 \\
(10.49)\end{array}$ & $\begin{array}{l}-0.889 \\
(10.30)\end{array}$ & $\begin{array}{c}0.143 \\
(11.40)\end{array}$ & $\begin{array}{c}4.544 \\
(11.46)\end{array}$ & $\begin{array}{l}-8.863 \\
(10.27)\end{array}$ & $\begin{array}{l}-4.061 \\
(10.09)\end{array}$ & $\begin{array}{l}-13.06 \\
(21.54)\end{array}$ & $\begin{array}{l}-6.990 \\
(21.26)\end{array}$ \\
\hline $\mathrm{HH}$ head education in years & $\begin{array}{c}1.159 \\
(0.832)\end{array}$ & $\begin{array}{l}1.567^{*} \\
(0.863)\end{array}$ & $\begin{array}{c}1.344 \\
(0.845)\end{array}$ & $\begin{array}{l}1.756 * * \\
(0.888)\end{array}$ & $\begin{array}{c}0.991 \\
(0.832)\end{array}$ & $\begin{array}{c}1.387 \\
(0.860)\end{array}$ & $\begin{array}{c}2.401 \\
(1.593)\end{array}$ & $\begin{array}{l}2.855^{*} \\
(1.630)\end{array}$ \\
\hline Number of $\mathrm{HH}$ assets per capita & $\begin{array}{l}-18.48 \\
(11.35)\end{array}$ & $\begin{array}{l}-13.65 \\
(10.99)\end{array}$ & $\begin{array}{l}-16.61 \\
(11.92)\end{array}$ & $\begin{array}{l}-10.66 \\
(11.50)\end{array}$ & $\begin{array}{l}-17.85 \\
(11.00)\end{array}$ & $\begin{array}{l}-13.02 \\
(10.59)\end{array}$ & $\begin{array}{c}4.822 \\
(23.00)\end{array}$ & $\begin{array}{c}9.152 \\
(22.62)\end{array}$ \\
\hline Other crop sales per capita & $\begin{array}{l}0.00487 \\
(0.0172)\end{array}$ & $\begin{array}{c}0.0111 \\
(0.0166)\end{array}$ & $\begin{array}{c}0.0177 \\
(0.0184)\end{array}$ & $\begin{array}{c}0.0265 \\
(0.0186)\end{array}$ & $\begin{array}{l}0.00878 \\
(0.0167)\end{array}$ & $\begin{array}{c}0.0150 \\
(0.0161)\end{array}$ & $\begin{array}{c}0.0500 \\
(0.0328)\end{array}$ & $\begin{array}{c}0.0538 \\
(0.0343)\end{array}$ \\
\hline Region fixed-effects & & Yes & & Yes & & Yes & & Yes \\
\hline Observations & 1,610 & 1,610 & 1,610 & 1,610 & 1,610 & 1,610 & 1,610 & 1,610 \\
\hline R-squared & 0.160 & 0.174 & 0.038 & 0.023 & 0.198 & 0.211 & 0.182 & 0.195 \\
\hline F-stat & & & 32.644 & 23.349 & & & 57.778 & 45.49 \\
\hline Kleibergen-Paap Wald F stat & & & 16.826 & 15.788 & & & 28.055 & 26.948 \\
\hline
\end{tabular}

Notes: Standard errors are clustered at the village level and reported in parentheses. $* * * \mathrm{p}<0.01, * * \mathrm{p}<0.05, * \mathrm{p}<0.1$ 
Table 3.7: Coffee profits per kg (UShs). Full Specification

\begin{tabular}{|c|c|c|c|c|c|c|c|c|}
\hline & \multicolumn{8}{|c|}{ Profits per kg (Ushs) } \\
\hline & $\begin{array}{l}\text { OLS } \\
\text { (1) }\end{array}$ & $\begin{array}{l}\text { OLS } \\
(2)\end{array}$ & $\begin{array}{c}\text { 2SLS } \\
\text { (3) }\end{array}$ & $\begin{array}{l}\text { 2SLS } \\
(4)\end{array}$ & $\begin{array}{l}\text { OLS } \\
\text { (5) }\end{array}$ & $\begin{array}{l}\text { OLS } \\
(6)\end{array}$ & $\begin{array}{c}\text { 2SLS } \\
(7)\end{array}$ & $\begin{array}{c}\text { 2SLS } \\
(8)\end{array}$ \\
\hline Sell parchment $(0 / 1)$ & $\begin{array}{c}-226.1^{* * *} \\
(15.92)\end{array}$ & $\begin{array}{c}-224.4^{* * * *} \\
(15.73)\end{array}$ & $\begin{array}{c}-307.2^{* * *} \\
(116.4)\end{array}$ & $\begin{array}{c}-296.8^{* *} \\
(150.2)\end{array}$ & & & & \\
\hline $\begin{array}{l}\text { Share of cherries processed } \\
\text { into parchment }(\%)\end{array}$ & & & & & $\begin{array}{l}-2.942^{* * * *} \\
(0.188)\end{array}$ & $\begin{array}{c}-2.922 * * * \\
(0.185)\end{array}$ & $\begin{array}{c}-2.825 * * * \\
(1.075)\end{array}$ & $\begin{array}{l}-2.599 * * \\
(1.321)\end{array}$ \\
\hline Coffee farm size in acres & $\begin{array}{c}9.706 \\
(6.136)\end{array}$ & $\begin{array}{c}6.224 \\
(6.225)\end{array}$ & $\begin{array}{c}15.28 \\
(9.605)\end{array}$ & $\begin{array}{c}10.88 \\
(10.86)\end{array}$ & $\begin{array}{c}7.690 \\
(6.048)\end{array}$ & $\begin{array}{c}4.295 \\
(6.106)\end{array}$ & $\begin{array}{c}7.155 \\
(7.243)\end{array}$ & $\begin{array}{c}2.916 \\
(7.596)\end{array}$ \\
\hline Experience with coffee farming & $\begin{array}{l}1.144 * * \\
(0.576)\end{array}$ & $\begin{array}{l}1.220 * * \\
(0.568)\end{array}$ & $\begin{array}{l}1.465 * * \\
(0.695)\end{array}$ & $\begin{array}{l}1.476 * \\
(0.768)\end{array}$ & $\begin{array}{l}1.015^{*} \\
(0.578)\end{array}$ & $\begin{array}{l}1.084^{*} \\
(0.570)\end{array}$ & $\begin{array}{c}0.984 \\
(0.624)\end{array}$ & $\begin{array}{c}1.012 \\
(0.647)\end{array}$ \\
\hline Altitude in meters & $\begin{array}{c}0.0180 \\
(0.0421)\end{array}$ & $\begin{array}{c}0.0487 \\
(0.0662)\end{array}$ & $\begin{array}{c}0.0115 \\
(0.0428)\end{array}$ & $\begin{array}{c}0.00544 \\
(0.107)\end{array}$ & $\begin{array}{c}0.0143 \\
(0.0423)\end{array}$ & $\begin{array}{c}0.0375 \\
(0.0668)\end{array}$ & $\begin{array}{c}0.0152 \\
(0.0419)\end{array}$ & $\begin{array}{r}0.0535 \\
(0.0899)\end{array}$ \\
\hline Pest and disease pressure (0-7) & $\begin{array}{l}-2.266 \\
(14.94)\end{array}$ & $\begin{array}{l}-25.43 \\
(17.47)\end{array}$ & $\begin{array}{c}3.827 \\
(17.37)\end{array}$ & $\begin{array}{l}-19.56 \\
(21.03)\end{array}$ & $\begin{array}{c}6.102 \\
(14.51)\end{array}$ & $\begin{array}{l}-16.24 \\
(16.88)\end{array}$ & $\begin{array}{c}5.100 \\
(16.94)\end{array}$ & $\begin{array}{l}-19.26 \\
(20.47)\end{array}$ \\
\hline Distance to buying centre & $\begin{array}{l}-0.646 \\
(0.905)\end{array}$ & $\begin{array}{l}-0.380 \\
(0.893)\end{array}$ & $\begin{array}{l}-0.945 \\
(0.911)\end{array}$ & $\begin{array}{l}-0.609 \\
(0.899)\end{array}$ & $\begin{array}{l}-0.676 \\
(0.876)\end{array}$ & $\begin{array}{l}-0.413 \\
(0.869)\end{array}$ & $\begin{array}{l}-0.642 \\
(0.880)\end{array}$ & $\begin{array}{c}-0.331 \\
(0.860)\end{array}$ \\
\hline $\mathrm{HH}$ size & $\begin{array}{c}5.512 \\
(3.394)\end{array}$ & $\begin{array}{l}6.558^{*} \\
(3.407)\end{array}$ & $\begin{array}{l}6.916^{*} \\
(3.858)\end{array}$ & $\begin{array}{l}7.678 * \\
(4.053)\end{array}$ & $\begin{array}{c}4.026 \\
(3.430)\end{array}$ & $\begin{array}{c}5.026 \\
(3.444)\end{array}$ & $\begin{array}{c}3.930 \\
(3.501)\end{array}$ & $\begin{array}{c}4.812 \\
(3.531)\end{array}$ \\
\hline Female household head $(0 / 1)$ & $\begin{array}{l}-7.411 \\
(22.25)\end{array}$ & $\begin{array}{l}-0.913 \\
(21.98)\end{array}$ & $\begin{array}{l}-3.276 \\
(22.70)\end{array}$ & $\begin{array}{c}1.998 \\
(22.39)\end{array}$ & $\begin{array}{l}-12.81 \\
(21.75)\end{array}$ & $\begin{array}{l}-6.625 \\
(21.53)\end{array}$ & $\begin{array}{l}-13.06 \\
(21.54)\end{array}$ & $\begin{array}{l}-6.990 \\
(21.26)\end{array}$ \\
\hline $\mathrm{HH}$ head education in years & $\begin{array}{l}2.702^{*} \\
(1.603)\end{array}$ & $\begin{array}{l}3.169^{*} \\
(1.642)\end{array}$ & $\begin{array}{l}2.827^{*} \\
(1.572)\end{array}$ & $\begin{array}{l}3.270 * * \\
(1.622)\end{array}$ & $\begin{array}{c}2.403 \\
(1.600)\end{array}$ & $\begin{array}{l}2.855^{*} \\
(1.633)\end{array}$ & $\begin{array}{c}2.401 \\
(1.593)\end{array}$ & $\begin{array}{l}2.855^{*} \\
(1.630)\end{array}$ \\
\hline Number of $\mathrm{HH}$ assets per capita & $\begin{array}{c}4.117 \\
(23.73)\end{array}$ & $\begin{array}{c}8.994 \\
(23.17)\end{array}$ & $\begin{array}{c}5.380 \\
(23.81)\end{array}$ & $\begin{array}{c}10.59 \\
(23.29)\end{array}$ & $\begin{array}{c}4.996 \\
(23.03)\end{array}$ & $\begin{array}{c}9.788 \\
(22.48)\end{array}$ & $\begin{array}{c}4.822 \\
(23.00)\end{array}$ & $\begin{array}{c}9.152 \\
(22.62)\end{array}$ \\
\hline Other crop sales per capita & $\begin{array}{c}0.0458 \\
(0.0304)\end{array}$ & $\begin{array}{l}0.0520 * \\
(0.0309)\end{array}$ & $\begin{array}{c}0.0544 \\
(0.0353)\end{array}$ & $\begin{array}{c}0.0602 \\
(0.0377)\end{array}$ & $\begin{array}{l}0.0511^{*} \\
(0.0305)\end{array}$ & $\begin{array}{l}0.0572 * \\
(0.0310)\end{array}$ & $\begin{array}{c}0.0500 \\
(0.0328)\end{array}$ & $\begin{array}{c}0.0538 \\
(0.0343)\end{array}$ \\
\hline Region fixed-effects & & Yes & & Yes & & Yes & & Yes \\
\hline Observations & 1,610 & 1,610 & 1,610 & 1,610 & 1,610 & 1,610 & 1,610 & 1,610 \\
\hline R-squared & 0.124 & 0.129 & 0.109 & 0.117 & 0.142 & 0.146 & 0.141 & 0.145 \\
\hline F-stat & & & 32.644 & 23.349 & & & 57.778 & 45.49 \\
\hline Kleibergen-Paap Wald F stat & & & 16.826 & 15.788 & & & 28.055 & 26.948 \\
\hline
\end{tabular}

Notes: Standard errors are clustered at the village level and reported in parentheses. *** $\mathrm{p}<0.01, * * \mathrm{p}<0.05, * \mathrm{p}<0.1$ 
Table 3.8: Descriptive Statistics

\begin{tabular}{lcccccc}
\hline \hline & \multicolumn{2}{c}{ HH produces } & \multicolumn{2}{c}{ HH produces only } & & \\
& parchment $(\mathrm{N}=655)$ & cherries $(\mathrm{N}=955)$ & Mean & St. \\
& Mean & St dev & Mean & St dev & Difference & error \\
\hline Revenues per kg (Ushs) & 1049 & 112 & 1225 & 173 & $122^{* * * *}$ & 7.691 \\
Profits per kg (Ushs) & 740.2 & 273.9 & 1038.9 & 295.7 & $213^{* * *}$ & 14.892 \\
Coffee harvest in kg & 1550 & 1893 & 535 & 676 & $-859^{* * *}$ & 60.174 \\
Coffee farm size in acres & 1.6 & 1.2 & 1.3 & 0.9 & $-0.455^{* * *}$ & 0.059 \\
Experience with coffee farming & 27.3 & 15.2 & 25.2 & 14.1 & $-2.629^{* * *}$ & 0.721 \\
Altitude in metres & 1737 & 188 & 1782 & 231 & 18 & 11.897 \\
Pest and disease pressure (0-7) & 1.2 & 0.5 & 1.0 & 0.5 & -0.034 & 0.065 \\
Number of HH with pulpers & 1.6 & 1.5 & 1.1 & 1.2 & $-0.471^{* * *}$ & 0.068 \\
Quality knowledge score (0-10) & 5.0 & 1.7 & 4.7 & 1.8 & $-0.491^{* * * *}$ & 0.092 \\
Knowledge parchment (0/1) & 0.5 & 0.5 & 0.5 & 0.5 & $0.093^{* * *}$ & 0.025 \\
Cognitive ability score (0-10) & 3.9 & 2.3 & 4.0 & 2.3 & -0.1 & 0.116 \\
Distance to buying centre in km & 14.6 & 5.0 & 15.9 & 8.7 & $1.411^{* * * *}$ & 0.418 \\
HH size & 6.3 & 2.2 & 6.2 & 2.5 & $-0.367^{* * * *}$ & 0.123 \\
Female household head (0/1) & 0.1 & 0.3 & 0.1 & 0.3 & 0.0 & 0.018 \\
HH head age in years & 53.4 & 13.6 & 51.8 & 13.6 & $-1.18^{* *}$ & 0.687 \\
HH head education in years & 8.8 & 5.5 & 8.8 & 5.6 & -0.3 & 0.282 \\
Number of HH assets per capita & 0.5 & 0.4 & 0.4 & 0.4 & $-0.035^{* *}$ & 0.019 \\
Crop sales per capita (000 UShs) & 237.5 & 312.0 & 176.3 & 324.0 & $-42.50^{* * *}$ & 15.93 \\
\hline \hline
\end{tabular}

Table 3.9: First stage of IV estimations

\begin{tabular}{lcccc}
\hline \hline & \multicolumn{2}{l}{ Produce any parchment } & \multicolumn{2}{l}{$\begin{array}{l}\text { Share of cherries } \\
\text { processed into parchment (\%) }\end{array}$} \\
\hline & $(1)$ & $(2)$ & $(3)$ & $(4)$ \\
\hline $\begin{array}{l}\text { Number of farmers who own } \\
\text { pulpers in the group }\end{array}$ & $0.0512^{* \cdots * *}$ & $0.0433^{* * * *}$ & $5.565^{* * *}$ & $4.943^{* * *}$ \\
& $(0.0125)$ & $(0.0109)$ & $(1.051)$ & $(0.952)$ \\
& & & & \\
HH and farm controls & Yes & Yes & Yes & Yes \\
Region fixed-effects & & Yes & & Yes \\
F-stat & 32.644 & 23.349 & 57.778 & 45.49 \\
Kleibergen-Paap Wald F statistic & 16.826 & 15.788 & 28.055 & 26.948 \\
Observations & 1610 & 1610 & 1610 & 1610 \\
\hline \hline
\end{tabular}

Table 3.10: Stated reasons for parchment production

\begin{tabular}{lcc}
\hline \hline Stated reasons for parchment production & Freq. & Percent \\
\hline (1) It is what I have always done & 61 & 9.31 \\
(2) I produce parchment only using lower quality cherries & 56 & 8.55 \\
(3) I prefer to receive (lumpsum) money at once & 216 & 32.98 \\
(4) I make more money from parchment & 307 & 46.87 \\
(5) Other & 15 & 2.29 \\
Total & 655 & 100 \\
\hline \hline
\end{tabular}


Table 3.11: Stated reasons for parchment production. Marginal effects. Probit estimations

\begin{tabular}{lcccc}
\hline \hline & $\begin{array}{c}\text { Have always } \\
\text { done parchment } \\
(0 / 1)\end{array}$ & $\begin{array}{c}\text { Only low } \\
\text { quality } \\
\text { cherries }(0 / 1)\end{array}$ & $\begin{array}{c}\text { Prefer } \\
\text { lumpsum } \\
(0 / 1)\end{array}$ & $\begin{array}{c}\text { Make } \\
\text { more money } \\
(0 / 1)\end{array}$ \\
\hline & $(1)$ & $(2)$ & $(3)$ & $(4)$ \\
\hline Quality knowledge score (0-10) & $-0.0207^{* * *}$ & $0.0285^{* * *}$ & 0.0007 & -0.0136 \\
& $(0.0076)$ & $(0.0072)$ & $(0.0100)$ & $(0.0121)$ \\
Parchment knowledge (0/1) & -0.0292 & -0.0244 & 0.0281 & 0.0346 \\
& $(0.0236)$ & $(0.0184)$ & $(0.0339)$ & $(0.0394)$ \\
Cognitive ability score (0-10) & $0.0116^{* *}$ & $0.0134^{* * *}$ & $-0.0314^{* * *}$ & -0.0038 \\
Distance to buying centre in km & $(0.0053)$ & $(0.0043)$ & $(0.00926)$ & $(0.0091)$ \\
& -0.0021 & -0.00245 & 0.00105 & 0.0018 \\
Coffee harvest in kg & $(0.0016)$ & $(0.0016)$ & $(0.0022)$ & $(0.0023)$ \\
& -0.0001 & -0.0000 & $0.00003^{* * * *}$ & $-0.00003 * *$ \\
Altitude in meters & $(0.0001)$ & $(0.0000)$ & $(0.00001)$ & $(0.0000)$ \\
Pest and disease pressure (0-7) & -0.00001 & 0.00004 & 0.00001 & 0.00002 \\
& $(0.00001)$ & $(0.0001)$ & $(0.00001)$ & $(0.00001)$ \\
Hire labour (0/1) & 0.0130 & $-0.0886^{* * *}$ & 0.0192 & 0.0666 \\
& $(0.0269)$ & $(0.0305)$ & $(0.0404)$ & $(0.0412)$ \\
Experience with coffee farming & 0.0311 & -0.00443 & 0.0246 & -0.0438 \\
& $(0.0225)$ & $(0.0231)$ & $(0.0379)$ & $(0.0420)$ \\
HH size & $0.0024^{* * *}$ & $0.0013^{*}$ & 0.0016 & $-0.00605^{* * *}$ \\
& $(0.0008)$ & $(0.0006)$ & $(0.0013)$ & $(0.0014)$ \\
Crop sales per capita & $-0.0075^{* * *}$ & $0.00829^{* *}$ & 0.00917 & -0.0130 \\
& $(0.0038)$ & $(0.0048)$ & $(0.0081)$ & $(0.00822)$ \\
Observations & 0.00003 & $-0.0001^{* * *}$ & -0.0001 & 0.0001 \\
\hline \hline & $(0.00003)$ & $(0.0001)$ & $(0.0001)$ & $(0.0001)$ \\
& & & & 655 \\
\hline
\end{tabular}

Notes: Standard errors are clustered at the village level and reported in parentheses. $* * * \mathrm{p}<0.01$, $* * \mathrm{p}<0.05, * \mathrm{p}<0.1$ 
Table 3.12: Second-stage coefficients estimated with different models

\begin{tabular}{|c|c|c|c|c|}
\hline & \multicolumn{4}{|c|}{ Share of cherries processed into parchment (\%) } \\
\hline & $\begin{array}{l}\text { Truncated } \\
\text { normal } \\
(1)\end{array}$ & $\begin{array}{l}\text { Double-bounded } \\
\text { truncated normal } \\
\text { (2) }\end{array}$ & $\begin{array}{c}\text { Truncated } \\
\text { lognormal } \\
\text { (3) }\end{array}$ & $\begin{array}{c}\text { Exponential } \\
\text { Type II Tobit } \\
\text { (4) }\end{array}$ \\
\hline Quality knowledge (0-10) & $\begin{array}{c}-1.494^{* * *} \\
(0.511)\end{array}$ & $\begin{array}{l}-1.683 * \\
(0.881)\end{array}$ & $\begin{array}{c}-0.0075 * * * \\
(0.0025)\end{array}$ & $\begin{array}{c}-0.0305 * * \\
(0.0129)\end{array}$ \\
\hline Parchment knowledge $(0 / 1)$ & $\begin{array}{c}1.261 \\
(1.887)\end{array}$ & $\begin{array}{l}-2.332 \\
(3.392)\end{array}$ & $\begin{array}{c}0.0016 \\
(0.0093)\end{array}$ & $\begin{array}{l}-0.0170 \\
(0.0460)\end{array}$ \\
\hline Cognitive ability (0-10) & $\begin{array}{c}-1.119 * * * \\
(0.429)\end{array}$ & $\begin{array}{c}-1.909 * * \\
(0.765)\end{array}$ & $\begin{array}{c}-0.0052 * * \\
(0.0021)\end{array}$ & $\begin{array}{l}-0.0207 * * \\
(0.0099)\end{array}$ \\
\hline Distance to buying centre & $\begin{array}{l}-0.0860 \\
(0.123)\end{array}$ & $\begin{array}{l}-0.173 \\
(0.195)\end{array}$ & $\begin{array}{l}-0.0006 \\
(0.0007)\end{array}$ & $\begin{array}{l}-0.0021 \\
(0.0026)\end{array}$ \\
\hline Coffee harvest in $\mathrm{kg}$ & $\begin{array}{c}0.0018 * * * \\
(0.0006)\end{array}$ & $\begin{array}{l}0.0030 * * \\
(0.00125)\end{array}$ & $\begin{array}{l}0.0003 * * \\
(0.00002)\end{array}$ & $\begin{array}{c}0.0001 \\
(0.0002)\end{array}$ \\
\hline Altitude in metres & $\begin{array}{c}-0.0132 * * * \\
(0.0045)\end{array}$ & $\begin{array}{l}-0.0093 \\
(0.0079)\end{array}$ & $\begin{array}{l}0.00003 * \\
(0.0000)\end{array}$ & $\begin{array}{l}0.00003 \\
(0.0001)\end{array}$ \\
\hline Pest and disease pressure (0-7) & $\begin{array}{c}6.882 * * * \\
(1.977)\end{array}$ & $\begin{array}{l}6.509^{*} \\
(3.667)\end{array}$ & $\begin{array}{c}0.0358 * * * \\
(0.0098)\end{array}$ & $\begin{array}{c}0.0775 \\
(0.0501)\end{array}$ \\
\hline $\mathrm{HH}$ size & $\begin{array}{c}-1.304 * * * * \\
(0.392)\end{array}$ & $\begin{array}{c}-1.909 * * * \\
(0.701)\end{array}$ & $\begin{array}{c}-0.0075 * * * \\
(0.0019)\end{array}$ & $\begin{array}{c}-0.0325 * * * \\
(0.0094)\end{array}$ \\
\hline Sigma-lnsigma & $\begin{array}{c}23.42^{* * *} \\
(0.664)\end{array}$ & $\begin{array}{l}3.293 * * * \\
(0.0651)\end{array}$ & $\begin{array}{l}-2.154 * * * \\
(0.0276)\end{array}$ & \\
\hline IMR & & & & $\begin{array}{c}-0.152 \\
(0.133)\end{array}$ \\
\hline Log (pseudo)likelihood & -3930.368 & -3310.055 & -798.527 & \\
\hline Wald chi2 & $233.12 * * *$ & & $353.96 * * *$ & \\
\hline Observations & 1,610 & 1,610 & 1,610 & 1,610 \\
\hline
\end{tabular}

Notes: Due to computational difficulties we had to restrict the covariate set to variables more likely to explain the variation in parchment production. Standard errors are reported in parentheses. ${ }^{* * *} \mathrm{p}<0.01,{ }^{* *} \mathrm{p}<0.05,{ }^{*} \mathrm{p}<0.1$ 


\section{Chapter 4}

\section{Inefficiency in the household: a gendered analysis of willingness to pay to hide income from spouses in ru- ral Uganda}

We present a study that focuses on efficiency of household decision making using data from 422 households in the highlands of Uganda. Employing an established revealed preference approach, the Becker-DeGroot-Marschak (BDM) mechanism, we elicit the willingness to pay of women and men to receive the experimental reward in private (secret from their spouse) instead of publicly (in front of their spouse). Our results show that efficiency losses arising from willingness to hide income are on average half of the potential gains from the experiment, but do not significantly differ across genders. Additionally, we document a negative and significant relationship between willingness to hide income and equality in say in household decisions between partners (women's empowerment), aggression in the household, and membership in savings groups. Exploiting the random assignment of reward either privately or publicly, generated by the BDM mechanism, we find evidence that men take advantage of the information asymmetries within the household to alter allocations of household resources towards private consumption whereas women tend to hide money to avoid claims over it by their husband. Our results have considerable public policy relevance regarding interventions, such as social protection, financial inclusion, and value chain development activities, powerful tools to lift people out of poverty.

Keywords: gender; empowerment; intra-household; efficiency; asymmetric information; income hiding; BDM mechanism

JEL Codes: O12, D13, J12, D82

This chapter is a joint work with Daniel Gregg and Alexandra Peralta. I designed the research, collected and analysed the data, and wrote the manuscript. Daniel Gregg contributed to research design, provided significant feedback at various stages of the research and edited the manuscript. Alexandra Peralta provided feedback at various stages. 


\subsection{Introduction}

The inner workings of households remain a key factor affecting the effectiveness of public policies and development interventions (Fiszbein and Schady, 2009). Of particular concern for such interventions is how the household resources are allocated. These concerns arise particularly in the context of differing preferences and non-cooperation between the male and female household heads. In noncooperative household models, differences in preferences between household members guide household choice in ways that are not necessarily in the spirit of household welfare maximisation but for individual gain. While this view of household behaviour is irreconcilable with the early household models, such as the common preference and collective models (Samuelson, 1956; Becker, 1974; Chiappori, 1992), there is increasing evidence that these 'noncooperative' models are more relevant for informing policy since they provide insights into dynamics of household decision making, for instance, how household income can be eroded through hidden consumption by the recipients(Ashraf et al., 2009; Castilla and Walker, 2013).

A key element in the noncooperative household model is the (dis)incentives for household members to behave in ways against the objectives of household welfare maximisation, such as punishment. Asymmetric information between spouses precludes punishment for actions against household expectations and allow individuals to exploit the lack of knowledge of their partner, for instance, regarding the household income. Castilla and Walker (2012) demonstrate that there will be incentives for income-hiding when preferences between spouses differ in presence of specific gender roles and under asymmetric information. Empirical evidence for income hiding under asymmetric information has been forthcoming with Chen (2006) who documents noncooperative behaviour regarding spending of remittance income received from migrant husbands, which leads to an increase in the nutritional intake of children. Ashraf et al. (2014) show that women are more likely to use contraceptives when they are given access to contraceptives alone than with their partner (because contraceptive use cannot be perfectly observed by men). Ashraf et al. (2009) also provide evidence for income hiding in a savings experiment in the Philippines wherein men are more likely to deposit the endowment into their spouse's account when the endowment is known by their spouse whereas more likely to deposit it in their private accounts when choices are private.

These studies point out the possibility that asymmetric information can be used 
to the advantage of household welfare when that information is held by the female spouse. Indeed, in several cases, cash transfer programs provide income to female household heads based on the assumption and findings that women spend more of their income on consumption that supports household welfare overall, compared to men who tend to spend more on expenditures that support individual welfare (Hoddinott and Haddad, 1995; Duflo, 2003; Gertler, 2004; De Janvry and Sadoulet, 2006; Robinson, 2012). Even though official transfers are known by household members, they may nonetheless loosen constraints over other income sources that are not easily observed.

This study draws upon several key issues in household behaviour literature, such as efficiency, decision-making dynamics, income hiding, and preferences for allocation of household resources to private and public goods. In particular, we elicit willingness to pay of either female or male household head to receive an endowment private from their partner versus the alternative of in front of their partner. Positive willingness to pay to keep money private implies efficiency losses since the participant is willing to sacrifice household income for greater control over that income. In addition to testing household efficiency and quantifying the efficiency losses arising from income hiding, this study answers the following questions: (i) Is one gender more willing to hide income than the other? (ii) Does willingness to hide income diminish in the size of windfall income? (iii) Does (equality of) input in household decisions explain willingness to pay to hide income? (iv) Do household members exploit information advantages over their spouse to alter allocations of resources to public (household) and private goods?

This study tests whether households make efficient decisions regarding the receipt of income using an established, but novel in this context, revealed preference approach, the Becker-De Groot-Marshak (BDM) mechanism (Becker et al., 1964). The BDM mechanism provides a robust estimate of the willingness to pay (WTP) of a spouse to keep an endowment private and provides both a test of the efficiency hypothesis $(\mathrm{WTP}=0$ ) and a measure of the extent of efficiency losses based on the level of WTP greater than zero. The BDM mechanism involves a random price draw feature which generates a random allocation, with known probability, of endowments as private versus public for a given level of WTP. We then compare spending patterns of respondents who were allocated to receiving their income privately or publicly. Whilst being limited to those stating WTP values of $0<$ WTP $<1$ (those stating minimum and maximum value always receive their endowment publicly and privately, respectively), it nevertheless provides an exo- 
geneity device, conditional on stated WTP, for allocation of income that is unique in this literature.

Results indicate a substantial variation in the stated WTP to keep income private from spouse. In particular, 99 percent of the households are willing to pay a positive amount to keep the money private and efficiency losses amount to, on average, 50 percent of the experimental reward otherwise received publicly. Women tend to state slightly higher WTP but the difference between women and men is not statistically different from zero. We find that equality in say in household decisions, women's empowerment and membership in savings groups are negatively associated with WTP to hide income. Using the BDM mechanism's quasi-random allocation of rewards either publicly or privately we find that men who receive the money in private are more likely to have the intention to spend the reward on private expenses and less likely to intend to spend the reward for the household. Additionally, weekly private spending (relative to household spending) goes up for those who received the reward in private in the week following the experiment. Our findings indicate that household behaviour in our sample is not efficient as postulated by the unitary and collective models but consistent with noncooperative decision making wherein individuals may have an incentive to conceal income to maximise their own utility.

This study contributes to the household behaviour literature in four key ways. Firstly, we document Pareto inefficient household outcomes and provide evidence against the unitary and cooperative household models employing an established revealed preference approach, BDM mechanism. The use of the BDM mechanism is novel in testing efficiency in this strand of literature. One exception is Almas et al. (2018) that uses BDM mechanism to elicit WTP of women to be the recipient of a cash transfer otherwise offered to their husband in urban Macedonia. We elicit WTP of both women and men to hide a cash windfall from their spouse in rural Uganda. Relatedly, Jakiela and Ozier (2016) and Boltz et al. (2019) also elicit WTP to hide income of Senegalese households but from kin outside the household to document redistributive social pressure. Secondly, we document differing drivers of willingness to hide income across genders. Almas et al. (2018) demonstrate that the WTP of women can be considered an alternative measure of power in the household. Consistent with this finding, we show that WTP to keep money private is negatively associated with equality in input given into household decisions further validating the approach, which is easy to implement outside the lab in rural areas, for studying household decision making dynamics. Thirdly, we 
document a positive relationship between household efficiency and membership in savings group, which is largely undocumented in the literature, suggesting a role for financial inclusion interventions. Lastly, making use of the randomisation generated by the BDM mechanism in allocation of the experimental reward either privately or publicly, we analyse the role of asymmetric information between partners regarding resources on expenditure choices. Ashraf (2009) tests the role of asymmetric information in allocation of endowments to private or household accounts in the Philippines but do not analyse the behaviour (actual spending) outside the lab. Few studies analyse the effect of asymmetric information between spouses on actual spending behaviour. This study is most similar to that of Castilla and Walker (2013) who analyse the spending of men and women who were randomly assigned to receiving a public or private prize in Ghana. The randomisation generated within the BDM mechanism, however, is unique in the literature in causal analysis of the role of information asymmetry between spouses regarding resources in consumption preferences.

This paper is organised as follows. The next section reviews the theory and evidence on household behaviour. Section 3 describes the experimental method and procedures. Section 4 presents the data and descriptive statistics. Section 5 focuses on the empirical strategy. Section 6 presents and discusses the results. Last section concludes.

\subsection{Review of theories and evidence on household behaviour}

The conceptualization of decision making within the household is a contested area of economic theory. Early theoretical models, such as the common preference or unitary-type models (Samuelson, 1956; Becker, 1974) focus on household level choices. These unitary models assume that individuals' preferences in the household can be adequately represented by a single household-level utility function. This implies either that household members have similar preferences (Samuelson's consensus model) or that one household member makes the decisions for everyone (Becker's altruist dictator). These unitary-type models employ a social welfare (household utility) function that is an increasing function of the utilities of all household members which ensures Pareto efficiency in that no member can be made better off without making another worse off through transfer of income between household members. Household behaviour does not depend on the individual incomes of members but rather on total household income (i.e. income 
pooling). As a result, the unitary-type models provide little insight into intrahousehold dynamics, an aspect that is increasingly of interest for development interventions and policies, such as social protection programs.

In response to the increasing interest in the dynamics of household decision making, alternative models have been developed that focus on the bargaining dynamics between male and female spouses in the household (Manser and Brown, 1980; McElroy and Horney, 1981; Chiappori, 1992; Browning and Chiappori, 1998). These cooperative/collective models allow for explicitly identifying individuals as having different preferences and utility functions and also for the representation of household choices arising from bargaining in the household. The collective approach characterises the equilibrium distribution by a set of axioms, one of which is efficiency (Browning et al., 2014). Efficiency does not preclude the existence of power issues within the household, however. On the contrary, under cooperative models, spousal bargaining power is explicitly represented within the household utility function. These models allow for occurrence of conflicts regarding distribution of resources but stipulate that they are resolved, for example, by bargaining, contracts, social norms or through feelings of members towards each other. Importantly, for the purposes of testing the validity of the collective model, Pareto efficiency postulates that, however resources are allocated between the members, none is ultimately left on the table (Browning et al., 2014). Thus, this model incorporates a testable efficiency hypothesis in that the household cannot be made better off by redistributing income from one spouse to another.

Empirical research testing the efficiency assumption of the cooperative model using observational data on households has yielded mixed results. Providing support for the assumption, Quisumbing and Maluccio (2003) document expenditure patterns consistent with the cooperative model in Bangladesh, Indonesia, Ethiopia, and South Africa. Similarly, Rangel and Thomas (2005) find evidence that heterogeneity of preferences within farm households does not preclude an efficient allocation of family resources in West Africa. Bobonis (2009) finds that changes in female income positively affect spending on children whereas negative changes due to rainfall shocks have a smaller influence on household expenses indicating Pareto optimality. However, many other studies have found the efficiency assumption questionable. Early work, such as that of Udry (1996) finds that fertiliser and labour are not efficiently allocated across plots owned by men and women in Burkina Faso. Similarly, McPeak and Doss (2006) find that location decisions (by males) and milk marketing decisions (by females) within pastoralist households 
in Northern Kenya lead to inefficient household welfare outcomes. Whilst providing a basis on which to consider the validity of the efficiency assumption, studies based on survey data are limited by the need to make restrictive assumptions to identify inefficient outcomes and potentially fail to adequately address selection bias.

In contrast, direct approaches to examining inefficiency typically employ experimental methods, such as public good and trust games, in which participants are offered options with different payoffs. In all cases, there is an option that maximises household payoff and efficiency is rejected when household members do not choose the option that maximises household payoffs. For instance, Castilla (2015) finds that only 3 percent of the couples in an experiment in India choose the payoff-maximizing strategy. Iversen et al. (2011) in Uganda, Munro et al. (2014) and Mani (2020) in India, and Kebede et al. (2014) in Ethiopia, and Hoel (2015) in Kenya using similar games report large efficiency losses. Fiala and $\mathrm{He}$ (2017) conclude that there is no "one-size-fits-all" household model because there are many payoff-maximizing households in addition to many couples that forgo overall efficiency. Note, however, that participation of both spouses in these experiments likely confounds the decisions made in the experiment since partners have priors over decisions and payoffs. It is difficult to account for the bias introduced by the scrutiny effects and potential post-experimental consequences and compensations as a result of the decisions in the experiment (Munro, 2018).

In response to the potential for inefficient outcomes arising from incomplete bargaining and information sharing between household members, alternative approaches to bargaining that consider incomplete cooperation have emerged (Ulph, 1988; Chen and Woolley, 2001). These noncooperative models, explicitly allow for outcomes where potential gains from cooperation are not necessarily realised (i.e. Pareto inefficient) and where unresolved differences in preferences guide the dynamics of household choice (Browning et al., 2014). The potential for inefficiency in noncooperative models is more pronounced in presence of public goods and members can choose between directing resources toward private goods or to household (public) goods. In such cases suboptimal investment in household goods may emerge when disincentives are inexistent or ineffective in changing contributions toward those goods. This is the classical problem of under-provision of public goods in noncooperative models. Hence, a key element of the noncooperative model is the potential for asymmetric information to allow avoidance of sanctions that may otherwise induce efficient behaviour. 
Castilla and Walker (2012) formally demonstrate that there are incentives to hide income when preferences differ between the spouses, when there is asymmetric information over monetary transfers between spouses, and strictly positive transfers occur between spouses (e.g. men regularly provide women with money for household needs). This hypothesis is tested in a field experiment in which households are assigned to receive public or private cash prizes. They show that men allocate privately received cash transfers to alcohol consumption and gifts to his social network, while the women lend the money out to make it difficult for the husband to find it out or access it. Noncooperative household members with differing preferences may thus have the incentives to exploit asymmetric information to alter household allocations, for instance, from observable public goods (householdfocused, essential) to less easily monitored private goods. Income hiding might result in underinvestment of observable household goods undermining the effectiveness of development programs aimed at improving household welfare. The noncooperative model provides a conceptual pathway for improved effectiveness of development interventions, such as income transfers, financial inclusion and value chain development activities.

\subsection{Experimental Method and Procedures}

\subsubsection{The Becker-DeGroot-Marschak (BDM) mechanism}

The efficiency hypothesis embodied within the collective model (Chiappori, 1992) implies that no spouse would forgo resources to have greater control over that money. In this study the BDM mechanism is used to assess the willingness to pay (WTP) of participants to receive the experimental reward in private rather than in front of their spouse. The WTP statement provides both a robust test of the efficiency principle (WTP $=0$ ) and a quantification of the extent of inefficiency associated with non-cooperative household bargaining outcomes for cases where the WTP $>0$. Under the BDM WTP statements are elicited from participants for the receipt of money in private, as opposed to in public (in front of their partner). These statements can be interpreted as revealed preference WTP statements due to the implementation of a randomly drawn price that acts as a random selection mechanism for success (i.e. to receive money in private) for the demand (WTP) stated by the participant (Becker et al., 1964).

The BDM operates as a single-bid auction mechanism with a randomly selected price that determines success (WTP is higher than the price) or failure (WTP is 
lower than the price). In the BDM experiments participants are asked to state a maximum amount they are willing to pay to purchase a product (in this case to receive the experimental reward in private). A price is then randomly drawn from a distribution of prices chosen to cover the range of anticipated bids. If the stated WTP value is greater than or equal to the randomly drawn price, the participant is successful i.e. receives the reward in private minus the randomly drawn price. Else, the WTP value is less than the randomly drawn value and the participant fails i.e. receives the full reward amount but in front of his/her partner.

The BDM mechanism is incentive-compatible in that the respondents can achieve the best outcome by acting according to their true preferences because the stated WTP represents the maximum amount the respondent would have to pay to receive the reward private. If a respondent states less than their true WTP, there is a chance that the price drawn will fall between their stated value and their true WTP - meaning they would be unsuccessful in receiving income in private, despite being willing to pay the randomly selected price for that outcome. On the other hand, if they state a higher WTP than they would truly pay, the randomly selected price may again fall between the stated and true WTP value meaning that the respondent would purchase the private windfall, but at a cost they were not truly willing to pay. Thus, the random price mechanism of the BDM generates incentive compatibility for recipients to reveal their true WTP.

The BDM mechanism also provides a quasi-random selection mechanism into different treatment groups (private versus public income recipients) through the operation of the randomised price mechanism. The random market price mechanism of the BDM means that for non-boundary WTP statements, or cases where the WTP is higher than 0 and lower than 100 percent of the full reward offered $(0<$ WTP $<1)$, the receipt of income privately or known by partner depends both on the WTP statement and on the random price draw. We use this random draw feature to generate a random allocation, with known probability, of the experimental reward either secret from or known by participant's partner. This random allocation, conditional on stated WTP, allows direct comparison of expenditures on private versus household goods for respondents stating similar WTP values but allocated randomly to receiving their income privately or publicly. Thus, determination of the treatment group at random, through the BDM mechanism, provides an exogeneity device that allows us to make causal inferences over the role of asymmetric information about resources between spouses on actual spending patterns of participants in this study. 


\subsubsection{Experimental design and procedures}

In order to minimise scrutiny effects (Munro, 2018) only one spouse in each household was selected to participate in the study. This effect increases when both couples take part in experiments since they have priors over each other's options and potential payoffs. Interviewing one spouse alone was critical to give participants adequate anonymity in stating their WTP and ensure that the private rewards remained private to the extent possible. To minimise post-experimental information spill-overs through partners and neighbours regarding the rewards, we interviewed a couple of households (1-5) per village.

Gender of the participants was determined through a random selection process implemented prior to the household visit. The BDM mechanism was conducted with either the male or female primary decision maker in the (de-facto) married households and the selected participant was interviewed alone. Full rewards offered in the experiment were either 15,000 or 30,000 Ushs ( $\sim 4$ or 8 USD), worth approximately 2-5-day's labour wages. There is thus a large amount at stake, a factor that encourages thoughtful consideration of responses in field experiments. ${ }^{1}$ Two different rewards were offered to test whether WTP is decreasing in the amount offered.

The participants in the BDM mechanism were informed that they would receive a reward (R) as a lump-sum payment at the end of the task they were to undertake that day, and that they would have the opportunity to receive the reward in private or in front of their spouse (in public). The participants were told that the reward may be reduced if they wished to keep the reward private. They were then asked to state what it is worth for them to receive the money privately versus in front of their spouse. In particular, they were asked, out of the full reward amount (R) how much they are willing to lose in order to keep the reward itself secret. They were then asked to draw a random amount (V) from a bag in which there were numbers ranging between 1000 and $\mathrm{R}$ in 1,000 UShs increments. There were two possible outcomes: 1) If stated WTP was lower than the randomly drawn value, the full reward (R) was given to the participant in front of their partner at the end of the interview. 2) If stated WTP was greater than or equal to the randomly drawn value $(V)$, the participant received a value of $R-V$ and in private. Due to relative complexity of the BDM mechanism, in addition to thorough explanation

\footnotetext{
${ }^{1}$ As an example, Fiala and He (2017) offer 2,000 Ushs to participants in similar settings in Uganda.
} 
of the procedure, at least two practice rounds were undertaken to ensure complete understanding of the procedure by the respondent. Field assistants were instructed to run the practice round several times until the respondent gave the right answer in practice rounds. Instructions for the experiment are provided in Appendix C.

After completion of the experiment, participants were asked to answer a short questionnaire on socio-demographic characteristics and how they intend to spend the reward they earned. 5 to 7 days after the experiment, participants were visited again to answer another short questionnaire on their spending across different consumption categories in the past 7 days.

We made an appointment with the households two days before the experiment to ensure both partners were in principle available for the experiment. On the day of the experiment we only interviewed households where both partners were at least within the village at the time of the experiment. If the partner of the participant was not at homestead we reached him/her through telephone before we started the interview to make sure that the partner would be in the village. If the partner of the participant was not reached through phone or not in the position to be at homestead in a short amount of time, the interview did not take place. This was done to make sure that the partner was available in case the participant ended up receiving the money in front of their partner. The reward then would be presented to the participant in front of his/her partner with an explanation that the reward was given based on participant's answers to the questions asked in the survey.

It was also critical to ensure that the participants' responses and the following payment were completely anonymous to their spouse. This meant that the respondents were interviewed in a separate area where partners could not see or hear each other and with no other adults or older children present (i.e. only infants or very young children for example). The partner of the participant was told that we would ask some questions to their partner about how they made decisions regarding their household, that it was important to interview the respondent alone, and that we randomly selected either male of female decision maker in the household. It was also unlikely that household members (in particular the partner of the respondent) were in expectation of monetary benefits of any sort because of the visits. The households who participated in this study were visited and interviewed without monetary compensation 3 times in the past 3 years within the framework of other projects. 


\subsection{Data and Descriptive Statistics}

\subsubsection{Data}

Our sample consists of 422 households randomly drawn from a list of approximately 1600 coffee-growing households studied within the context of another project in the district of Kapchorwa in eastern Uganda. This larger sample of households was also randomly selected to be representative of coffee farming households in this region. The experiment for this study was undertaken in November 2019.

To minimise post-experimental effects (e.g. spouses providing post-experimental compensations to each other) and information spillovers through neighbours regarding the rewards, we interviewed only one partner in the household and only a few households per village. Our sample of 422 households is dispersed over 120 villages in the district of Kapchorwa. The gender of the respondent selected at random using stratification across genders to ensure balance in the sample of female and male participants (Figure 4.3).

Each household was visited twice. The BDM activity was conducted during the first visit. After completion of the experiment, participants were asked to answer a short questionnaire on socio-demographic characteristics and how they intend to spend the reward they earned. 5 to 7 days after the experiment, participants were visited again to answer another short questionnaire on their spending across different consumption categories in the past 7 days.

\section{Outcome variables of interest}

The main outcome variable in this study is the WTP for hiding income, providing both an indicator of the presence of inefficiency associated with household bargaining between spouses (WTP $>0$ ) and a measure of the extent of inefficiency. Positive WTP to keep money private is a measure of loss of efficiency since it quantifies how much the participant is willing to forgo household income to ensure that the partner remains unaware of the existence of the reward earned. Specifically, we use the ratio of stated WTP to the full reward (R) offered in order to account for the fact that we offered two rewards, one 15,000 UShs and one 30,000 UShs to different participants (randomly selected).

A second concern of this paper is on differences in intended and actual spending behaviours for spouses receiving their reward in private versus in public, and 
between male and female spouses. To this end, following the BDM activity participants were asked how they intended to spend the reward they earned across a range of expenditure categories that were classified into public and private expenditures. This provided a measure of expenditure intentions as an outcome of having a private income windfall versus a public income windfall, and by gender of the treated spouse.

On a second visit to the household 5-7 days after the experiment, participants were asked how they spent the reward. Answers were recorded into categories such as food, health-related expenses, gifts/transfers to household members, pleasure goods, transfers to social network, and farm-related expenses which were aggregated into broader categories such as observable household and unobservable personal expenses for the purposes of analysis. In particular, household spending includes spending for household needs, such as food and soap; health-related expenses; gifts/transfers to children and spouse; whereas unobservable private spending includes money spent for socializing with friends and pleasure goods such as sports betting, cigarettes and alcohol; personal care items for individual use; and transfers/gifts to social network (outside the household). Repayment of debt and loans are separately captured in another category as well as investment in farms or other businesses. See Table 4.7 for spending across all categories.

The first outcome of interest regarding spending behaviour is the intention to allocate the reward on unobservable personal consumption. It is a binary variable that takes the value 1 if the participant indicated that he/she had the intention to spend the reward on one or more of private spending categories () and 0 otherwise. The second outcome of interest is the intention to spend the reward for the household. It is also an indicator variable that takes the value 1 if the participant reported to have the intention to spend the reward for one or more of the household spending categories and 0 otherwise. Regarding actual spending, two other indicator variables that take the value of 1 if the participants indicated that they made private and household spending, respectively, and 0 otherwise. Note that participants were not asked how much of the reward they intend to spend or actually spent on which category. They could mention multiple categories of spending and answers were recorded in a select-all-that-apply fashion.

Weekly expenditure data were also collected on the second visit using a recall method. Participants were asked how much they spent on each category (as listed above) in the last 7 days. Listed categories were aggregated into broad categories such as observable household and unobservable personal expenses for the 
purposes of analysis. Then a ratio variable, private-to-household expenses, was created and log-transformed to capture the relative change in private personal to household spending.

\section{Explanatory variables}

To analyse factors that explain household bargaining inefficiency (as measured by WTP), variables considered as "drivers" of inefficiency include equality in decision making between partners, women's empowerment, conflict and aggression in the household, and membership in savings group among others.

To measure women's empowerment, an index variable was constructed based on 10 questions about the participant's input/say in household decisions (e.g. decisions regarding major and minor household expenditures, health-related expenses, farm-related expenses, how much to save, and leisure and enjoyment expenses). Input into decisions is commonly used to measure women's empowerment (Ashraf et al., 2014; Krumbiegel et al., 2017; Almas et al., 2018). In this study, answer options vary from no say (0), spouse is the only decision-maker, to full say (10), the participant is the only decision-maker. The variable to measure empowerment, input into household decisions, was constructed summing up the answers to questions regarding 10 different household decisions.

Equal input/say into these decisions between the spouses was recorded against the middle answer option (5). To capture equality of power in decisions, indicator variables for each of the 10 questions regarding decisions that take the value 1 if the participant indicates equal input (5) into the respective decision and 0 otherwise were generated. Then, these 10 equality indicators were summed for each of the 10 decisions to construct a variable that measures the varying degree of equality in decision-making between the spouses. These two variables, namely, input into household decisions and equal input in household decision, are constructed using the same decision-making questions but can be considered varying sensitivities to certain cut-offs (equality) and are elaborated together.

In addition, the relationship between domestic violence and female empowerment are commonly considered in the literature (Bobonis et al., 2015; Almas et al., 2018). As an indicator of difficulty in resolution of disagreements over household decisions and aggression, an index variable was constructed based on 7-point Likert-scale responses to 3 questions regarding the couple's difficulty in resolving conflicts, and frequency of verbal and physical aggression occurrences following 
Bradbury et al. (2000).

Other covariates include socio-demographic characteristics, whether the participant is a member of a savings group, participant's educational attainment in years, whether the participant engages in off-farm activities, number of years of (de facto) marriage, age differences between partners, number of children, and if the household exercises polygamy. Risk preferences were measured using 3 standard questions, such as "How would you rate your willingness to take risks in general/farming/with your life?" based on 7-point Likert scale answer options. Lastly, the number of households that received the reward in public in the village (of the participant) is used to proxy information spill-overs through neighbours.

\subsubsection{Descriptive Statistics}

Table 4.1 presents sample characteristics. Our sample consists of 422 individuals of whom 217 are women. There are large differences in socio-demographic characteristics of women and men in our sample. Average age is 41 years for women and 46 years for men. On average, women have 7.5 years while men have 10.5 years of education. 45 percent of women and 59 percent of men engage in offfarm activities. Average annual household income lies between 1 to 2 million UShs ( $\sim 360$ to 720 USD). Female participants own fewer assets and are more likely to be a member of a savings group than male participants. Average household size is 7. Polygamy is a relatively common marital arrangement in the area with 20 percent of the households reporting polygamous relationships.

Regarding outcome variables, there are large and significant differences between female and male participants. The share of participants who report to have the intention to spend and to have spent the reward for private consumption are significantly higher among men than women. Men also report to make significant higher household and private spending than women. Table 4.2 focuses on differences between households who receive the reward privately versus known by partner. On average, the two groups are balanced on their sociodemographic characteristics except on education and off-farm activities (significant only marginally). The socio-economic balance between household that received the reward in private and publicly shows that our random allocation of private rewards (conditional on stated WTP) worked as intended.

Participants who received the reward in private stated higher WTP to receive the reward in private which is expected since a higher WTP increased the probability 
Table 4.1: Characteristics of male and female participants

\begin{tabular}{lcccc}
\hline \hline & $\begin{array}{c}\text { Mean } \\
\text { Public } \\
(\mathrm{N}=139)\end{array}$ & $\begin{array}{c}\text { Mean } \\
\text { Private } \\
(\mathrm{N}=283)\end{array}$ & $\begin{array}{c}\text { Mean } \\
\text { Difference }\end{array}$ & $\begin{array}{c}\text { Std. } \\
\text { Dev. }\end{array}$ \\
\hline Age in years & 46.21 & 41.24 & $4.966^{* * *}$ & 0.846 \\
Highest education in years & 10.52 & 7.55 & $2.969^{* * *}$ & 0.470 \\
Off-farm employment incl. casual labour (0/1) & 0.59 & 0.45 & $0.139^{* * *}$ & 0.048 \\
Number of assets owned by participant & 1.01 & 0.50 & $0.512^{* * *}$ & 0.060 \\
Annual HH income (categorical 1-7) & 2.58 & 2.11 & $0.465^{* * *}$ & 0.095 \\
Number of years of marriage living together & 22.65 & 22.38 & 0.276 & 0.900 \\
Number of children & 5.13 & 4.93 & 0.201 & 0.208 \\
HH size & 7.55 & 7.09 & $0.459^{* *}$ & 0.241 \\
Polygamous HH (0/1) & 0.19 & 0.28 & $-0.091^{* *}$ & 0.041 \\
Equality in decision-making (0-10) & 2.89 & 3.94 & $-1.047^{* * *}$ & 0.246 \\
Input in decisions (0-100) & 67.51 & 54.13 & $13.383^{* * * *}$ & 1.266 \\
Conflict and aggression (3-21) & 5.61 & 6.36 & $-0.745^{* * *}$ & 0.226 \\
Participant is a member of a savings group (0/1) & 0.46 & 0.71 & $-0.251^{* * *}$ & 0.046 \\
\hline Stated WTP to hide income & 0.48 & 0.51 & -0.027 & 0.018 \\
Reward received (UShs) & 18631 & 19795 & 1163 & 732 \\
Intend to spend reward on private cons. (0/1) & 0.40 & 0.04 & $0.363^{* * *}$ & 0.036 \\
Intend to spend reward for HH (0/1) & 0.77 & 0.73 & 0.043 & 0.042 \\
Spent reward on private consumption (0/1) & 0.62 & 0.25 & $0.371^{* * *}$ & 0.045 \\
Spent reward for the HH (0/1) & 0.81 & 0.87 & -0.057 & 0.036 \\
Private spending weekly (Ushs) & 17439 & 3947 & $13491^{* *}$ & 1055 \\
HH spending weekly (Ushs) & 39085 & 33196 & $5889^{* * * *}$ & 3140 \\
\hline \hline
\end{tabular}

Notes: $* * * \mathrm{p}<0.01 * * \mathrm{p}<0.05 * \mathrm{p}<0.1$

to receive the reward in private. We control for WTP when analysing the spending outcomes. There is a significant difference in the reward value received between those who received the reward in front of their partner and in private. This is also expected since private reward recipients, by construction, receive a lower reward because they pay a price for secrecy. A more detailed breakdown of weekly spending across categories is provided in section 4.8 (Table 4.7).

\subsection{Estimation Strategy}

\subsubsection{Assessing willingness to pay to hide income}

The first step in analysing these data is to establish the existence of inefficiency regarding household bargaining outcomes for consumption decisions in participating households. The nature of our data allows quantification of the efficiency losses in terms of the amount of money that participants are willing to lose to maintain full control over income. Differences in the WTP statement are analysed between genders and between the two levels of reward amount offered (15,000 Ushs versus 30,000 Ushs). Additional 'drivers' of WTP statements are also analysed. 
Table 4.2: Characteristics of participants who received the reward privately and publicly

\begin{tabular}{lcccc}
\hline \hline & $\begin{array}{c}\text { Mean } \\
\text { Public } \\
(\mathrm{N}=139)\end{array}$ & $\begin{array}{c}\text { Mean } \\
\text { Private } \\
(\mathrm{N}=283)\end{array}$ & $\begin{array}{c}\text { Mean } \\
\text { Difference }\end{array}$ & $\begin{array}{c}\text { Std. } \\
\text { Dev. }\end{array}$ \\
\hline Age in years & 44.475 & 43.254 & 1.220 & 0.934 \\
Highest education in years & 9.626 & 8.686 & $0.940^{*}$ & 0.521 \\
Off-farm employment incl. casual labour (0/1) & 0.460 & 0.548 & $-0.088^{*}$ & 0.052 \\
Number of assets owned by participant & 0.820 & 0.717 & 0.103 & 0.069 \\
Annual HH income (categorical 1-7) & 2.439 & 2.286 & 0.153 & 0.104 \\
Number of years of marriage/living together & 22.576 & 22.481 & 0.095 & 0.957 \\
Number of children & 4.964 & 5.053 & -0.089 & 0.222 \\
HH size & 7.432 & 7.258 & 0.174 & 0.258 \\
Polygamous HH (0/1) & 0.209 & 0.244 & -0.035 & 0.044 \\
Equality in decision-making (0-10) & 3.396 & 3.449 & -0.053 & 0.267 \\
Input in decisions (0-100) & 61.604 & 60.152 & 1.452 & 1.514 \\
Conflict and aggression (3-21) & 5.906 & 6.049 & -0.143 & 0.244 \\
Participant is a member of a savings group (0/1) & 0.640 & 0.569 & 0.071 & 0.051 \\
\hline Stated WTP to hide income & 0.42 & 0.53 & $-0.111^{* * * *}$ & 0.019 \\
Reward received (UShs) & 22122 & 17760 & $4362^{* * *}$ & 751 \\
Intend to spend reward on private cons. (0/1) & 0.237 & 0.208 & 0.029 & 0.043 \\
Intend to spend reward for HH (0/1) & 0.849 & 0.700 & $0.149^{* * * *}$ & 0.044 \\
Spent reward on private cons. (0/1) & 0.489 & 0.406 & 0.083 & 0.051 \\
Spent reward for the HH (0/1) & 0.871 & 0.823 & 0.047 & 0.038 \\
Private spending weekly (Ushs) & 11299 & 10109 & 1190 & 3346 \\
HH spending weekly (Ushs) & 38982 & 34620 & 4361 & 1322 \\
\hline \hline
\end{tabular}

Notes: $* * * \mathrm{p}<0.01 * * \mathrm{p}<0.05 * \mathrm{p}<0.1$

Since the dependent variable is a fraction (i.e. the ratio of stated WTP to the full reward value offered) both a linear probability model (OLS) and a fractional response model (using logit) are estimated based on the relationship:

$$
p W T P_{i}=\alpha_{0}+\alpha_{1} T_{i}+X_{i}^{\prime} \delta+e_{i}
$$

where $p W T P_{i}$ is the proportion of stated WTP to reward and $T$ represents the key explanatory variables of interest (gender and reward level). Specifically, $T_{i}$ is an indicator variable that takes the value of 1 if the female decision maker of the household participated in the game or if the participant was in the higher-reward group and 0 otherwise. In explaining the efficiency losses in the household, additional explanatory variables of interest $X_{i}$ include participant's input in various decisions, such as input in household decisions and equality in decision-making.

The fractional response models are quasi-likelihood estimators that model the mean of the transformed dependent variable, $f(\mu x)$, conditional on covariates. The transformation used in this case is the Logit function that allows a gener- 
alised linear model representation of dependent variables that fall in the $0-1$ range (i.e. proportions). Note that to estimate the quasi-likelihood one need not know the true distribution of the entire model to obtain consistent parameter estimates (Wooldridge, 2010).

\subsubsection{Estimating the effect of private rewards on private and household spending}

The second objective of this paper is to estimate the effect of receiving the reward in private on consumption choices of participants. The key variables of interest $Y_{i}$ are whether the reward was intended to spend and spent on private and household consumption in addition to the log transformed ratio of the private-to-householdfocused (public) goods by the participant in the week following receipt of their reward. The following model is estimated separately on male and female subsamples using logit for the binary outcome variables and OLS for the last (continuous) outcome variable:

$$
Y_{i}=\beta_{0}+\beta_{1} P_{i}+X_{i}^{\prime} \delta+u_{i}
$$

The key treatment variable of interest is a binary treatment variable, $P_{i}$, indicating whether the participant received their reward in private $P_{i}=1$ or in front of their spouse $P_{i}=0 . X_{i}$ is a vector of covariates, such as gender, off-farm employment status of the participant, number of children, and membership in saving groups. Treatment is random conditional on stated WTP and WTP is also included in the estimations. Inclusion of WTP allows for capturing some unobservable characteristics in the households which may affect both receiving the reward in private and post-experiment consumption, such as decision-making dynamics and bargaining power. In addition, to control for the potential effect of information spill-overs within the village on spending behaviour, we incorporated the number of households in the village who received a public reward.

$\beta_{1}$ is the treatment effect under the identifying assumption that $P_{i}$ is orthogonal to $\mathrm{u}$. We rely on the quasi-random selection mechanism derived from the BDM activity to establish exogeneity of the receipt of private income. The randomisation is conditional on WTP which we control for in our estimations. However, one might argue that treatment is not as exogenous for participants who stated very low or very high WTP values. As a result, we also estimate the treatment effects on a restricted sample i.e. participants who stated WTP between one-third and 
two-thirds of the full reward offered to check robustness of the estimated treatment effects.

\subsection{Results}

In this section we first quantify efficiency losses arising from hiding income and document the factors that explain the WTP to hide income from spouse separately for women and men. In the second subsection, the effect of receiving the reward in private on household spending is assessed.

\subsubsection{Willingness to pay (WTP) to hide income}

A detailed table which presents the frequency of responses for each possible WTP across genders, reward value offered, and public/private rewards is provided in section 4.8 (Table 4.8). Only three participants (all male) in the sample stated zero WTP to keep the reward secret whereas almost all participants stated positive WTP to receive the reward private. The majority (53 percent) of the participants stated a WTP value of at least 50 percent of the full reward offered.

Of the 422 participants in our sample, one-third received the reward in full and in front of their partners as opposed to the two-thirds that received the reward in private. 72 percent of the female participants and 61 percent of the male participants received the reward in private. On average, those who had to pay to receive the payment in private (i.e. those who did not receive the full reward in front of their partner) received 77 percent of the full reward offered. The reward amount earned from the experiment was, on average, 19,197 UShs ( $\sim 7$ USD). Figure 4.1 presents the distribution of stated WTP as a fraction of the full reward offered across genders whereas Figure 4.2 presents the distributions for different reward levels.

Estimation results of WTP across genders are presented in Table 4.3. As indicated by the coefficient on the respective comparison group mean, average WTP values are approximately 50 percent of the reward value (Column 1). This result is similar across both men and women and reward values offered with no statistically significant differences (Column 2-4). The mean of the WTP distribution is significantly different from 0 (p-value $=0.000$ ) indicating that there are, on average, significant deviations from Pareto efficiency. The amount of household income that participants are willing to forgo corresponds to between 1-2 days agricultural wages in the study area indicating that the potential costs of non-cooperation in 
Figure 4.1: Distribution of stated WTP across genders

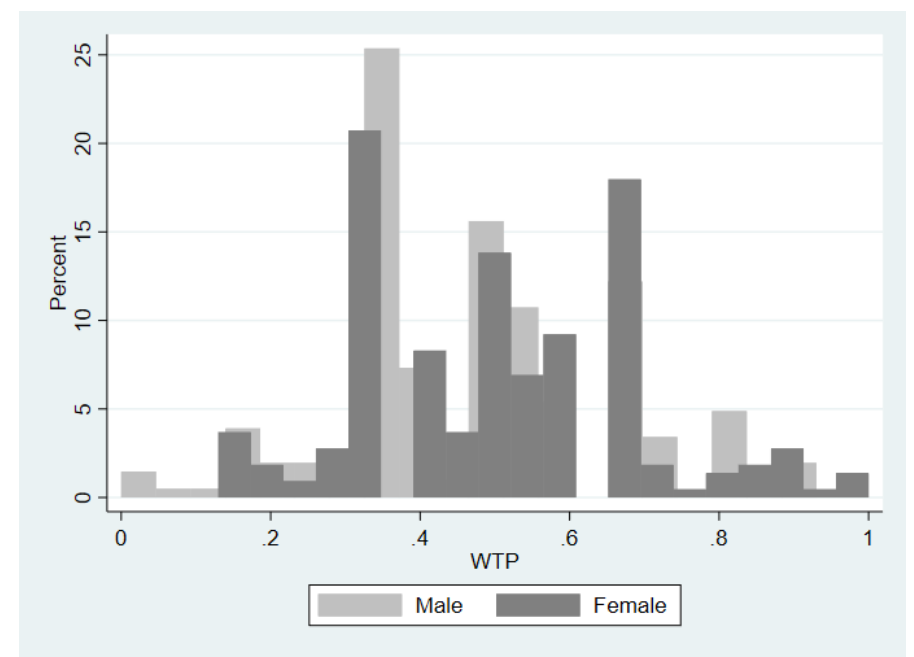

Figure 4.2: Distribution of stated WTP across rewards offered

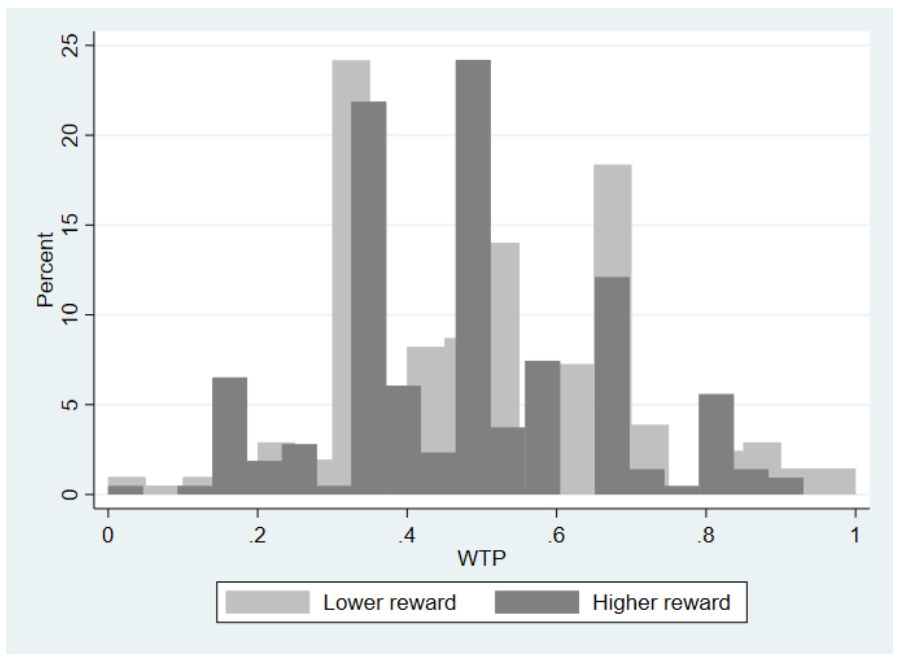

the household are substantial. There is some evidence that WTP diminishes in the size of rewards for women (Column 5) but not for men (Column 6).

\subsubsection{Drivers of WTP to hide income}

The determinants of WTP to keep income private were estimated using both a linear probability model and a fractional response model. Results are similar between the estimated models and summarised in Table 4.4. Here our focus is empowerment-related variables. Full specifications are provided in section 4.8 (Table 4.9).

Whilst WTP values are not significantly different between men and women (shown in Table 4.3), there are significant differences between the determinants of WTP 
Table 4.3: WTP to keep income private

\begin{tabular}{lcccccc}
\hline \hline & \multicolumn{7}{c}{ WTP to receive reward in private } \\
\hline & $\begin{array}{c}\text { Total } \\
(1)\end{array}$ & $\begin{array}{c}\text { High reward } \\
(2)\end{array}$ & $\begin{array}{c}\text { Low reward } \\
(3)\end{array}$ & $\begin{array}{c}\text { Total } \\
(4)\end{array}$ & $\begin{array}{c}\text { Female } \\
(5)\end{array}$ & $\begin{array}{c}\text { Male } \\
(6)\end{array}$ \\
\hline Female (0/1) & 0.0265 & 0.0138 & 0.0382 & & & \\
& -0.0182 & -0.025 & -0.0265 & & & \\
Higher reward (0/1) & & & & -0.0299 & $-0.0411^{*}$ & -0.0167 \\
& & & & -0.0182 & -0.0247 & -0.0268 \\
Comparison group & $0.479^{* * * *}$ & $0.471^{* * *}$ & $0.488^{* * *}$ & $0.508^{* * *}$ & $0.526^{* * * *}$ & $0.488^{* * * *}$ \\
mean & -0.0131 & -0.0177 & -0.0193 & -0.013 & -0.0174 & -0.0194 \\
& & & & & & \\
Observations & 422 & 215 & 207 & 422 & 217 & 205 \\
R-squared & 0.005 & 0.001 & 0.01 & 0.006 & 0.013 & 0.002 \\
\hline \hline
\end{tabular}

Notes: OLS estimations equivalent of t-test. Standard errors in parentheses. $* * * \mathrm{p}<0.01 * * \mathrm{p}<0.05$ $* \mathrm{p}<0.1$

of men and women. Women's empowerment, as measured by the subjective extent of women's input into various household decisions, does not significantly explain the stated WTP of women to hide income but is associated with a significant tendency for men to state a higher WTP. A larger say for men in the household increases willingness to hide income and associated efficiency losses. This implies that increased consideration of women's perspectives regarding household choices is associated with improved efficiency in these households.

Additionally, equality of partners in terms of their input into household decisions is negatively and significantly associated with WTP of women (but not significantly with WTP of men). Women who live in an equal household are less willing to hide income. The two variables, namely, input into household decisions and equal input in household decision, are constructed using the same decision-making questions but can be considered varying sensitivities of the male and female samples to equality. $^{2}$ For women it is particularly important to have an equal say in decisions (and not necessarily more say) which makes sense in a context where women rarely have more say than their husband. Taken together, these findings show that a higher consideration of women's input and a more equal decision-making between men and women lead to lower WTP to hide income and thus higher efficiency. There is thus a potential efficiency gain to households that can achieve greater levels of equality between men and women in terms of their roles as deci-

\footnotetext{
${ }^{2}$ One concern might be multicollinearity between these two variables. Correlation coefficient between input and equality in input remain around 0.5. A multicollinearity analysis indicates perfectly reasonable variance inflation factors (VIF) all being lower than 5 (Table 4.12). There is thus no problem of multicollinearity detected in the model used to estimate drivers of willingness to pay to hide income.
} 
sion makers.

Table 4.4: Drivers of WTP to keep income private

\begin{tabular}{lcccc}
\hline \hline & \multicolumn{3}{c}{ WTP to receive reward in private } \\
\hline & \multicolumn{2}{c}{ OLS } & \multicolumn{2}{c}{ FRM Marginal Effects } \\
\hline & Female & Male & Female & Male \\
& $(1)$ & $(2)$ & $(3)$ & $(4)$ \\
\hline Equal input in decision making (0-10) & $-0.0156^{* * *}$ & -0.0063 & $-0.0155^{* * *}$ & -0.0064 \\
& $(0.0056)$ & $(0.0077)$ & $(0.0053)$ & $(0.0072)$ \\
Input in decision making (0-100) & 0.0009 & $0.0045^{* * *}$ & 0.00094 & $0.0045^{* * *}$ \\
& $(0.0012)$ & $(0.0015)$ & $(0.0011)$ & $(0.0014)$ \\
Conflict and aggression (7-21) & $-0.0130^{* * *}$ & -0.0078 & $-0.0131^{* * *}$ & -0.0079 \\
& $(0.0045)$ & $(0.0093)$ & $(0.0040)$ & $(0.0090)$ \\
If member of a savings group (0/1) & $-0.058^{* *}$ & 0.0107 & $-0.0582 * *$ & 0.0111 \\
& $(0.0279)$ & $(0.0270)$ & $(0.0271)$ & $(0.0267)$ \\
Controls & Yes & Yes & Yes & Yes \\
Observations & 217 & 205 & 217 & 205 \\
R-squared & 0.123 & 0.173 & & \\
\hline \hline
\end{tabular}

Notes: FRM refers to Fractional Response Model. Controls include age, education, off-farm work status, risk preferences of the respondent, age difference between partners, number of years of marriage, number of children and assets owned, and whether the household is polygamous. Standard errors in parentheses. ${ }^{* * *} \mathrm{p}<0.01 * * \mathrm{p}<0.05 * \mathrm{p}<0.1$

Additionally, female participants who report higher levels of difficulty in resolving conflicts and higher occurrences of verbal and physical aggression tend to state lower WTP. While it may sound counter-intuitive at first glance from the perspective of women's empowerment, a plausible explanation is that women who are exposed to aggression more often might try to avoid the potentially unfavourable consequences of hiding money in particular of being found out. WTP to hide income is potentially driven by the differing preferences about allocations but tempered by the fear of being found out. In households where conflicts are more difficult to resolve and there are higher occurrences of violence, costs of receiving money secret private from spouse may outweigh the benefits particularly for women. This is consistent with the findings of Almas et al. (2018) who document a negative relationship between domestic violence and WTP of women to receive a cash transfer otherwise offered to the husband. Overall, women's empowerment, decision-making and conflict resolution dynamics are significantly associated with efficiency in the household, in this case, in terms of household earnings.

In addition, there is also a significant positive relationship between efficiency (as measured by a lower WTP) and membership in savings groups. Specifically, women who are a member of a local savings group tend to state lower WTP. One can imagine that financial holdings might be associated with empowerment, which in turn affects WTP, but the association between being a member of a sav- 
ings group and empowerment is statistically insignificant. Another explanation is that women with some financial holdings might not have the financial incentives to hide money from their husband, for instance, to have discretionary spending. Lastly, membership in savings groups may be associated with establishment of household norms over the treatment of windfall income gains, such as the rewards, reducing claims over money by household members. Given the recent focus on savings-group interventions in development research (e.g. Ksoll et al. (2016)) this result indicates there is potential for those interventions to reduce the tendency to hide income in households.

\subsubsection{Private versus household consumption}

In the first survey after the BDM activity participants were asked how they intended to spend the reward earned while in the follow-up survey how they actually spent the reward earned. We model intention to spend and spending the reward on private versus household expenses using a logistic regression. Using the data collected on weekly consumption, we also analyse the ratio of private unobservable spending to household spending to capture relative increase in private consumption. WTP to hide income from spouse is included in all specifications since randomisation of rewards is conditional on WTP and also to control for the factors that might affect household decision-making such as empowerment and bargaining power.

Table 4.5 presents the estimation results for men and women separately. Results indicate that receiving a private reward is positively associated with intention to use it for personal consumption for men and negatively and significantly for women (Column 1 and 2). Female participants are 3 percentage points less likely to have the intention to spend the reward on private consumption when the reward is private, which is a large effect give that only 4 percent of the female participants, on average, indicated to have the intention to spend the reward on private consumption. This result is significant at the 5 percent level. On the other hand, male participants who received the reward in private have a significantly lower probability ( 25 percentage points) of intending to use it for the household goods (Column 4). These findings are in line with the literature that documents higher personal and discretionary spending of men than women (Robinson, 2012) and those that support putting earnings in women's hands to speed up development for women often invest a larger portion of their resources in their families and communities than men (Duflo, 2003; Gertler, 2004; De Janvry and Sadoulet, 2006). 
Table 4.5: Intended and actual private versus household spending on female and male subsamples

\begin{tabular}{|c|c|c|c|c|c|c|c|c|c|c|}
\hline & \multicolumn{2}{|c|}{$\begin{array}{c}\text { Intend to spend } \\
\text { on private exp. }(0 / 1)\end{array}$} & \multicolumn{2}{|c|}{$\begin{array}{l}\text { Intend to spend } \\
\text { for } \mathrm{HH}(0 / 1)\end{array}$} & \multicolumn{2}{|c|}{$\begin{array}{l}\text { Reward spent on } \\
\text { private exp. }(0 / 1)\end{array}$} & \multicolumn{2}{|c|}{$\begin{array}{l}\text { Reward spent on } \\
\text { HH exp. }(0 / 1)\end{array}$} & \multicolumn{2}{|c|}{$\begin{array}{c}\text { Ratio of private to } \\
\text { HH expenditures (log) }\end{array}$} \\
\hline & & Margin & 1 Effects & & & Margin & 1 Effects & & & \\
\hline & $\begin{array}{c}\text { Female } \\
\text { (1) }\end{array}$ & $\begin{array}{l}\text { Male } \\
(2)\end{array}$ & $\begin{array}{c}\text { Female } \\
\text { (3) }\end{array}$ & $\begin{array}{l}\text { Male } \\
(4)\end{array}$ & $\begin{array}{c}\text { Female } \\
(5)\end{array}$ & $\begin{array}{l}\text { Male } \\
(6)\end{array}$ & $\begin{array}{c}\text { Female } \\
(7)\end{array}$ & $\begin{array}{c}\text { Male } \\
(8)\end{array}$ & $\begin{array}{l}\text { Female } \\
(9)\end{array}$ & $\begin{array}{l}\text { Male } \\
(10)\end{array}$ \\
\hline Reward received in private $(0 / 1)$ & $\begin{array}{l}-0.0327^{* * *} \\
(0.0130)\end{array}$ & $\begin{array}{c}0.0351 \\
(0.0769)\end{array}$ & $\begin{array}{l}-0.0162 \\
(0.0731)\end{array}$ & $\begin{array}{l}-0.249 * * * * \\
(0.0932)\end{array}$ & $\begin{array}{c}0.0382 \\
(0.0701)\end{array}$ & $\begin{array}{l}-0.0985 \\
(0.0796)\end{array}$ & $\begin{array}{l}-0.0102 \\
(0.0576)\end{array}$ & $\begin{array}{l}-0.0278 \\
(0.0619)\end{array}$ & $\begin{array}{l}0.573^{* * *} \\
(0.273)\end{array}$ & $\begin{array}{l}0.275^{*} \\
(0.142)\end{array}$ \\
\hline WTP & $\begin{array}{c}0.0629 \\
(0.0550)\end{array}$ & $\begin{array}{c}0.513^{* * * *} \\
(0.174)\end{array}$ & $\begin{array}{l}-0.0231 \\
(0.175)\end{array}$ & $\begin{array}{l}-0.333^{*} \\
(0.179)\end{array}$ & $\begin{array}{l}-0.0466 \\
(0.173)\end{array}$ & $\begin{array}{c}0.533^{* * * *} \\
(0.193)\end{array}$ & $\begin{array}{l}-0.119 \\
(0.133)\end{array}$ & $\begin{array}{c}-0.553^{* * * *} \\
(0.134)\end{array}$ & $\begin{array}{l}-0.903 \\
(0.663)\end{array}$ & $\begin{array}{l}-0.0116 \\
(0.347)\end{array}$ \\
\hline If member of a savings group $(0 / 1)$ & $\begin{array}{l}-0.0179 \\
(0.0194)\end{array}$ & $\begin{array}{c}-0.110 \\
(0.0688)\end{array}$ & $\begin{array}{c}0.111^{*} \\
(0.0645)\end{array}$ & $\begin{array}{c}0.0210 \\
(0.0661)\end{array}$ & $\begin{array}{c}0.0343 \\
(0.0677)\end{array}$ & $\begin{array}{c}0.0136 \\
(0.0706)\end{array}$ & $\begin{array}{l}0.00242 \\
(0.0525)\end{array}$ & $\begin{array}{l}0.138 * * \\
(0.0536)\end{array}$ & $\begin{array}{l}0.0451 \\
(0.269)\end{array}$ & $\begin{array}{c}-0.542^{* * *} \\
(0.128)\end{array}$ \\
\hline Works off-farm $(0 / 1)$ & $\begin{array}{l}-0.0258 \\
(0.0238)\end{array}$ & $\begin{array}{l}-0.121 * \\
(0.0695)\end{array}$ & $\begin{array}{c}0.0569 \\
(0.0625)\end{array}$ & $\begin{array}{l}-0.386^{* * * *} \\
(0.0713)\end{array}$ & $\begin{array}{c}-0.207 * * * \\
(0.0604)\end{array}$ & $\begin{array}{l}-0.0775 \\
(0.0712)\end{array}$ & $\begin{array}{l}0.110 * * \\
(0.0530)\end{array}$ & $\begin{array}{c}-0.290 * * * \\
(0.0754)\end{array}$ & $\begin{array}{l}0.0541 \\
(0.231)\end{array}$ & $\begin{array}{c}0.191 \\
(0.129)\end{array}$ \\
\hline Number of children & $\begin{array}{c}0.00131 \\
(0.00369)\end{array}$ & $\begin{array}{c}-0.0375^{* *} \\
(0.0159)\end{array}$ & $\begin{array}{l}0.00381 \\
(0.0142)\end{array}$ & $\begin{array}{l}-0.0123 \\
(0.0154)\end{array}$ & $\begin{array}{l}-0.0110 \\
(0.0137)\end{array}$ & $\begin{array}{l}0.00288 \\
(0.0161)\end{array}$ & $\begin{array}{l}-0.00678 \\
(0.0105)\end{array}$ & $\begin{array}{l}-0.00637 \\
(0.0119)\end{array}$ & $\begin{array}{l}-0.0480 \\
(0.0561)\end{array}$ & $\begin{array}{l}-0.0424 \\
(0.0288)\end{array}$ \\
\hline Polygamous HH $(0 / 1)$ & $\begin{array}{l}-0.00727 \\
(0.0204)\end{array}$ & $\begin{array}{c}0.0216 \\
(0.0857)\end{array}$ & $\begin{array}{l}-0.0149 \\
(0.0672)\end{array}$ & $\begin{array}{c}0.0650 \\
(0.0854)\end{array}$ & $\begin{array}{l}-0.0977 \\
(0.0690)\end{array}$ & $\begin{array}{l}-0.0740 \\
(0.0859)\end{array}$ & $\begin{array}{c}0.0448 \\
(0.0560)\end{array}$ & $\begin{array}{c}0.0610 \\
(0.0693)\end{array}$ & $\begin{array}{c}0.181 \\
(0.259)\end{array}$ & $\begin{array}{l}-0.0570 \\
(0.158)\end{array}$ \\
\hline Reward received (UShs) & $\begin{array}{c}0.00001 \\
(0.00001)\end{array}$ & $\begin{array}{c}0.00002 \\
(0.00004)\end{array}$ & $\begin{array}{c}0.00003 \\
(0.00004)\end{array}$ & $\begin{array}{c}0.00006 \\
(0.00004)\end{array}$ & $\begin{array}{c}0.00002 \\
(0.00004)\end{array}$ & $\begin{array}{c}0.00002 \\
(0.00005)\end{array}$ & $\begin{array}{c}0.00003 \\
(0.00003)\end{array}$ & $\begin{array}{l}-0.00005 \\
(0.00003)\end{array}$ & $\begin{array}{c}0.00007 \\
(0.00002)\end{array}$ & $\begin{array}{c}0.00001 \\
(0.00008)\end{array}$ \\
\hline $\begin{array}{l}\text { Number of public reward } \\
\text { recipients in the village }\end{array}$ & & & & & $\begin{array}{l}-0.0859 \\
(0.0975)\end{array}$ & $\begin{array}{c}0.179 \\
(0.113)\end{array}$ & $\begin{array}{l}0.0885 \\
(0.107)\end{array}$ & $\begin{array}{l}-0.0311 \\
(0.0528)\end{array}$ & $\begin{array}{l}-0.336 \\
(0.321)\end{array}$ & $\begin{array}{c}0.138 \\
(0.129)\end{array}$ \\
\hline $\begin{array}{l}\text { Observations } \\
\text { R-squared }\end{array}$ & 217 & 205 & 217 & 205 & 217 & 205 & 217 & 205 & $\begin{array}{c}86 \\
0.082\end{array}$ & $\begin{array}{c}195 \\
0.165\end{array}$ \\
\hline
\end{tabular}

\footnotetext{
Notes: Standard errors in parentheses. $* * * \mathrm{p}<0.01 * * \mathrm{p}<0.05 * \mathrm{p}<0.1$
} 
Despite the significant treatment effects on intended spending, we do not detect any statistically significant treatment effect on the probability of having allocated the reward on private or household consumption. This holds for both men and women (Column 5-8).

Note that one-third of the participants in our sample reported to have no private consumption within the last 7 days and a large majority of them are women. While this is an interesting result itself, participants with no private spending are excluded from the analysis of private-to-household spending and thus the sample size is smaller for this variable (Column 9 and 10). For those with positive private spending, the effect of receiving the reward in private on the ratio of private to household-focused consumption is positive and significant. This holds for both men and women and the effect is larger for women (57 percent) than men (28 percent).

Analysing the breakdown, men's reported spending on socializing and pleasure goods account for 92 percent of all private spending, whereas close to half of private spending reported by women was transferred to their social network (Table 4.7). This result is perfectly consistent with Castilla and Walker (2012) who document, when a private prize is received, men increase their alcohol consumption and gifts to their social network, whereas the women lend the money out to arguably make it difficult for their husband to have claims over the money. Several studies in the literature claim that women are more cautious with money and prefer to keep money by themselves mainly to prevent their husbands from using the money unwisely (Fiala and He, 2017).

Additionally, the share of money put aside (in weekly spending) is higher for women who received the reward in private than in front of their husbands (pvalue $=0.045$ ). It may well be the case that women who received the reward in private used the opportunity that they had the control over the money and put the money aside for future transactions. This scenario is likely particularly given that women are more likely to be a member of a savings group than men. This is highly consistent with the findings in the literature. 
Table 4.6: Intended and actual private versus household spending on subsamples of high and low rewards offered

\begin{tabular}{|c|c|c|c|c|c|c|c|c|c|c|}
\hline & \multicolumn{2}{|c|}{$\begin{array}{c}\text { Intend to spend } \\
\text { on private exp. }(0 / 1)\end{array}$} & \multicolumn{2}{|c|}{$\begin{array}{l}\text { Intend to spend } \\
\text { for } \mathrm{HH}(0 / 1)\end{array}$} & \multicolumn{2}{|c|}{$\begin{array}{l}\text { Reward spent on } \\
\text { private exp. }(0 / 1)\end{array}$} & \multicolumn{2}{|c|}{$\begin{array}{l}\text { Reward spent on } \\
\text { HH exp. }(0 / 1)\end{array}$} & \multicolumn{2}{|c|}{$\begin{array}{c}\text { Ratio of private to } \\
\text { HH expenditures (log) }\end{array}$} \\
\hline & \multicolumn{4}{|c|}{ Marginal Effects } & \multicolumn{4}{|c|}{ Marginal Effects } & \multicolumn{2}{|c|}{ OLS } \\
\hline & $\begin{array}{l}\text { High } \\
\text { reward } \\
(1)\end{array}$ & $\begin{array}{l}\text { Low } \\
\text { reward } \\
(2)\end{array}$ & $\begin{array}{l}\text { High } \\
\text { reward } \\
(3)\end{array}$ & $\begin{array}{l}\text { Low } \\
\text { reward } \\
(4)\end{array}$ & $\begin{array}{l}\text { High } \\
\text { reward } \\
(5)\end{array}$ & $\begin{array}{l}\text { Low } \\
\text { reward } \\
(6)\end{array}$ & $\begin{array}{l}\text { High } \\
\text { reward } \\
(7)\end{array}$ & $\begin{array}{l}\text { Low } \\
\text { reward } \\
(8)\end{array}$ & $\begin{array}{l}\text { High } \\
\text { reward } \\
(9)\end{array}$ & $\begin{array}{l}\text { Low } \\
\text { reward } \\
(10)\end{array}$ \\
\hline Reward received in private $(0 / 1)$ & $\begin{array}{l}-0.0628 \\
(0.0640)\end{array}$ & $\begin{array}{l}-0.0364 \\
(0.0663)\end{array}$ & $\begin{array}{l}-0.251^{* *} \\
(0.119)\end{array}$ & $\begin{array}{l}-0.123 \\
(0.110)\end{array}$ & $\begin{array}{c}-0.106 \\
(0.0867)\end{array}$ & $\begin{array}{c}0.0446 \\
(0.0958)\end{array}$ & $\begin{array}{c}-0.101 \\
(0.0832)\end{array}$ & $\begin{array}{c}0.0534 \\
(0.0674)\end{array}$ & $\begin{array}{l}-0.0331 \\
(0.219)\end{array}$ & $\begin{array}{l}0.430 * \\
(0.229)\end{array}$ \\
\hline Female $(0 / 1)$ & $\begin{array}{l}-0.396 * * * \\
(0.0631)\end{array}$ & $\begin{array}{l}-0.321 * * * \\
(0.0645)\end{array}$ & $\begin{array}{l}-0.0702 \\
(0.0703)\end{array}$ & $\begin{array}{l}-0.0573 \\
(0.0702)\end{array}$ & $\begin{array}{l}-0.337 * * * \\
(0.0523)\end{array}$ & $\begin{array}{l}-0.376 * * * \\
(0.0476)\end{array}$ & $\begin{array}{c}0.0577 \\
(0.0580)\end{array}$ & $\begin{array}{l}-0.00622 \\
(0.0480)\end{array}$ & $\begin{array}{l}-0.814^{* * * *} \\
(0.174)\end{array}$ & $\begin{array}{c}-0.920 * * * \\
(0.178)\end{array}$ \\
\hline WTP & $\begin{array}{l}0.350 * * * \\
(0.128)\end{array}$ & $\begin{array}{c}0.178 \\
(0.134)\end{array}$ & $\begin{array}{l}-0.173 \\
(0.191)\end{array}$ & $\begin{array}{l}-0.245 \\
(0.189)\end{array}$ & $\begin{array}{l}0.339 * \\
(0.176)\end{array}$ & $\begin{array}{c}0.160 \\
(0.187)\end{array}$ & $\begin{array}{l}-0.451 * * * \\
(0.146)\end{array}$ & $\begin{array}{l}-0.188 \\
(0.137)\end{array}$ & $\begin{array}{l}-0.362 \\
(0.436)\end{array}$ & $\begin{array}{l}-0.647 \\
(0.456)\end{array}$ \\
\hline If member of a savings group $(0 / 1)$ & $\begin{array}{l}-0.0910 * \\
(0.0493)\end{array}$ & $\begin{array}{l}-0.0462 \\
(0.0482)\end{array}$ & $\begin{array}{c}0.0725 \\
(0.0694)\end{array}$ & $\begin{array}{c}0.0993 \\
(0.0705)\end{array}$ & $\begin{array}{l}0.00346 \\
(0.0660)\end{array}$ & $\begin{array}{c}0.0454 \\
(0.0676)\end{array}$ & $\begin{array}{l}0.117 * * \\
(0.0547)\end{array}$ & $\begin{array}{c}0.0418 \\
(0.0485)\end{array}$ & $\begin{array}{l}-0.178 \\
(0.165)\end{array}$ & $\begin{array}{c}-0.649 * * * \\
(0.169)\end{array}$ \\
\hline Works off-farm $(0 / 1)$ & $\begin{array}{l}-0.0559 \\
(0.0501)\end{array}$ & $\begin{array}{l}-0.0841^{*} \\
(0.0501)\end{array}$ & $\begin{array}{l}-0.110 \\
(0.0678)\end{array}$ & $\begin{array}{l}-0.0850 \\
(0.0683)\end{array}$ & $\begin{array}{l}-0.143 * * \\
(0.0621)\end{array}$ & $\begin{array}{l}-0.153 * * \\
(0.0653)\end{array}$ & $\begin{array}{l}-0.0731 \\
(0.0563)\end{array}$ & $\begin{array}{l}-0.0678 \\
(0.0488)\end{array}$ & $\begin{array}{l}0.332 * * \\
(0.157)\end{array}$ & $\begin{array}{l}-0.0416 \\
(0.168)\end{array}$ \\
\hline Number of children & $\begin{array}{l}-0.0119 \\
(0.0118)\end{array}$ & $\begin{array}{l}-0.0177 \\
(0.0110)\end{array}$ & $\begin{array}{l}-0.00339 \\
(0.0168)\end{array}$ & $\begin{array}{l}0.00893 \\
(0.0150)\end{array}$ & $\begin{array}{l}-0.00565 \\
(0.0153)\end{array}$ & $\begin{array}{l}-0.00391 \\
(0.0141)\end{array}$ & $\begin{array}{l}-0.0191 \\
(0.0129)\end{array}$ & $\begin{array}{l}0.00747 \\
(0.0106)\end{array}$ & $\begin{array}{l}-0.0316 \\
(0.0364)\end{array}$ & $\begin{array}{l}-0.0541 \\
(0.0375)\end{array}$ \\
\hline Polygamous HH $(0 / 1)$ & $\begin{array}{l}0.00607 \\
(0.0588)\end{array}$ & $\begin{array}{l}-0.00733 \\
(0.0603)\end{array}$ & $\begin{array}{l}-0.0226 \\
(0.0771)\end{array}$ & $\begin{array}{c}0.0355 \\
(0.0826)\end{array}$ & $\begin{array}{l}-0.0754 \\
(0.0740)\end{array}$ & $\begin{array}{c}-0.104 \\
(0.0783)\end{array}$ & $\begin{array}{c}0.120^{*} \\
(0.0725)\end{array}$ & $\begin{array}{l}0.00366 \\
(0.0565)\end{array}$ & $\begin{array}{c}-0.242 \\
(0.188)\end{array}$ & $\begin{array}{c}0.323 \\
(0.199)\end{array}$ \\
\hline Reward received (UShs) & $\begin{array}{l}-0.00002 \\
(0.0007)\end{array}$ & $\begin{array}{c}-0.00001 \\
(0.00001)\end{array}$ & $\begin{array}{l}-0.00003 \\
(0.00008)\end{array}$ & $\begin{array}{l}-0.00001 \\
(0.00001)\end{array}$ & $\begin{array}{l}-0.00003 \\
(0.00009)\end{array}$ & $\begin{array}{c}0.00001 \\
(0.00001)\end{array}$ & $\begin{array}{l}-0.0002^{*} \\
(0.00008)\end{array}$ & $\begin{array}{l}0.00001 * \\
(0.00001)\end{array}$ & $\begin{array}{l}-0.00003 \\
(0.00002)\end{array}$ & $\begin{array}{c}0.00004 \\
(0.00004\end{array}$ \\
\hline $\begin{array}{l}\text { Number of public reward } \\
\text { recipients in the village }\end{array}$ & & & & & $\begin{array}{l}-0.0266 \\
(0.0841)\end{array}$ & $\begin{array}{l}-0.0660 \\
(0.0766)\end{array}$ & $\begin{array}{l}-0.0482 \\
(0.0685)\end{array}$ & $\begin{array}{l}-0.0261 \\
(0.0479)\end{array}$ & $\begin{array}{l}-6.92 \mathrm{e}-05 \\
(0.221)\end{array}$ & $\begin{array}{l}-0.0601 \\
(0.169)\end{array}$ \\
\hline $\begin{array}{l}\text { Observations } \\
\text { R-squared }\end{array}$ & 215 & 207 & 215 & 207 & 215 & 207 & 215 & 207 & $\begin{array}{c}153 \\
0.238\end{array}$ & $\begin{array}{c}139 \\
0.355\end{array}$ \\
\hline
\end{tabular}

Notes: Standard errors in parentheses. $* * * \mathrm{p}<0.01 * * \mathrm{p}<0.05 * \mathrm{p}<0.1$ 
For instance, Anderson and Baland (2002) argue that participation in a savings group is a strategy employed by married women to protect their savings against claims by their husband for immediate consumption in Kenya. Membership in saving groups is associated negatively with private spending and positively with household spending. One plausible explanation is that membership in savings groups may help establish norms in the household regarding how to treat cash windfalls encouraging savings. Our results thus suggest a potential for groupbased savings interventions to increase the tendency to save money and reduce the tendency to spend it "unwisely" in particular in rural areas where people lack access to formal institutions. Results are robust to restriction of the sample to participants who stated WTP between 0.33 and 0.67 of the full reward offered in terms of direction, size, and significance levels in most cases (Table 4.10).

Lastly, Table 4.6 presents the treatment effect separately on respondents who were offered high and low rewards. High-reward participants are less likely to spend the reward on household spending (Column 3). In addition, the effect of private rewards on the ratio of private expenses to observable household spending is positive and significant for those who were in the low-rewards treatment, whereas insignificant (and negative) for households in the high-reward treatment (Column 9-10). The positive coefficient of private rewards on ratio of private to household spending for the lower reward recipients is larger and more significant on the restricted sample i.e. participants for whom receiving a private reward was more exogenous than on the full sample (Table 4.11).

The difference in the direction of the effect of private rewards between low and high-reward treatment suggests that small and large windfalls received in private might be used for different purposes in the households. Our experiment is underpowered to conduct further subgroup analysis. However, one result that remains is that women are less likely to spend the rewards on private consumption and have lower shares of private spending (weekly) than men regardless of the size of the reward offered.

\subsection{Conclusion}

Employing an established revealed preference method, we elicited willingness to pay of either men or women to receive a reward in private versus in front of their partner in 422 households in rural Uganda. Willingness to pay to hide income allows for quantification of potential efficiency losses in the household since individuals trade-off household income for control over that income. Households 
were willing to give out, on average, 50 percent of the reward to keep it secret indicating substantial efficiency losses in the household and invalidating the hypothesis of Pareto efficiency. There are no large differences in the stated WTP to hide income across genders nor across the size of the rewards offered to the participants.

Linkages between observed household bargaining inefficiency (as measured by WTP) and empowerment-related variables were assessed using regression analysis. Variables considered as drivers of inefficiency include equality in decision making between partners, women's empowerment, conflict and aggression in the marriage, and membership in savings group. Drivers of the WTP to hide income differ for men and women. Equality in say in various household decisions is negatively associated with WTP of women to hide income. Men's WTP and associated inefficiency, however, are increasing in the input they have in household decisions indicating that a larger say for their wives potentially improve efficiency. Overall, an increase in the say women have in household decision and, in particular, equality in decision-making by spouses, has a potential to generate improved efficiency in the household behaviour - as stipulated by the cooperative household model.

This study represents an important contribution to the household behaviour literature by using an established method in a novel context to test efficiency of household behaviour, and analysing the relatively unexplored drivers of willingness to hide income from spouse, such as equality in decision-making power, conflict and aggression in the marriage, and membership in savings groups as well as the effect of asymmetric information on private versus public spending separately for men and women.

Non-cooperative household members appear to hide income to avoid claims over resources by each other and potentially alter consumption choices to their advantage. Our analysis show that private reward recipients are less likely to have the intention to spend the reward for their household and more likely for private expenses compared to public reward recipients. This effect is particularly strong and significant for men. In the week following the experiment, private spending in relation to household spending increases as a result of receiving the reward in private both for women and men. Women with positive private spending transfer money to others in their social network, whereas men's private consumption consists mostly of socializing and pleasure goods.

Women who are a member of savings group tend to state a lower WTP and are 
also less likely to allocate resources towards private spending and more likely to use it for their household. It appears that men's willingness to hide income relates to a preference towards private spending, whereas women's willingness to hide income might arise from a need to avoid claims over income by their husband for private spending so that the money can be put aside. Our findings suggest a major role for savings groups and financial inclusion interventions to reduce the tendency to hide income and associated inefficiency losses, and to increase the tendency to save and perhaps shift resources towards household goods potentially through changing household norms.

This study contributes to the understanding of behaviour of rural households in developing countries particularly in terms of decision-making dynamics and consumption choices and have important policy implications on the effectiveness of development interventions, such as social protection, financial inclusion, and value chain development activities, all of which are powerful tools to lift people out of poverty.

\subsection{Additional Figures and Tables}

Figure 4.3: Treatment status of the households in our sample

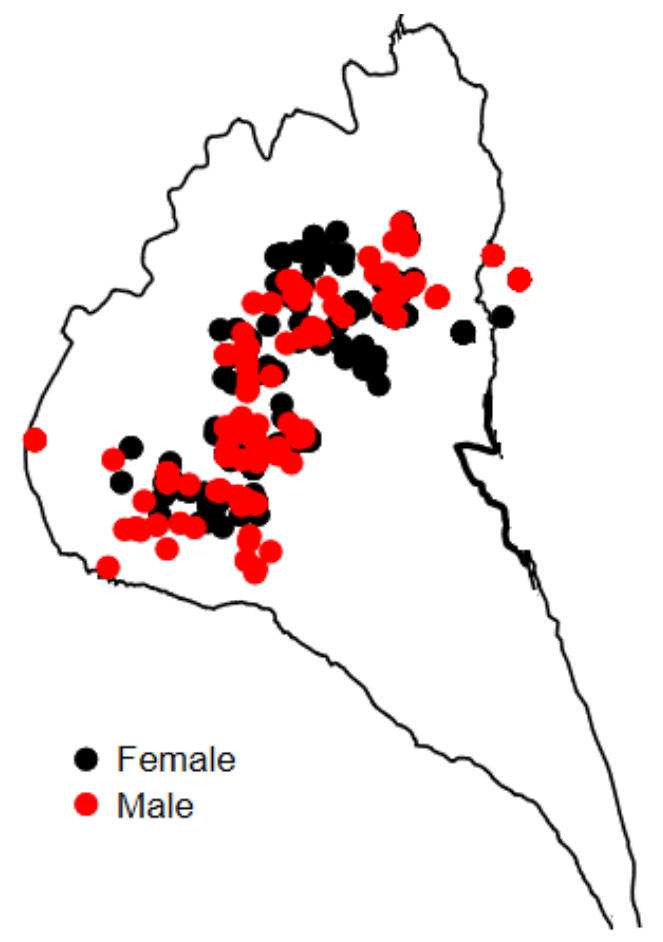


Table 4.7: Private and public spending across genders and rewards received

\begin{tabular}{lcccc}
\hline \hline Female participant & Mean & Std. Dev & Min & Max \\
Private reward (N=157) & & & & \\
\hline Personal spending (socializing, drinking etc) & 2691 & 4877 & 0 & 35000 \\
Transfers to outside HH & 1592 & 5932 & 0 & 50000 \\
HH needs (food, soap etc) & 22984 & 21502 & 0 & 150000 \\
Gifts/transfers to children or spouse & 2936 & 9400 & 0 & 60000 \\
Health-related expenses & 6685 & 15322 & 0 & 100000 \\
Savings & 7484 & 24594 & 0 & 300000 \\
Investment in business or farm & 16975 & 62744 & 0 & 650000 \\
Debt/loan repayment & 4166 & 18702 & 0 & 200000 \\
\hline Female participant & Mean & Std. Dev & Min & Max \\
Public reward (N=60) & & & & \\
\hline Personal spending (socializing, drinking etc) & 2733 & 4657 & 0 & 20000 \\
Transfers to outside HH & 333 & 2031 & 0 & 15000 \\
HH needs (food, soap etc) & 25575 & 20116 & 0 & 100000 \\
Gifts/transfers to children or spouse & 2350 & 6532 & 0 & 30000 \\
Health-related expenses & 6817 & 21615 & 0 & 150000 \\
Savings & 6617 & 11473 & 0 & 50000 \\
Investment in business or farm & 16400 & 39838 & 0 & 200000 \\
Debt/loan repayment & 11767 & 65720 & 0 & 500000 \\
\hline Male participant & Mean & Std. Dev & Min & Max \\
Private reward (N=126) & 16074 & 10722 & 0 & 60000 \\
\hline Personal spending (socializing, drinking etc) & 1294 & 5273 & 0 & 50000 \\
Transfers to outside HH & 28179 & 17901 & 0 & 100000 \\
HH needs (food, soap etc) & 5067 & 9561 & 0 & 50000 \\
Gifts/transfers to children or spouse & 3885 & 15451 & 0 & 150000 \\
Health-related expenses & 11857 & 47516 & 0 & 500000 \\
Savings & 16730 & 43344 & 0 & 300000 \\
Investment in business or farm & 23008 & 147105 & 0 & 1450000 \\
Debt/loan repayment & Mean & Std. Dev & Min & \multirow{2}{*}{ Max } \\
\hline Male participant & 16716 & 12705 & 0 & 60000 \\
Public reward (N=79) & 2835 & 2775 & 0 & 20000 \\
\hline Personal spending (socializing, drinking etc) & 15704 & 1000 & 70000 \\
Transfers to outside HH & 6899 & 14743 & 0 & 80000 \\
HH needs (food, soap etc) & 6405 & 19064 & 0 & 120000 \\
Gifts/transfers to children or spouse & 36291 & 225400 & 0 & 2000000 \\
Health-related expenses & 21466 & 55594 & 0 & 412000 \\
Savings & 27867 & 89879 & 0 & 700000 \\
Investment in business or farm & & & \\
Debt/loan repayment & & & \\
\hline \hline & 1650 & & \\
\hline
\end{tabular}


Table 4.8: WTP values across genders, rewards offered and rewards received

\begin{tabular}{|c|c|c|c|c|c|c|c|c|}
\hline \multirow[b]{2}{*}{$\begin{array}{c}\text { WTP } \\
\text { (fraction) }\end{array}$} & \multicolumn{3}{|c|}{ Offered high reward } & \multicolumn{3}{|c|}{ Offered low reward } & \multicolumn{2}{|c|}{ Total } \\
\hline & $\begin{array}{c}\text { WTP } \\
\text { (UShs) }\end{array}$ & Male & Female & $\begin{array}{c}\text { WTP } \\
\text { (UShs) }\end{array}$ & Male & Female & $\begin{array}{c}\text { Received } \\
\text { public rew. }\end{array}$ & $\begin{array}{c}\text { Received } \\
\text { private rew. }\end{array}$ \\
\hline 0.00 & 0 & 1 & & 0 & 2 & & 3 & \\
\hline 0.03 & 1000 & & & & & & & \\
\hline 0.07 & 2000 & & & 1000 & 1 & & 1 & \\
\hline 0.10 & 3000 & & & & & & & \\
\hline 0.13 & 4000 & 1 & & 2000 & 1 & 1 & 2 & 1 \\
\hline 0.17 & 5000 & 8 & 6 & & & & 8 & 6 \\
\hline 0.20 & 6000 & 1 & & 3000 & 3 & 3 & 4 & 3 \\
\hline 0.23 & 7000 & 1 & 2 & & & & 1 & 2 \\
\hline 0.27 & 8000 & 2 & 4 & 4000 & 1 & 3 & 3 & 7 \\
\hline 0.30 & 9000 & & 1 & & & & & 1 \\
\hline 0.33 & 10000 & 14 & 30 & 5000 & 28 & 22 & 42 & 52 \\
\hline 0.37 & 11000 & 2 & 1 & & & & 2 & 1 \\
\hline 0.40 & 12000 & 4 & 9 & 6000 & 7 & 10 & 11 & 19 \\
\hline 0.43 & 13000 & 1 & 4 & & & & 1 & 4 \\
\hline 0.47 & 14000 & 1 & 4 & 7000 & 8 & 10 & 9 & 14 \\
\hline 0.50 & 15000 & 13 & 34 & & & & 13 & 34 \\
\hline 0.53 & 16000 & 2 & 6 & 8000 & 11 & 18 & 13 & 24 \\
\hline 0.57 & 17000 & 1 & 1 & & & & 1 & 1 \\
\hline 0.60 & 18000 & 4 & 10 & 9000 & 3 & 12 & 7 & 22 \\
\hline 0.63 & 19000 & & & & & & & \\
\hline 0.67 & 20000 & 6 & 20 & 10000 & 7 & 31 & 13 & 51 \\
\hline 0.70 & 21000 & & & & & & & \\
\hline 0.73 & 22000 & & 3 & 11000 & 1 & 7 & 1 & 10 \\
\hline 0.77 & 23000 & & 1 & & & & & 1 \\
\hline 0.80 & 24000 & & 1 & 12000 & & 5 & & 6 \\
\hline 0.83 & 25000 & 4 & 7 & & & & 4 & 7 \\
\hline 0.87 & 26000 & & 3 & 13000 & & 6 & & 9 \\
\hline 0.90 & 27000 & & & & & & & \\
\hline 0.93 & 28000 & & 2 & 14000 & & 3 & & 5 \\
\hline 0.97 & 29000 & & & & & & & \\
\hline 1.00 & 30000 & & & 15000 & & 3 & & 3 \\
\hline Total number & & 66 & 149 & & 73 & 134 & 139 & 283 \\
\hline
\end{tabular}


Table 4.9: Drivers of WTP to keep income private (Full Specification)

\begin{tabular}{|c|c|c|c|c|}
\hline & \multicolumn{4}{|c|}{ WTP to receive reward in private } \\
\hline & \multicolumn{2}{|c|}{ OLS } & \multicolumn{2}{|c|}{ FRM Marginal Effects } \\
\hline & $\begin{array}{c}\text { Female } \\
\text { (1) }\end{array}$ & $\begin{array}{l}\text { Male } \\
(2)\end{array}$ & $\begin{array}{c}\text { Female } \\
\text { (3) }\end{array}$ & $\begin{array}{l}\text { Male } \\
\text { (4) }\end{array}$ \\
\hline Equal input in decision making (0-10) & $\begin{array}{c}-0.0156 * * * \\
(0.0056)\end{array}$ & $\begin{array}{l}-0.0063 \\
(0.0077)\end{array}$ & $\begin{array}{c}-0.0155 * * * \\
(0.0053)\end{array}$ & $\begin{array}{c}-0.0064 \\
(0.0072)\end{array}$ \\
\hline Input in decision making (0-100) & $\begin{array}{c}0.0009 \\
(0.0012)\end{array}$ & $\begin{array}{c}0.0045^{* * * *} \\
(0.0015)\end{array}$ & $\begin{array}{c}0.0009 \\
(0.0011)\end{array}$ & $\begin{array}{c}0.0045 * * * \\
(0.0014)\end{array}$ \\
\hline Conflict and aggression (7-21) & $\begin{array}{c}-0.0130 * * * \\
(0.0045)\end{array}$ & $\begin{array}{l}-0.0078 \\
(0.0093)\end{array}$ & $\begin{array}{c}-0.0131 * * * \\
(0.0040)\end{array}$ & $\begin{array}{l}-0.0079 \\
(0.0090)\end{array}$ \\
\hline If member of a savings group $(0 / 1)$ & $\begin{array}{c}-0.0580 * * \\
(0.0279)\end{array}$ & $\begin{array}{c}0.0107 \\
(0.0270)\end{array}$ & $\begin{array}{c}-0.0582 * * \\
(0.0271)\end{array}$ & $\begin{array}{c}0.0111 \\
(0.0267)\end{array}$ \\
\hline Risk taking score quintiles (1-5) & $\begin{array}{c}0.0130 \\
(0.0095)\end{array}$ & $\begin{array}{c}0.0265^{* * * *} \\
(0.0098)\end{array}$ & $\begin{array}{c}0.0129 \\
(0.0094)\end{array}$ & $\begin{array}{c}0.0265^{* * * *} \\
(0.0086)\end{array}$ \\
\hline Age in years & $\begin{array}{l}-0.0029 \\
(0.0027)\end{array}$ & $\begin{array}{c}0.0011 \\
(0.0024)\end{array}$ & $\begin{array}{l}-0.0029 \\
(0.0027)\end{array}$ & $\begin{array}{c}0.0011 \\
(0.0025)\end{array}$ \\
\hline Educational attainment in years & $\begin{array}{l}-0.0032 \\
(0.0031)\end{array}$ & $\begin{array}{l}-0.0003 \\
(0.0029)\end{array}$ & $\begin{array}{l}-0.0032 \\
(0.0029)\end{array}$ & $\begin{array}{l}-0.0002 \\
(0.0029)\end{array}$ \\
\hline Works off-farm $(0 / 1)$ & $\begin{array}{c}0.0101 \\
(0.0267)\end{array}$ & $\begin{array}{l}0.0569 * \\
(0.0299)\end{array}$ & $\begin{array}{c}0.0100 \\
(0.0263)\end{array}$ & $\begin{array}{l}0.0572 * * \\
(0.0283)\end{array}$ \\
\hline Number of assets owned individually & $\begin{array}{c}0.0130 \\
(0.0222)\end{array}$ & $\begin{array}{l}-0.0305 \\
(0.0220)\end{array}$ & $\begin{array}{c}0.0130 \\
(0.0200)\end{array}$ & $\begin{array}{l}-0.0310 \\
(0.0203)\end{array}$ \\
\hline Number of children & $\begin{array}{l}-0.0012 \\
(0.0062)\end{array}$ & $\begin{array}{c}0.0100 \\
(0.0065)\end{array}$ & $\begin{array}{l}-0.0012 \\
(0.0066)\end{array}$ & $\begin{array}{c}0.0010 \\
(0.0062)\end{array}$ \\
\hline Age difference between partners & $\begin{array}{c}0.0010 \\
(0.0017)\end{array}$ & $\begin{array}{l}-0.0021 \\
(0.0020)\end{array}$ & $\begin{array}{c}0.0010 \\
(0.0017)\end{array}$ & $\begin{array}{l}-0.0022 \\
(0.0016)\end{array}$ \\
\hline Years of marriage & $\begin{array}{c}0.0010 \\
(0.0026)\end{array}$ & $\begin{array}{c}0.0007 \\
(0.00242)\end{array}$ & $\begin{array}{c}0.0010 \\
(0.0029)\end{array}$ & $\begin{array}{c}0.0006 \\
(0.0025)\end{array}$ \\
\hline Polygamous HH (0/1) & $\begin{array}{c}-0.0209 \\
(0.0283)\end{array}$ & $\begin{array}{c}0.0277 \\
(0.0335)\end{array}$ & $\begin{array}{c}-0.0209 \\
(0.0278)\end{array}$ & $\begin{array}{c}0.0276 \\
(0.0336)\end{array}$ \\
\hline Observations & 217 & 205 & 217 & 205 \\
\hline R-squared & 0.123 & 0.173 & & \\
\hline
\end{tabular}

Notes: Standard errors in parentheses. $* * * \mathrm{p}<0.01 * * \mathrm{p}<0.05 * \mathrm{p}<0.1$ 
Table 4.10: Intended and actual private versus household spending on female and male subsamples (restricted sample)

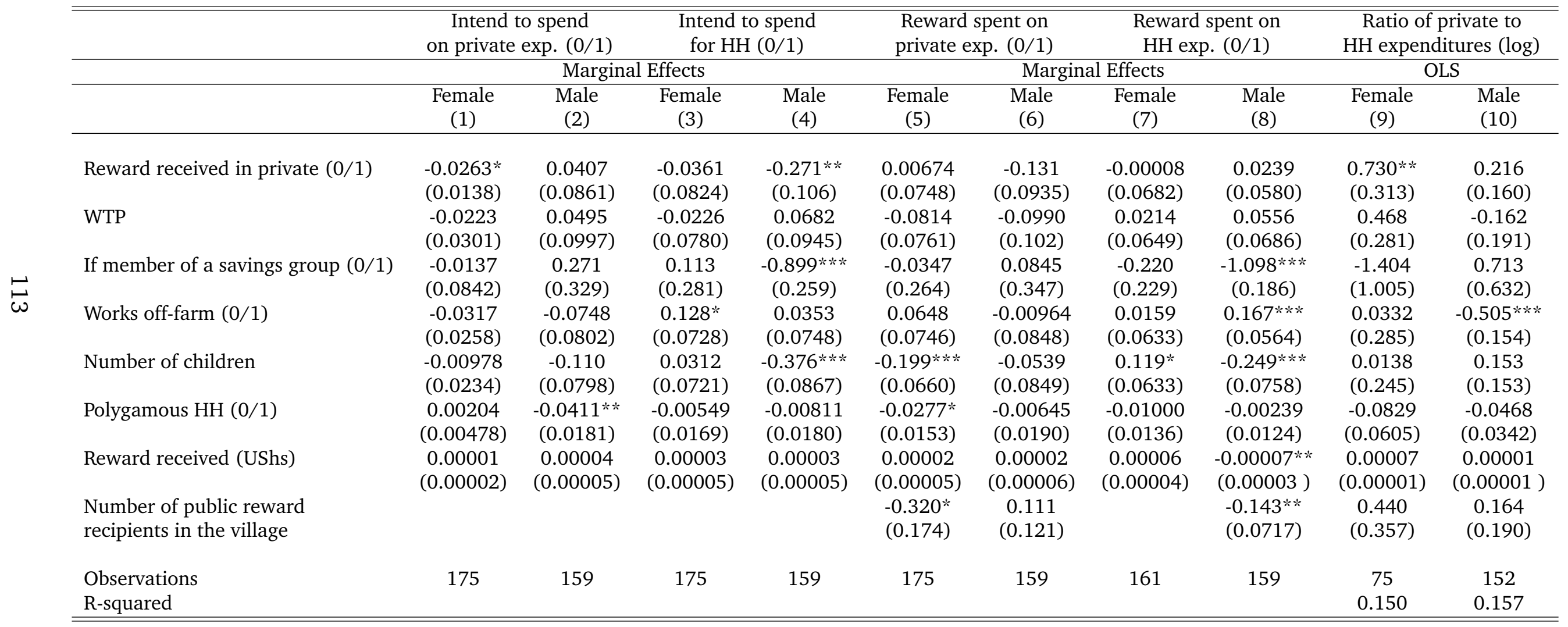

\footnotetext{
Notes: Restricted sample refers to participants who stated WTP between 0.33 and 0.67 inclusive. Standard errors in parentheses. $* * * p<0.01 * * p<0.05 * p<0.1$
} 
Table 4.11: Intended and actual private versus household spending on high- and low-reward subsamples (restricted sample)

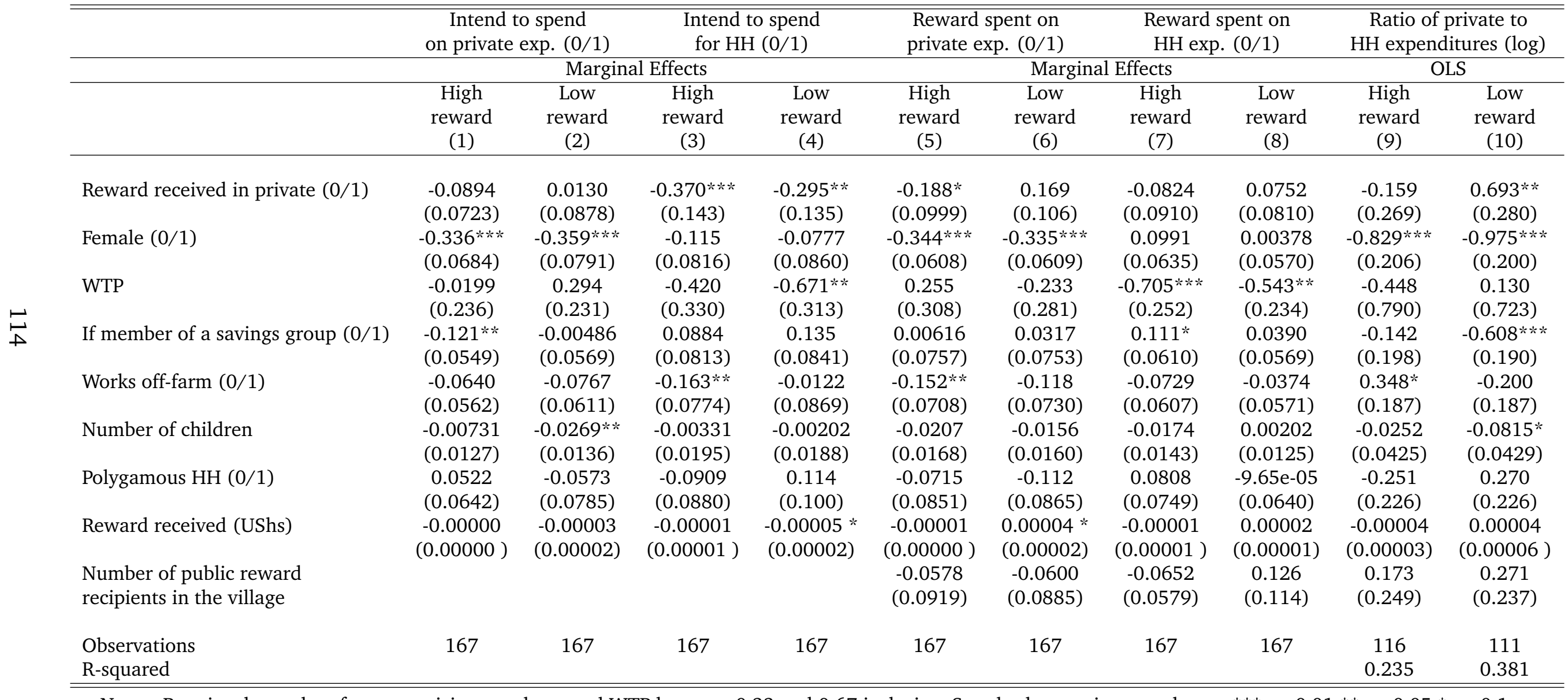

Notes: Restricted sample refers to participants who stated WTP between 0.33 and 0.67 inclusive. Standard errors in parentheses. ${ }^{* * *} \mathrm{p}<0.01 * * \mathrm{p}<0.05 * \mathrm{p}<0.1$ 
Table 4.12: Multicollinearity analysis for the model used to estimate drivers of WTP

\begin{tabular}{lcccc}
\hline \hline & \multicolumn{2}{c}{ Women } & \multicolumn{2}{c}{ Men } \\
\hline & VIF & 1/VIF & VIF & 1/VIF \\
\hline Years of marriage & 4.11 & 0.24 & 3.05 & 0.33 \\
Age in years & 3.70 & 0.27 & 2.91 & 0.34 \\
Input in decision making (0-100) & 1.53 & 0.65 & 2.58 & 0.39 \\
Educational attainment in years & 1.49 & 0.67 & 1.26 & 0.79 \\
Equal input in decision making (0-10) & 1.43 & 0.70 & 2.24 & 0.45 \\
Number of assets owned individually & 1.25 & 0.80 & 1.15 & 0.87 \\
Number of children & 1.23 & 0.81 & 1.21 & 0.83 \\
Risk taking score quintiles (1-5) & 1.22 & 0.82 & 1.18 & 0.85 \\
Works off-farm (0/1) & 1.21 & 0.83 & 1.37 & 0.73 \\
Age difference between partners & 1.19 & 0.84 & 1.12 & 0.89 \\
Conflict and aggression (7-21) & 1.17 & 0.86 & 1.19 & 0.84 \\
Polygamous HH (0/1) & 1.10 & 0.91 & 1.07 & 0.93 \\
Whether member in a savings group (0/1) & 1.09 & 0.91 & 1.15 & 0.87 \\
Mean VIF & 1.67 & & 1.65 & \\
\hline \hline
\end{tabular}

Notes: VIF refers to variance inflation factor. 1/VIF is interpreted as tolerance. Tolerance below 0.1 is a sign of multicollinearity in the model.

Table 4.13: Correlation between the items in the aggression index

\begin{tabular}{lcc}
\hline \hline & \multicolumn{2}{c}{ Female participants } \\
\hline & $\begin{array}{c}\text { Difficulty in resolving } \\
\text { conflict }(1-7)\end{array}$ & $\begin{array}{c}\text { Verbal aggression } \\
(1-7)\end{array}$ \\
\hline Verbal aggression (1-7) & $0.618^{* * * *}$ & $0.656 * * *$ \\
Physical aggression (1-7) & $0.638^{* * *}$ & 0.1 \\
\hline \hline
\end{tabular}




\section{Chapter 5}

\section{Conclusion}

This chapter discusses the policy implications derived from this dissertation, outlines the shortcomings of the essays, and mentions a few ideas for future research.

\subsection{Synopsis of findings and the ensuing policy im- plications}

Agricultural transformation encompasses, among other things, use of better technologies, increased productivity, value upgrading, higher participation in global value chains, and exploiting the opportunities of export of high-value products. There are, however, several barriers to such transformation. Information is one commonly identified constraint on adoption of improved technologies. Most developing countries rely on extension workers to deliver technical information to farmers in the path of agricultural transformation and growth. Yet, evidence on the effectiveness of extension services is inconclusive. To contribute to this agenda, the first essay evaluates the effects of information communicated by different communicators in extension using a randomised field experiment for identification. Keeping information content identical, the communicator varied across treatments. Information was communicated by an extension worker alone (T1), by an extension worker and a peer farmer (T2), or by an extension worker and a high-status market actor (T3). We find larger effects on improved harvest practices if the extension worker is supported by a peer farmer while farmers who receive information both from an extension worker and also a market actor participate more in high-value markets. Hence, we document a case wherein who communicates the information influences what technology is adopted. We propose that the differences in adoption occur due to persuasive effectiveness of the communicator based on his/her competence in respective topics and trustworthiness attributes. Additionally, we show that quality upgrading and participation in high-value markets together lead to adoption and higher coffee revenues for primary producers, albeit to a small extent. 
The policy implications drawn based on this essay are as follows. First, addressing informational inefficiencies in a comprehensive way, regarding both product quality and high-value market participation which together lead to higher revenues, is critical. Notice that this strategy fits particularly well with the inclusive value chain development efforts outlined in the introduction of the dissertation. In particular, not only addressing a particular constraint, coffee quality, but coupling it with high-value market participation, this research demonstrates a good example of value chain development efforts eventually leading to value-addition and higher participation in high-value export markets. Second, it is important to employ an effective communicator in delivering extension services. This may depend on the type of information and vary according to contextual factors. Hence, tailoring or augmenting the traditional extension services, such as making use of effective peer farmers or other value chain actors such as the buyer, could increase adoption of better technologies and high-value market participation eventually improving the welfare of small-scale producers in developing countries.

The second essay considers the role of partial processing of Arabica coffee by farming households into parchment as a value-adding activity. We base our hypothesis that parchment production would yield lower revenues than fresh cherry sales on the concept of the "market for lemons" proposed by Akerlof (1970). Akerlof outlines how a market for a product which is associated with quality uncertainty and asymmetric information between the buyer and the seller could generate a case in which quality and prices of the products traded decrease. Indeed, results show that processing fresh coffee cherries to produce a more complex coffee product reduces coffee revenues and profits earned. These findings are in line with the conclusions of Gibbon and Ponte (2005), Ponte and Ewert (2009), and Vicol et al. (2018) that the efforts for value addition do not always pay off for producers. In the light of these results we provide insights into the drivers of parchment production. Our analysis indicates that quality of fresh coffee produce is a determining factor of parchment production for a number of growers. Growers with lower-quality farms, such as those from lower altitudes and more affected by pest and diseases, engage with parchment to a larger extent. Similarly, growers who hire labour for picking produce higher levels of parchment. This finding suggests, among others, presence of principal-agent problems. Hired pickers are paid based on quantity and not quality reducing the incentives to invest time in harvesting high quality coffee. Our analysis also indicates presence of a small group farmers, with higher capacity to determine coffee quality (knowledge and cognitive ability), that take advantage of the quality uncertainty in the parchment to process 
lower quality cherries and sell the low-quality coffee parchment nonetheless. This effectively causes relatively high-quality parchment producers to subsidise lowquality parchment producers, in line with the arguments of Miyazaki (1977) and Wilson (1977).

Several policy recommendations follow based on these findings. Firstly, promotion of value upgrading through processing activities in agri-food markets should be undertaken with care because activities aiming at moving growers up the value chain may have adverse effects on smallholder livelihoods. It is thus critical to incorporate relevant characteristics of the supply chain, such as quality assurance, into efforts of value chain development for profitable and sustainable agricultural transformation. Secondly and relatedly, our findings show that quality is a determining factor in participating in low-quality low-price parchment markets. Producing higher quality cherries would consequently reduce participation in parchment markets. Quality of coffee can be improved with better care of gardens reducing pest and disease damage. Additionally, improved harvest practices, outlined in the first essay, increase the quality of cherries harvested to a large extent. In the light of the growing demand for high-quality coffee and excess supply of low-quality coffee in the world, our results suggest a major role for extension to improve the agricultural practices to increase coffee quality in the region. However, this would only be viable and sustainable under quality assurance and if monetary incentives for higher quality are in place. Efforts should be made for a more efficient value chain that rewards quality, and incentives should be aligned across the actors in the value chain including the farm labourers who harvest coffee. For instance, a value chain intervention which pays for high-quality coffee through using an effective and objective quality measurement tool could help to this end.

At a higher level, we recommend the policy makers to adopt a larger scale strategy to produce high-quality coffee to transform the coffee sector for the better. For instance, Costa Rica adopted a nation-wide policy and, taking necessary actions, established itself as a producer of high-quality coffee. Primary producers in Costa Rica do not process coffee cherries and must instead sell their produce to cooperatives for processing and cooperatives are heavily monitored to ensure quality standards (Wollni and Zeller, 2007). A similar strategy has been adopted in Rwanda. Producers are encouraged to market their cherries fresh and cooperatives are the main processors of coffee cherries (Mujawamariya et al., 2013). Given that parchment market is characterised by a market for lemons, producers 
should be incentivised to increase the quality of their coffee and market their cherries to participate in high value markets and the whole value chain could thrive. Tighter regulations for processing coffee are thus recommended. Lastly, based on the anecdotal evidence we have that market may be saturated in peak season and buyers may stop buying coffee. This suggest a role for coffee exporters and authorities regarding investment in increasing the capacity of processing facilities. It also represents a lucrative investment opportunity for the private sector. Such efforts would enable thousands of smallholder producers to market their cherries at competitive prices and participate in higher value coffee markets.

The last essay of this dissertation is a reminder of the cruciality of household dynamics to welfare improvements. Whilst value chain development may be an effective strategy to increase income, its effects on poverty depends largely on how resources are allocated within the producer households. Higher household income likely facilitates investment in more profitable economic activities, health, and education, which eventually alleviate poverty. However, household resources may not always be spent in the best way possible, in particular, in the context of differing preferences and non-cooperation between the male and female household heads.

The third essay is based on an experiment in which willingness to pay of either female or male household head to receive a windfall income in private from their partner was elicited. Willingness to pay to hide income allows for quantification of potential efficiency losses in the household since individuals trade-off household income for control over that income. Household heads were willing to give out, on average, 50 percent of the reward to keep it secret indicating substantial efficiency losses in the household - evidence against the Pareto efficiency that the unitary models conclude and collective household models postulate. There are no large differences in the stated WTP to hide income across genders but drivers of the WTP to hide income differ. Equality in say in various household decisions is negatively associated with WTP of women to hide income. Men's WTP and associated inefficiency, however, increases in the input they have in household decisions indicating that a larger say for women in these households could improve efficiency. Our analysis also shows that private reward recipients are less likely to have the intention to spend the reward for their household and more likely for private expenses compared to public reward recipients. This effect is particularly strong and significant for men. In the week following the experiment, private spending in relation to household spending increases as a result of receiving the 
reward in private both for women and men.

Whilst women provide much of the coffee labour, it is men who market the coffee and have control over sales revenues. Hence, it is likely that coffee revenues may not always fully benefit other members of the household than the one who holds them. Our study shows that men hide income from their wives to use it for their individual spending. The policy recommendation that ensues from this research is that alternative forms of (coffee) payments can be developed within the value chain development efforts in a way that benefits women. For instance, many cash transfer programs target women all around the world based on the idea that women spend more for their household and children. Another policy-relevant finding of this study is that women who are a member of savings group tend to state a lower WTP and are also less likely to allocate resources towards private spending and more likely to use it for their household. There is thus scope for savings groups and financial inclusion interventions to reduce the tendency to hide income and associated inefficiency losses, and to increase the tendency to save and possibly shift household resources towards better allocations. One potential channel through which savings group membership affect income hiding and spending decisions is altered household norms over how to treat household income. Savings and financial holdings (as women's resources) improve women's capabilities and is a potential pathway towards women's empowerment and achieving gender equality (Kabeer, 1999). Given that women's empowerment is also associated with higher efficiency in the household, savings interventions might further help change allocation of resources for the better. More control over household resources for women is associated with benefit nutrition, health, and education of children in the household contributing to poverty alleviation.

\subsection{Limitations and scope for further research}

This dissertation is based on data collected from smallholder coffee growers in the Mount Elgon region of Uganda. As mentioned earlier, the Arabica coffee sector in Uganda is very suitable to study topics, such as information constraints on coffee quality and high-value markets, value chain development activities, and profitability of upgrading. Our findings and policy implications are also relevant for a number of agri-food value chains (e.g. cocoa and vanilla) originating in developing countries and with quality uncertainty issues present at different stages of the value chain. Social norms and women's role in the area are also similar to those in many other developing countries. 
Whilst this dissertation is based on rigorous empirical analysis and provide robust evidence, some limitations remain. All three essays in this dissertation rely on survey data collected using recall methods. Recall data are associated with recall bias induced by inaccurate recollection of events by the respondent. Despite that research shows little evidence of recall bias for agricultural production it is a factor to consider. In addition, social desirability or demand effects, i.e. changes in responses by respondents regarding what constitutes appropriate behaviour or what is expected of her/him, are key concerns with experimental studies. We tried to reduce such effects by adjusting the order of the questions in the surveys, and using different teams for data collections and the intervention. We paid special attention to training the field assistants on such issues and instructed them to remain neutral and non-judgemental throughout the interview. For the last essay which focuses on household decision-making and gender issues, each participant was interviewed by a same-sex field assistant to encourage unbiased responses to the extent possible.

The first essay builds on a randomised experiment which is a powerful solution to the evaluation problem - the fact that we can never observe the same individual with and without being exposed to the treatment at one point in time (Angrist and Pischke, 2009; Duflo et al., 2007). Despite the random allocation of treatment to farmer groups, the treatment and control groups did not turn out to be balanced on one of the key outcome variables, which undermines the key strength of the randomised experiment. However, we were able to use differences-in-differences method to circumvent this problem. Additionally, the imperfect compliance experienced (low take-up in the treatment group and contamination in the control group), reduced the power of the experiment to a large extent. Contamination and information spillovers to the control group may represent a threat to internal validity of the experiment. We control for information spillovers in a simplistic way, but do not explicitly study spillovers or network effects. It is beyond the scope of this essay, yet, with the social network data collected, I plan to study the coffee (social) networks and, for instance, their role in information diffusion, and how they affect outcomes related to coffee quality and high-value market participation.

This essay pays particular attention to use of different communicators to remove informational constraints on adoption. Further research should shed more light on which other extension modalities are effective in inducing adoption of welfareimproving practices and, more critically, on the mechanisms that channel the effects. A survey tool can be developed to measure (perceived) persuasive effec- 
tiveness of communicators which can also be applied broadly to identify effective communicators for more effective information diffusion. Additionally, rigorously evaluating the long-term effects of such value chain interventions are rare but would provide several insights into how to alter and adapt further interventions and policies for the better.

A potential limitation of the second essay is that it is based on observational crosssectional data and may not account for possible selection bias arising from the inherent differences between farmers who produce parchment and who do not. With the rich baseline data collected, some of those differences are controlled for. More critically, however, we employ an instrumental variable approach to deal with the selection bias. One should nonetheless carefully interpret the results as this method relies heavily on the quality of the instrument. Alternatively, an analysis of the effects and drivers of parchment production without suffering from selection bias could be conducted within a randomised controlled trial. However, it is simply impractical to randomly assign parchment production to certain farmers. Panel data methods can perhaps be used to deal with selection bias as well.

This essay draws upon a couple important economic concepts, such as quality uncertainty, asymmetric information and adverse selection. As an extension, I also plan to explicitly test the existence and document the costs of adverse selection into parchment markets making use of a theoretical framework. Quality issues are central to the efficiency of the coffee value chain in particular at the upstream segments. Hence, it would be interesting to evaluate the introduction of objective and efficient quality measurement tools, and how such an intervention improves the efficiency of the coffee value chain along with the welfare of a large number of farmers and farm labourers.

There are a few points to keep in mind regarding the last essay as well. First, the experiment is based on a relatively small sample despite that the number of observations per treatment is within the usual levels used by experimental studies. However, for one outcome variable of interest we have several zeros complicating the subgroup analyses due to low power. Secondly, the randomisation tool we use (generated within the BDM mechanism) is only random conditional on stated WTP. We address this issue by controlling for WTP in the regressions. Thirdly, we are unable to account for the income effect arising from inherent differences between the size of private and public rewards. To assess the extent to which the latter two affect the results, a similar study can be conducted wherein equal amount of rewards are randomly assigned to the participants. 


\section{Appendix A}

\section{Who communicates the information influences what technology is adopted}

\section{A.1 Harvest Quality Score}

Harvest quality score is constructed using 3 variables to capture harvest quality. The first two capture the two dimensions of improved harvest practices, such as delaying harvest sufficiently to harvest ripe cherries, and harvesting selectively and frequently. The third one used in the construct is self-reported harvest quality. In particular, the harvest quality score is constructed using the following questions:

1- How does the time you waited before you harvested your cherries in the last season compare with the season before (if harvest was delayed more compared to the 2017 season)? If yes, another question follows: Why did you delay harvest more than you delayed in the last season? (1 point if they mention heard that it is better for qualityänd if they mention "so that they ripen well for high quality")

2- Calculated labour days for picking coffee per ton of coffee harvested in the last season 2018 (average number of pickers times the number of labour days divided by harvest in tons)

3- Can you estimate the share of underripe, overripe, dried, and damaged (lowquality) cherries in a typical harvest basket? Answers are recorded in 5 percentage point brackets (e.g. 0-4.99 percent, 5-9.99 percent etc.) and transformed to capture the share of ripe (high-quality) cherries. Each of the variables are scaled down to range from $0-1$ to be included in the index. The sum of these $3(0-1)$ variables builds the harvest quality score variable (0-3). No weight applied. 


\section{Appendix B}

\section{Paying more to make less: value degrading in the cof- fee value chain in eastern Uganda}

\section{Coffee quality knowledge questions:}

1-5) Can you please rate the quality of cherries shown in the picture?
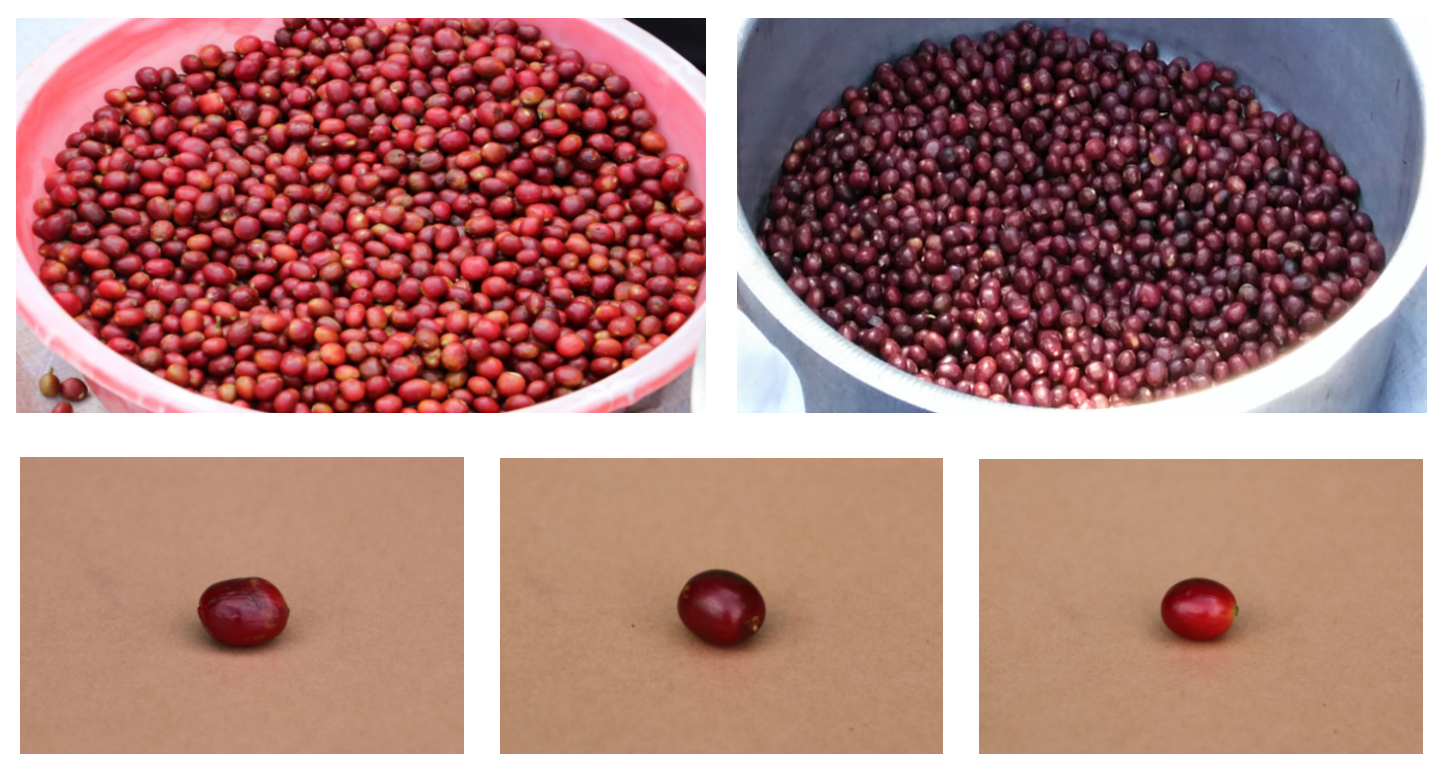

6) Ideally, how often should cherries be picked from the tree in the peak season?

7) Ideally, how long after picking cherries should they be pulped?

8) Ideally, what should be the moisture level in percentages at time of selling parchment?

9) How important do you think is maturity of cherries while harvesting for quality?

10) How important do you think is no damage by pests and pest management for quality?

1 point for each correct answer to the questions 1-10. 


\section{Cognitive ability test questions:}

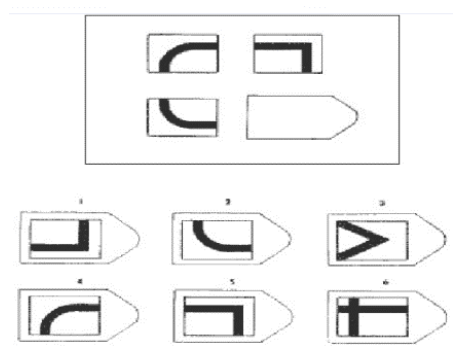

1a)
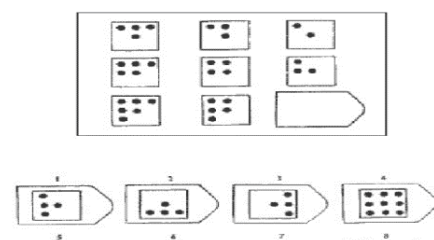

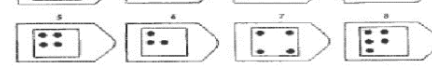

1c)

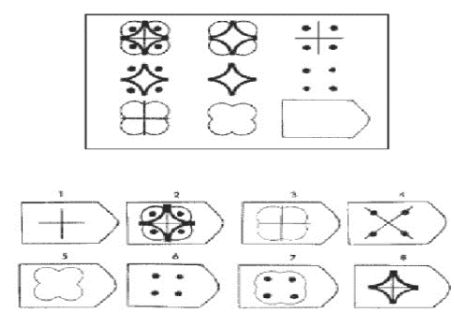

1e)

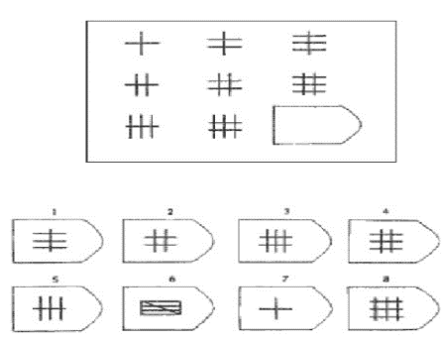

1b)
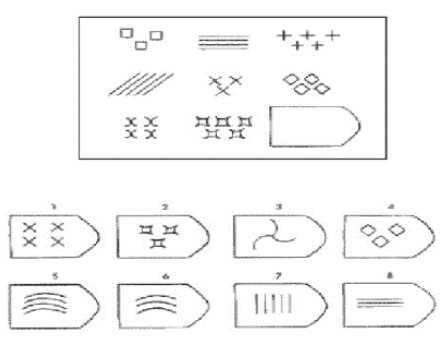

1d)

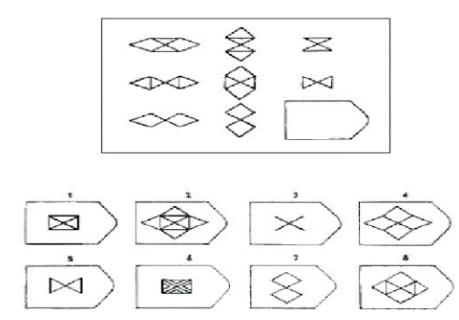

1f)

2a) $2+5$ ?

2b) $8+9=$ ?

2c) $23+14$ ?

2d) $43-9=$ ?

2e) $1 \times 0=$ ?

2f) $5 \times 3=$ ?

2g) $6 \times 7=$ ?

2h) $11 \times 9=$ ?

2i) $12 \times 12=$ ?

2j) $175 / 25=$ ?

1 point given for each correct answer to questions 1c-1e; 2 points for correctly answering question $1 \mathrm{f} ; 0.25$ point given for each correct answer to questions $2 \mathrm{a}-2 \mathrm{~d}$; 0.5 point given for each correct answer to questions; $2 \mathrm{e}-2 \mathrm{~h}$ given point for each correct answer to questions $2 \mathrm{i}-2 \mathrm{j}$. 


\section{Appendix C}

\section{Inefficiency in the household: a gendered analysis of willingness to pay to hide income from spouses in ru- ral Uganda}

\section{Experimental Instructions}

It is critical that you ensure the participants responses are completely anonymous to their spouse. This means you should ensure the respondent is interviewed in a separate area where partners cannot see or hear each other and with no other adults or older children present (i.e. only infants or very young children).

Good morning/afternoon, we are here today to go over a short study. Details of this study are provided in this participant information sheet.

HAND THEM THE BDM PARTICIPANT INFORMATION.

I'll now read through this participant information sheet with you.

READ THROUGH THE SHEET WITH THEM AND CHECK UNDERSTANDING AS YOU GO.

Now, before we start, I need to ask about your agreement in participating in this study.

HAND THE CONSENT FORM.

I'll now read through this consent form with you.

READ THROUGH THE CONSENT FORM WITH THEM CHECKING UNDERSTANDING AS YOU GO.

OBTAIN AGREEMENT BY ASKING THEM TO CLICK 'YES' ON THE TAB IF THEY AGREE. 
IF THE PARTICIPANT IS NOT WILLING THEN YOU WILL HAVE TO MOVE TO YOUR NEXT HOUSEHOLD. THANK THEM FOR THEIR TIME.

\section{IF THE PARTICIPANT IS WILLING YOU MAY BEGIN THE STUDY.}

Ok, now we will begin the first of two tasks. You have been randomly selected to have the opportunity to participate in a task where you can earn some money, either privately or known by your partner. Your answers today are COMPLETELY anonymous. If you earn your endowment privately no-one here except you and me will know how much you earnt and you will be free to use your money as you wish. If you earn your endowment in public we will give it to you at the end of our visit today in the presence of your partner.

So, the main task we will do today is about earning money privately compared to earning money that your partner will know about.

Do you understand?

I'll now provide you some more details.

In order to keep the reward to yourself your reward may be reduced. Specifically, we want to know what it is worth for you to receive the money privately versus in front of your spouse.

To do this you should state how much, out of the 15,000/30,000 shilling reward, you are willing to lose in order to keep the reward itself secret. You then draw a random amount from this bag (show them).

There are then two possible outcomes:

1-If your stated willingness to pay is LOWER than the randomly drawn value then you will not pay anything but your reward will be given to you in front of your partner at the end of our meeting today.

2-If your stated willingness to pay is GREATER THAN OR EQUAL TO the randomly drawn value then you will receive the reward right now, and in private, but minus the randomly drawn value.

So imagine you stated '10,000 shillings' as your value to keep the reward private. 
If you drew a value of 5,000 shillings then you would receive the reward amount right now, in private, minus 5,000 shillings.

If you drew a value of 11,000 shillings you would not pay anything and receive the full reward value but in front of your partner at the end of our meeting today.

There are two key things you need to remember here:

Firstly, the higher your willingness to pay statement is, the more likely you are to receive your reward in private.

Secondly, if you are to keep the reward private you will ONLY pay the randomly drawn value, not your stated value. So you can feel free to state your true willingness to pay to keep the reward payment knowing that you may actually pay less than that to keep it private.

YOU WILL RUN TWO OR MORE PRACTICE ROUNDS UNTIL THE SUBJECT UNDERSTANDS THE TASK THEY ARE EXPECTED TO PERFORM. ONCE THEY HAVE UNDERSTOOD YOU ASK THEM TO MAKE A DECISION FOR REAL.

Let's run a few practice rounds first to help you understand.

First, you state the maximum amount out of the reward amount that you are willing to lose in order to receive the reward privately instead of in front of your spouse.

So think of an amount between 0 and 15,000 (or 30,000) shillings that you would be willing to pay to keep this money private.

IT NEEDS TO BE IN 1,000 SHILLING INCREMENTS. SO IF THEY CHOOSE 500 SHILLINGS FOR EXAMPLE YOU CAN TELL THEM THEY NEED TO CHOOSE EITHER 0 OR 1,000 OR SOME OTHER NUMBER.

IF THEY CHOOSE 'O' ENCOURAGE THEM TO 'PRACTICE' BY CHOOSING A POSITIVE AMOUNT (the money will remain private and they can spend the money as they like if they participate in the BDM game).

Now you draw a random value between 1000 shillings and 15,000/30,000 shillings from this bag. 
GET THEM TO DRAW A TOKEN FROM THE BAG. NOTE THE VALUE AND STATE IT BACK TO THEM ENSURING THEY CAN SEE WHAT VALUE THEY DREW.

What is the number on the token? REPEAT THE NUMBER BACK TO THEM.

So, remember, you stated STATE THEIR NUMBER, is that correct?

IF THEIR STATED VALUE IS LOWER THAN THE TOKEN NUMBER:

Your stated value STATED VALUE is lower than the token number NUMBER ON TOKEN . Do you remember what this means for you and the reward?

LET THEM TRY TO ANSWER. IF THEY STRUGGLE YOU CAN HINT AT THE RESPONSE (I.E. THEY WILL GET THE FULL REWARD AT THE END OF THE SESSIONS IN FRONT OF THEIR PARTNER SO THAT IT IS NOT SECRET).

IF THEIR STATED VALUE IS GREATER THAN OR EQUAL TO THE TOKEN NUMBER:

Your stated value STATED VALUE is greater than or equal to the token number NUMBER ON TOKEN . Do you remember what this means for you and the reward?

LET THEM TRY TO ANSWER. IF THEY STRUGGLE YOU CAN HINT AT THE RESPONSE (I.E. THEY WILL PAY THE NUMBER ON THE TOKEN OUT OF THE REWARD AMOUNT AND RECEIVE THE REMAINDER IMMEDIATELY IN SECRET).

Do you understand?

YOU NEED TO ASSESS THEIR UNDERSTANDING AND BE SURE THE RESPONDENT UNDERSTANDS. BE READY TO RUN THE PRACTICE ROUND SEVERAL TIMES AND GETTING THEM TO ANSWER BEFORE YOU RUN IT FOR REAL.

Ok, now we will run the task for real. Remember, there is no wrong answer here and your responses will be kept completely private - state only what you think it is worth paying to receive your reward in private so no one else knows you received it.

Are you ready?

What value would you be, at most, willing to pay out of your reward to receive it in private? 
NOTE THE VALUE IN THE DATA RECORDING TOOL AND WRITE IT DOWN ON YOUR RECORDING SHEET FOR THEM TO SEE.

You stated (VALUE), is that correct?

Ok, now we'll get you to choose a token from the bag.

SHAKE THE BAG AGAIN WITH ALL THE TOKENS INSIDE. THEN GET THEM TO SELECT A TOKEN WITHOUT LOOKING IN THE BAG. ENSURE THEY ONLY SELECT ONE TOKEN.

OBSERVE THE NUMBER ON THE TOKEN AND STATE IT TO THE PARTICIPANT:

The value on the token is (TOKEN VALUE).

ENTER THE TOKEN VALUE INTO THE DATA RECORDING TOOL.

IF THEIR STATED VALUE IS LOWER THAN THE TOKEN NUMBER:

Your stated value STATED VALUE is lower than the token number NUMBER ON TOKEN.

This means you will receive the full reward but I will give it to you once we have finished this task and it will be presented to you in front of your partner. So you will receive the reward in public.

ENTER THE FINAL REWARD AMOUNT INTO THE DATA RECORDING TOOL.

IF THEIR STATED VALUE IS GREATER THAN OR EQUAL TO THE TOKEN NUMBER:

Your stated value STATED VALUE is greater than or equal to the token number NUMBER ON TOKEN. This means you will receive the reward from me now in private, minus the token value, and no one else you know will know that you received money from me today. You can choose what you want to do with it.

Your reward is (VALUE OF FINAL REWARD)

ENTER THE FINAL REWARD AMOUNT INTO THE DATA RECORDING TOOL.

GIVE THE PARTICIPANT THE FINAL REWARD AMOUNT. 
You can hold onto this while we do the second and last task for today. MOVE ON TO THE SURVEY QUESTIONS.

NOTE: IF THE STATED VALUE IS LOWER THAN THE TOKEN VALUE, REMEMBER TO GIVE THE REWARD TO THE PARTICIPANT ONCE YOU HAVE FINISHED BOTH TASKS AND REUNITED THE HOUSEHOLD HEADS. STATE THE FOLLOWING TO THE PARTNER OF THE PARTICIPANT:

"We are giving your partner this reward of 15,000/30,000 shillings based on their answers to questions in the survey. We have randomly selected some participants to receive this reward and your partner happens to be one of those people today". 


\section{Bibliography}

Abadie, A. (2005). Semiparametric difference-in-differences estimators. The Review of Economic Studies, 72(1):1-19.

Aker, J. C. (2011). Dial A for agriculture: a review of information and communication technologies for agricultural extension in developing countries. Agricultural Economics, 42(6):631-647.

Aker, J. C. and Ksoll, C. (2016). Can mobile phones improve agricultural outcomes? Evidence from a randomized experiment in Niger. Food Policy, 60:4451.

Akerlof, G. (1970). The Market for Lemons: Quality Uncertainty and the Market Mechanism. The Quarterly Journal of Economics, 84(3):488-500.

Akroyd, S. and Smith, L. (2007). Review of public spending to agriculture. Main study \& Country Case-Studies.

Almas, I., Armand, A., Attanasio, O., and Carneiro, P. (2018). Measuring and changing control: Women's empowerment and targeted transfers. The Economic Journal, 128(612):609-639.

Almlund, M., Duckworth, A. L., Heckman, J. J., Kautz, T., Hanushek, E. A., Machin, S., and Woessmann, L. (2011). Handbook of the Economics of Education.

Ameyu, M. A. (2017). Influence of harvesting and postharvest processing methods on the quality of Arabica coffee (Coffea arabica L.) in Eastern Ethiopia. ISABB Journal of Food and Agricultural Sciences, 7(1):1-9.

Anderson, S. and Baland, J. M. (2002). The economics of roscas and intrahousehold resource allocation. The Quarterly Journal of Economics, 117(3):963-995.

Angrist, J. D. and Pischke, J. S. (2009). Instrumental variables in action: sometimes you get what you need. Mostly Harmless Econometrics: An Empiricist's Companion, pages 113-218.

Ashraf, N., Field, E., and Lee, J. (2014). Household bargaining and excess fertility: an experimental study in Zambia. American Economic Review, 104(7):22102237. 
Ashraf, N., Giné, X., and Karlan, D. (2009). Finding missing markets (and a disturbing epilogue): Evidence from an export crop adoption and marketing intervention in Kenya. American Journal of Agricultural Economics, 91(4):973-990.

Baffes, J. (2006). Restructuring Uganda's Coffee Industry: Why going back to basics matters. Development Policy Review, 24(4):413-436.

Bandiera, O. and Rasul, I. (2006). Social networks and technology adoption in northern Mozambique. The Economic Journal, 116(514):869-902.

Banerjee, A. V. and Duflo, E. (2007). The economic lives of the poor. Journal of Economic Perspectives, 21(1):141-168.

Bardhan, P. and Udry, C. (1999). Development Microeconomics. OUP Oxford.

Barham, B. L. and Weber, J. G. (2012). The economic sustainability of certified coffee: recent evidence from Mexico and Peru. World Development, 40(6):12691279 .

Barrett, C. B., Bachke, M. E., Bellemare, M. F., Michelson, H. C., Narayanan, S., and Walker, T. F. (2012). Smallholder participation in contract farming: comparative evidence from five countries. World Development, 40(4):715-730.

Beaman, L., BenYishay, A., Magruder, J., and Mobarak, A. M. (2018). Can network theory-based targeting increase technology adoption? National Bureau of Economic Research.

Becker, G. M., DeGroot, M. H., and Marschak, J. (1964). Measuring utility by a single-response sequential method. Behavioral Science, 9(3):226-232.

Becker, G. S. (1974). On the Relevance of the New Economics of the Family. The American Economic Review, 64(2):317-319.

Bellemare, M. F. and Barrett, C. B. (2006). An ordered Tobit model of market participation: Evidence from Kenya and Ethiopia. American Journal of Agricultural Economics, 88(2):324-337.

Beltramo, T., Blalock, G., Levine, D. I., and Simons, A. M. (2015). The effect of marketing messages and payment over time on willingness to pay for fuelefficient cookstoves. Journal of Economic Behavior \& Organization, 118:333345.

BenYishay, A. and Mobarak, A. (2019). Social learning and incentives for experimentation and communication. The Review of Economic Studies, 86(3):9761009. 
Besley, T. and Case, A. (1994). Diffusion as a learning process: Evidence from HYV cotton. Princeton University.

Beuchelt, T. D. and Zeller, M. (2011). Profits and poverty: Certification's troubled link for Nicaragua's organic and fairtrade coffee producers. Ecological Economics, 70(7):1316-1324.

Birkhaeuser, D., Evenson, R. E., and Feder, G. (1991). The economic impact of agricultural extension: A review. Economic Development and Cultural Change, 39(3):607-650.

Bobonis, G. J. (2009). Is the allocation of resources within the household efficient? New evidence from a randomized experiment. Journal of Political Economy, 117(3):453-503.

Bobonis, G. J., Perez Castro, R., and Morales, J. S. (2015). Conditional cash transfers for women and spousal violence: evidence of the long-term relationship from the Oportunidades program in Rural Mexico. IDB Working Paper Series.

Boltz, M., Marazyan, K., and Villar, P. (2019). Income hiding and informal redistribution: A lab-in-the-field experiment in Senegal. Journal of Development Economics, 137:78-92.

Bradbury, T. N., Fincham, F. D., and Beach, S. R. (2000). Research on the nature and determinants of marital satisfaction: A decade in review. Journal of Marriage and Family, 62(4):964-980.

Bridle, L., Magruder, J., McIntosh, C., and Suri, T. (2020). Experimental Insights on the Constraints to Agricultural Technology Adoption.

Browning, M. and Chiappori, P. A. (1998). Efficient intra-household allocations: A general characterization and empirical tests. Econometrica, pages 1241-1278.

Browning, M., Chiappori, P. A., and Weiss, Y. (2014). Economics of the Family. Cambridge University Press.

Bruhn, M. and McKenzie, D. (2009). In pursuit of balance: Randomization in practice in development field experiments. American Economic Journal: Applied Economics, 1(4):200-232.

Burke, W. J. (2009). Fitting and interpreting Cragg's tobit alternative using Stata. The Stata Journal, 9(4):584-592. 
Burke, W. J. (2019). Evidence against Imposing Restrictions on Hurdle Models as a Test for Simultaneous versus Sequential Decision Making. American Journal of Agricultural Economics, 101(5):1473-1481.

Campos, A., Villani, C., Davis, B., and Takagi, M. (2018). Ending extreme poverty in rural areas - Sustaining livelihoods to leave no one behind. FAO.

Carril, A. (2017). RANDTREAT: Stata module to randomly assign treatments uneven treatments and deal with misfits.

Castilla, C. (2015). Trust and reciprocity between spouses in India. American Economic Review, 105(5):621-624.

Castilla, C. and Walker, T. (2012). Gender Roles and Intra-Household Allocation. Unpublished.

Castilla, C. and Walker, T. (2013). Is ignorance bliss? The effect of asymmetric information between spouses on intra-household allocations. American Economic Review, 103(3):263-268.

Charness, G. and Dufwenberg, M. (2006). Promises and partnership. Econometrica, 74(6):1579-1601.

Chen, J. J. (2006). Migration and imperfect monitoring: implications for intrahousehold allocation. American Economic Review, 96(2):227-231.

Chen, Z. and Woolley, F. (2001). A Cournot-Nash model of family decision making. The Economic Journal, 111(474):722-748.

Chiappori, P. A. (1992). Collective labor supply and welfare. Journal of Political Economy, 100(3):437-467.

Chiputwa, B., Spielman, D. J., and Qaim, M. (2015). Food standards, certification, and poverty among coffee farmers in Uganda. World Development, 66:400-412.

Clingingsmith, D., Khwaja, A. I., and Kremer, M. (2009). Estimating the impact of the Hajj: religion and tolerance in Islam's global gathering. The Quarterly Journal of Economics, 124(3):1133-1170.

Cohen, J. and Dupas, P. (2010). Free distribution or cost-sharing? Evidence from a randomized malaria prevention experiment. The Quarterly Journal of Economics, 125(1):1. 
Cole, S., Giné, X., Tobacman, J., Topalova, P., Townsend, R., and Vickery, J. (2013). Barriers to household risk management: Evidence from India. American Economic Journal: Applied Economics, 5(1):104-35.

Cole, S. A. and Fernando, A. (2016). Mobilizing Agricultural Advice: Technology Adoption, Diffusion and Sustainability. Harvard Business School Finance.

Collins, D., Morduch, J., Rutherford, S., and Ruthven, O. (2009). Portfolios of the poor: how the world's poor live on $\$ 2$ a day. Princeton University Press.

Conley, T. G. and Udry, C. R. (2010). Learning about a new technology: Pineapple in Ghana. American Economic Review, 100(1):35-69.

Cragg, J. G. (1971). Some statistical models for limited dependent variables with application to the demand for durable goods. Econometrica: Journal of the Econometric Society, pages 829-844.

Cramer, C., Johnston, D., Oya, C., and Sender, J. (2014). Fairtrade cooperatives in Ethiopia and Uganda: uncensored. Review of African Political Economy, 41(1):115-127.

De Janvry, A., McIntosh, C., and Sadoulet, E. (2015). Fair trade and free entry: can a disequilibrium market serve as a development tool? Review of Economics and Statistics, 97(3):567-573.

De Janvry, A. and Sadoulet, E. (2006). Making conditional cash transfer programs more efficient: designing for maximum effect of the conditionality. The World Bank Economic Review, 20(1):1-29.

De Janvry, A. and Sadoulet, E. (2019). Transforming developing country agriculture: Removing adoption constraints and promoting inclusive value chain development.

Decazy, F., Avelino, J., Guyot, B., Perriot, J. J., Pineda, C., and Cilas, C. (2003). Quality of different Honduran coffees in relation to several environments. Journal of Food Science, 68(7):2356-2361.

Deere, C. D. and Doss, C. R. (2006). The gender asset gap: What do we know and why does it matter? Feminist Economics, 12(1-2):1-50.

Doss, C. R. and Morris, M. L. (2000). How does gender affect the adoption of agricultural innovations? The case of improved maize technology in Ghana. Agricultural Economics, 25(1):27-39. 
Dragusanu, R., Giovannucci, D., and Nunn, N. (2014). The economics of fair trade. Journal of Economic Perspectives, 28(3):217-36.

Dragusanu, R. and Nunn, N. (2018). The effects of Fair Trade certification: evidence from coffee producers in Costa Rica. National Bureau of Economic Research.

Duflo, E. (2003). Grandmothers and granddaughters: old-age pensions and intrahousehold allocation in South Africa. The World Bank Economic Review, 17(1):125 .

Duflo, E., Glennerster, R., and Kremer, M. (2007). Using randomization in development economics research: A toolkit. Handbook of Development Economics, 4:3895-3962.

Duflo, E., Kremer, M., and Robinson, J. (2011). Nudging farmers to use fertilizer: Theory and experimental evidence from Kenya. American Economic Review, 101(6):2350-2390.

Dupas, P. and Robinson, J. (2013). Savings constraints and microenterprise development: Evidence from a field experiment in Kenya. American Economic Journal: Applied Economics, 5(1):163-92.

Eagly, A. H. and Chaiken, S. (1984). Cognitive theories of persuasion. Advances in Experimental Social Psychology, 17(C).

Elder, S. D., Zerriffi, H., and Le Billon, P. (2012). Effects of fair trade certification on social capital: The case of Rwandan coffee producers. World Development, 40(11):2355-2367.

Emerick, K. and Sadoulet, E. (2017). Agro-dealers and adoption of flood tolerant rice in Odisha. AEA RCT Registry.

Fafchamps, M. and Hill, R. V. (2005). Selling at the farmgate or traveling to market. American Journal of Agricultural Economics, 87(3):717-734.

Fafchamps, M., Hill, R. V., and Minten, B. (2008). Quality control in nonstaple food markets: evidence from India. Agricultural Economics, 38(3):251-266.

FAO (2008). Commodity Market Review.

Feder, G., Just, R. E., and Zilberman, D. (1985). Adoption of agricultural innovations in developing countries: A survey. Economic Development and Cultural Change, 33(2):255-298. 
Feder, G., Slade, R. H., and Lau, L. J. (1987). Does agricultural extension pay? The training and visit system in northwest India. American Journal of Agricultural Economics, 69(3):677-686.

Fiala, N. and He, X. (2017). Unitary or noncooperative intrahousehold model? Evidence from couples in Uganda. The World Bank Economic Review, 30(1):7785.

Fischer, E. and Qaim, M. (2014). Smallholder farmers and collective action: what determines the intensity of participation? Journal of Agricultural Economics, 65(3):683-702.

Fiszbein, A. and Schady, N. R. (2009). Conditional cash transfers: reducing present and future poverty. The World Bank.

Foster, A. D. and Rosenzweig, M. R. (1995). Learning by doing and learning from others: Human capital and technical change in agriculture. Journal of Political Economy, 103(6):1176-1209.

Foster, A. D. and Rosenzweig, M. R. (2010). Microeconomics of technology adoption. Annual Review of Economics, 2(1):395-424.

Gautam, M. (2000). Agricultural extension: the Kenya experience. The World Bank.

Gereffi, G. (2005). The global economy: organization, governance, and development. The Handbook of Economic Sociology, 2:160-182.

Gertler, P. (2004). Do conditional cash transfers improve child health? Evidence from PROGRESA's control randomized experiment. American Economic Review, 94(2):336-341.

Gertler, P., Heckman, J., Pinto, R., Zanolini, A., Vermeersch, C., Walker, S., Chang, S., and Grantham-McGregor, S. (2014). Labour market returns to an early childhood stimulation intervention in Jamaica. Science, 344(6187):998-1001.

Gibbon, P. and Ponte, S. (2005). Trading down: Africa, value chains, and the global economy. Temple University Press.

Glaeser, E. L., Laibson, D. I., Scheinkman, J. A., and Soutter, C. L. (2000). Measuring trust. The Quarterly Journal of Economics, 115(3):811-846.

Godtland, E. M., Sadoulet, E., Janvry, A. D., Murgai, R., and Ortiz, O. (2004). The impact of farmer field schools on knowledge and productivity: A study 
of potato farmers in the Peruvian Andes. Economic Development and Cultural Change, 53(1):63-92.

Goldstein, M. and Udry, C. (2008). The profits of power: Land rights and agricultural investment in Ghana. Journal of Political Economy, 116(6):981-1022.

Gollin, D., Morris, M., and Byerlee, D. (2005). Technology adoption in intensive post-green revolution systems. American Journal of Agricultural Economics, 87(5):1310-1316.

Goto, Y. B. and Fukunaga, E. T. (1986). Coffee: harvesting and processing for top quality coffee.

Goyal, A., Bonchi, F., and Lakshmanan, L. V. (2010). Learning influence probabilities in social network. Proceedings of the third ACM international conference on Web search and data mining.

Goyal, A. and Nash, J. (2017). Agricultural Public Spending in Africa Is Low and Inefficient.

Greene, W. H. (2009). Econometric Analysis. Prentice Hall.

Hanna, R., Mullainathan, S., and Schwartzstein, J. (2014). Learning through noticing: Theory and evidence from a field experiment. The Quarterly Journal of Economics, 129(3):1311-1353.

Heckman, J. J., Stixrud, J., and Urzua, S. (2006). The effects of cognitive and noncognitive abilities on labour market outcomes and social behaviour. Journal of Labour economics, 24(3):411-482.

Hoddinott, J. and Haddad, L. (1995). Does female income share influence household expenditures? Evidence from Cote d'Ivoire. Oxford Bulletin of Economics and Statistics, 57(1):77-96.

Hoel, J. B. (2015). Heterogeneous households: A within-subject test of asymmetric information between spouses in Kenya. Journal of Economic Behavior \& Organization, 118:123-135.

Hoerner, D., Bouguen, A., Froelich, M., and Wollni, M. (2019). The Effects of Decentralized and Video-based Extension on the Adoption of Integrated Soil Fertility Management-Experimental Evidence from Ethiopia. National Bureau of Economic Research.

Hovland, C. I. and Janis, I. L. (1959). Personality and persuasibility. 
Hovland, C. I., Janis, I. L., and Kelley, H. H. (1953). Communication and persuasion.

Hovland, C. I. and Weiss, W. (1951). The influence of source credibility on communication effectiveness. Public Opinion Quarterly, 15(4):635-650.

Humphrey, J. and Schmitz, H. (2002). How does insertion in global value chains affect upgrading in industrial clusters? Regional Studies, 36(9):1017-1027.

ICO (2019). Country Coffee Profile: Uganda. http://www.ico.org/documents/cy2018-19/icc-124-8e-profile-uganda.pdf.

ICO (2020). Trade Statistics. http://www.ico.org/prices/po-production.pdf.

Islam, M. (2014). Can a rule-of-thumb tool improve fertilizer management? Experimental evidence from Bangladesh. Harvard University.

Iversen, V., Jackson, C., Kebede, B., Munro, A., and Verschoor, A. (2011). Do spouses realise cooperative gains? Experimental evidence from rural Uganda. World Development, 39(4):569-578.

Jack, B. K. (2013). Constraints on the adoption of agricultural technologies in developing countries. Agricultural Technology Adoption Initiative.

Jakiela, P. and Ozier, O. (2016). Does Africa need a rotten kin theorem? Experimental evidence from village economies. The Review of Economic Studies, 83(1):231-268.

Jalan, J. and Somanathan, E. (2008). The importance of being informed: Experimental evidence on demand for environmental quality. Journal of Development Economics, 87(1):14-28.

Jena, P. R., Chichaibelu, B. B., Stellmacher, T., and Grote, U. (2012). The impact of coffee certification on small-scale producers' livelihoods: a case study from the Jimma Zone, Ethiopia. Agricultural Economics, 43(4):429-440.

Jensen, R. (2007). The digital provide: Information (technology), market performance, and welfare in the South Indian fisheries sector. The Quarterly Journal of Economics, 122(3):879-924.

Kabeer, N. (1999). Resources, agency, achievements: Reflections on the measurement of women's empowerment. Development and Change, 30(3):435-464. 
Karlan, D., Knight, R., and Udry, C. (2015). Consulting and capital experiments with microenterprise tailors in Ghana. Journal of Economic Behavior \& Organization, 118:281-302.

Kebede, B., Tarazona, M., Munro, A., and Verschoor, A. (2014). Intra-household efficiency: An experimental study from Ethiopia. Journal of African Economies, 23(1):105-150.

Key, N., Sadoulet, E., and de Janvry, A. (2000). Transactions costs and agricultural household supply response. American Journal of Agricultural Economics, 82(2):245-259.

Kling, J. R., Liebman, J. B., and Katz, L. F. (2007). Experimental analysis of neighborhood effects. Econometrica, 75(1):83-119.

Knight, J., Weir, S., and Woldehanna, T. (2003). The role of education in facilitating risk-taking and innovation in agriculture. The Journal of Development Studies, 39(6):1-22.

Knowler, D. and Bradshaw, B. (2007). Farmers adoption of conservation agriculture: A review and synthesis of recent research. Food policy, 32(1):25-48.

Kondylis, F., Mueller, V., and Zhu, J. (2017). Seeing is Believing? Evidence from an extension network experiment. Journal of Development Economics, 125:1-20.

Krishnan, P. and Patnam, M. (2014). Neighbors and extension agents in Ethiopia: Who matters more for technology adoption? American Journal of Agricultural Economics, 96(1):308-327.

Krumbiegel, K., Maertens, M., and Wollni, M. (2017). Modern agri-food systems, horticultural employment and women's empowerment. GlobalFood Discussion Papers.

Ksoll, C., Lilleør, H. B., Lønborg, J. H., and Rasmussen, O. D. (2016). Impact of Village Savings and Loan Associations: Evidence from a cluster randomized trial. Journal of Development Economics, 120:70-85.

Kuit, M., Jansen, D. M., and Thiet, N. V. (2004). Coffee handbook: Manual for Arabica cultivation. Tan Lam Agricultural Product Joint Stock Company.

Laajaj, R. and Macours, K. (2017). Measuring skills in developing countries. The World Bank. 
Leroy, T., Ribeyre, F., Bertrand, B., Charmetant, P., Dufour, M., Montagnon, C., and Pot, D. (2006). Genetics of coffee quality. Brazilian Journal of Plant Physiology, 18(1):229-242.

Macchiavello, R. and Miquel-Florensa, J. (2019). Buyer-Driven Upgrading in GVCs: The Sustainable Quality Program in Colombia.

Maertens, A. and Barrett, C. B. (2013). Measuring Social Networks' Effects on Agricultural Technology Adoption. American Journal of Agricultural Economics, 95(2):353-359.

Maertens, M. and Swinnen, J. F. (2009). Trade, standards, and poverty: Evidence from Senegal. World Development, 37(1):161-178.

Magruder, J. R. (2018). An assessment of experimental evidence on agricultural technology adoption in developing countries. Annual Review of Resource Economics, 10:299-316.

Mani, A. (2020). Mine, yours or ours? The efficiency of household investment decisions: An experimental approach. The World Bank Economic Review, 00(0):122.

Manser, M. and Brown, M. (1980). Marriage and household decision-making: A bargaining analysis. International Economic Review, pages 31-44.

McCroskey, J. C. and Teven, J. J. (1999). Goodwill: A reexamination of the construct and its measurement. Communications Monographs, 66(1):90-103.

McElroy, M. B. and Horney, M. J. (1981). Nash-bargained household decisions: Toward a generalization of the theory of demand. International Economic Review, pages 333-349.

McGuire, W. J. (1969). The nature of attitudes and attitude change.

McKenzie, D. (2012). Beyond baseline and follow-up: The case for more $\mathrm{T}$ in experiments. Journal of Development Economics, 99(2):210-221.

McPeak, J. G. and Doss, C. R. (2006). Are household production decisions cooperative? Evidence on pastoral migration and milk sales from northern Kenya. American Journal of Agricultural Economics, 88(3):525-541.

Meemken, E. M. and Qaim, M. (2018). Can private food standards promote gender equality in the small farm sector? Journal of Rural Studies, 58:39-51. 
Minten, B., Dereje, M., Engida, E., and Tamru, S. (2018). Tracking the quality premium of certified coffee: Evidence from Ethiopia. World Development, 101:119-132.

Minten, B., Randrianarison, L., and Swinnen, J. F. (2009). Global retail chains and poor farmers: Evidence from Madagascar. World Development, 37(11):17281741.

Mitchell, J. and Coles, C. (2011). Markets and rural poverty: Upgrading in value chains. IDRC.

Miyazaki, H. (1977). The Rat Race and Internal Market. Bell Journal of Economics, 8(2):394-418.

Mujawamariya, G., D'Haese, M., and Speelman, S. (2013). Exploring double sideselling in cooperatives, case study of four coffee cooperatives in Rwanda. Food Policy, 39:72-83.

Munro, A. (2018). Intra-Household Experiments: A Survey. Journal of Economic Surveys, 32(1):134-175.

Munro, A., Kebede, B., Tarazona-Gomez, M., and Verschoor, A. (2014). Autonomy and efficiency: An experiment on household decisions in two regions of India. Journal of the Japanese and International Economies, 33:114-133.

Munshi, K. (2004). Social learning in a heterogeneous population: technology diffusion in the Indian Green Revolution. Journal of Development Economics, 73(1):185-213.

Murnane, R. J., Willett, J. B., Duhaldeborde, Y., and Tyler, J. H. (2000). How important are the cognitive skills of teenagers in predicting subsequent earnings? Journal of Policy Analysis and Management, 19(4):547-568.

Ogutu, S. and Qaim, M. (2019). Commercialization of the Small Farm Sector and Multidimensional Poverty. World Development, 114:281-293.

Ogutu, S. O., Fongar, A., Goedecke, T., Jaeckering, L., Mwololo, H., Njuguna, M., Wollni, M., and Qaim, M. (2020). How to make farming and agricultural extension more nutrition-sensitive: evidence from a randomised controlled trial in Kenya. European Review of Agricultural Economics, 47(1):95-118.

Ouma, E., Jagwe, J., Obare, G. A., and Abele, S. (2010). Determinants of smallholder farmers' participation in banana markets in Central Africa: the role of transaction costs. Agricultural Economics, 41(2):111-122. 
Poltronieri, P. and Rossi, F. (2016). Challenges in specialty coffee processing and quality assurance. Challenges, 7(2):19.

Ponte, S. and Ewert, J. (2009). Which way is 'up' in upgrading? Trajectories of change in the value chain for South African wine. World Development, 37(10):1637-1650.

Quisumbing, A. R. and Maluccio, J. A. (2003). Resources at marriage and intrahousehold allocation: Evidence from Bangladesh, Ethiopia, Indonesia, and South Africa. Oxford Bulletin of Economics and Statistics, 65(3):283-327.

Rangel, M. A. and Thomas, D. (2005). Out of west africa: Evidence on the efficient allocation of resources within farm households. University of Chicago.

Rao, E. J. and Qaim, M. (2011). Supermarkets, farm household income, and poverty: insights from Kenya. World Development, 39(5):784-796.

Rao, E. J. and Qaim, M. (2013). Supermarkets and agricultural labour demand in Kenya: A gendered perspective. Food Policy, 38:165-176.

Raven, J. C. (1936). Mental tests used in genetic studies: The performance of related individuals on tests mainly educative and mainly reproductive. Unpublished master's thesis.

Reid, C. and Salmen, L. F. (2000). Understanding social capital: agricultural extension in Mali: trust and social cohesion.

Renn, O. and Levine, D. (1991). Credibility and trust in risk communication. Communicating Risks to the Public.

Robinson, J. (2012). Limited insurance within the household: Evidence from a field experiment in Kenya. American Economic Journal: Applied Economics, 4(4):140-164.

Ruben, R. and Fort, R. (2012). The impact of fair trade certification for coffee farmers in Peru. World Development, 40(3):570-582.

Saenger, C., Torero, M., and Qaim, M. (2014). Impact of third-party contract enforcement in agricultural markets-A field experiment in Vietnam. American Journal of Agricultural Economics, 96(4):1220-1238.

Samuelson, P. A. (1956). Social indifference curves. The Quarterly Journal of Economics, 70(1):1-22. 
Schultz, T. W. (1975). The value of the ability to deal with disequilibria. Journal of Economic Literature, 13(3):827-846.

Sellare, J., Meemken, E. M., Kouamé, C., and Qaim, M. (2020). Do Sustainability Standards Benefit Smallholder Farmers Also When Accounting For Cooperative Effects? Evidence from Cote d'Ivoire. American Journal of Agricultural Economics, 102(2):681-695.

Stiglitz, J. E. (2018). From manufacturing-led export growth to a twenty-firstcentury inclusive growth strategy: Explaining the demise of a successful growth model and what to do about it. WIDER Working Paper.

Stoian, D., Donovan, J., Fisk, J., and Muldoon, M. F. (2012). Value chain development for rural poverty reduction: a reality check and a warning. Enterprise Development and Microfinance, 23(1):54-69.

Sunding, D. and Zilberman, D. (2001). The agricultural innovation process: research and technology adoption in a changing agricultural sector. Handbook of Agricultural Economics, 1:207-261.

Suri, T. (2011). Selection and comparative advantage in technology adoption. Econometrica, 79(1):159-209.

Tobin, J. (1958). Estimation of relationships for limited dependent variables. Econometrica: Journal of the Econometric Society, pages 24-36.

UBOS (2018). Uganda Demographic and Health Survey 2016. Kampala.

UCDA (2020). Annual Reports, Kampala, Uganda. https://ugandacoffee.go.ug/.

Udry, C. (1996). Gender, agricultural production, and the theory of the household. Journal of Political Economy, 104(5):1010-1046.

Udry, C. (2011). Land tenure. The Oxford Companion to the Economics of Africa, 1.

Ulph, D. T. (1988). A general non-cooperative model of household consumption behaviour. Discussion paper.

UNIDO (2011). Industrial Development Report 2011.

Valkila, J. and Nygren, A. (2010). Impacts of FairTrade certification on coffee farmers, cooperatives, and labourers in Nicaragua. Agriculture and Human Values, 27(3):321-333. 
Van den Berg, H. and Jiggins, J. (2007). Investing in farmers the impacts of farmer field schools in relation to integrated pest management. World Development, 35(4):663-686.

Vicol, M., Neilson, J., Hartatri, D. F. S., and Cooper, P. (2018). Upgrading for whom? Relationship coffee, value chain interventions and rural development in Indonesia. World Development, 110:26-37.

Wasserman, G. S., Bradbury, A., Cruz, T., and Penson, S. (2000). Coffee. KirkOthmer Encyclopedia of Chemical Technology, pages 1-22.

Webber, C. M. and Labaste, P. (2009). Building competitiveness in Africa's agriculture: a guide to value chain concepts and applications. The World Bank.

Wilson, C. (1977). A model of Insurance Markets with Incomplete Information. Journal of Economic Theory, 16:167-207.

Wollni, M. and Zeller, M. (2007). Do farmers benefit from participating in specialty markets and cooperatives? The case of coffee marketing in Costa Rica. Agricultural Economics, 37(23):243-248.

Wooldridge, J. M. (2010). Econometric analysis of cross section and panel data. MIT press.

World Bank (2007). World development report 2008: Agriculture for development. World Bank.

World Bank (2020). Poverty and Equity Database. http://povertydata.worldbank.org.

Wozniak, G. D. (1993). Joint information acquisition and new technology adoption: Late versus early adoption. Review of Economics and Statistics, 75(3):438445. 